Portland State University

PDXScholar

Spring 6-6-2018

\title{
The Dispute Over the Commons: Seed and Food Sovereignty as Decommodification in Chiapas, Mexico
}

Carol Frances Hernández Rodríguez

Portland State University

Follow this and additional works at: https://pdxscholar.library.pdx.edu/open_access_etds

Part of the Sociology Commons, and the Sustainability Commons Let us know how access to this document benefits you.

\section{Recommended Citation}

Hernández Rodríguez, Carol Frances, "The Dispute Over the Commons: Seed and Food Sovereignty as Decommodification in Chiapas, Mexico" (2018). Dissertations and Theses. Paper 4403.

https://doi.org/10.15760/etd.6287

This Dissertation is brought to you for free and open access. It has been accepted for inclusion in Dissertations and Theses by an authorized administrator of PDXScholar. Please contact us if we can make this document more accessible: pdxscholar@pdx.edu. 
The Dispute Over the Commons:

Seed and Food Sovereignty as Decommodification in Chiapas, Mexico

by

Carol Frances Hernández Rodríguez

A dissertation submitted in partial fulfillment of the requirements for the degree of

\author{
Doctor of Philosophy \\ in \\ Sociology
}

\author{
Dissertation Committee: \\ Daniel Jaffee, Chair \\ Michele Gamburd \\ Alex Stepick \\ José Padín
}

Portland State University

2018 
C 2018 Carol Frances Hernández Rodríguez 


\begin{abstract}
Seeds have become one of the most contested resources in our society. Control over seeds has intensified under neoliberalism, and today four large multinational corporations control approximately 70 percent of the global seed market. In response to this concentration of corporate power, an international social movement has emerged around the concept of seed sovereignty, which reclaims seeds and biodiversity as commons and public goods. This study examines the relationship between the global dynamics of commodification and enclosure of seeds, and the seed sovereignty countermovement for decommodification. I approach this analysis through an ethnographic case study of one local seed sovereignty movement, in the indigenous central region of Chiapas, in southern Mexico. I spent eight months between 2015 and 2016 conducting field research and documenting the development of the Guardians of Mother Earth and Seeds project, a local initiative focused on seed and food sovereignty that was initiated in 2015 by DESMI, the most established NGO working in this region. It encompasses 25 peasant communities - 22 indigenous and 3 mestizo - from the Los Altos, Norte-Tulijá, and Los Llanos regions of Chiapas. I also collected data from 31 other communities in the region involved to varying degrees with this agenda of seed and food sovereignty. This study incorporates both communities affiliated with the Zapatista Army of National Liberation (EZLN) and non-Zapatista communities.

Three research questions guide this dissertation: (1) How do the increasing industrialization and commodification of seed systems and agriculture affect peasant communities in Chiapas?; (2) How is the local seed and food sovereignty countermovement responding to those processes of commodification?; and (3) How does
\end{abstract}


this case study contribute to understanding the relationship between capital's tendency to enclose the commons and the protective countermovements that attempt to resist such market encroachments?

This study found that the development of industrial agriculture and the commodification of seeds at the global and national scales have implied neither the displacement of these communities' native seeds by commercial seeds, nor their privatization - two of the most frequent potential risks denounced by representatives of the national and international seed sovereignty movement. Instead, the main impact of industrial agriculture and Green Revolution policies in the study region has been the chemicalization of peasant agriculture, with attendant negative impacts on the environment and human health. I also found that subsistence agriculture - the main mechanism through which native seeds are reproduced within communities-is undergoing a process of severe deterioration, which partially responds to the neoliberal dismantling of governmental institutions and programs supporting peasant agriculture. A key finding of this research is that the deterioration of subsistence agriculture is the main risk that the neoliberal restructuring of agriculture poses to native seeds. In response to these developments, communities in this study have embraced a project of decommodification focused on enhancing and expanding their subsistence agriculture. This project encompasses agroecology, food production collectives, and initiatives for agro-biodiversity conservation and ecological restoration. I argue that this project contributes to the decommodification of subsistence agriculture in the region, primarily by strengthening the non-commodified structures that are essential for these communities social reproduction. 
To my mother, Frances Rodriguez Vangort, whose unconditional love has allowed me to flourish

To Greta, who already has in her child heart the seeds of compassion and rebellion

To Elena, a feminist Zapatista woman, who unconditionally opened to me her heart and the Zapatista world 


\section{ACKNOWLEDGMENTS}

I am grateful for everyone who is caring about the world and working on moving things, bit by bit, away from devastation and toward unpredictable possibilities for life going on in general and in all its particularity.

Alexis Shotwell

Against Purity (2016)

This dissertation is the most significant teamwork I have participated in. It reflects the commitment, effort, insight, and love of several people whose lives are dedicated to creating a better world for all of us. I feel sadness at not being able, due to confidentiality issues, to write here the real names of the people I worked closely with in Chiapas. It is ironic that those who are the protagonists of ethnographies have to live under anonymity as scholars narrate their lives! At the same time, I agree with the Zapatista precept of the collective human being: we are all the same people working together to build a better world and, therefore, individual identities are somewhat meaningless. Having said that, I want to thank Elena, Sebastian, Mariano, Rosario, Josefa, Pedro, and Teodoro, all of them people from DESMI. I am really grateful for their unconditional support: from opening to me the doors of their organization and the communities and people they work with, to sharing with me many of their personal stories in "the struggle," and to always trusting in my work and making me feel welcome in all the activities I participated with them. Elena, Mariano, and Sebastian deserve my deepest and heartfelt gratitude. Many days during my fieldwork I went to bed with my heart full of happiness and excitement for having them in my life. 
This project would not have been possible without all the people from the communities I worked with. I will always remember their huge smiles when, after apologizing for not been able to feed me with meat or eggs, I answered that I was vegan and that my daily meals, even here in Portland or in Mexico City, essentially consisted of beans, tortillas, and some vegetables, just like them. Many people would laugh after saying something like "you are one of us, now you can come and live here." In communities where food is very limited, as in the case of all the communities that participated in this research, having lunch together is a particularly important activity that people share with enthusiasm. Food is never taken for granted and every meal is a small celebration. I feel deep gratitude for all the food and time peasants shared with me.

I also want to thank the people from the Cideci-Unitierra-the Zapatista University in San Cristóbal de las Casas. The political economy seminars and conferences I was able to attend there helped me to better understand and contextualize the work of DESMI and the EZLN. I recognize this as one of the most intellectually challenging spaces in which I have participated in my entire academic life.

There are two other people from Chiapas who have immensely contributed to this dissertation and my personal life: Juan, a Zapatista Tseltal, and the researcher Hugo Perales from Ecosur. Both of them have become two of my most beloved friends. This dissertation would be totally different without all the information and insight they shared with me. In a way, they helped me to trace the contours of this dissertation and make sense of much of the information I gathered during my fieldwork. Hugo Perales also read and commented on several chapter drafts. Particularly useful have been our countless 
conversations by Skype. From him I have learned to love maize and all of the culture and history that surrounds it.

I do not have enough words to thank my adviser, Daniel Jaffee. He has done what only the best teachers are able to do: challenging students' capacities to the limit at the same time as meticulously teaching them the craft of doing good research. He also encouraged me to learn how to be critical at the same time as remaining committed to the social causes and movements I believe in, in this case the Zapatista movement. Daniel also read, edited, and commented on a weekly basis on every single page of this dissertation - I am grateful that it was never a big issue, or a disappointment for him, that on several weeks I had to put in the garbage many or all of the pages I had written during the previous days. The only way I can pay back what he has given me is replicating his example with my own students. I also want to thank José Padín, Alex Stepick, and Michele Gamburd - all of them members of my doctoral committee from Portland State University (PSU) — and Jack Kloppenburg (University of Wisconsin, Madison) for their intellectual and emotional contributions to this research.

My doctoral studies in the United States would have been impossible without the full four-year scholarship I received from Conacyt and the Mexican government. During the last two years of my Ph.D. I also benefited from the PSU International Student Retention Scholarship, and I feel privileged for all the support I have received from the PSU International Student Life team. Particularly important in my life have been Jill Townley, Yoko Honda, Rachel Krueger, and Alyssa Koida. I also want to recognize here all the support and friendship from Jarrod Dunham from the PSU Writing Center, who always read my drafts with enthusiasm and interest. 
I am especially grateful to my mother for her unconditional love and support, and also for teaching me to identify beauty and possibilities in everything. My commitment to social and environmental justice and my love for animals also come from her. I am aware that my long-term stay far from home has been very difficult for my mother and all my family, including my four cats. My youngest brother, Luis, has been particularly supportive during this process, and he has always encouraged me to enjoy every single part of it. Cesar has also been an unconditional support during my entire academic carrier. Finally, I want to thank my brother Paul and my sister-in-law Yolanda for their love and patience. I know I have missed all of the birthdays of my niece and nephews, and I am really sorry for not having been present during their first years of life. This dissertation is dedicated to them: Greta, Alger, and Arjan. Your presence in my life makes me happy. 


\section{TABLE OF CONTENTS}

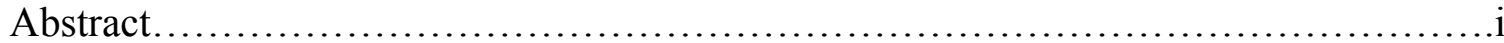

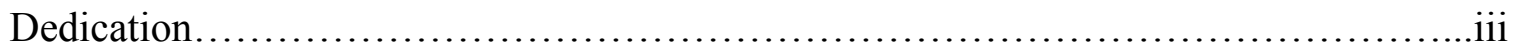

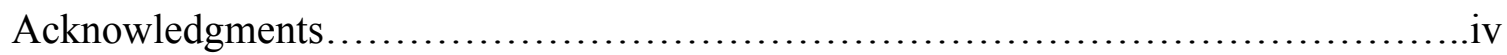

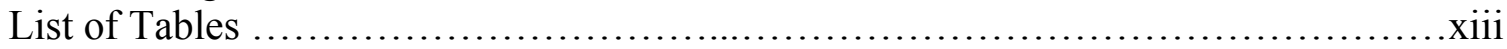

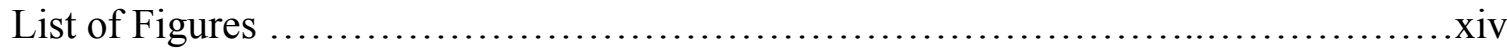

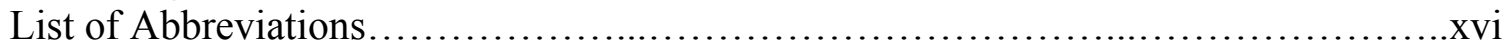

Glossary of Spanish Terms.....................................................

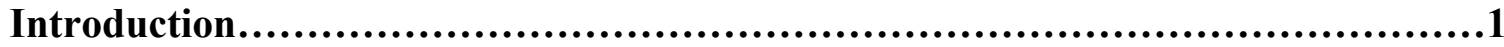

Chapter One: Capital Accumulation, the Commons, Seed and Food Sovereignty, and Decommodification.............................................................18

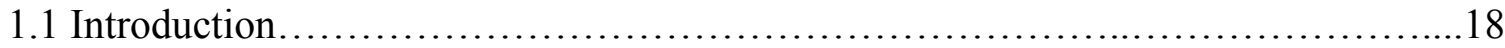

1.2 Primitive Accumulation and Imperialism...................................21

1.2.1 Primitive Accumulation: an Enduring Feature of Capitalism?.........................21

1.2.2 The New Imperialism and Accumulation by Dispossession............................23

1.2.3 Imperialism and Crises of Capital Overaccumulation........................26

1.2.4 Seed Commodification and Accumulation by Dispossession..................27

1.3 Commodification, Decommodification, and Seeds.................................28

1.3.1 Commodification and Non-Commodified Production........................28

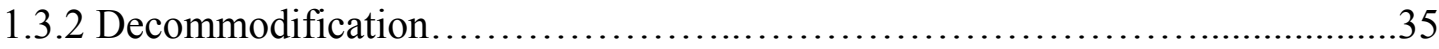

1.3.3 Decommodification and Common Pool Resources.............................37

1.3.3.1 The Tragedy of the Commons and Privatization.......................37

1.3.3.2 Fictitious Commodities, The Double Movement, and

Decommodification..............................................

1.3.3.3 Alternative Arrangements for Governing CPR .....................42

1.3.3.4 Governing Common Resources at Global Scale: Limits and

Possibilities..................................................45

1.4 Food and Seed Sovereignty in a Neoliberal Context.............................46

1.4.1 Food Regimes and Neoliberal Globalization: Corporate Power, Green

Neoliberalism, and Social Movements......................................47

1.4.2 Neoliberalizing Agriculture and Food....................................... 51

1.4.3 The Peasant Alternative: Food Sovereignty...............................54

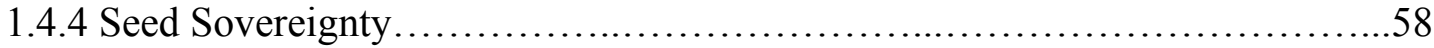

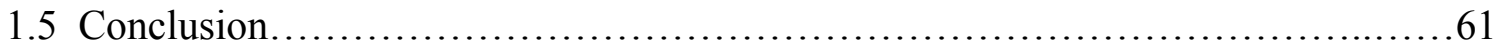




\section{Chapter Two: From the Plantation Economy to the Neoliberal "Modernization" of}

Mexican Agriculture.............................................................63

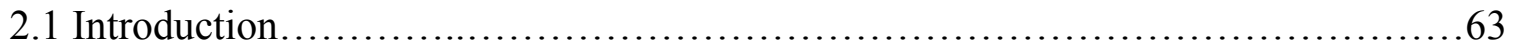

2.2 The Finca Economy: Accumulation by Dispossession, Land Concentration, and

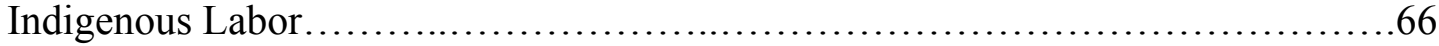

2.3 The Post-revolutionary Agriculture System: Agrarian Reform and Campesino Agriculture............................................................ 72

2.3.1 Lázaro Cárdenas: the Revolution of the Indios in Chiapas....................76

2.3.2 Chiapas During and After Cárdenas: Commercial Agriculture, Indigenous Labor, and Corporatist Control....................................... 80

2.4 The Neoliberalization of Mexican Agriculture.................................... 83

2.4.1 The Limits of Peasant Agriculture........................................83

2.4.2 The Crisis of Mexican Agriculture....................................... 87

2.4.3 The Rise of Neoliberalism...........................................91

2.4.4 The World Bank and the "Modernization" of Mexican Agriculture.............97

2.4.5 "Maize is Not More Business": NAFTA, Food Dependency, and Peasant Agriculture.........................................................98

2.4.6 "NAFTA is a Death Certificate for the Indian Peoples of Mexico": The Zapatista Agrarian Reform............................................103

\section{Chapter Three: Chiapas: Poverty, Low-Intensity War, and Zapatista}

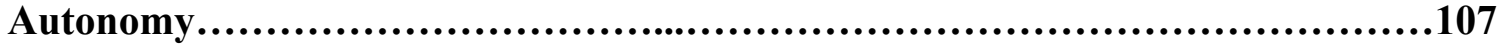

3.1 Introduction: A Postcard from the Central Plaza of San Cristóbal de las Casas,

Chiapas.............................................................. 107

3.2 My First Encounter with Zapatista Communities.............................110

3.3 Poverty, Ethnicity, and Gender......................................... 113

3.4 New Geographies: Zapatista Autonomy and Low-Intensity War...................122

3.4.1 The Setting in Context................................................. 122

3.4.2 Resistance, Autonomy, and Counter-Insurgency........................ 127

3.4.3 Women and the EZLN.............................................. 132

3.4.4 Zapatista Autonomous Institutions...................................... 136

3.5 Conclusion.............................................................. 142 


\section{Chapter Four: "We Are the People of Maize": Seed Sovereignty and the Battle for}

the Commons.........................................................................146

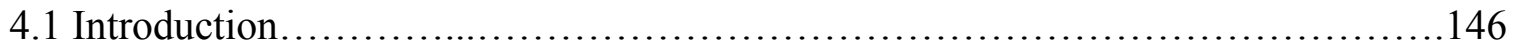

4.2 Spiritual, Material, and Cultural Meanings of Native Seed Systems................149

4.2.1 Sacred Seeds: Mayan Theology and The Mayan Altar Ceremony..............149

4.2.1.2 Strategic Essentialism?...............................................................153

4.2.2 Native Maize, The Milpa System, and Subsistence Agriculture...............159

4.2.3 Community Seed Systems: Seed Inheritance, Exchange, and Intellectual Property Rights.......................................................166

4.2.4 Threats to Seeds.................................................. 174

4.3 Industrial Agriculture and Seeds........................................... 178

4.3.1 The Green Revolution in Context: Industrial Seeds and Food

Sovereignty. .................................................... 178

4.3.2 The Green Revolution's Countermovements: Anti-GMOs and Seed Sovereignty................................................. 184

4.3.3 Beyond Industrial Seeds: Agrochemicals, Labor, and Environmental

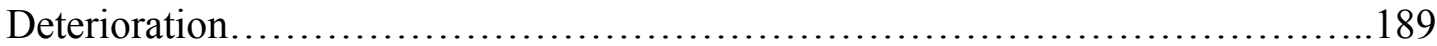

4.3.3.1 The Free Family Labor Dilemma............................... 190

4.3.3.2 Unexpected Consequences: Environmental, Health, and Dietary

Deterioration............................................... 195

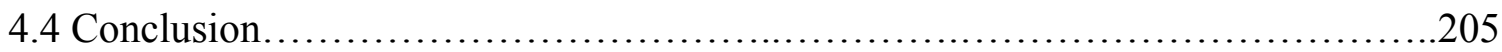

Chapter Five: "Without Food There is No Resistance": Seed and Food Sovereignty as Decommodification............................................................209

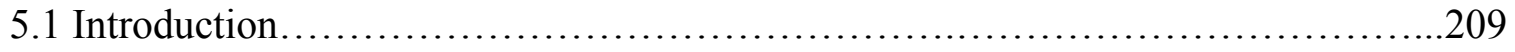

5.2 Almost 50 Years on the Ground: DESMI, Solidarity Economy, and Indigenous

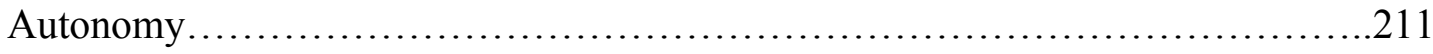

5.3 The Beginnings: Liberation Theology, the Diocese of San Cristobal, and the Guerrilla Movement...................................................2 216

5.4 The Consolidation: Agroecology, Food Security, and the Zapatista Project.........224

5.5 Raising an Environmental Consciousness................................230

5.6 Once Again: DESMI, the Pastoral of Mother Earth, and Seed Sovereignty in NonZapatista Communities.................................................236 
5.7 Conclusion

Chapter Six: Building Seed Sovereignty: The Guardians of Mother Earth and Seeds Project.....................................................................244

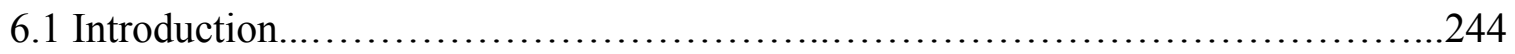

6.2 Fencing off Non-Market Spheres From Market Encroachments: Understanding Informal Seed Systems as Commons...........................................248

6.3 Knowing and Preserving the Commons: Communities' Seed Inventories and Seed Banks.

6.4 Making the Connection: Organic Production, Food Security, and Seed

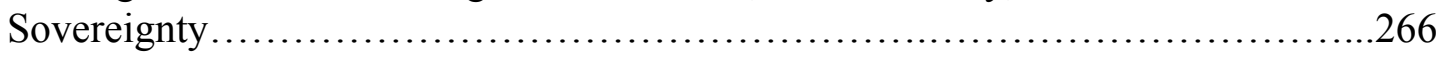

6.5 Agroecology and War: Limits and Opportunities...............................2272

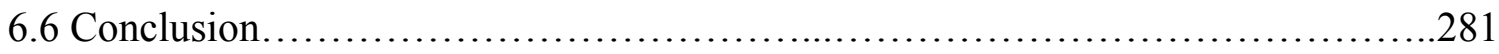

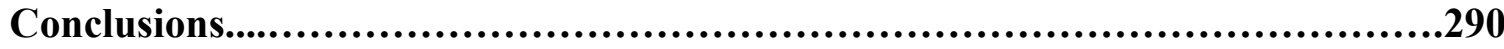

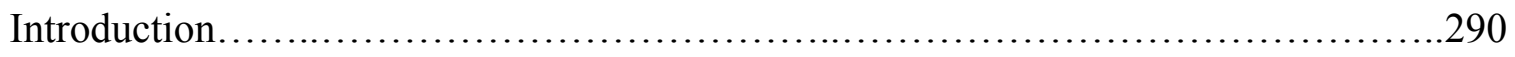

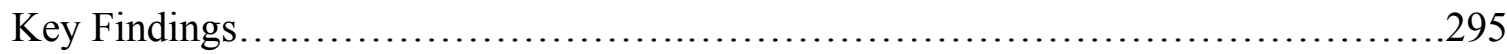

Commodification and Deterioration of Subsistence Agriculture....................295

Seed and Food Sovereignty as Decommodification...................................297

Seed Privatization and Peasant Agriculture...........................................300

The Political Discourses of Seed Sovereignty .......................................304

Contextualizing Food and Seed Sovereignty in the Zapatista Project of Indigenous

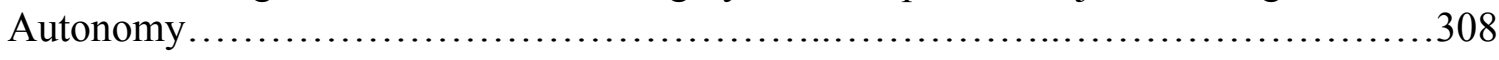

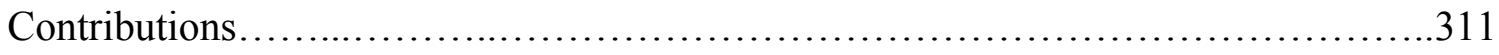

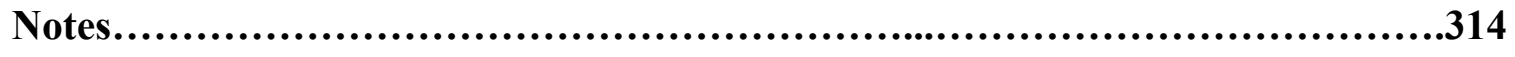

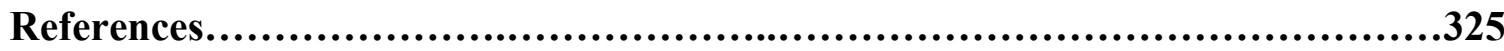

Appendix: Research Methods.....................................................349

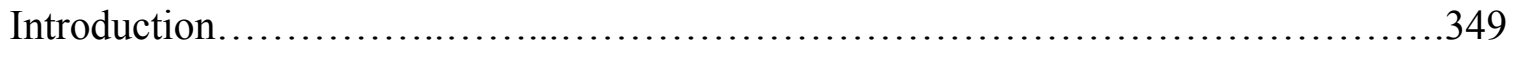




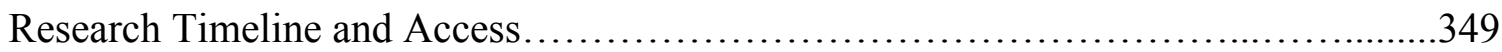

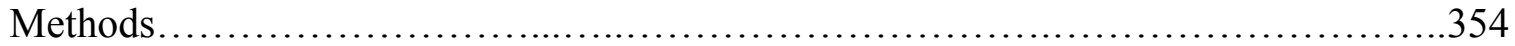

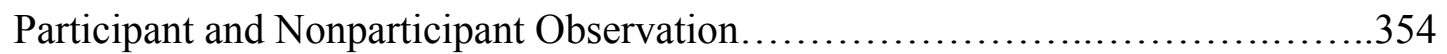

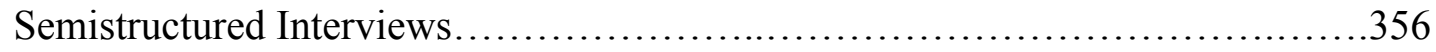

Interviews with Community Members.....................................358

Interviews with Members of the Pastoral of the Diocese of San Cristobal...359

Interviews with Staff Members of DESMI and Other Local Organizations...360

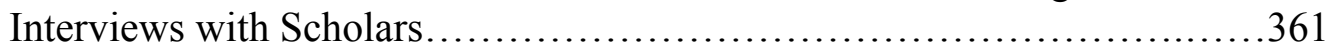

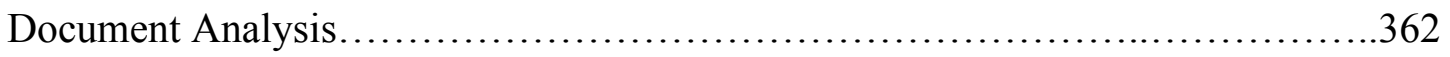

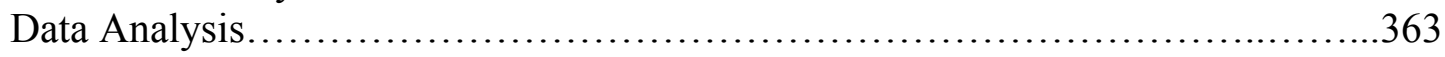

Reflections on Methods and Limitations of Research................................ 363

A Note on Positionality...................................................... 368 


\section{LIST OF TABLES}

\section{Chapter Three}

1. Area of research: regions, municipalities, and ethnicity........................116

2. Demographic data: social marginalization and ethnicity ........................119

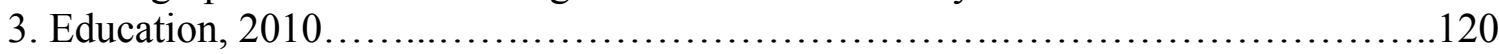

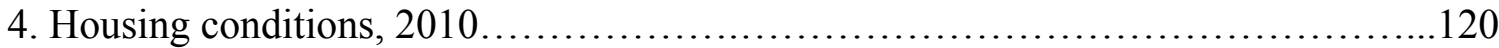

5. Ejidos and Comunidades Agrarias, ejidatarios and comuneros by gender, 2007.....121

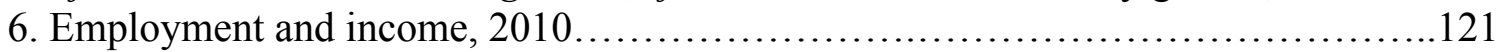

7. Study region: characteristics of communities................................. 123

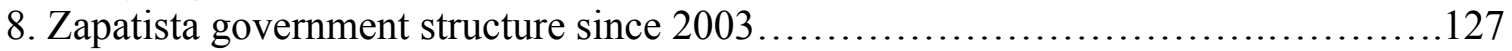

\section{Chapter Five}

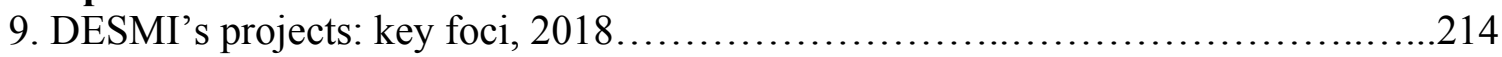

10. DESMI's projects in Zapatista and non-Zapatista communities, $2018 \ldots \ldots \ldots \ldots \ldots . .215$

11. Key events in the development of DESMI and the EZLN: 1968-2017.............241

\section{Chapter Six}

12. DESMI's projects in non-Zapatista communities participating in the Guardians of Mother Earth and Seeds project.............................................246 


\section{LIST OF FIGURES}

\section{Chapter Three}

1. Maps of Chiapas, Mexico.

2. Maps of main indigenous groups in Chiapas, Human Development Index at the municipal level, and area of study .......................................... 114

3. Maps of communal land tenure in Mexico and Chiapas: Ejidos and Comunidades Agrarias .................................................................. 124

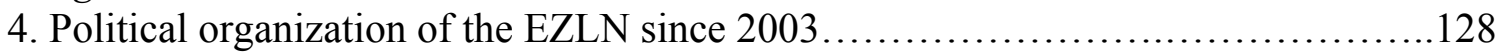

5. Maps of the area of conflict: Zapatista communities, police and military positions, and paramilitary groups.................................................. 130

\section{Chapter Four}

6. The Mayan altar ceremony.............................................. 152

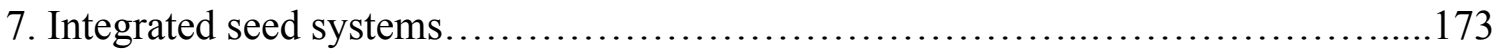

8. Types of exchanges and seed types....................................... 174

\section{Chapter Five}

9. Map of DESMI's area of work, by regions and municipalities, $2018 \ldots \ldots \ldots \ldots \ldots .213$

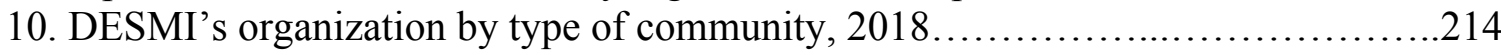

11. Map of the Diocese of San Cristóbal de las Casas and its seven regions................217

\section{Chapter Six}

12. Communities participating in DESMI's Guardians of Mother Earth and Seeds project.............................................................245

13. What do we produce? Where do our seeds come from? "Talking Maps,"

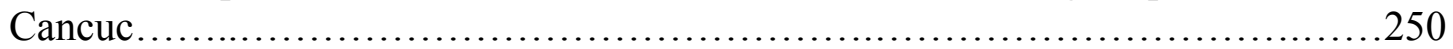

14. Introductory workshop with mestiza women: The Capitalist Hydra.................253

15. The Vandana Shiva cooperative society of agroecological producers, in the Cideci..............................................................255

16. Peasants from Cancuc identify some strategies they can assume in order to protect their seeds.....................................................257

17. Mothers and children in search of native seeds, Tumbalá.........................260

18. Women with native peanuts, Tumbalá......................................260

19. Youths writing down seed names, Tumbalá....................................260

20. Lak Pakobal ("Our Seeds," in Ch'ol): the final inventory, Tumbalá...............261

21. Snahil Kawal Jts'unubtik (“Our Community Seed House," in Tseltal): the making of a seed bank, Cancuc..................................................264

22. "The land belongs to those who defend it. Community Adherent to the Sixth

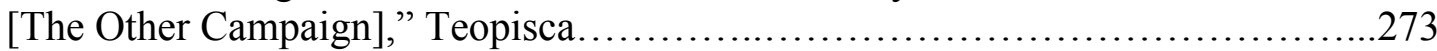

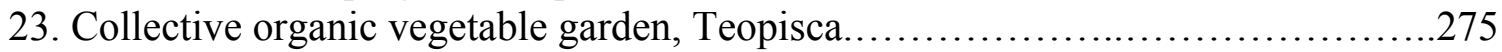

24. War, drought, and food insecurity: food truck in Venustiano Carranza..............278

25. Chicken-raising cooperatives, Venustiano Carranza and Teopisca. .................278

26. Molasses-production collective, Venustiano Caranza..........................279

27. Emiliano Zapata, major leader of the Mexican Revolution of 1910: "The land 
belongs to those who work it," Teopisca........................................280 28. Lekil Kuxlejal-Ich 'el ta muk': the process of building a dignified and harmonious

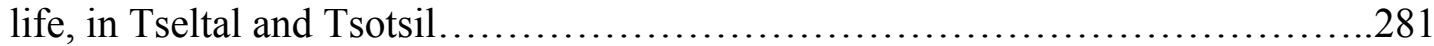




\section{LIST OF ABBREVIATIONS}

CCRI-CG: EZLN's Clandestine Revolutionary Indigenous Committee General Command.

CECCAM: Center for Studies of Change in the Mexican Countryside, located in San Cristóbal de las Casas, Chiapas.

CNI: $\quad$ Congreso Nacional Indígena (Mexican National Indigenous Congress).

CONASUPO: National Company of Popular Subsistence, a Mexican governmental agency that was privatized in the 1990s.

DESMI: Desarrollo Económico y Social de los Mexicanos Indígenas (Social and Economic Development for Indigenous Mexicans), a local grassroots organization from Chiapas.

ECOSUR: El Colegio de la Frontera Sur (College of the Southern Border), located in San Cristóbal de las Casas, Chiapas.

EZLN: $\quad$ Ejército Zapatista de Liberación Nacional (Zapatista Army of National Liberation). Founded in 1983 in the Lacandona rainforest in Chiapas, Mexico, it took up arms and declared war on the Mexican government on January $1^{\text {st }}, 1994$, the same day that NAFTA came into force.

FAO: $\quad$ United Nations Food and Agriculture Organization.

FERTIMEX: Mexican Fertilizer Company, a governmental agency that was privatized in the 1990s.

FLN: $\quad$ Fuerzas de Liberación Nacional (National Liberation Forces), a clandestine group formed by students and professors in the Northern state of Monterrey in 1969. In 1972 it established the first guerrilla nucleus Emiliano Zapata in the Lacandon rainforest in Chiapas, Mexico. The EZLN was born from FLN.

FRAYBA: Human Rights Center Bartolome de las Casas, located in San Cristóbal de las Casas.

GATT: General Agreement on Tariffs and Trade, the precedent organization of the WTO.

GMO: Genetically Modified Organism.

HDI: Human Development Index. 
HYVs or MV: High-Yielding crop varieties, or Modern Varieties.

IMF: International Monetary Fund.

JBG: Juntas de Buen Gobierno, EZLN's Good Government Councils.

LIW: $\quad$ Low-intensity war.

MAREZ: EZLN's autonomous municipalities or councils.

NAFTA: $\quad$ North America Free Trade Agreement, signed by Mexico, the U.S., and Canada. The agreement came into force on January $1^{\text {st }}, 1994$.

OPEC: $\quad$ Organization of Petroleum Exporting Countries.

PRONASE: National Seed Producing Company, a Mexican governmental agency that was privatized in the 1990s.

SAM: $\quad$ Mexican Food System Program.

U.N.: $\quad$ United Nations.

UPOV: International Union for the Protection of Plant Varieties.

WTO: World Trade Organization. 


\section{GLOSSARY OF SPANISH TERMS}

Base de apoyo: EZLN's support base.

Campesino: Peasant.

Comunero: A member of an indigenous community with rights recognized by the Mexican government to the usufruct of an individual plot of land for agriculture, to access the collective natural resources of the community, such as forests and water resources, and to participate in the community assembly, the most important internal governmental organism.

Comunidad agraria or comunidad indigena: Collective land holdings owned by indigenous communities. These holdings embody federal recognition of the preexisting land claims of indigenous peoples, many of whom hold titles granted by the Spanish viceroys in the sixteenth and seventeenth centuries.

Coyote: Local money lender or intermediary merchant. This term also refers to a person who, in exchange for money, helps migrants without documents to cross the international border into the U.S.

Ejidatario: A member of an ejido with rights recognized by the Mexican government to the usufruct of an individual plot of land for agriculture, to access the collective natural resources of the ejido, such as forests and water resources, and to participate in the community assembly, the most important internal governmental organism.

Ejido: Collective land holdings granted by the Mexican government to a group of peasant families; most ejidos are inhabited by mestizo people.

Finca or Hacienda: Plantation.

Insurgentes: Insurgents of the EZLN.

Jornalero: Agricultural laborer.

Juntas de Buen Gobierno: EZLN's Good Government Councils.

La Resistencia: Resistance, EZLN's political practice of resistance against the Mexican government. It consists of rejecting any federal or state government project, subsidy, and, frequently, even basic services.

Latifundio: Large landholdings of over 1,000 hectares or 2,471 acres.

Latifundista or terrateniente: A latifundio's owner. 
Mal gobierno: Bad government, a term used by the EZLN to refer to the Mexican government.

Maiz: Corn. Mesoamerica, and particularly Mexico, is the center of origin of this crop, which was domesticated by Mesoamerican peoples roughly 9,000 years ago.

Mestizo or ladino: People of mixed Spanish and indigenous heritage who are the dominant ethnic group in Mexico.

Milicianos: Members of the EZLN's militias.

Milpa: Traditional maize field consisting of maize intercropped with other species, commonly beans, squash, tomatoes, and chili. This is a pre-Columbian agricultural system that was developed by Mesoamerican peoples about 2,000 years ago.

Patrón: Landowner.

Peón: Serf.

Peón acasillado: Permanent laborer who lived in the fincas.

Porfiriato: The regime of the Mexican dictator Porfirio Díaz, lasting from 1876 to 1910.

Selva Lacandona: Lacandon rainforest, located in the southeast of Chiapas.

Solar: A vegetable garden located in a household's patio. 


\section{INTRODUCTION}

Freedom for seeds

No more slavery

No more suicides and cruelty

Stand up together, be ready

Seeds of freedom

Spread in the air of society

Gardens of hope growing slowly

Everywhere just to share

Last chance to save humanity

Seeds of freedom

Time has come

Manu Chao, "Seeds of Freedom” (2017)

Monsanto wants to steal our seeds.

Ch'ol indigenous woman, Chiapas (2016)

Today, at an unprecedented moment in the history of agriculture, four large multinational corporations control nearly three-quarters of the global market for seeds and agrochemicals. They are the German firm Bayer, which in 2017 acquired Monsanto; the American chemical firm DowDuPont; ChemChina, which recently purchased the seed giant Syngenta; and the German chemical firm BASF (Bonny 2017: 9, 11). The magnitude and speed of this corporate concentration have been dramatic. In 1985, the top four companies accounted for only eight percent of the total commercial market for seeds and agrochemicals. This situation began to change in the 1990s, as public research and breeding institutions were privatized or dismantled, the regime of intellectual property rights (IPR) over germplasm was consolidated, nations in the global South liberalized their agricultural sectors, and genetically modified organisms (GMOs) spread around the world in the form of seeds, crops, and other products. First sold commercially in 1994, GMOs now constitute one third of the global market for seeds (Bonny 2017: 8). By 2000, 
the top four firms controlled 18 percent of the seed and agrochemical market, increasing to 30 percent in 2005,51 percent in 2016 , and 70 percent in 2018 , as companies continued to merge (Bonny 2017: 9, 16). Nowadays, seed, agriculture, and food systems all around the world are attached to some degree to these four giant agrifood corporations.

This rapid concentration of corporate power over agriculture has triggered the rise of an international countermovement, which has coalesced in part around the concept of food sovereignty and, more recently, of seed sovereignty. The origins of this countermovement can be traced back to the late 1970s with the emergence of the global anti-biotechnology movement (Schurman and Munro 2010). Since its origins, activists and scientists from both the global North and South have called attention to the ecological, social, and ethical implications of genetic engineering, Green Revolution agricultural policies implemented in the global South, and the increasing corporate power over seeds and genetic resources (Kloppenburg 2004, Schurman and Munro 2010, Shiva 1991). In 1993, in response to neoliberal reforms increasingly affecting peasant agriculture worldwide, the international peasant movement La Via Campesina (LVC) - a transnational network encompassing thousands of peasant organizations and millions of members worldwide - was founded under the banner of food sovereignty (LVC 2018a, Martínez-Torres and Rosset 2010, McMichael 2014). According to LVC, "food sovereignty is the right of peoples to healthy and ecologically appropriate food produced through ecologically sound and sustainable methods, and their right to define their own food and agriculture systems" (LVC 2018a). 
In recent years, the anti-biotechnology and food sovereignty movements have also begun to converge around the idea of seed sovereignty, which opposes increasing corporate power over seeds, agriculture, and food systems (Kloppenburg 2014, McMichael 2014). According to the Indian activist Vandana Shiva, "seed sovereignty reclaims seeds and biodiversity as commons and public good" (2018). On a global scale, this novel movement has taken the form of a stance against GMOs, as well as resistance to the international regime of IPR over germplasm, the widespread use of agrochemicals in agriculture, the spread of agribusiness and the displacement of peasant agriculture, and the liberalization of seed, agriculture, and food systems under "free trade" treaties. In synthesis, the idea of seed sovereignty contests the neoliberal model of industrial agriculture that has been promoted by the biotechnology and food industries, as well as by international institutions and many governments (Kloppenburg 2014, LVC 2013, 2018b, Navdanya 2018a).

These developments reflect the growing contention that exists between what Kloppenburg calls corporate sovereignty over the seed, and people's seed sovereignty (2014: 1232). Underlying this dichotomy are two diametrically opposed paradigms of agriculture, production, and food security: on one hand, the neoliberal model of industrial agriculture, and, on the other, the model of peasant food sovereignty advocated by LVC and supported by environmental and peasant movements worldwide (Bello 2009, McMichael 2014).

However, the concept of peasant food sovereignty, as defined by LVC, goes beyond merely food security. Peasant food sovereignty is also a question of power. For peasant communities, the idea of food sovereignty encompasses food security, control 
over land and seeds, and collective autonomy for defining their own systems of production, exchange, consumption, and the terms of wealth distribution (LVC 2018a). Each of these principles is in contradiction to capital's global market-driven vision and rules for organizing production, community, and even life itself (Desmarais 2015, Martínez-Torres and Rosset 2010, McMichael 2016a, 2014, Polanyi 1944, Rosset and Martínez-Torres 2012, van der Ploeg 2010).

Is the international food sovereignty movement a strong enough force to meaningfully challenge the neoliberal character of the contemporary agri-food system? The answer may depend on how deeply the food sovereignty movement engages itself in the construction of mechanisms aimed at re-establishing social control over the economy (Polanyi 1944), and whether it is able to generate systemic strength and power through the creation of global networks and strategic relationships with other actors, including different social movements, civil society initiatives, and even governments.

Seed sovereignty is one of the newest areas of the global food sovereignty movement. It has gained relevance as GMO crops have spread globally and corporate power over seeds has consolidated. It is in this context that developing a clear understanding of what seed sovereignty means in practice, not merely in theory, is especially important. While a substantial interdisciplinary body of scholarship has emerged over the past decade on food sovereignty, very little scholarly work presently exists on seed sovereignty, and virtually no in-depth empirical studies have been published. This study aims to address that gap.

In order to analyze the seed sovereignty movement, it is also important to understand the specific mechanisms and processes by which capital has been able to 
erode many of the barriers that have obstructed the commodification and enclosure of seeds and agriculture. One useful way to approach this analysis is as a tension between the dynamics of commodification and decommodification. That is, the relationship between capital's tendency to commodify the conditions, activities, and means of human existence in pursuit of profit and accumulation, (Glassman 2006); and the emergence, in response, of social countermovements that attempt to resist such capital's expansion and, using Karl Polanyi's language, to reembed the economy in the fabrics of society (1944: 71-80). In this research I propose to conceptualize seed sovereignty as a decommodification countermovement that aims to limit and reverse the process of enclosure of seeds and agriculture.

How is this relationship between commodification and decommodification concretized in local space? How do small-scale peasant communities perceive and respond to the global dynamics of capital accumulation that threaten peasant agriculture and seeds? How do local agendas of seed sovereignty relate to the broader ideologies, goals, and strategies of the global seed and food sovereignty movement? How are national and international political discourses translated into concrete projects of decommodification? This study approaches these and other questions empirically through an ethnographic case study of a regional seed sovereignty movement in practice.

\section{Overview of this Study}

The setting of this study is the indigenous central region of Chiapas, Mexico's southernmost state, where I spent eight months between August 2015 and March 2016 conducting field research, as well as working as a full-time volunteer with the local nongovernmental organization DESMI (Social and Economic Development for Indigenous 
Mexicans). DESMI was my main point of access to indigenous communities and other local organizations, and I benefited immensely from the trust that this organization has built over almost fifty years of consistent work in the region. As I will discuss in depth later in the dissertation, DESMI is the key actor that has made possible the expansion of the agenda of seed sovereignty across this region.

DESMI is one of the oldest and most important grassroots organizations in Chiapas. Founded in 1969 by Bishop Samuel Ruiz - an adherent of liberation theology who came to be much beloved by indigenous communities in the state-DESMI was born as a lay civil society organization focused on building a "solidarity economy" model among Tseltal, Tsotsil, and Ch'ol indigenous communities. Since its origins, DESMI has played a crucial role in the development of the project of indigenous autonomy in the region. The uprising of the indigenous Zapatista Army of National Liberation (EZLN) in 1994 cannot be fully understood without taking into account the role that DESMI and the diocese of San Cristóbal, under the leadership of Bishop Samuel Ruiz, played in the making of the movement.

Today, DESMI works with more than 200 indigenous communities - most of them Zapatista autonomous communities - in the North, South, and the Los Altos regions of Chiapas. Its model of a "solidarity economy," which at the outset was mainly centered on creating community production cooperatives and promoting fairer exchange relationships between small farmers and consumers, has since been considerably expanded to incorporate food and seed sovereignty, agroecology, and gender equality, among other issues, as key elements of its proposal of indigenous development and autonomy. DESMI is in a unique position in the region in that it is one of the only 
organizations that works with both Zapatista and non-Zapatista communities. In the last few years, DESMI has established a solid bridge of communication between Zapatista and non-Zapatista communities, allowing the development of a shared regional political agenda on seed sovereignty. This dissertation analyzes the emergence and evolution of that local seed sovereignty project.

The protagonists of this ethnographic study are the peasants who participate in DESMI's "Guardians of Mother Earth and Seeds" project, a local initiative focused on seed and food sovereignty that began in 2015 . The project encompasses 25 non-Zapatista communities — 22 of them indigenous and three mestizo — in the Los Altos, Norte-Tulijá, and Los Llanos regions of Chiapas. In addition to those 25 communities, this study also incorporates data from 31 other indigenous communities (both Zapatista and nonZapatista) in the region, which are related to varying degrees with this initiative.

Although the ethnographic chapters of this research are mainly focused on the 25 non-Zapatista communities, this local project of seed and food sovereignty can only be fully understood by framing it in the broader context of the Zapatista movement and its decades-long struggle for indigenous autonomy in Chiapas. In this particular case, the conceptual frameworks, goals, and strategies of the Guardians of Mother Earth and Seeds project closely correspond to the EZLN's agenda of seed and food sovereignty, which since 2003 has constituted one of the key elements of the Zapatista model of autonomous government. This case study sheds light on why and how the Zapatista project of seed sovereignty has spread across the region and has now extended to non-Zapatista communities. It also compares the goals and impacts of this project of seed and food sovereignty between these two types of communities - Zapatista and non-Zapatista. This 
is one of the first studies to empirically examine the influence of the EZLN on the development of concrete political agendas in non-Zapatista communities.

Methodologically, this qualitative sociological study incorporates three main components: (1) participant and nonparticipant observation; (2) document analysis; and (3) semistructured interviews with community members, DESMI staff, members of the pastoral of the diocese of San Cristóbal, the staff of other local NGOs, and scholars from public universities and research centers. I conducted a total of 63 semistructured interviews. This includes 11 interviews with Zapatista community members, 28 interviews with members of non-Zapatista communities, 13 interviews with staff members of DESMI and other local organizations and activists, six interviews with active and former members of the pastoral of the diocese of San Cristóbal, and five interviews with scholars from public universities and research centers in San Cristóbal: El Colegio de la Frontera Sur (Ecosur), University of Chapingo, and the Center for Studies for Change in the Mexican Countryside (CECCAM). All of the interviews were conducted in Spanish and took place in Chiapas. In order to protect informants' identities, I have used pseudonyms for all respondents except the five scholars. A similar intention shaped my use of place names: I have identified the names of municipalities but not those of individual communities, with the purpose of protecting communities' confidentiality and preventing any possible risk. Following a similar logic, I have not identified any organizations or NGOs other than DESMI. The research methods are explained in far greater detail at the end of the dissertation. 


\section{My First Encounter with DESMI and the Selection of the Case Study}

I was 13 years old when the EZLN took up arms in January 1994. It was the first day of the New Year. Everyone was focused on NAFTA — our "formal" entry into the first world, according to Carlos Salinas de Gortari, the Mexican president at that time (Orgambides 1992, Salinas de Gortari 1992) — and the Zapatista uprising in Chiapas, Mexico's poorest state, was unexpected.

Before the extreme violence that would come with the War on Drugs has assaulted the country since 2006, Mexican people used to be relatively sympathetic to the "fair causes of the poor," mainly in the countryside where armed struggles for land had a long history. Indeed, the Mexican Revolution of 1910, which is considered to be the origin of the modern Mexican state, was essentially that: a peasant revolution that mobilized millions of people under the Zapatista slogan "the land belongs to those who work it." Perhaps it was the resemblance between the Zapatistas of 1910 and the Zapatistas of 1994 that explains why people were more excited than afraid — at least in my middle-class neighborhood in Mexico City—when the news of a peasant armed uprising arrived. Some of my neighbors were enthusiastically distributing printed copies of the First Declaration of the Lacandon Jungle, the EZLN's war declaration. I read it. I cannot remember what I felt or understood. What I remember is the enthusiasm of people around me, in the streets. My sensation was that something good was happening. Since that day I have attentively witnessed the development of the EZLN. This agrarian indigenous social movement became for me, and I think for many people from my generation, the social movement. 
My first encounter with DESMI was a stroke of luck. Paradoxically, it took place in Portland, Oregon, in October 2014. Elena, the current director of DESMI, was the main speaker at a conference at Portland State University about indigenous seed sovereignty in the global South. The event had been jointly organized by the San Francisco-based organization IDEX — now Thousand Currents—and the GMO-labeling “Oregon Right to Know" campaign. ${ }^{1}$ Elena's talk addressed how Mayan indigenous communities were resisting the introduction of GMOs in Mexico. She did not mention anything about the EZLN and only talked a little bit about DESMI. Essentially, she presented DESMI as one of the many small organizations located in San Cristóbal de las Casas that were working with indigenous communities. From that talk alone it would have been impossible to decipher the relationship that existed between DESMI and the EZLN. It was my intuition, probably, or my personal experience with the Zapatista movement—or both— that made me think that Elena could be an important contact for my future doctoral research in Chiapas. I approached Elena, who was willing to share her contact information with me, and at the end of our brief conversation she told me: "hopefully, we will meet again."

Almost one year later, I was in San Cristóbal de las Casas at the DESMI office for my first meeting with the entire six-member staff. Since DESMI is an organization that does not typically work with volunteers and researchers, they wanted to know what my research would be about, how it would contribute to the indigenous movement in Chiapas, and what my commitments to social justice issues were. I explained that I had followed the Zapatista movement since 1994, and then, during college, I had actively engaged with it and made several visits to some Zapatista communities. I also explained 
how the EZLN had deeply shaped my own perceptions about justice and social change, and how, in turn, those perceptions have influenced my scholarly trajectory. Apparently my answers satisfied their expectations, because I was allowed to join DESMI as a fulltime volunteer while carrying out my dissertation field research. I was assigned a desk and Elena asked me if I was ready to join the team, which in that case meant traveling to indigenous communities-DESMI staff members spend much more time in the communities than in the office. They did not explain anything else. But I already knew that this was normal in Zapatista territory: you learn from observing and do what others do.

Two days later I was traveling with Mariano-a staff member of DESMI— to the village of Cancuc to attend DESMI's first workshop on seed sovereignty. In the car, Mariano asked me what I knew about the 2007 Mexican Federal Law on Seeds. I answered that I did not know that such a law existed, and he gave me a book, Seeds of Hunger: Illegalize the Peasant Memory (CECCAM 2009; see Chapter 5) and told me to read the introduction and a couple of chapters before arriving in Cancuc. "Today's workshop will be about the law," he told me. "It is better that you have some information about it." That visit to Cancuc was my first time in an indigenous community since 2002, when I had last spent some weeks in Zapatista territory.

It took me a couple of weeks to identify that the central topic in all of these workshops was native seeds, and about a month to realize that I would not be visiting Zapatista communities soon — in fact, I noticed that I was excluded from all activities related to Zapatista communities. Once I understood that there was a project called "Guardians of Mother Earth and Seeds," and that I was the only person who was 
attending all of the workshops and meetings - each member of DESMI is responsible for a particular region and a specific number of communities-I became more proactive and began to contribute to the project with some ideas. Everyone was willing to listen to my suggestions and I was even allowed to make some presentations during the workshops. I gradually became responsible for registering the trajectory of the project: I took photographs, wrote reports after each workshop, interviewed people in order to evaluate the workshops' outcomes, and created some documents systematizing that information and making suggestions for the following workshops. I supported DESMI staff members with everything they needed in relation to this particular project. That is how the Guardians of Mother Earth and Seeds project became the central focus of my ethnographic research. Everyone in DESMI seemed satisfied with this arrangement, and they were willing to share with me all of the information and documents related to the project. This also implied that I began to have access to different spaces, actors, and documents - all related, although more indirectly, to the project. For instance, Elena allowed me to attend the meetings between DESMI and members of the diocese of San Cristóbal and shared with me all the documents from the diocesan Congress of Mother Earth. In the Research Methods, I explain in greater detail how I progressively gained access to Zapatista communities and to the other actors DESMI collaborates with. I also discuss further the limitations of this study and how my own positionality as both a critical academic researcher and an activist supporter of the Zapatista movement has shaped this research. 


\section{Research Questions and Preview of Key Findings}

Three central research questions guide this dissertation: (1) How do the increasing industrialization and commodification of seeds and agriculture affect peasant communities in Chiapas?; (2) How is the local seed and food sovereignty countermovement responding to those processes of commodification?; and (3) How does this case study contribute to understanding the relationship between capital's tendency to enclose the commons and the protective countermovements that attempt to resist such market encroachments?

While I address a broad range of issues in far greater depth in the body of the dissertation, I will summarize briefly here the major findings of this study. First, native seeds continue to be the foundation of subsistence agriculture in the study region, which means that these indigenous communities are largely still seed self-sufficient and therefore they do retain seed sovereignty. Second, the main impact of Green Revolution policies in these communities has been the chemicalization of peasant agriculture. Although these communities have never adopted industrial seeds - the core input of the Green Revolution technological package - they did adopt the agrochemicals that accompanied those seeds, and continue to use them. This chemicalization has entailed the partial commodification of subsistence agriculture, and has also generated negative impacts on the local environment and human health. Third, contrary to claims by key protagonists in the Mexican and international seed sovereignty movements, privatization, in the form of patents and seed certification laws, is not the primary risk posed by neoliberalism to native seeds in this region. Rather, it is the deterioration of subsistence agriculture, which is a direct outcome of the liberalization of national agricultural 
markets and the consequent dismantling of peasant agriculture, that constitutes the most direct threat to the reproduction of native seeds. Fourth, the local agenda of seed sovereignty has taken the form of a project of decommodification aiming to enhance subsistence agriculture. This project encompasses three elements: to strengthen and expand the commons, to reverse commodification, and to limit new market encroachments. Empirically, these elements are concretized in three overall objectives: to reduce communities' dependence on cash markets by reinforcing and expanding subsistence agriculture based on agroecological methods of production and food production collectives, to limit environmental degradation and agro-biodiversity loss, and to protect seeds and subsistence agriculture from further deterioration and also from potential external threats such as seed and land enclosure or genetic contamination.

This ethnographic case study contributes to scholarship on the political economy of seeds and, more broadly, the political economy of agri-food systems, by illustrating how indigenous communities contest both conceptually and in practice the dynamics of capital accumulation that threaten native seeds and peasant agriculture, as well as their own survival as people who live from the land. It contributes to the nascent literature on seed sovereignty with an ethnographic case study of local seed sovereignty in practice. This study also makes valuable contributions to scholarship on the Zapatista movement through a comparative case study that addresses the poorly understood political relationship between Zapatista and non-Zapatista communities and how regional political agendas emerge from the collaboration between them, as well as the EZLN's underresearched agroecology and food sovereignty agenda. 


\section{Structure of the Dissertation}

Chapter One establishes the theoretical framework for this research. First, I analyze the relationship between dynamics of expanded reproduction and what Harvey (2003) terms "accumulation by dispossession," and discuss how both have shaped the process of commodification of seeds. Then I approach the topics of decommodification and the commons, with a focus on seeds. Finally, I present and discuss the concepts of food sovereignty and seed sovereignty, analyzing them through the dynamic literature on the political economy of agri-food systems, and framing them in the context of the neoliberal agri-food system.

Chapter Two frames the discussion of these topics in the context of the Mexican state. I trace the trajectory of agriculture in Mexico from the end of the $19^{\text {th }}$ century to the present. I emphasize the role that the state has played in defining the rules under which capitalist markets and social movements can operate. As this chapter shows, the state is the central arena in which capital and social movements meet and social contracts are defined. As such, the state is a clear reflection of the evolution of class struggles. This chapter also establishes the background for understanding the relationship between industrial and peasant agriculture in Mexico since the Green Revolution.

The next four chapters focus on Chiapas and present and discuss the empirical data I gathered during my fieldwork. In Chapter Three, I introduce the region of my research and the communities that participated in this ethnographic study. I also frame this study in the context of the Zapatista movement. I discuss some of the key aspects of the EZLN's model of indigenous autonomy and how it has impacted the development of 
indigenous communities in the region. This analysis permits a better understanding of the objectives and strategies of the local food and seed sovereignty movement.

Chapter Four focuses on seeds and subsistence agriculture, and is divided in two major sections. First, I discuss the spiritual, material, and cultural meanings that native seeds hold for indigenous communities in Chiapas, which is important for understanding why the idea of protecting their native seeds is powerful enough to have brought together Zapatista and non-Zapatista communities in a common political effort against seed commodification. In this section I also describe the system of subsistence agriculture that predominates in these peasant communities. The second section focuses on the relationship between formal (industrial) and informal (peasant/native) seed systems, and how it is changing under neoliberalism. I also explore the impacts of the development of industrial agriculture and Green Revolution policies on subsistence agriculture and native seed systems in the region.

Chapter Five introduces DESMI and establishes the background of the Guardians of Mother Earth and Seeds project. In this chapter I discuss the antecedents of this initiative of seed and food sovereignty, and also describe the political context that made possible the implementation of this project in non-Zapatista communities. Chapter Six analyzes in detail the Guardians of Mother Earth and Seeds project and how the idea of seed and food sovereignty has been translated into a concrete initiative of decommodification focused on enhancing and expanding subsistence agriculture. I discuss how the concept of native seeds as a commons has evolved from a passive form ("these are our seeds and everyone has the right to access them," which coincides with the generalized notion of an open commons) to an active form ("we, peasant 
communities, reproduce our native seeds, which are essential for our social reproduction, and assume the responsibility to preserve them as non-commodified resources," corresponding to the notion of a protected commons). I conclude this chapter with an assessment of the concrete impacts, potentialities, and limitations of this project of seed and food sovereignty.

The Conclusion brings together the most important issues discussed throughout the dissertation, and summarizes the main findings and contributions of this research. Finally, I describe in detail my research methods and discuss the limits of this ethnographic study. I conclude this dissertation with a reflection on my own positionality as an independent researcher and also as an active supporter of the Zapatista movement. 


\section{CHAPTER ONE}

\section{CAPITAL ACCUMULATION, THE COMMONS, SEED AND FOOD SOVEREIGNTY, AND DECOMMODIFICATION}

I was born in Mexico City in October 1980. It was less than two years before Mexico defaulted on its foreign debt, signaling the beginning of the debt crisis that would submerge most of the global South in what has been called "the lost decade" (McMichael 2016b). I grew up in a period of financial crisis, currency devaluations, and structural reforms that would dismantle most of the welfare institutions and national economies of the post-revolutionary Mexican state.

The privatization of the state, however, has advanced at different speeds depending on the sector. This is why I was able to directly benefit from many public services and institutions that have remained outside of the scope of the neoliberal market, or at least did for some years. While a child, I had access to subsidized food through the free school lunches distributed in all public elementary schools across the country, as well as tortibonos (pre-paid native maize tortillas that government employees received as part of their salaries), and other staple food from Conasupo, a government agency created in 1962, which was the main market for small- and medium-scale farmers, and also the principal source of food for the most needy rural and urban dwellers. By the end of the 1990s, all of these programs had disappeared. However, the most significant impact of the state on my life has been to have access to free public education, from preschool through graduate studies. Even now, after almost four decades of neoliberal reforms, the 
Mexican government fully financed four years of my doctoral studies in the United States.

Having personally benefited from all those public institutions, it is clear to me how common resources and public welfare institutions contribute to the wellbeing of individuals and households. I also understand some of the ways in which the existence of commons promotes more egalitarian societies. Even though I was an urban middle-class girl, I was eating free school lunches, attending public schools, commuting by public transportation, and buying groceries at the Conasupo store in my neighborhood.

Even while the state played an active role in my life, I also simultaneously experienced the gradual but systematic privatization of the commons and the dismantling of most public welfare institutions. In the case of my family, we switched, almost imperceptibly, from public to private markets and services. We moved to an uppermiddle class neighborhood, my younger brother attended a private middle school, and now my niece and nephews attend a private elementary school where the first language is English.

The material consequences of such privatization, however, have been devastating for the poorest Mexicans, among them indigenous peasant communities. For small- and medium-scale farmers, the "lost decade" meant a double loss: they lost most of the services and subsidies that had been provided by the government (health, education, agricultural inputs, food, and other basic services) at the same time that they lost a subsidized national market—organized by Conasupo — for their crops. Gradually, those communities were excluded from the networks of the state. Subsistence agriculture, drug- 
crop production, or migration to the cities or the U.S. were the only alternatives that neoliberalism offered to them.

Among the many changes that I have witnessed in the last three decades, the one that strikes me the most is how widespread anti-commons and anti-state ideologies have become among Mexican people today. How did we go from believing that subsidized markets for agricultural products were an essential part of national development to thinking that private elementary education taught in English was a sign of progress for our country?

All these personal experiences have strongly influenced my interest in understanding the relationship between capital's tendency to privatize the commons and the emergence, in response, of social countermovements that attempt to resist that enclosure. This chapter approaches the analysis of these issues from a political economy perspective. The first section discusses some of the dynamics of capital expansion and accumulation, particularly the interconnection between a crisis of capital overaccumulation and what David Harvey (2003) terms "accumulation by dispossession." The second section explores the topic of the commons, in this case seeds, and examines the relationship between the dynamic of commodification and the opposite phenomenon of decommodification. The last section analyzes the neoliberalization of the agri-food system and discusses peasant food and seed sovereignty as a model for decommodification.

Throughout this chapter I explore multiple theoretical approaches on the topic of commodification of the commons, which several observers argue is a vital force driving capital expansion and accumulation. However, as many scholars, politicians, and activists 
have forcefully argued since Marx published Capital in 1867, the privatization of the commons and their organization by markets that are governed by the logic of price has detrimental effects for societies. It is worth questioning the desirability of allowing the price mechanism to govern complex natural resource systems and human relationships. Throughout the history of industrial capitalism, processes of capital expansion and dispossession have led to the emergence of social countermovements, which-to paraphrase Karl Polanyi — have attempted to protect society and nature from the destructive excesses of so-called "self-regulating" mechanisms of the market. Decommodification - the process of lessening the society's subjection to market discipline — is one core element that unites those countermovements and guides their efforts to create more egalitarian societies. The dynamic movements for food and seed sovereignty that have emerged all around the world in the last two decades exemplify this kind of decommodification countermovement.

\section{Primitive Accumulation and Imperialism}

\section{Primitive Accumulation: An Enduring Feature of Capitalism?}

Drawing on Adam Smith's concept of previous accumulation in The Wealth of Nations (1776), Karl Marx (1867) referred to primitive accumulation as the process through which the original mass of capital is created. The singular characteristic of this previous accumulation is it is "not the result of the capitalist mode of production, but its starting point" (Marx 2015: 507). The adjectives “primitive" or "previous" emphasize that this process happens before, and as a prerequisite to, the dynamic of reproduction of capital being put in motion. For both Smith and Marx, this original accumulation gives birth to the capitalist system and its two essential social classes: the owners of the means 
of production and capital, and a mass of workers who sell their labor power to the owners of capital in order to acquire their means of life.

Marx argued that the process of primitive accumulation was only made possible through dispossessing people from their means of subsistence, forcing them to sell their labor force in order to survive, and thus transforming them into wage workers: "The socalled primitive accumulation, therefore, is nothing else than the historical process of divorcing the producer from the means of production... The expropriation of the agricultural producer, of the peasant, from the soil, is the basis of the whole process" (Marx 2015: 508).

The word expropriation discloses the violent character of the process of primitive accumulation. However, as Marx noted when describing the enclosure of the commons in England, this process, with its multiple individual acts of forcible usurpation of common property, cannot be fully understood without recognizing the active role that legislation such as England's Poor Law or the Statute of Artificers played in systematically enforcing those dynamics of expropriation (2015: 511).

Thus, the concept of primitive accumulation encompasses three essential characteristics: (1) it is a process through which an original mass of capital is created; (2) this original mass of capital is created through the enclosure of the commons, or the "usurpation of common property," which implies that some people are dispossessed from the means of life essential for their own reproduction; and (3) the enclosure of the commons is enforced through legislation and the power of the state, and, therefore, individual acts of violence and usurpation are not enough to make this process to happen. 
Certainly, for both Smith (1776) and Marx (1867), the concept of previous or primitive accumulation refers to the "historical genesis" of capitalism (Marx 2015: 541). However, as Marx noted, this "historical genesis" differs from place to place and is never identically replicated: "the history of this expropriation, in different countries, assumes different aspects, and runs through its various phases in different orders of succession, and at different periods" (2015: 508). This passage is important for establishing an analytical distinction between primitive accumulation as a historical process through which capitalism is born, differing in time and sequence among countries and economic sectors, on the one hand; and primitive accumulation as the generic creation of an original mass of capital that is produced by "extra-capitalist" or "extra-economic" mechanisms, mainly through violent dispossession, expropriation, and legal enforcement, on the other hand. Marx referred to this second dimension of primitive accumulation when he argued that after the original mass of capital is created, its reproduction and expansion takes place under capitalist dynamics, such as those described in his law of value. In other words, the reproduction and expansion of that original capital becomes a fully capitalist process.

This second dimension is the essential dynamic described by the contemporary concepts of accumulation by dispossession (Harvey 2003) or accumulation through extra-economic mechanisms (Glassman 2006, Luxemburg 1913) that I discuss in the following section and refer throughout the dissertation.

\section{The New Imperialism and Accumulation by Dispossession}

In his book The New Imperialism (2003), the critical geographer David Harvey extends upon Rosa Luxemburg's thesis (1913), according to which processes of primitive 
accumulation and extra-economic mechanisms are essential for capital expansion and for the temporal resolution of crises of overaccumulation (i.e., surpluses of labor and capital that do not find opportunities for profitable invesment (Harvey 2004: 63). Through a detailed analysis of the neoliberal dynamics of capital accumulation and reproductionon which he further expands in his later works $(2004,2005,2011,2014)$-Harvey postulates that primitive accumulation is an ongoing process. "A general re-evaluation," Harvey writes, "of the continuous role and persistence of the predatory practices of 'primitive' or 'original' accumulation within the long historical geography of capital accumulation is, therefore, very much in order [...] since it seems peculiar to call an ongoing process 'primitive' or 'original' I shall, in what follows, substitute these terms by the concept of 'accumulation by dispossession"” (2004: 74).

Harvey argues that imperialism under neoliberal globalization is characterized by a rise in attempts to accumulate by dispossession - that is, "to release a set of assets (including labor power) at very low (and in some instances zero) cost" (2003: 149) —as the system deals with its inability to accumulate through expanded reproduction on a sustained basis (2004: 64). Harvey identifies privatization, both in the global North and South, as the "cutting edge" of accumulation by dispossession (2003: 148), and emphasizes the central role that the state continues to play in the implementation of such dynamics of accumulation: "as in the past, the power of the state is frequently used to force such processes through even against the popular will” (2004: 75). However, Harvey notes, the power of developed states in the global North, and the imperial and neocolonial international division of labor that they collectively enforce, is now articulated by international organizations such as the World Bank (WB), the International 
Monetary Fund (IMF), and the World Trade Organization (WTO), all of which are key actors coordinating the reproduction of the neoliberal system at a global scale.

Harvey asserts that all features described by Marx's concept of primitive accumulation "have remained powerfully present within capitalism's historical geography. Some of them have been fine-tuned to play an even stronger role now than in the past" (2004: 74). Among the wide range of dynamics of primitive accumulation described by Marx that continue to prevail under neoliberal globalization, Harvey highlights:

the commodification and privatization of land and the forceful expulsion of peasant populations; conversion of various forms of property rights—common, collective, state, etc.—into exclusive private property rights; suppression of rights to the commons; commodification of labor power and the suppression of alternative, indigenous, forms of production and consumption; colonial, neocolonial and imperial processes of appropriation of assets, including natural resources; monetization of exchange and taxation, particularly of land; slave trade; and usury, national debt, and the centrality of the credit system ruling capital reproduction (2004: 74).

Adding to those processes of dispossession that have been present throughout the history of capitalism, Harvey identifies several novel forms of "predatory practices of accumulation" (2004: 75). These include the imposition of intellectual property rights over genetic materials and other products; biopiracy and "the pillaging of the world's stockpile of genetic resources;" the wholesale commodification of nature in all its forms; the commodification of multiple cultural forms, histories and intellectual creativity; the 
privatization of public assets (e.g., education) and utilities (e.g., potable water, electricity, highways); and the reversion to the private domain of common property rights previously gained through class struggles.

Throughout his work, Harvey emphasizes that the crucial axis of capitalist expansion continues to be, as Luxemburg argued, the relationship between dynamics of expanded reproduction and dynamics of accumulation by dispossession, both of which are historically inseparable as mechanisms for resolving crises of overaccumulation. "Accumulation by dispossession," he writes, "can occur in a variety of ways and there is much that is both contingent and haphazard about its modus operandi. Yet it is omnipresent in no matter what historical period and picks up strongly when crises of overaccumulation occur in expanded reproduction, when there seems to be no other exit except devaluation" (2004: 76).

\section{Imperialism and Crises of Capital Overaccumulation}

Harvey conceives of imperialism as a form of the production of space (2004: 63). This conceptualization, he argues, helps to explain the tendency of capitalism to displace, both in space and time, its crises of overaccumulation. Harvey identifies two central ways in which the capitalist system deals with overaccumulation. It does this first through system-wide devaluations, and even the destruction, of capital and of labor power (e.g., through military or economic wars, or financial or debt crises); and second, through temporal and spatial displacements of capital that allow surpluses to be absorbed (2004: 63-64).

On the one hand, temporal displacements can occur through investments in longterm capital projects or social expenditures (e.g., research) that defer the re-entry of 
current excess capital into circulation well into the future (Harvey 2004: 64). On the other hand, spatial displacements are possible through opening up new markets, creating new productive capacities, resources, and social and labor possibilities: "the organization of wholly new territorial divisions of labor, the opening up of new and cheaper resource complexes, of new dynamic spaces of capital accumulation, and the penetration of preexisting social formations by capitalist social relations and institutional arrangements (such as rules of contract and private property arrangements) provide multiple ways to absorb existing capital and labour surpluses" (2004: 65-66).

\section{Seed Commodification and Accumulation by Dispossession}

The process of commodification of seeds reveals how the three essential characteristics defining Harvey's concept of accumulation by dispossession are powerfully present under neoliberal globalization. First, seed commodification is a process through which an original mass of capital is created-"the release of assets at very low (and in some instances zero) cost" (Harvey 2003: 149): in this case germplasm, which is patented. Second, the creation of this original mass of capital takes place through usurpation of common or public property: that is, the privatization of formerly public functions such as research on germplasm, the appropriation of seed-related collective knowledge, the privatization of germplasm, and the transfer of germplasm from the global South to the global North. Third, this appropriation is enforced both through the power of the state and via the institutional mechanisms of international organizations: imposition of Intellectual Property Rights (IPR) over germplasm, national seed certification and standardization laws, and the implementation of trade rules liberalizing agriculture markets (Kloppenburg 2004, 2010, 2014, Wattnem 2016). 
In subsequent chapters I will analyze in greater depth how both temporal and spatial mechanisms of the displacement of capital are present and inextricably intertwined in the evolving process of the commodification of seeds. In general terms, however, this takes the form of research on germplasm and biotechnology on the one hand, and the creation of new seeds, genetic engineering and seed-related technologies, and their corresponding markets, on the other. As Kloppenburg $(2004,2010,2014)$ and Wattnem (2016) document, the historical development of the seed industry also reflects the central role that privatization of public functions (research on germplasm) and the commons (genetic resources), plus international devaluations of capital that favor the collapse of national economies, play in the emergence and consolidation of new markets (hybrids, GMOs, agrochemicals) and of oligopolistic corporations (e.g., Bayer, DowDuPont, ChemChina).

\section{Commodification, Decommodification, and Seeds}

\section{Commodification and Non-Commodified Production}

According to Marx, a commodity is any object which satisfies human wants and is produced by human labor with a view to exchange (2015: 27). Commodification is the process through which formerly public, common-pool, or otherwise non-market goods, resources, and services are transformed into commodities and incorporated into the market (Jaffee and Newman 2013: 5). This process can occur through different mechanisms such as the privatization of natural resources or collective knowledge, cofinanced research and technological innovation between the public and private sectors, the private use of publicly funded research, and so on. As discussed in the previous 
section, these mechanisms of commodification embody the dynamics of accumulation by dispossession, devaluation, and the displacement of capital both temporally and spatially.

However, when analyzing the process of commodification, understanding how original capital is created through extra-economic mechanisms such as the privatization or enclosure of the commons is only half of the equation. It is also necessary to understand how that original mass of capital is incorporated into the dynamics of expanded reproduction - that is, the circular process of reinvesting part of the surplus value into the expansion of constant capital, which is explained by Marx in his General Law of Capital Accumulation — and how such economic relations "bring the independent producer [farmer] gradually but effectively into capitalist commodity production" (Kloppenburg 2004: 25).

This is a crucial point when studying seed commodification and its impacts on indigenous and peasant communities that are not fully incorporated into market relations, which is the predominant case in the region of Mexico, Chiapas, that is the focus of this study. The limited incorporation of such communities into the commodity market is reflected in three factors: (1) these communities still own some means of production such as land and native seeds, which are used to produce food and other goods and services for subsistence; (2) even if some peasants produce a surplus for the market, they also produce for subsistence; and (3) even if peasants participate in the labor market, as most in Chiapas do, their wages are only complementary for acquiring the means necessary for their communities' social reproduction. The money coming from production sales and wages is mainly used to complement self-produced food and to buy goods and services that are not produced within communities, including means of production (such as tools, 
machinery, or agricultural inputs). Money can also be saved for financing social projects or services that are not provided by the government (schools, churches, hospitals, or drinking water systems). An important variable of analysis in this study is the degree to which communities depend on the market - that is, labor, goods, and services marketsfor acquiring the necessary means for their own social reproduction. This factor will be useful for approaching the idea of communities' food security, which is the core of the more complex and political concepts of food sovereignty and seed sovereignty.

Kloppenburg (2004: 27) notes that independent agricultural producers progressively tend to reduce the scope of their productive activities once they are in contact with commodity markets. This happens, he argues, because producers gradually lose the ability to autonomously reproduce the means of production. This is particularly the case for communities that produce for the market:

because capitalist production represents a social concentration of both labor power and means of production, the products of capitalist enterprise tend to sell more cheaply than their equivalents produced under non-capitalist modes. The independent producer will be disposed to replace self-supplied means of production with purchased inputs as they lower the costs of producing a commodity for sale. This tendency gains strength to the extent that the petty commodity producer competes with other producers in a similar situation (Kloppenburg 2004: 26).

This process of commodification is reinforced by the structural tendency of the commodity system to create new social needs and markets of all kinds (Jaffee and Newman 2013). These can range from clothes, food, health, services, and recreation, to 
more sophisticated and efficient means of production (mechanized tools, industrial fertilizers, or hybridized seeds). Insofar as communities increase their dependency on these commodities, they are "bound ever more firmly and more completely to capital" (Kloppenburg 2004: 27).

Furthermore, this process of commodification and incorporation of rural communities into market relations can be accelerated through state mechanisms such as the distribution of subsidized industrial inputs (agrochemicals, industrial seeds, irrigation systems), or the opening of new subsidized markets for their products as a part of national development projects. This is notably the case in indigenous and peasant communities in Mexico, where Green Revolution policies_- national policies first implemented in the 1960s and 1970s, which promoted the industrialization of the agricultural sector through the introduction of industrial seeds, agrochemicals, irrigation, and other mechanized instruments - were the vehicle for their chemicalization. In Chiapas, for instance, more than 70 percent of the households cultivating native seeds currently use comercial fertilizers and herbicides; in the case of those cultivating commercial seeds, this figure increases to 95 percent (Perales 2016: 274).

Although I will develop this point further in Chapter 4, here it is pertinent to mention that seeds represent a particular case of the process of commodification within small peasant and indigenous communities in Mexico. Even though industrial seeds were an essential part of the Green Revolution package distributed by the federal government, many communities did not fully adopt them because native seeds continued to satisfy their pragmatic needs. For example, in the colder regions of Chiapas (e.g., Los Altos), native seeds tend to work better than hybrids, which is not always the case in warmer 
areas where hybrids and other commercial seeds are predominant: hybrids are recognized to be better for lodging ${ }^{1}$ resistance and for grain to be sold in the market, whereas native seeds resist storage pests better (Brush and Perales 2007, Perales 2016: 274). These pragmatic elements show some complexities of the process of seed commodification.

Seeds have two unique structural characteristics that impose important limits on their commodification: they are self-reproducing and they can be saved (Kloppenburg 2004, 2014). To this we need to add a third element: that industrial or improved seeds do not in all cases surpass the usefulness of native seeds, which is determined by the physical (altitude, land characteristics), technical (irrigation systems, machinery, agrochemicals), and market (production for sale, and market price) conditions of production in communities, plus cultural elements such as farmers' preference for some varieties over others (Perales 2016: 274, Perales et al. 2003a, 2003b, 2005).

Hence, when communities can reproduce their own means of production in an efficient way, they will tend to resist their commodification. This phenomenon is stronger when a means of production such as seeds is closely linked to the social reproduction of communities - in this case producing food for subsistence. In Chiapas, indigenous producers, particularly those located at higher altitudes (1400-2500 meters above sea level), are more subsistence-oriented and use more native varieties than mestizo producers do, who predominate in the lower altitudes (0-1400 meters), are more commercially oriented, and use more commercial varieties of maize (Brush and Perales 2007: 215).

In the case of indigenous communities, native seeds also frequently represent the core of their cultural reproduction (Brush and Perales 2007, Perales et al. 2005). This is 
particularly the case with domesticated crops in their centers of origin, such as maize in Mexico or potato in Peru. ${ }^{2}$ As I will further discuss in Chapter 4, for indigenous communities in Chiapas, native maize seeds are the material representation of their ancestors and spirits, and each planting cycle constitutes an important way in which they communicate with their ancestors. ${ }^{3}$ Community and family cultural and productive networks are further strengthened through the exchange and sharing of seeds among family members, an ancestral practice in indigenous communities. ${ }^{4}$ This pattern is stronger in higher-altitude regions, where two-thirds or more of households' seeds come from family members (Brush and Perales 2007: 218, 220). For these communities, reproducing and saving native seeds is a critical element of both their own food security and their cultural reproduction. These elements make seeds an "uncooperative commodity," a conceptual framework originally proposed by Bakker (2005) for analyzing the technical difficulties of commodifying water.

Here is where extra-economic mechanisms of accumulation come into play in the process of commodification. Kloppenburg argues that "for capital, the challenge has been to find ways to separate farmers from the autonomous reproduction of planting material and to bring them into the market for seed every growing season" (2014: 1227). He identifies two complementary ways in which this commodification has advanced: technological development through the hybridization and genetic engineering of seedsan economic mechanism of commodification—on the one hand; and legal regulation of seeds - an extra-economic mechanism—on the other. Kloppenburg argues that the technical path involves the plant breeding method of hybridization which renders the resulting crop economically (though not biologically) sterile...the 
profits produced by hybrids financed the growth of a robust private seed industry that then had both the resources and motivation to continue the commodification of the seed. Because many important crops cannot be easily hybridized (e.g., soybeans, wheat), a second path to corporate seed sovereignty was pursued: control via legislative fiat. And for capital the law has been a consistent and powerful mechanism for commodification of the seed...Over the course of nearly a century, legal arrangements have been used very effectively as a tool to achieve and maintain a quite considerable degree of corporate sovereignty over the seed (2014: 1227, 1232).

Tamara Wattnem further develops this proposition, arguing that "relatively new seed laws are becoming novel mechanisms of accumulation by dispossession in agriculture" (2016: 1). However, Wattnem makes a key distinction between intellectual property rights (IPR) and non-IPR-related seed laws. While the former address technological innovation and privatization of germplasm, the latter target informal seed systems - reproduction, saving, and exchange of seeds among peasant communities, and the work of independent breeders - by establishing certification requirements and quality standards for the marketing and/or exchange of seeds. Wattnem analyzes the case of Colombia — which passed a very stringent seed certification law in 2010 - and concludes that these laws might be "used to outlaw practices that are necessary for the functioning of informal seed systems. As a result, they are setting the stage for the further erosion of seed sovereignty" (2016: 1). I will expand the discussion of this argument in following chapters, but what is worth underlying here is the complexity of the dynamics of commodification and how they interact with non-commodified modes of production. 


\section{Decommodification}

In the previous section I discussed the relationship between processes of commodification and non-commodified production. Here I incorporate a third dimension into the analysis: decommodification. The study of seed commodification and peasant seed sovereignty requires taking into account the interactions between these three dynamics: commodification, the perseverance of non-commodified modes of production (subsistence agriculture, reproduction of native seeds), and decommodification.

According to John Vail (2010: 310), one of the main contemporary proponents of the concept, "decommodification is conceived as any political, social, or cultural process that reduces the scope and influence of the market in everyday life." Unlike the mere existence or survival of non-commodified modes of production, the concept of decommodification implies a proactive approach to "reduce our individual and collective dependency on the market (for livelihoods, social status, emotional sustenance)" (2010: 313), and to limit the influence of the market and its power over society.

Vail argues that the process of lessening our societal subjection to market discipline encompasses five elements: boundary protection, public goods provision, socially embedded circuits, social protection, and market transparency (2010: 313). The phenomenon of decommodification, writes Vail,

would incorporate processes that challenge and limit the scope of commodification by fencing-off non-market spheres from market encroachments. It would include initiatives that attempt to reverse the destructive aspects of the market by increasing the provision of public goods and by enhancing social protection. It would embrace measures that promote democratic control over the 
market by creating non-commodified economic circuits that are politically and socially embedded and grounded in a logic predicted on social needs rather than profit. It would include efforts to undermine the grip of market hegemony by increasing the transparency of the market and revealing its true social costs and consequences (2010: 312).

Therefore, decommodification practices are not only defensive-against the market— but they are also protective, and "could also generate wider social benefits by ensuring basic needs, enhancing individual capacities and capabilities, promoting social cooperation and collaboration, deepening social solidarity, and improving the social capacity for collective decision making" (2010: 313$)$.

The concept of decommodification, with its analytical, political, and normative complexity, is useful for analyzing the ideas of food sovereignty and seed sovereignty that are gaining attention worldwide. In the introduction I proposed to conceptualize the ideas of seed and food sovereignty as a model of decommodification. Interpreting food and seed sovereignty as decommodification offers a framework for exploring the limitations and potentialities of this concept and the goals of the social movements promoting it. I develop this discussion further below.

First, however, I want to discuss the relationship between commodification dynamics, non-commodified forms of production, and practices of decommodification for approaching the analysis of the commons - in this case germplasm, seeds, and the collective knowledge and cultural practices surrending them. 


\section{Decommodification and Common Pool Resources}

According to the American political scientist Elinor Ostrom, who in 1999 was awarded the Nobel Prize in Economic Science for her research on economic governance and the commons, ${ }^{5}$ two of the most polemic debates in political economy are (a) how natural resource systems might be governed, and (b) whether and how common-pool resources ${ }^{6}(\mathrm{CPR})$ can be managed in a way that prevents their degradation and destruction (1990).

\section{The Tragedy of the Commons and Privatization}

On the one hand are the proponents of either privatization or enforcement imposed by outside forces (the state, international authorities) as the best institutional means for solving the problem of overexploitation of CPR, and thus preventing the "tragedy of the commons." This expression was introduced in 1968 by the American ecologist and philosopher Garrett Hardin to symbolize the degradation of the environment caused by the common use of scarce resources. Hardin's central concern was the potential overconsumption and destruction of CPR resulting from the problem of overpopulation. He wrote that "the commons, if justifiable at all, is justifiable only under conditions of low-population density. As the human population has increased, the commons has had to be abandoned in one aspect after another... Individuals locked into the logic of the commons are free only to bring on universal ruin" (1968: 1248).

The rationale behind Hardin's "tragedy of the commons" is founded on an old idea dating back to Aristotle and Hobbes (Ostrom 1990: 2), which is that "it is impossible for rational creatures to cooperate" (Campell 1985: 3). In The Logic of Collective Action, Mancur Olson puts this idea in the following way: "rational, self-interested individuals 
will not act to achieve their common or group interests" if there is not an incentive for them to contribute voluntarily to the preservation of such common goods. Hence, wherever possible, individuals will try to receive the highest benefit while minimizing their sharing of the costs resulting from the collective use of CPR (Olson 1965: 2).

Ten years after the publication of "The Tragedy of the Commons," Hardin wrote: "if ruin is to be avoided in a crowed world, people must be responsive to a coercive force outside their individual psyches, a 'Leviathan,' to use Hobbes's term” (1978: 134). For Hardin, the only alternatives to the commons dilemma were "a private enterprise system" or "socialism" (1978: 124). Many scholars, economists, and politicians after Hardin have advocated privatization as the appropriate solution to managing the commons. Robert Smith, for example, suggested that "the only way to avoid the tragedy of the commons in natural resources and wildlife is to end the common-property system by creating a system of private property rights" (1981: 467).

The Indian activist Vandana Shiva strongly refutes those theses and argues that the tragedy of the commons is false. "Greed, domination, exclusion are not 'essential' human qualities," Shiva writes. "Functioning commons demonstrate that people can govern themselves, that democratic self-organization and self-governance work, and that people can cooperate, share, and jointly make democratic decisions for the common good" (2005: 54). Rather, it has been the privatization of the commons and the logic of overconsumption imposed by capitalist markets, Shiva states, that explains environmental devastation, poverty, and marginalization:

what has been called the tragedy of the commons is, in fact, the tragedy of privatization. The degradation Hardin projected on the commons results from the 
ability of the powerful to exploit resources beyond the ecological limits of renewability...Controlling the populations without controlling production and consumption patterns does not address the environmental crisis. The largest pressure on resources does not come from the large numbers of the poor, but from the wasteful production systems, long distance trade, and overconsumption in the First World (2005: 58).

This argument brings into the discussion two critical issues. The first is how the costs and benefits of privatizing the commons are distributed between those who appropriate them and those who are dispossessed and excluded from their use; and the second is how we evaluate the environmental and social devastation that has resulted from the private use of natural resources, which throws into question the real cability of markets to govern the commons.

Fictitious Commodities, The Double Movement, and Decommodification

The idea of enclosing or privatizing CPR, although currently in vogue under neoliberalism, has always been controversial. In 1944, the Hungarian economic historian Karl Polanyi had forcefully warned of the perils of allowing markets and the logic of price to regulate nature, one of what he termed the three "fictitious commodities." According to Polanyi, land (a generic term for nature), labor (human beings), and money ("a mere token of purchasing power") are not real commodities, because they are not objects produced for sale, even if markets exist for each one of them (1944: 75). Polanyi's central argument is that these three commodities cannot be subordinated to the demands of capital without disembedding markets from social relations - that is, eroding the dynamics of reciprocity, redistribution, and solidarity among people, and between 
humans beings and nature, all of which are essential for human reproduction (1944: 76, 79). The consequences of setting in motion such a process would be disastrous: "To allow the market mechanism to be the sole director of the fate of human beings and their natural environment, indeed, even of the amount and use of purchasing power, would result in the demolition of society" (1944: 76).

The enclosure and "ravaging of the commons" in nineteen-century England "and the social catastrophe which followed the Industrial Revolution" (1944: 79) are good examples of the devastating implications of imposing market rule over humans and nature: "the effects on the lives of the people were awful beyond description. Indeed, human society would have been annihilated but for protective counter-movements which blunted the action of this self-destructive mechanism...Society protected itself against the perils inherent in a self-regulating market” (1944: 79). Polanyi called this dialectical process the double movement. "The extension of the market organization in respect to genuine commodities was accompanied by its restriction in respect to fictitious ones," writes Polanyi. "While on the one hand markets spread all over the face of the world and the amount of goods involved grew to unbelievable dimensions, on the other hand a network of measures and policies was integrated into powerful institutions designed to check the action of the market relative to labor, land, and money" (1944: 79).

Throughout the history of industrial capitalism, processes of capital expansion and dispossession have induced the emergence of movements for protection or decommodification that attempt to counteract the power of markets over society and nature, and thus re-embed markets in society. These countermovements have been determinant forces explaining the development in the $19^{\text {th }}$ and $20^{\text {th }}$ centuries of welfare 
legislation and more egalitarian forms of social organization, such as public education and health, labor unions, or cooperatives. For Polanyi, state regulation of the markets for "fictitious commodities" was crucial to protect society from the destructive excesses (e.g., misery and environmental devastation) caused by the dynamics of an unregulated market economy.

Other authors have echoed Polanyi's argument. Gosta Esping-Andersen (1990), an important theorist of decommodification, emphasizes the progressive potential of welfare states for mitigating the perils of labor commodification. In the same analytical vein, Claus Offe (1996) has also noted the role of welfare state intervention in decommodifying crucial areas of social life. Regarding natural resources, Ehrenfield suggests that if "private interests cannot be expected to protect the public domain then external regulation by public agencies, governments, or international authorities is needed" (1972: 132).

The latter three scholars presume that central governments and international institutions can be adequate actors for managing most natural resource systems and ecological problems. The contemporary global multilateral framework governing crop genetic resources offers a good example of this logic. Crop genetic resources are regulated by the International Treaty on Plant Genetic Resources for Food and Agriculture (ITPGRFA, signed in 2003), which reaffirms states' sovereign rights over those resources, including the right to allow intellectual property over genetic material and whole plants. In this form, the ITPGRFA accepts the coexistence of both the rights of breeders and open access rights (Brush 2005: 22-23, 25). Thus, state sovereignty does not cancel, but regulates, the ability of private capital to exploit natural resource systems. 
However, as I will discuss later, different kinds of states in different historical moments regulate natural resources in divergent ways. In contrast to welfare states and their decommodification agendas, neoliberal states have tended to privatize many areas of social life, including natural resources. It is worth emphasizing here the important role of external regulation (states, international treaties, markets) as an institutional model to govern and manage CPR.

\section{Alternative Arrangements for Governing CPR}

A contrasting perspective to the binary between fully state or fully market solutions is offered by Ostrom. In her masterwork Governing the Commons (1990), Ostrom formulates a theory of self-organization and self-governance of small-scale, ${ }^{7}$ renewable, and scarce $\mathrm{CPR}^{8}$ (1990: 26). Based on a comprehensive analysis of empirical case studies of both successful and failed experiences, Ostrom concludes that these cases "shatter the convictions of many policy analysts that the only way to solve CPR problems is for external authorities to impose full private property rights or centralized regulation." Indeed, she writes, "most of the institutional arrangements used in the success stories were rich mixtures of public and private instrumentalities" (1990: 182).

Moreover, the concept of decommodification as defined by Vail (2010) suggests that the commons can be expanded far beyond simply fencing off already existing nonmarket spheres, to recovering commons that were previously expropriated by capital, and even to creating new commons and innovating mechanisms and institutional arrangements for governing them. Kloppenburg presents this idea when he introduces the concept of "repossession" as a counteracting force against the dynamics of accumulation by dispossession that are increasingly appropriating seeds and plant genetic resources. 
"The real challenge," he writes, "is not just to understand or to prevent appropriation of the commons, but to find the means to actually 'steal it back'...exploring what we might call 'repossession,' the actual recovery or reacquisition of what has been lost, and even the proactive creation of new, commons-like spaces in which more just and sustainable forms of social production might be established and elaborated" (2010: 368).

Using the example of open source computer software, Kloppenburg $(2010,2014)$ proposes the implementation of "biological open-source" arrangements - a way of mandating the freedom to use a resource and ensuring that it remains free (OSSI 2018) as a mechanism for creating "a protected commons populated by farmers and plant breeders whose materials would be freely available and widely exchanged, but would be protected from appropriation by those who would monopolize them" (Kloppenburg 2010: 367). This conceptualization of a protected commons regulated by a license, a form of contract, is the essence of the Open Source Seed Initiative (OSSI), of which Kloppenburg is a founder. This civil society initiative encompasses public plant breeders, farmers, small seed companies, non-profit organizations, and policy makers who are committed “to promoting and maintaining fair and open access to plant genetic resources worldwide" (OSSI 2018) According to OSSI, an open source seed "is seed of a plant variety the genetics of which cannot be restricted by patents or other intellectual property rights." "The OSSI Pledge reaffirms "four freedoms," which — as I will show in the next section - constitute the very foundations of the concept of seed sovereignty: (1) the freedom to save or grow seed for replanting or for any other purpose; (2) the freedom to share, trade, or sell seed to others; (3) the freedom to trial and study seed and to share or 
publish information about it; and (4) the freedom to select or adapt the seed, make crosses with it, or use it to breed new lines and varieties. ${ }^{10}$

These freedoms have historically been inherent to peasant and indigenous communities, particularly in the global South (see Chapter 4). However, this is not the case for developed countries in which seed systems are commodified almost in their totality and where most farmers, as in the emblematic case of the U.S., do not reproduce their own seeds anymore (Kloppenburg 2004, 2010, 2014), or if they do reproduce and save seeds they must pay for the use of eligible varieties, as in the case of the U.K. Farm Saved Seeds program under the Plant Varieties Act 1997 (BSPB 2013, U.K. Government 2018).

It is in this context of greater commodification of seeds where initiatives for "repossessing" common resources and creating new institutional arrangements—such as protected commons under open source licenses — make more sense. Kloppenburg (2014) notes that OSSI has not proved to be an appealing initiative for indigenous and peasant communities in the global South, whose native seed systems are still not significantly commodified but preserve their character as non-commodified areas of production and are conceptualized as open-access resources. In Mexico, for example, commercial seed sources account for only one-fourth of the maize seed planted, and this crop is mostly organized in informal seed systems and grown by smallholder farmers who obtain seed from their own harvest or from other farmers (Piñeyro-Nelson et al. 2009: 750-51). Kloppenburg (2014) also writes that for communities in the global South which have historically suffered the privatization and transfer of their genetic resources to the global North, an initiative coordinated by a legal instrument designed in the global North-in 
this case OSSI in the U.S. - can be perceived as a potential risk to their own seed sovereignty.

\section{Governing Common Resources at Global Scale: Limits and Possibilities}

All of these elements highlight the complexity of conceptualizing a protected common resource - in this case plant genetic resources, agricultural knowledge, and the cultural elements attached to seeds — as something that could be administered and governed at a global scale. This is also a good example of how the relationship between dynamics of commodification and the perseverance of non-commodified areas of production (subsistence agriculture and reproduction of native seeds) directly impacts a community's conceptualization of decommodification. In the global North, the advanced state of commodification of seed systems requires the implementation of "repossessing" strategies. In the global South, in contrast, the challenge is to preserve non-commodified areas of production that are directly linked to the social and cultural reproduction of communities. The critical element here is how peasant communities and public breeders can protect themselves from extra-economic mechanisms of commodification and enclosure that have proliferated around the world under the auspices of the World Trade Organization (WTO) and the Union for the Protection of New Varieties of Plants (UPOV) (Kloppenburg 2010, 2014, Wattnem 2016).

Mexico - a member of both the WTO and UPOV—clearly illustrates this global trend toward regulating seeds through legislation. As a requirement of the North American Free Trade Agreement (NAFTA), Mexico became a member of the UPOV and in 1996 passed a Federal Law on Plant Varieties, ${ }^{11}$ which lays down the foundations and procedures for the protection of plant breeders' rights. Then, in 2005, a Federal Law on 
Genetically Modified Organisms ${ }^{12}$ was approved with the objective of regulating their research, release, commercialization, exportation, and importation. Finally, in 2007 the government approved the Federal Law on Production, Certification, and Commercialization of Seeds. ${ }^{13}$ This law establishes the creation of the National Seed System (NSS), a consultative organism that provides policy guidance to the government on seed issues, and establishes the regulatory framework of the market for industrial seeds.

In this context of growing seed regulation and expansion of patented industrial seeds, will communities and public breeders be able to preserve those non-commodified areas of production without a legal instrument to fence them off? Will the definition of seeds as an open-access commons or "common heritage" be enough to prevent the further commodification of plant genetic resources, or will it be necessary to move towards a conceptualization of seeds as a protected CPR? As Kloppenburg notes, the long-term evolution of the private seed industry—-whose origin goes back to the 1890s in the U.S.proves that seed commodification has been a slow but constant process, and that both economic and extra-economic mechanisms have successfully reinforced it (2004).

\section{Food and Seed Sovereignty in a Neoliberal Context}

Since La Via Campesina (LVC) introduced the concept of food sovereignty in 1996, a whole range of social actors - social movements, urban and rural grassroots organizations, scholars, international organizations, and states, both in the global South and North—have discussed, reinterpreted, and added multiple dimensions to this definition (Desmarais 2015, Edelman et al. 2014, Martínez-Torres and Rosset 2010, Pimbert 2009, Pritchard et al. 2016, Schiavoni 2016, Wittman 2010). The rich discussion 
promoted by LVC has been further advanced in international fora ${ }^{14}$ where both members and non-members of the organization have come together to discuss the meaning of food sovereignty and how it can be attained. This has made this relatively new political concept, and the struggle to achieve it (Pimbert 2009: 7), a dynamic and transformative process (Edelman et al. 2014: 941, Pimbert 2009: 3), a “moving target, a reflection, in part, of the shifting terrain of global agrifood politics and the new actors who have taken it up" (Schiavoni 2016: 1).

The orientation of the food sovereignty movement is framed by the global agrifood system and the ways that neoliberal reforms have determined how, where, by whom, and what kind of food is produced and consumed (Bernstein 2016, Friedmann 2016, McMichael 2016a). The global food sovereignty movement conceptualizes itself as the peasant alternative to the neoliberal food and agriculture system (Desmarais 2015, Martínez-Torres and Rosset 2010, McMichael 2014, Pimbert 2009, Rosset and MartínezTorres 2012, LVC 2016, Wittman 2010).

\section{Food Regimes and Neoliberal Globalization: Corporate Power, Green}

\section{Neoliberalism, and Social Movements}

But what does the neoliberal agri-food system signify? A good starting point is offered by food regime analysis, a theoretical and historical method proposed by sociologists Harriet Friedmann and Philip McMichael in 1989 for explaining the role of agriculture and food in the capitalist system (see the dialogue among Berstein 2016, Friedmann 2016, and McMichael 2016). A food regime, according to its proponents, is characterized by particular political, economic, ecological, and institutional relationships attending the production, circulation, and consumption of food on a global scale. These 
relationships are geographically and historically specific, and they are linked to global capital accumulation trends more broadly. Regimes connote periods of relatively stable arrangements, which are punctuated by processes of rupture and change. Particularly important issues in food regime analysis are the role that hegemonic countries play in the configuration of international power relationships, how those relationships evolve (including the emergence of counteracting social movements), and how crises of overaccumulation are resolved (Bernstein 2016, Friedmann 2016, McMichael 2016a, Otero 2012b, Pechlaner and Otero 2010).

Friedmann and McMichael (1989) initially identified two historical food regimes. The first food regime (1870-1914), or "settler-colonial regime," was a period of British hegemony and the gold standard ruled international trade. This regime was characterized by the organization of a global market for cheap staple foods, mainly wheat and meat, produced by the settlers states of the U.S., Canada, Australia, and New Zealand. This production was focused on European markets and it marked the first time that a world price for those staple foods was established. According to Friedmann and McMichael, the cheap imports of food from the settler states were essential for financing the industrialization of Europe. This period also saw the rise of the nation state system and the "culmination" of European colonialism in Asia and Africa (colonies of occupation).

The second food regime (1945-1973), or "surplus regime," followed the collapse of Europe after World War II. During this period, the U.S. consolidated its hegemonic power and international trade was organized by the dollar system. This reorganization of international power relationships marked the end of European colonialism and the emergence of independent states from former colonies. The "surplus regime" reinforced 
the cheap food model through the industrialization of agriculture, the implementation of subsidies in the global North, and the transnational organization of agriculture sectors and agri-food complexes. The U.S. food surpluses - originally focused on Europe during its reconstruction —were from the 1960s allocated to the global South, either as food aid to the recently independent and food insecure countries (mainly in Africa and South Asia), or as subsidized imports for developing countries in the process of industrialization and urbanization (e.g., Latin American countries such as Mexico or Brazil). This period was characterized by the "decline of national agricultures" and the consolidation of a transnational model of food production and consumption (Friedmann and McMichael 1989). This "agriculture interdependency" reinforced food insecurity and dependence in the global South (Bernstein 2016, Friedmann 2005, 2015, 2016, Friedmann and McMichael 1989, McMichael 2013, 2016a).

There is not yet consensus about the existence or the nature of a possible third food regime (Bernstein 2016), mainly because the U.S. continues to be a hegemonic power, the dollar rules international monetary and financial markets, and the Bretton Woods institutional network born in the post-war period-including the World Bank, the International Monetary Found (IMF), the World Trade Organization (WTO), and the United Nations system - has considerably increased its role in the regulation of the international system (Bernstein 2016, Friedmann 2005, 2015, 2016, McMichael 2005, 2009, 2013, 2016a).

However, despite these continuities, McMichael has proposed a third food regime, the corporate food regime (1973-present), for characterizing the changes that the global agri-food system has undergone under neoliberal globalization (2005, 2009, 2013, 
2016a). A corporate food regime, as its name suggests, is one strongly controlled by corporations and global markets, which are coordinated through international organizations, mainly the WTO. In opposition to this corporate power, the peasant food sovereignty movement has emerged as a major counter-force challenging the foundations of the neoliberal food regime, "politicizing neoliberal 'food security' as an agribusiness project" (2016a: 648). Food sovereignty, McMichael argues, is a conceptual framework that "unmasks the undemocratic and impoverishing architecture of the 'free trade' regime privileging corporate rights over state and citizen rights" (2016a: 648). It is also a historically specific mobilization "informing an alternative world vision at a time when neoliberal capitalist institutions and policies are destabilizing whole societies and ecosystems" (2016a: 649).

Friedmann also recognizes important structural changes under neoliberalism, particularly the articulation at a global scale of agri-food business, markets, classes of consumers and diets, and social movements $(2005,2015,2016)$. However, she emphasizes that the institutional arrangement governing the agri-food system continues to be that of the "surplus" food regime. Hence, Friedmann proposes that instead of a definite third regime, we might be in a transitional period, which she calls the "corporateenvironmental" food regime (2005).

Friedmann also identifies environmentalism as a critical element of neoliberal globalization in two complementary dimensions $(2005,2015,2016)$. First, under neoliberalism, wholly new institutional structures have been created for regulating the environment at a global scale, from international climate change protocols and intellectual property rights frameworks, to financial markets for natural resources linked 
to conservationist projects. Michael Goldman (2005) calls this institutional arrangement green neoliberalism, which is primarily articulated at a global scale by the World Bank and the United Nations System (see Fletcher et al. 2018 for a more contemporary analysis). Second, the industrial agri-food system has proved to be the major economic sector contributing to climate change (FAO 2011, UN-Millenium 2005: 64, Weis 2013). This fact has positioned the agriculture and food industries - together with the fossil fuel complex — as the target of the international environmental and climate change social movements, the roots of which date to the 1960s (Friedmann 2016).

Although focusing on different issues and developing contrasting arguments, Friedmann and McMichael offer a broad picture of some of the central transformations that the agri-food system has experienced under neoliberal globalization. Other authors have elaborated complementary analyses that bring attention to particular dynamics shaping the neoliberal organization of agriculture and food economies (Appendini 2014, Araghi 2010, Fitting 2011, Lappé 2011, Lappé and Collins 2015, Moore 2012, 2015, 2010, Otero 2012b, Pechlaner and Otero 2010, Pritchard et al. 2016, van der Ploeg 2010, Weis 2013). In the following section, I summarize some of those arguments with the objective of tracing the structural contours of the neoliberal agri-food system from which the concepts of peasant food and seed sovereignty emerge.

\section{Neoliberalizing Agriculture and Food}

The contemporary agri-food system can be broadly characterized by the globalization of agriculture and food chains that has prevailed since the 1980s (Appendini 2014, Eakin et al. 2014a, Otero 2012b, Pechlaner and Otero 2010). The consolidation of agribusiness has been possible through the concentration and corporatization of whole 
food chains - from agricultural input suppliers of seed, fertilizers, machinery and equipment, to grain traders and the processing industries - and their integration into the global market economy (Appendini 2014: 3, Eakin et al. 2014a, 2014b). In Mexico, for example, an emblematic case has been the corporatization during the 1990s of the entire maize-tortilla chain — the main crop and food staple produced and consumed in the country—and then its articulation to the neoliberal food regime, or the "neoliberal maize regime," as Fitting (2011) has called it.

However, the neoliberal restructuring of food chains could not be possible without the active role of states (Appendini 2014, Bell and Lowe 2000, Eakin et al. 2014a, 2014b). Bell and Lowe distinguish between two complementary forms of state regulation of markets: negative regulation, which prevents interference (e.g., privatization of public institutions, elimination of subsidized markets), and positive regulation, which enables interference (e.g., public subsides to private corporations). These two forms, they argue, are inseparable: "a 'free' market — that is, a market in which the state does not intervene-is a theoretical impossibility in a state society" (2000: 285).

Corporatized food chains are then articulated to global industrial complexes and markets. According to Weis, the "industrial grain-oil-livestock complex" is the nucleus of the contemporary agri-food system $(2013: 4,93-128)$. It is sustained in the "cheap foodnature" (Moore 2012, 2010) and agrofuel/biofuel models (Baines 2015, Borras et al. 2010, McMichael 2012, 2010, Sassen 2014, White and Dasgupta 2010), increasingly dominant since the late 1960s with the Americanization and "meatification" of diets (Weis 2013: 4), and then with the emergence of agrofuel markets in the 1980s (Baines 2015: 2). The scale of this industrial complex ${ }^{15}$ is reflected in the fact that factory animal 
farms consume around one-third of all grains and almost half of the oilseeds produced at an international scale (Weis 2013: 4). Another important percentage of crops is destined to producing ethanol from corn and sugar cane, and biodiesel from canola oil and soybeans (Baines 2015, Bourne and Clark 2007). The U.S. is the top consumer and the second producer—behind China—of meat in the world (Weis 2013: 83, 85), and is also increasing its production of agrofuels (Baines 2015: 2).

Interwoven with the industrial grain-oil-livestock complex, biotechnology is "the chief technological form that continues and enhances the modern agricultural paradigm contained in the earlier Green Revolution" (Otero 2012b: 284). Behind these economies is the fact that the U.S. is "a driver in industrial agriculture's shift to GM varieties, both as the top adopter, globally, and in the development of technology" (Pechlaner and Otero 2010: 198). Of the top four U.S. agri-food exports—soybeans, maize, wheat, and cotton lint—all but wheat are primarily produced with GM seeds (Pechlaner and Otero 2010: 188, 190).

These GM crops and oils are "sold in volatile global markets as raw materials" (Otero: 282) and consumed as grains and oils-a considerable proportion under international aid programs destined to the global South (Lappé and Collins 2015)—and via animal products and processed foods, or indirectly for the production of agrofuels. Pechlaner and Otero write that the U.S. is clearly determined to "make biotechnology an American industry. This impetus features strongly in its neoregulatory agenda, which favors the private sector, specifically through the pursuit of strong intellectual property rights" (2010: 190). The U.S., they remark, "was instrumental in the establishment of global IPR protection through the Trade Related Aspects of Intellectual Property Rights 
Agreement of the WTO, and continues to protect the industry through lobbying against labeling GM products" (2010: 190). The acquisition of Monsanto by the German firm Bayer at the end of 2017 considerably changes this panorama of biotechnology as an "American industry" (Bray 2017). It is important to ask is whether Bayer will be able to overcome the strong opposition by civil society to GMOs that predominates in Europe.

This general characterization of the neoliberal food regime establishes the context in which the food sovereignty movement has emerged and evolved. It is useful for understanding both the structural dynamics and power relationships that the peasant movement attempts to counteract, and the challenges that it poses to the neoliberal agrifood system. However, what exactly does the food sovereignty movement propose as an alternative to the neoliberal food regime?

\section{The Peasant Alternative: Food Sovereignty}

A good starting point for approaching the food sovereignty movement is to make a distinction among its three essential dimensions: (1) food sovereignty as a global social movement challenging the conceptual foundations of the neoliberal agri-food system (Desmarais 2015, Edelman et al. 2014, Martínez-Torres and Rosset 2010, McMichael 2016a, 2014, van der Ploeg 2010, Wittman 2010); (2) food sovereignty as a statecentered policy framework defined around the concepts of food security, food as a universal human right, and farmers' rights (Henderson 2016, McKay et al. 2014, Pimbert 2009, Pritchard et al. 2016, Schiavoni 2016); and (3) food sovereignty as a praxis at the local and community level (Rosset 2012, van der Ploeg 2010). Each one of these three spheres has been discussed and well documented in the literature for the past decade. 
At the macro-level, the global food sovereignty movement has questioned the neoliberal paradigm of "free markets" and denounced its negative impacts on the lives of small peasants and agricultural workers. It has also called attention to the unequal and neocolonial relationships between the global North and South, and the unfairness of international trade and corporate rule. The food sovereignty movement has demanded structural changes in national policies, mainly the exemption of agriculture from trade agreements and the prioritization of food production for local markets instead of agroexports (Desmarais 2015, Martínez-Torres and Rosset 2010, McMichael 2016a, Wittman 2010)

At the meso-level, the food sovereignty movement targets the institutional arena of states and international organizations. One of its main achievements has been to advance a set of human and development rights in international fora and national agendas. The starting point was the introduction of the "Right to Food" in the FAOConvened World Food Summit (WFS) in 1996. According to De Schutter, the United Nations Special Rapporteur on the Right to Food, "the right to food is the right to have regular, permanent and unrestricted access, either directly or by means of financial purchases, to quantitatively and qualitatively adequate and sufficient food corresponding to the cultural traditions of the people to which the consumer belongs, and which ensure a physical and mental, individual and collective, fulfilling and dignified life free of fear" (FAO 2017). The WFS led to the Declaration of Rome, in which food security was defined as "the condition in which all people, at all times, have physical, social and economic access to sufficient safe and nutritious food that meets their dietary needs and food preferences for an active and healthy life" (FAO 1996). Although the Declaration 
focuses on the state as the preeminent actor and does not address the issue of farmers' rights, it was the first major accomplishment of LVC because it linked human rights to food security at the same time that it stressed the responsibility of the state to eradicate food insecurity (Pritchard et al. 2016: 698).

Closely related to the international agenda on food security, in 2004 the International Treaty on Plant Genetic Resources for Food and Agriculture (ITPGRFA) reintroduced two important concepts concerning the relationship between seeds and farmers. First, it defined germplasm as "common heritage," which means "the treatment of genetic resources as belonging to the public domain and not owned or otherwise monopolized by a single group or interest” (Brush 2005: 2). Second, it defined Farmers' Rights as "rights arising from the past, present and future contributions of farmers in conserving, improving, and making available plant genetic resources, particularly those in centers of origin/diversity. These rights are vested in the International Community, as trustee for preset and future generations of farmers, for the purpose of ensuring full benefits to farmers, and supporting the continuation of their contributions" (FAO 1998: 278).

Brush notes that this definition is problematic because, in contrast to breeders' rights, farmers' rights "were to be vested in the 'International Community' rather with individuals" (2005: 25). This implies, as Article 9 states, that the responsibility for their implementation rests with governments. It is important to note that the ITPGRFA establishes a multilateral system of access and benefit sharing concerning only 35 food crops and 29 forage plants. Thus, the rest of the genetic resources are formally excluded from the definitions of farmers' rights and "common heritage." In this way, the treaty 
makes a clear distinction between the two key economic sectors of biotechnology: pharmaceuticals and food and agriculture.

These two examples illustrate how the peasant movement has been successful in introducing some issues around food security and peasant rights into multilateral agendas. However, they also demonstrate the limitations of multilateral organizations and international treaties in influencing state policies. These rights remain an elusive goal because it is the responsibility of governments to define the legal, policy, and methodological frameworks for implementing them.

A final dimension of food sovereignty pertains to the local and community level. Although the goals of local food sovereignty agendas will be determined by local conditions and needs, it is possible to identify some particular elements that guide the praxis of small peasant communities, such as experimentation with organic production methods. Jan van der Ploeg (2010) proposes the idea of the "re-emergence of the peasantry" for approaching these elements from a theoretical perspective. ${ }^{16}$ His central thesis is that "farming is increasingly being restructured in a peasant-like way. This restructuring is an actively constructed response to the agrarian crisis that has grown out of five decades of state-induced modernization and is currently being accelerated by the financial crisis and generalized economic depression" (2010: 1).

The food sovereignty movement is in essence multidimensional and global, as is the agri-food system it attempts to counteract. But, what does food sovereignty look like when approached through empirical lenses? What are the specific dimensions of food sovereignty that communities can actually engage with? Why would communities embrace them and how might they organize their struggles around such specific 
dimensions? This study brings particular attention to one essential dimension of food sovereignty for peasant communities: seed sovereignty.

\section{Seed Sovereignty}

In the previous sections I argued that native seeds are at the core of indigenous communities' social and cultural reproduction in Chiapas (Brush and Perales 2007, Perales 2016, Perales et al. 2005). The centrality that native seeds have in the life of those communities confers on the idea of seed sovereignty a radical political importance. This is increasingly the case of the indigenous communities that the NGO DESMI works with in Chiapas, where seed sovereignty is becoming a latent arena of contention in a context marked by intellectual property rights over germplasm, national legislation regulating seeds, and the local expansion of GMO agribusiness (Bautista 2016, La Jornada del Campo 2015a, Morales 2016). The significance of the idea of seed sovereignty is magnified by the risks that communities in the study region perceive to their native seeds - even if those perceptions are not accurate in all cases — such as privatization, their genetic contamination through exposure to GM crops, ${ }^{17}$ and their degradation as a consequence of soil deterioration caused by the widespread use of agrochemicals. In this dissertation I contend that native seeds have acquired political relevance for these communities and that seed sovereignty is becoming a powerful framework for organizing their political struggles for food sovereignty and against neoliberal dispossession.

Before exploring how indigenous communities in Chiapas conceptualize their seed sovereignty, it is useful to look at the generic definition of the concept that has emerged from both the global food sovereignty movement, mainly LVC and Navdanya, 
as well as public seed breeders in the global North who are engaged in seed decommodification practices.

As I noted earlier, the roots of the seed sovereignty movement can be traced to the late 1970 s and are closely related to the evolution of the global anti-biotechnology movement (Schurman and Munro 2010). Schurman and Munro argue that the earliest activism around genetic engineering arose out of the encounter between "two very different sorts of concerns and two very different communities" (2010: 57). These included a group of critical scientists and environmentalists who were concerned about the dangers of this novel technology to human beings and the environment, and a growing community of development critics who denounced the impacts of industrial agriculture, particularly in the global South, and the increasing corporate power over seeds and its implications for the preservation of genetic diversity (2010: 57). Vandana Shiva was among the first voices denouncing the incidence of Green Revolution technologies and policies on environmental degradation, financial dependency, bankruptcy, and social fragmentation in farmer communities in the global South (Shiva 1991).

Although the political contention over seeds, biotechnology, and corporate agriculture has accompanied the development of the neoliberal agri-food system since the 1970s (Schurman and Munro 2010), Kloppenburg notes that the term "seed sovereignty" has only recently begun to appear in the discourse of social movements (2014: 1233). For instance, Vandana Shiva defines it in the Lexicon of Food as "the farmer's rights to breed and exchange diverse open source seeds which can be saved and which are not patented, genetically modified, owned or controlled by emerging seed giants" (2018). Even if 
Navdanya — founded by Shiva —is dedicated explicitly to achieving "seed freedom," this "ubiquitously deployed concept" has not been clearly defined (2014: 1234). In the case of LVC, the term seed sovereignty is "almost entirely absent [...] perhaps because even though seed is a central concern, LVC's conception of what constitutes food sovereignty also embraces land tenure, gender, water rights, demilitarization and migration" (2014: 1234). Despite the fact that both organizations have always included control over genetic resources as a key component of their agendas, neither of them have comprehensively defined what seed sovereignty means (2014: 1234).

In an attempt to reduce this conceptual lacuna, Kloppenburg advances a definition of seed sovereignty, which also informs the work of the Open Source Seed Initiative (OSSI). Drawing on materials from both Navdanya and LVC, Kloppenburg identifies the constitutive dimensions of seed sovereignty, its platforms of opposition, and its affirmative orientations:

- Principal and constitutive dimensions: the right to save and replant seed; the right to share seed; the right to use seed to breed new varieties; and the right to participate in shaping policies for seed.

- Key platforms for opposition: opposition to intellectual property rights; and opposition to genetically modified organisms.

- Affirmative orientations: community seed saving and exchange; agroecology and participatory breeding; legal sovereignty over seed; and openness to allies.

To what extent does this definition of seed sovereignty reflect the complex social process whereby indigenous communities in Chiapas organize their seed systems - that 
is, how they manage, preserve, and improve their seeds? In their study analyzing farmerled evolution practices in maize seed systems in Mexico, Dyer and Taylor write that "the analysis of seed dynamics requires understanding the purpose and object of farmer practices." For farmers, they emphasize, the "main goal is appropriating value, whether economic, cultural, or ritual. Whereas some might achieve this through improvement of local seed stocks, others might prefer to keep these stocks unchanged, defying our conceptions of improvement. Others may find it optimal to replace those stocks" (2008: 474). How communities conceptualize and appropriate such value is determined by the particular ecological, economic, cultural, and political contexts in which their seed systems evolve (Brush and Perales 2007, Dyer and Taylor 2008, Eakin et al. 2014a, Mercer and Perales 2010, Mercer et al. 2012, Perales 2016, Perales et al. 2003a, 2005). The concept of seed sovereignty, as defined above, will ultimately only have political value if it echoes the meanings that communities have assigned to their seed systems and the social processes sustaining them.

\section{Conclusion}

Throughout this chapter I have established a theoretical framework for approaching the political economy of seed commodification under neoliberalism. I went from defining what constitutes a commodity and explaining some basic dynamics of capital expansion and reproduction, including how crises of overaccumulation are resolved, to exploring the neoliberal organization of the global agri-food system and how some social movements have responded to it.

In this process I gave particular attention to the relationship among dynamics of commodification, non-commodified areas of life, and decommodification practices. The 
objective was to establish an analytical distinction between productive structures—both commodified and non-commodified — that sustain the social and cultural reproduction of communities, on the one hand; and political processes that seek to limit the expansion of capital over non-commodified spheres and, in some cases, even to reduce the scope of market influence over some other areas that it already controls, on the other.

Drawing on this distinction, I proposed to conceptualize decommodification dynamics as political processes. This emphasis on the political character of decommodification is useful for exploring empirically how indigenous communities in Chiapas conceptualize and govern the local commons, and how they organize themselves around collective practices. More specifically, this distinction allows for an analysis of the subtle but important differences between communities perceiving and reproducing seeds simply as open-access resources that are part of non-commodified circuits of their own social reproduction (subsistence agriculture), or as a protected commons, which entail the creation and implementation of specific organizational forms that enhance and fence them off from market mechanisms and commodification. 


\section{CHAPTER TWO}

\section{FROM THE PLANTATION ECONOMY}

\section{TO THE NEOLIBERAL "MODERNIZATION" OF MEXICAN AGRICULTURE}

This chapter traces the pattern of Mexican agriculture from the dictatorship of Porfirio Díaz (1876-1910) to the present. During this period, three predominant agrarian systems have shaped the Mexican countryside, and with it the lives of indigenous and peasant communities in Chiapas: the plantation economy (1876-1910); the postrevolutionary agrarian system (1914-1992); and the neoliberal agricultural model (1992 to the present).

Implemented by the Spanish colonizers in the $16^{\text {th }}$ century, the plantation economy reached its climax during the government of Porfirio Díaz. The increasingly high levels of land concentration in the hands of local and foreign elites, the harsh conditions of peasant labor in the plantations, and the systemic repression of social movements and political dissidents finally led to the Mexican Revolution (1910-1920). The ideals and objectives that gave life to the revolutionary uprising were captured in the Mexican Constitution of 1917. Among those objectives, agrarian reform, the development of peasant agriculture, and the nationalization of oil, land, and other strategic natural resources were emblematic of the social contract that shaped the postrevolutionary Mexican state (Gilly 1994, Leal 1974).

Regulated by Article 27 of the new Constitution, the post-revolutionary agrarian system was grounded in an extensive and gradual land reform that lasted for almost eight decades. A dual model of land tenure emerged from that process: on the one hand, private 
ownership of small and large parcels; on the other comunidades agrarias and ejidoscollective land holdings owned by indigenous and peasant communities—which could not be sold, transferred, or used as collateral for credit. As a direct outcome of the postrevolutionary land reforms, over 50 percent of Mexico's land surface (a total of 104 million hectares, or 257 million acres) was redistributed among peasant and indigenous communities (IICA 2012a: 20).

This long-term process of agrarian reform officially ended in 1992, when the Mexican government amended Article 27 as a prerequisite for its incorporation into NAFTA. This neoliberal modification not only ended land redistribution, but also established the legal foundations for the privatization of communal land. In this way, the government eliminated one of the central mechanisms that had maintained political stability since the revolution. This measure, together with NAFTA's agricultural chapter mandating the liberalization of agricultural trade, has generated growing social unrest across the Mexican countryside. The most organized manifestation of the social instability caused by the neoliberalization of Mexican agriculture was the uprising of the indigenous Zapatista movement (EZLN) on January $1^{\text {st }}, 1994$. The same day that NAFTA was enacted, an estimated 3,000 armed indigenous Zapatistas seized multiple towns and cities in Chiapas. During the following six months, the EZLN occupied over 50,000 hectares of land in the state, "forcing the government to recognize the continued need for land redistribution" (Harvey 1998: 2). It is estimated that the EZLN today controls about 60,000 hectares (148,000 acres) of occupied private finca land (van der Haar 2007: 491492). 
What is unique about the Zapatista movement is that it reveals the intricate ways in which indigenous communities relate to both the national and global commodity markets. Emerging in one of the poorest states in the country, the EZLN uprising unmasked the devastating consequences of an unregulated market economy. The indigenous Zapatistas not only disarticulated the neoliberal discourse of "modernization and development" that had accompanied the negotiations of NAFTA, but they also brought attention to the pervasive dynamics of capital accumulation and dispossession that for centuries have sustained the markets for colonial commodities. Since its armed uprising more than 20 years ago, the EZLN has consolidated itself as an active force contesting the logic of capital accumulation that has been imposed on indigenous communities since the colonial period. Throughout this process, the EZLN has built its own alternative model of indigenous development. Grounded in the principle of indigenous autonomy, this model encompasses, among other factors, control over its territories, food and seed sovereignty, collective systems of production, solidarity economies and fair-trade markets, gender equality, education, and public health (EZLN 2014a, 2014b, 2014c, 2014d, 2015).

However, the process of building autonomy has been slow and challenging. In the middle of a continuous low-intensity war-a government counterinsurgency that has combined military and paramilitary violence, a constant military presence in the area, and ongoing harassment of the civilian population (Klein 2015: 101) -Zapatista-aligned communities have struggled to overcome the pervasive conditions of extreme poverty that prevail in indigenous communities in Chiapas. In this adverse context, marked by 
autonomous control over territory as well as poverty and repression, food and seed sovereignty has become one of the key goals of the indigenous movement.

This chapter establishes the historical and contemporary background for understanding how these communities' struggles for land and food security have evolved into the concepts of indigenous autonomy and food and seed sovereignty. In the subsequent chapters, I will trace the origins and trajectory of the current agenda of indigenous food and seed sovereignty in Chiapas, and how it is connected to the broader model of indigenous autonomy that the Zapatista movement has adopted. As I will discuss in the following pages, the ideas of food and seed sovereignty and indigenous autonomy are closely interwoven with the contemporary development of the state of Chiapas. The roots of these concepts can be traced to the mid-1970s, when the plantation economy_on which most indigenous communities had been dependent for seasonal work - finally collapsed after an international commodity price crisis. This collapse led to the organization of a vibrant and heterogeneous indigenous movement, from which the EZLN eventually emerged.

\section{The Finca Economy: Accumulation by Dispossession,}

\section{Land Concentration, and Indigenous Labor}

The history of indigenous communities in Mexico is one of dispossession, domination, and exploitation by outsiders and local elites, but it is also one of indigenous rebellions against that oppression. Since the colonial period, the lives of indigenous peoples were defined by the development of the finca or plantation economy, the predominant agrarian system in the country until the Mexican Revolution (1910-1920) (Leal 1984: 13). Owned by local and foreign elites and with a majority indigenous labor 
force, the fincas were large plantations producing primarily for international markets. Most of the fincas were established on the very same lands that had been progressively expropriated from indigenous communities between the $16^{\text {th }}$ and the $20^{\text {th }}$ centuries. "During a period of four hundred years," wrote the historian Frank Tannenbaum in 1930, "the rural village population had gradually been forced to surrender their positions as free members of village communities and to an increasing extent have become peons who were tied to the plantations of foreign land owners, mainly Spaniards" (1930: 241).

This historical process of land dispossession and concentration in few hands reached its climax during the regime of Porfirio Díaz (known as the Porfiriato, lasting from 1876 to 1910). In 1878, only two years after assuming power, Díaz signed a federal law allowing the privatization of communal land (Favre and Frost 1973: 59).

Tannenbaum calculated that by the end of the Porfiriato over 95 percent of the communal villages in Mexico had lost their lands (1929: 151), and almost the totality of the rural population was linked to the fincas. " ${ }^{1}$ "At the outbreak of the revolution, in 1910, one half of the rural population lived on plantations, and was tied to the soil by a system of debts which made them slaves in fact, if not in law. The other half lived in nominally free villages, crowded into small areas on the mountainsides, or hemmed in by huge surrounding plantations. The large mass of the rural population was thus either directly resident upon, and kept tied to, the haciendas, or lived dependent upon, and subject to, the rule of the large plantation" (1929: 240).

In the state of Chiapas, almost 40 percent of the communally owned territory ( 3 million hectares) was privatized after the local government passed the Ejidos Law in 1892 (Baumann 1983: 13, Bellingeri and Gil 1980: 316, Reyes Ramos 1992: 36-37). In 
the particular case of Los Altos of Chiapas, the region with the largest indigenous population in the state, more than 50 percent of the communal land was privatized during those years (Benjamin 1990: 90). The concentration of land in the hands of a few families - which would be known as the Chiapanecan Family — was a direct outcome of this privatization: the number of latifundios (large landholdings of over 1,000 hectares) in the state grew from 3,159 in the 1890 s to 8,527 in $1910 ;{ }^{2}$ and by the end of the Porfiriato, almost 96 percent of agricultural land in Chiapas was owned by only four percent of the population (Favre and Frost 1973: 60).

Dispossessed from their lands, indigenous communities were forced to migrate to the nearby mountains for their own subsistence. However, their lives remained closely linked to those of the terratenientes (finca owners) (Baumann 1983, García de León 2002, Harvey 1998, Rus 1994). The poor quality of their new lands for agriculture and the harsh conditions in the mountains (e.g., lack of water), made these communities dependent on seasonal work in the fincas to complement their social reproduction (García de León 2002, Rus 1994). According to Reyes Ramos, at the end of the Porfiriato, almost 96 percent of the rural population in Chiapas - around 60 percent of whom were indigenous people (Baumann 1983: 10) —were peones, many of them landless or with insufficient land for their self-subsistence (Reyes Ramos 1992: 38).

Other studies give a more detailed picture of these trends. ${ }^{3}$ According to Katz, during the Porfiriato, temporary workers-as opposed to peones acasillados or permanent laborers who lived on the fincas, which had been the main form of labor since colonial times - became the main new source of labor in the fincas. This trend was an outcome of the high degree of land concentration and the expansion of a dispossessed 
labor force (Katz 1974: 41). It became cheaper for terratenientes to hire seasonal workers and pay them a salary — which was exchangeable in the tienda de raya or company store, a mechanism that induced workers' indebtedness and forced them to return for the next harvest in order to pay back their debts with labor - than to finance the social reproduction of peones acasillados (Katz 1974: 20). As Katz notes, the model of indebted seasonal workers implied a net transfer of the costs of social reproduction of labor from the fincas to households. It also reduced even further workers' access to land for subsistence agriculture, an access they had had either by using the land given to them as peones acasillados or by renting a plot of land in the fincas as tenants or sharecroppers.

The demand for seasonal labor grew at the end of the $19^{\text {th }}$ century with the dramatic expansion in the production of tropical commodities, such as rubber, coffee, tobacco, sisal, and sugar, for foreign markets (Rosenzweig 1960). With the exception of sugar, mainly produced in the center of the country, most of these commodities came from the states of Yucatán, Tabasco, Chiapas, and parts of Oaxaca and Veracruz (Katz 1974: 13-14). Propelled by a prosperous plantation economy, the competition for labor led to forms of debt peonage that were "more and more similar to overt slavery" (1974: 38). Only the availability of "subject, unpaid labor made such plantations feasible," writes Rus (2003: 267).

In his 1910 book Barbarous Mexico, John Kenneth Turner offered a vivid picture of the working conditions in the fincas across the South. One of the many descriptions comes from his visit to the tobacco plantations of Valle Nacional in the state of Oaxaca, in 1908: 
Valle Nacional is undoubtedly the worst slave hole in Mexico. In Yucatan the Maya slaves die off faster than they are born and two-thirds of the Yaqui [indigenous people from Northern Mexico] slaves are killed during the first year after their importation into the country. In Valle Nacional all of the slaves, all but a very few—perhaps five per cent—pass back to earth within a space of seven or eight months...And there are fifteen thousand of these Valle Nacional slavesfifteen thousand new ones every year!... The Valle Nacional slave holder has discovered that it is cheaper to buy a slave for $\$ 45$ [dollars] and work and starve him to death in seven months, and then spend $\$ 45$ for a fresh slave, than it is to give the first slave better food, work him less sorely and stretch out his life and his toiling hours over a longer period of time $(1910: 67,81)$.

Turner documented that, in addition to indigenous people, a large proportion of these slave workers were enganchados, poor people from the cities and other rural parts of the country who had been trafficked, or political prisoners sentenced to forced labor, as in the case of the indigenous Yaquis of Sonora sent to work in the fincas of Yucatan. Slavery, Turner emphasized, was an articulated system at a national scale that subsidized, largely but not exclusively, the tropical plantation economy in the Souther Mexico (1910: 110).

Throughout his book, Turner highlighted the active role of the federal, state, and local governments, public institutions (e.g., prisons), and legislation such as tax and vagrancy laws in articulating and defending this system of slavery (1910: 141). However, Turner noted, legislation and corrupt jefes politicos (municipal authorities) alone could not have succeeded without the militarization and para-militarization ${ }^{4}$ of the country and 
the systematic repression of labor struggles and social movements (1910: 141). During the government of Porfirio Díaz, labor movements and political dissidence were fiercely repressed. Some examples of the extent to which the Mexican economic system relied on such "extra-economic" means for propelling capital accumulation were the violent response to the strikes in Cananea, Sonora (1906), and Rio Blanco, Veracruz (1907) (de la Peña 1979: 224); the execution of more than 2,000 people after the Liberal rebellion of 1906 (Turner 1910: 151); or the enslavement of thousands of indigenous Yaquis who were sent to the plantations in the south in response to their rebellions against land dispossession (Sanderson 1981: 45-50).

The Mexican Revolution (1910-1920) was a countermovement in response to these conditions of extreme land concentration, exploitation of the labor force, and political repression. The post-revolutionary agrarian legislation contained in the Constitution of 1917, mainly in its Article 27, was a direct outcome of the struggles of peasant communities. Particularly relevant was the role of the original Zapatista movement that had developed in Central Mexico under the leadership of Emiliano Zapata. Encompassing more than 70,000 peasants in 1915 under the slogan "the land belongs to those who work it," the Zapatistas were one of the most important insurgent groups of the revolution (Sanderson 1984: 27). The antecedents to Article 27, which governed land reform until 1992, can be found in the Zapatista Agrarian Law of 1915, first implemented in the territories controlled by the Zapatistas, particularly in the state of Morelos, and then translated into a national platform. It essentially called for restoration of community lands that had been expropriated during the Porfiriato (Barry 1995: 19). It 
is after these Zapatistas of the Mexican Revolution that the contemporary indigenous movement in Chiapas adopted its name: the Zapatista Army of National Liberation.

\section{The Post-revolutionary Agriculture System:}

\section{Agrarian Reform and Campesino Agriculture}

The agrarian system that emerged from the Revolution was a complex mosaic reflecting the diverse and contrasting interests and objectives of the actors that had participated in the armed uprising. Essentially two broad groups, and two corresponding models of agrarian development, shaped the landscape of the post-revolutionary Mexican countryside (Barry 1995: 27, Hewitt de Alcantara 1976, Sanderson 1984: 36).

On one hand was the group of medium-scale landowners from the north of the country who, under the leadership of Francisco I. Madero, initiated the armed uprising in 1910 that would overthrow the dictator Porfirio Díaz. Known as the Caudillos of the Revolution — who governed the country from 1910 until 1934 - these ranchers demanded access to political power and the redistribution of land and resources concentrated in unproductive latifundia, many of them owned by a foreign elite and the Catholic Church. The main concerns of this group were the modernization of capitalist agriculture and the dismantling of old oligarchies that had monopolized most of the productive resources in the country, as well as control of the state (Gilly 2001, 2015, Leal 1974). According to Tom Barry, for the caudillos of the north, agrarian reform was seen as a mechanism for consolidating a dynamic commercial farm sector, consisting largely of irrigated smalland medium-sized landholdings and large agribusiness. In this post-revolutionary model of economic development, agrarian communities and ejidos were assigned the complementary role of providing a source of labor for that envisioned modern 
agricultural sector. With this objective in mind, marginal rainfed lands destined for subsistence agriculture would be redistributed among peasant and indigenous communities (Barry 1995: 18-21).

However, although the armed uprising had been initiated by a group of mediumscale landowners from the north, it was the mass armies of peasants and rural workers who finally defeated the counter-revolutionary movement that had spread from 1910 to 1914 (Gilly 1994: 171). Under the leadership of Emiliano Zapata, a peasant himself from Morelos in central Mexico, and Francisco Villa, of peon origin from Chihuahua in the north, these groups constituted the second axis of the revolution (Gilly 1994). Their demands, coming from the grassroots of the Mexican countryside, greatly shaped the social contract that was encoded in the new Constitution of 1917 (Córdova 1977: 97). Particularly, the agrarian agenda of the Zapatista movement, first implemented in the state of Morelos and then translated into a national platform, was the key factor defining the post-revolutionary model of campesino agriculture (Barry 1995: 18, Sanderson 1984: $36)$.

There were four core demands of the Zapatista Agrarian Law of 1915: the restitution of the communal lands that had been expropriated during the Porfiriato; the recognition of communal rights to land; the right of small farmers to control their own villages; and the establishment of federal agencies for irrigation, rural credit, agricultural education, and research supporting peasant agriculture (Sanderson 1984: 27). Together, these demands constituted a radical program that stressed the importance of extensive land reform, communities' self-government, and state support to campesino agriculture (Barry 1995: 18). 
What resulted from the combination of these two agrarian programs, one coming from medium-scale landowners in the north, and the other from peasant communities in central Mexico, was a hybrid or bimodal model encompassing both commercial and campesino agriculture (Barry 1995: 27). This dual model became the foundation of Mexican agriculture from the revolution until 1992, when the Mexican government amended Article 27, ending land redistribution and allowing the privatization of communal land.

During the nearly eight decades of post-revolutionary agricultural policies, the balance between commercial and peasant agriculture was defined by the evolution of alliances and class struggles among the economic elites, the government, and peasant movements. The development of these power relationships explains the uneven implementation of agrarian reform, both in geographic area and speed, across the national territory. For instance, in the regions controlled by the Zapatistas, land redistribution and state support to peasant agriculture (e.g., rural credit, irrigation infrastructure, subsides) were implemented beginning in the last years of the revolution. Sanderson calculates that an average of 63.7 percent of peasant communities in Central Mexico were considered by the federal government as eligible to receive land during the years following the revolution. The state of Morelos, where the Zapatista movement had originated, registered the highest percentage (78.6\%) in the country. These numbers contrasted with the Southern states, where the plantation economy was stronger and the peasant movement weaker. For instance, by 1934, only 14.9 percent of peasant communities in Chiapas were considered eligible for land, 17.5 percent in Campeche, 7.2 percent in Quintana Roo, 16.1 percent in Tabasco, and 24.1 in Yucatan (Sanderson 1984: 45). 
In the north of the country, the government supported the expansion of a mediumscale commercial agriculture, now controlled by the caudillos of the revolution, and land redistribution among peasant communities was limited until the government of Lázaro Cárdenas (1934-1940). The proportion of communities eligible for land in the region of the caudillos was 26.5 percent, and only 20.5 percent for the Pacific North (Sanderson 1984: 45). However, the modernization of the agricultural sector, together with the progressive industrialization of the region that had begun during the Porfiriato (Katz 1974: 3), favored the development of a more regulated labor market, which had been one of the central demands of the Villista movement.

In contrast to the substantial agrarian changes in central Mexico and the north, southern Mexico, which had remained marginal to the armed confrontation, did not experience radical changes. Indeed, the plantation economy there kept growing even after the revolution. The production of coffee in Chiapas reflects this trend: from 2,900 tons produced in 1900, the numbers grew to 5,500 tons in 1910, and 13,700 tons in 1929 (Baumann 1983: 26).

The lack of strong regional revolutionary groups contesting the power of local terratenientes and proposing an alternative model of agriculture favored the perpetuation of the status quo imposed by the finca economy. This was particularly the case in Chiapas, where the local oligarchy successfully resisted the implementation of most revolutionary laws that other states were already enforcing. It was not until the government of Cárdenas (1934-1940) that the terratenientes were forced to introduce some changes, and even then, many reforms were only partially implemented and were 
adjusted to the dynamics of the finca economy (Baumann 1983, García de León 2002, Reyes Ramos 1992, Rus 1994).

\section{Lázaro Cárdenas: the Revolution of the Indios in Chiapas}

A good example of the complex process of confrontation and negotiation between local elites and the federal government was the development of the Departamento de Protección Indigena (Department for the Protection of Indigenous People), which is analyzed in detail by Jan Rus (1994). Created in 1936, the department was focused on the central region of Los Altos of Chiapas, where the Tseltal and Tsotsil indigenous peoples were concentrated. Together, these two indigenous groups constituted one-third of Chiapas's population and the large majority of migrant labor that made possible the state's export agriculture, located in the regions north and south (Rus 1994: 276).

Under Erasto Urbina (the first federal official who spoke both the Tseltal and Tsotsil languages), the department immediately started to reorganize the political structures of indigenous communities in the region. Urbina's first measure was to replace all the authorities of native municipalities with people close to him. Attached to the federal government, this new indigenous elite came to concentrate most of the political and economic power inside of communities until the mid-1970s, when new indigenous movements, including the EZLN, contested those co-opted power structures (Rus 1994: 277, 2012-113). Supported by this new political network, Urbina organized the occupation and expropriation of fincas in Los Altos - which were not the coffee fincas that sustained export agriculture. Although it was not the department's responsibility to expropriate those lands, Urbina and his group of indigenous officers simply invaded and 
seized the properties, and they left the responsibility for completing the expropriation and indemnifying the former owners to other government agencies (1994: 279).

Simultaneous to these land occupations, in 1937 Urbina organized the Sindicato de Trabajadores Indigenas (STI, Indigenous Workers Labor Union). This labor union enrolled all seasonal coffee workers from Los Altos who traveled annually to the fincas in the north and south of the state. By the end of 1937, the STI had enrolled almost 25,000 indigenous workers (Rus 1994: 279). Among other measures, the government enacted a series of regulations establishing that it was illegal to hire coffee pickers who were not registered in the STI, that wages had to be paid in cash, that the tiendas de raya and old workers' debts had to be eliminated, and that fincas needed to keep a clear documentation of new wage advances (1994: 279).

According to Rus, although these measures were first resisted by the terratenientes, "this mediation was eventually accepted, and the government settled down to the task of assuring the coffee zone a steady flow of workers" (1994: 279). Recruiting and disciplining workers became the responsibility of the STI's officers. "Acting through their municipal ayuntamientos," writes Rus, "they [STI's officers] now used the native police to round up more workers when they were needed to fill monthly hiring quotas, and applied traditional sanctions - including time in community jails - to those who left their fincas before fulfilling their contracts. Meanwhile, the STI never called a single strike, nor do any of the surviving Indian officers recall ever having participated in the bargaining sessions between finqueros and state government officials" (Rus 1994: 280). The result, Rus continues, was a new labor system in which the government placed itself between the coffee planters and the indigenous workers: "In return for a substantial 
improvement in working conditions, then, the state - that is Urbina - not only penetrated the Indians' internal community governments, but enlisted them in the task of subordinating the state's landowners and planters to the national government and party (1994: 280).

Another important transformation that occurred during the years of Cárdenas, greatly influenced by Urbina's interventions, was the spread of indigenous rebellions on the fincas in central Chiapas. A good illustration of the intricate ways in which Urbina's policies disrupted the power relationships in the region between terratenientes and indigenous workers is offered by the Mexican writer Rosario Castellanos in her semiautobiographical novel Balún Canán (1957). Castellanos describes the life on her family finca during those years - the Castellanos were one of the most important terraniente families in Chiapas. She recounts one incident that happened during the harvest of 1938. Urbina had passed a new regulation requiring that fincas must have an elementary school and a teacher for their workers' children. Castellanos' father, as many other terratenientes in the region, decided simply to ignore this regulation. However, when workers began to demand that a school be constructed and a teacher assigned to it, her father responded with selective repression and some workers were assassinated. Only after an official of Urbina's government visited the finca was the school built-a room with dirty floor - and the terrateniente's nephew designated as the teacher. The school was a symbolic victory. The children, besides being malnourished, did not speak Spanish, and the teacher did not speak Tseltal, the indigenous language. However, when workers discovered that the "teacher" was alcoholic and had hit some kids, they set fire to her father's maize plots in the middle of the night. The fire lasted for days and consumed 
most of that year's harvest. Many workers refused to help extinguish the fire and no one denounced those who had initiated it; "it just happened, patrón," everyone murmured.

The confrontation between workers and the patrón reached such intensity that the Castellanos family had to move to the city of Comitán. Only Castellanos' father and some other mestizo people remained on the finca with the indigenous workers. One year later, the whole family moved to Mexico City, where Castellanos' father fruitlessly spent months attempting to persuade an authority in the Department of Agrarian Reform to return the lands that indigenous communities had invaded on his finca. The family never regained its previous power. They remained afraid of the indiada-a pejorative word referring to the sporadic rebellions of indigenous people against mestizo power. Nor did indigenous workers forget the impact of their silent resistance. Cárdenas was their ally. Even today, the years of Cárdenas are referred as la revolución de los indios (the revolution of indigenous people) among indigenous communities in Chiapas (Rus 1994: 1).

This kind of sporadic confrontation between terraterientes and indigenous workers escalated in intensity in the following years (de Vos 2002: 194-204). Indeed, the dynamic of land occupation by indigenous communities became one of the central mechanisms of land redistribution in the state: communities would invade lands both from the fincas and federal territories and then demand that the government recognize their expropriation as ejidal lands (de Vos 2002: 224-231). 


\section{Chiapas During and After Cárdenas: Commercial Agriculture, Indigenous}

\section{Labor, and Corporatist Control}

The historian Adolfo Gilly refers to the years between 1914 and 1934 as "the interrupted revolution" (la revolución interrumpida) (Gilly 1994, 2015). This definition stresses the revolutionary character of the government of Lázaro Cárdenas that followed (1934-1940), particularly his commitment to large-scale agrarian reform and peasant agriculture, which had been the central demand of the Zapatista peasant movement (Gilly 2015: 75-77). Cárdenas was the president who expropriated and redistributed the largest amount of high quality land and water resources by far to peasant communities. As part of his agrarian reform agenda, in 1936 Cárdenas created the National Ejidal Credit Bank (Banco Nacional de Credito Ejidal), and in 1938 the National Peasant Federation (CNC, Confederación Nacional de Campesinos), a corporatist mass organization encompassing all the beneficiaries of agrarian reform (Gilly 2001: 148-157). The agrarian and social reforms under Cárdenas were profound. By the end of his government in 1940, Cárdenas had distributed more than 20 million hectares - the climax of land distribution in the history of the country. Ejidos accounted for one-half of Mexico's cultivated area, about one-third of ejidatarios were entitled to receive credit, and landless laborers had declined from 68 percent to 36 percent of the rural workforce (Barry 1995: 23, Sanderson 1984: 128).

These reforms laid the groundwork for the commercial agriculture boom that followed the Second World War. In Chiapas, as in the rest of Mexico, state support for agro-export production significantly increased and diversified in an attempt to harness the benefits of the rapid growth of global markets and the sharp rise in commodity prices. 
This boom in commercial agriculture lasted for the next two and a half decades (Barry 1995: 28-29, Hewitt de Alcantara 1976). During these years, Chiapas experienced a rapid expansion of its agricultural frontier toward less-populated tropical forest areas (de Vos 1988, 2002). The state became Mexico's largest producer of coffee, the leading source of maize and beans for the national market, and one of the top three suppliers of sugar, rice, cacao, tropical fruits, and cotton (Rus 1994: 289). The government fostered this economic boom by expanding Chiapas's infrastructure (dams, roads, railways, and ports), issuing "certificates of inaffectability," whose objective was to reassure the owners of new agribusinesses that they would not be affected by agrarian reform, and providing them with technological inputs, credit, crop insurance, and guaranteed prices (Rus 1994: 290). As in the Cárdenas years, the federal government continued to play a key role in redirecting Tseltal and Tsotsil indigenous labor toward these new economies controlled by small- and medium-scale ladino farms (Rus 1994: 290-291).

The main difference between Cárdenas and the governments that succeeded him was the scale of both land redistribution and the government's commitment to peasant agriculture. Never again did peasant communities benefit from the volume and quality of lands that were expropriated and collectivized under the Cardenista agrarian reform (Barry 1995: 25-29, Sanderson 1984: 72, 90-98). Neither were terratenientes ever again seriously threatened with mass expropriations. Indeed, most of the lands redistributed to peasant communities between 1940 and 1970 were rainfed federal lands that were not suitable for agriculture, such as those on the margins of the Lacandón jungle, which began to be colonized by landless peasants in the 1950s. Only during the government of Luis Echeverría (1970-1976) did communities briefly benefit again from the distribution 
of average-quality land (de Vos 2002: 224-230, Harvey 1998: 61, 76, Sanderson 1984: 72).

Accompanying the redistribution of federal lands, repression against indigenous groups occupying fincas increased in this period, and the government silently allowed the terratenientes' guardias blancas (paramilitary groups) to regain some of their previous functions, mainly repressing indigenous workers (de Vos 2002: 197-204, Rus 1994: 285). The elite of indigenous leaders, who had been formed and co-opted by the federal government during the years of Cárdenas, also played an important role in regulating discontent inside communities. Over the years, those indigenous elites became powerful actors who controlled the distribution of government aid and economic resources to communities, and regulated the relationship between landowners and indigenous workers.

Therefore, over these three decades (1940-1970), the dispute over land between fincas and indigenous communities in the state was contained through the distribution of federal lands, ${ }^{5}$ the rapid expansion of a labor market in which wages complemented communities' subsistence agriculture, the repression of sporadic indigenous revolts, and the political and economic control of communities by an indigenous elite closely linked to the federal government, landowners, and ladino merchants (Rus 1994, 2012).

However, this model had its limits. Rapid population growth, the lack of sufficient arable land, and limited state support to peasant agriculture kept land conflicts latent (Barry 1995: 28, de Vos 2002: 245, Sanderson 1984: 99). It was in the mid-1970s, after the global commodity price crisis hit Chiapas and the labor markets related to those communities started to collapse, that some oppositional groups began to emerge inside 
indigenous communities and challenge the corporatist government structures controlled by a too-powerful and wealthy indigenous elite (Rus 2012: 21). This was the time when indigenous autonomy first became a political mobilizing framework among young landless peasants in the state, many of whom would eventually swell the ranks of the new Zapatista movement (Barry 1995: 28, de Vos 2002: 323).

\section{The Neoliberalization of Mexican Agriculture}

\section{The Limits of Peasant Agriculture}

The bimodal Mexican agricultural system that had emerged from the revolution showed its first signs of crisis by the late 1960s. Together with agribusiness and mediumand small-scale peasant agriculture, an increasing underclass of landless and subsistence farmers - those who owned less than five hectares of land and depended on wage labor to maintain their families—-had regained a central role in rural Mexico (Barry 1995: 28). According to the 1981 agricultural census, only 16 percent of the ejido land was irrigated, and almost 64 percent of ejidatarios had farms of less than five hectares, which are generally insufficient to maintain a family (De Janvry 1995: 1350). Several factors led to this outcome. The first was the growth of the rural population, which created a situation where most of the lands that had been distributed in previous decades were now subdivided among expanding families. Sanderson calculates that between 1930 and 1970, the number of land reform beneficiaries had increased from over 600,000 to almost 2.1 million people. In 1970, approximately 2.2 million ejidatarios were holding almost 80 million hectares of land. However, despite this absolute increase, by 1970 only 27 percent of heads of households (as a percentage of people employed in agriculture) had ejidal rights to land, down from 40 percent in 1940. Therefore, although an important absolute 
increase in the number of land reform beneficiaries occurred during those years, land reform recipients as a proportion of all workers in the agriculture sector had substantially declined (Sanderson 1984: 99).

Reinforcing this dynamic were three elements: (1) the lack of any more federal land to be redistributed (by 1970s ejidos occupied almost 55 percent of Mexico's agricultural land and 70 percent of its forests); (2) the expansion of cities and the consequent expropriation of agricultural lands to accommodate the urban population; and (3) the reluctance of governments to affect agribusiness, which still controlled most of the country's high-productivity lands, as well as water, infrastructure, credit, and subsidies (Barry 1995: 29, Bello 2009: 46, Hewitt de Alcantara 1976, Sanderson 1984: 99, 106, 130).

In the bimodal agricultural system between the 1940s and 1960s, peasant agriculture had three main functions: (1) enhancing rural communities' social reproduction through subsistence agriculture; (2) supplying local and national markets with cheap basic foods, mainly maize and beans, whose production largely relied on unpaid family labor; and (3) providing an underpaid seasonal labor force for commercial agriculture, increasingly controlled by large-scale agribusiness. Together, these factors contributed to subsidizing large-scale agriculture and the industrialization of the country (De Janvry 1981, Hewitt de Alcantara 1976).

Despite the critical role of peasant agriculture for the development of the country, most of the public funds invested in irrigation works, roads, technological inputs, and rural credit were focused on private entrepreneurs (Barry 1995: 29, Hewitt de Alcantara 1976, Sanderson 1984: 106). For instance, during the 1950s rural credit for private 
agriculture grew at an annual rate of 11 percent, compared to only 2 percent for the ejidal sector. Similarly, irrigation infrastructure quadrupled between 1940 and 1970; however, the large majority of beneficiaries were private landowners (Sanderson 1984: 111).

This lack of resources for campesino agriculture had further implications. "Restricted from the best land and from agricultural credit," explains Sanderson, "most ejidatarios were unable to take advantage of the advances in agricultural technology known collectively as the Green Revolution, which took place during the late 1950s and 1960s. Indeed, the productivity increases made by large private farms as a result of the Green Revolution further exacerbated differences in power and income and resulted in the alienation of good ejidal land (through rental) to farmers in the private sector with better access to capital" (1984: 106).

Furthermore, according to Hewitt de Alcántara (1976), those ejidos that did receive credit, public infrastructure, or any other kind of governmental aid, were closely regulated by federal agencies (e.g., the National Company of Popular Subsistence, CONASUPO). Those agencies determined what and how communities had to producegenerally cash crops using commercial seeds and agrochemicals — as well as the prices for their crops. These policies have a lasting legacy. In Chiapas, for example, more than 70 percent of the households cultivating native seeds today use fertilizers and herbicides, as do 95 percent of those cultivating commercial hybrids (Perales 2016: 274). Moreover, as a result of such regulation — which certainly granted peasants a protected market and guaranteed prices for their products - many communities prioritized the production of cash crops (e.g., coffee, sorghum) or livestock to the detriment of local environmental conditions and/or the nutritional needs of their own families (Sanderson 1984: 116; see 
also Jaffee 2014). It was calculated that by 1970, half of peasant households in the country were not producing enough to meet subsistence needs; only 16 percent were producing surpluses and these farmers were the primary beneficiaries of public investment in the previous decades (Eakin et al. 2014a: 136).

Another negative effect of the limited state support to campesino agriculture was peasant indebtedness. In an attempt to improve their agricultural productivity, or just to meet family needs, communities were forced to rely on local moneylenders for access to credit. In Los Altos of Chiapas, for instance, moneylenders charged interest rates as high as 5-10 percent a month (Rus 1994: 17). Also reinforcing peasant indebtedness was the increased role of coyotes, who squeezed communities by buying their production at very low levels below market prices, frequently in exchange for groceries. Terratenientes would also pre-pay peasants' harvests at lower prices when workers needed money for attending to family emergencies or financing a community celebration. ${ }^{6}$ As I will explain in later chapters, many of the campesino organizations that emerged in Chiapas in the mid-1970s had as one of their main objectives to break this circle of indebtedness and vulnerability. Indeed, promoting the creation of peasant collective production and credit associations among indigenous people was one of the original goals of Bishop Samuel Ruiz when he founded DESMI. ${ }^{7}$

Together, these factors helped to further decapitalize peasant agriculture and left communities deeply dependent on, and vulnerable to, external markets for complementing their subsistence agriculture. This situation was tolerable during the boom of commercial agriculture in the 1950 s and 1960s, because most communities still had minimally sufficient land for subsistence agriculture and to produce some surpluses 
for the market, the agro-export sector kept absorbing indigenous labor at a high rate, and the national market for basic foods (the main market for peasant production) was also expanding as a result of urbanization and industrialization (Hewitt de Alcantara 1976). However, this fragile equilibrium was abruptly disrupted in the 1970 s.

\section{The Crisis of Mexican Agriculture}

By the late 1960s, the annual growth of the Mexican agriculture sector had fallen from 6 percent to 1 percent (Barry 1995: 29). This was a result of the saturation of global markets, which were inundated with cheap surpluses produced by the highlyindustrialized and subsidized agricultural sectors of the U.S. and other developed countries - particularly Europe, Japan, and Australia, now recovered from the Second World War (see Bernstein 2016, Friedmann 2016, McMichael 2016a for an analysis of the surplus food regime of 1945-1973).

Adding to this global trend, the rapid pace of urban population growth- together with the displacement of food crops by livestock and feed grain production-outpaced the ability of peasant producers to supply food grains to the national market. It was during the 1970s that the Mexican government began to import cheap basic foodstuffs from the U.S. (Barkin 1987: 271-285, Barry 1995: 31, Hewitt de Alcantara 1976). Unable to compete with U.S. dumping prices for food grains, the government started to eliminate many of the guaranteed prices that had protected Mexican agriculture during the previous decades (Barkin 1987: 273, 284, Rus 2012: 40).

The industrialization of commercial agriculture, one of the achievements of Green Revolution policies, had also aggravated both the fiscal deficit of the Mexican state and the crisis of peasant agriculture. On one hand, the modernization of the agro-export sector 
had relied entirely on imported U.S. technology (i.e., machinery, seeds, agrochemicals, and technical assistance) (Hewitt de Alcantara 1976). This represented an increasing burden for Mexican finances due to the unequal exchange in global markets between industrial products and agricultural commodities (McMichael 2016b). On the other hand, the introduction of machinery and industrial inputs created a surplus labor force of rural workers who started to migrate to the cities and to the U.S. (Sanderson 1984: 130). For instance, Rus calculates that during the 1970s, between 2,000 and 4,000 seasonal workers from Los Altos (10-25 percent of the migrant labor force of the region) had lost their jobs in the maize fincas of central Chiapas as a result of both the use of industrial technology (agrochemicals, seeds, and machinery) and the elimination of price subsides for maize, which prevented landowners from expanding the production of this crop (2012: 40). Unemployment and rural migration, in turn, added pressure to the already rapid processes of urbanization and food imports from the U.S. (Barkin 1987: 272, 279).

This structural disequilibrium was exacerbated in 1975 when an international commodity-price crisis hit the agro-export sector, ${ }^{8}$ which accounted for more than 50 percent of all Mexican export revenues (Arslan Gurkan 2003, Barry 1995: 35, Peters et al. 2009, Rus 2012: 40). The import-substitution industrialization model that Mexico had successfully begun to develop in the 1950s also suffered from a fiscal deficit caused by the stagnation of the agro-export sector and the rapid increase in imports (industrial inputs, foodstuff, and other manufactured goods) (Cueva 1977: 184-200, Ros 1993: 3). ${ }^{9}$ Driven in part by the crisis of both the agro-export and industrial sectors, the Mexican government turned to the maquiladora economy and in 1965 established the first border industrialization program, which allowed mainly U.S. capital to produce goods in 
Mexico's border zone using cheap labor, free from any tariffs or restrictions on commodity movements (Harvey 2005: 98).

The government was able to delay for a few years the inevitable economic crisis due to the discovery of huge oil reserves in 1976, which happened in the context of the OPEC (Organization of Petroleum Exporting Countries) oil embargo and the high oil prices that resulted. By 1981, Mexico had become the fourth largest oil producer in the world, and oil exports displaced agriculture as the main source of revenues (Barbosa and Domínguez 2006: 81). This new flow of petrodollars was accompanied by cheap credit coming from private international investment banks and multilateral organizations such as the World Bank and the Inter-American Development Bank. Between 1972 and 1982, Mexico's foreign debt rose from $\$ 6.8$ billion to $\$ 58$ billion (Harvey 2005: 99 ; see Schatan 1998, Saxe-Fernández and Delgado 2001, and Goldman 2005 for excellent analyses of the role of the World Bank in the redistribution of petrodollars through tripartite credits among developing countries).

The oil and credit boom helped to finance a new, although ephemeral, wave of economic growth. Most of the new state investments went to the expansion of the public sector - mainly infrastructure, basic services, oil extraction and refining, and the nationalization of bankrupt private enterprises (Harvey 2005: 99). The government also re-engaged with agrarian reform and redistributed a considerable amount of average quality land among peasant communities (Sanderson 1984: 72). Particularly important was the creation of the Mexican Food System program (SAM) in 1980, a remarkably successful effort to raise per capita grain production through subsidizing credit, seed and fertilizer, technical assistance, and access to markets. The program also had the objective 
of improving food distribution among the most impoverished sectors both in the cities and the countryside. In just the two years of SAM's existence, Mexico reversed the downward slide in grain production and achieved national food self-sufficiency (Barry 1995: 40-41, Eakin et al. 2014a: 136).

The growth of the construction sector also helped to absorb part of the rural labor surplus that had been created by the agro-export crisis. In the case of Chiapas, one of the states with relatively important oil reserves, by 1980 due to infrastructure construction almost 17,000 new formal jobs were created (Thompson et al. 1988: 232). Many other former seasonal finca workers also started to migrate to the neighboring oil-rich states of Tabasco and Campeche to join the construction economy (Rus 2012: 41).

These new migratory dynamics, Rus notes, introduced important changes into the indigenous communities of Los Altos. Workers started to migrate to more distant places for longer periods, sometimes even for years. This was the time when the migration of whole indigenous families to peri-urban areas began. Additionally, these new jobs were mostly filled by those who spoke Spanish and were more able to relate to mestizo and urban populations. As a result, indigenous communities came to be increasingly populated only by non-Spanish speaking men, along with women, children, and elderly people. Moreover, these communities' subsistence agriculture was substantially complemented for the first time by money coming from non-agricultural activities. Rus suggests that these economic and demographic changes ended up breaking the corporatist model of government linked to the finca economy that had emerged during the years of Cárdenas (Rus 2012: 41). Suddenly, indigenous communities were more open to change. 
The 1970s were years of widespread instability and rapid change across the Mexican countryside. The post-revolutionary model of agriculture had reached its limits and the federal government could not offer an alternative to millions of impoverished peasants other than migrating to urban slums or the U.S. This was the socio-economic context in which many peasant organizations and guerrilla movements emerged across the country (e.g., Liga Comunista 23 de Septiembre, Partido de los Pobres, Asociación Cívica Nacional Revolucionaria, Movimiento de Acción Revolucionaria). The evolution of urban social movements, particularly the student movement, also shaped this political process. Many students who had survived the brutal repression of $1968^{10}$ fled the cities and founded guerrilla movements or joined the ranks of the many peasant organizations that began to emerge in the 1970s. In the case of Chiapas, it was in 1972 when the Fuerzas de Liberación Nacional (FLN, a clandestine group formed by students and professors in the Northern state of Monterrey in 1969) established the fledgling Núcleo Guerrillero Emiliano Zapata (NGEZ) in the Lacandón rainforest. Although the Mexican army assassinated all six of NGEZ's members in 1974, the FLN reorganized and sent a second group. Among them was Rafael Sebastián Guillén, a university professor in Mexico City, who years later would become the Subcomandante Marcos, one of the central leaders and the primary spokesman of the EZLN (see Cedillo 2010, 2008 for a comprehensive history of the FLN and its evolution into the EZLN).

\section{The Rise of Neoliberalism}

The wave of economic growth that Mexico registered during the 1970s—an annual rate of 7 percent, largely financed by the oil and credit boom—came to an abrupt end in August 1982, when the government announced that it had exhausted its hard 
currency reserves and defaulted on its foreign debt (Bello 2009: 40, Veltmeyer and Petras 1997: 15). According to David Harvey, Mexico's collapse was a direct outcome of the radical set of monetary policies that the U.S. Federal Reserve Bank had imposed in 1979 as a mechanism to alleviate the stagflation crisis of the U.S. economy. As a result, the U.S. nominal interest rate precipitously rose, reaching almost 20 percent in July 1981. Since the loans were designated in U.S. dollars, Mexico's debt service grew dramatically in only two years. Mexico was the first debtor country driven to the brink of insolvency as a consequence of the Volcker shock—named after Paul Volcker, chairman of the U.S. Federal Reserve under the governments of Carter and Reagan (1977-1989) (Harvey 2005: 23-29).

This was the beginning of the debt crisis, which would submerge the global South into the "lost decade," a period of zero or negative economic growth, dismantling of welfare states, and sharply higher poverty rates (McMichael 2016b, Veltmeyer and Petras 1997). Furthermore, the debt crisis also proved to be the mechanism through which a neocolonial regime, characterized by the mass transfer of surpluses from the periphery to the global North, was implemented (McMichael 2016b, Saxe-Fernández and Núñez 2001b, Schatan 1998). One effect of this political project, writes Harvey, "was to permit U.S. owners of capital to extract high rates of return from the rest of the world during the 1980s and 1990s. The restoration of power to an economic elite or upper class in the U.S. and elsewhere in the advanced capitalist countries drew heavily on surpluses extracted from the rest of the world through international flows and structural adjustment practices" (2005: 29). This modern system of accumulation by dispossession—which has its own distinct versions and mechanisms in developed countries — has been hidden by a 
neoliberal orthodoxy aiming to destroy the legitimacy of the welfare states that had emerged from the Second World War and the decolonization revolutions in the Third World (Chomsky 2013, Harvey 2005). Using the words of Noam Chomsky, the neoliberal project represents a "war on class" in which the owners of capital have successfully dismantled many of the restrictions to capital accumulation that were achieved by states and the working classes in previous decades (2013: 137).

The immediate implication of the debt crisis for debtor countries was the imposition by the International Monetary Fund (IMF) and the World Bank of so-called macroeconomic stabilization policies (budgetary austerity and deflation), and "structural adjustment" programs (trade liberalization, market deregulation, privatization of state enterprises, and downsizing of the state) (Veltmeyer and Petras 1997: 16). The objective was to roll back the state and redirect government expenditures toward the payment of debt service. "Thus was 'structural adjustment' invented," as Harvey puts it. In return for debt rescheduling, debtor countries were forced by "international powers to take on board the cost of debt repayment no matter what the consequences for the livelihood and wellbeing of the local population" (Harvey 2005: 29).

As a result of the imposition of this neoliberal doctrine, Mexico's interest payments on its debt, as a proportion of total government expenditures, rose from 19 percent in 1982 to 57 percent in 1988, while capital investments dropped from 19.3 percent to 4.4 percent (Bello 2009: 40). In the case of the agricultural sector, public investment fell by 76 percent during 1982-89. The effects of these measures were devastating for the popular sectors. During the same period, Mexico's per capita income decreased at a rate of 5 percent per year, and the value of workers' real wages fell 
between 40 and 50 percent (Lomnitz-Adler 2004: 47). By 1988, 20 percent of the workforce was unemployed and almost 40 percent underemployed (Bello 2009: 41).

This situation was replicated in most of the Latin American countries. By 1996, the region's total outflow of resources to the North in the form of interest payments on debt had reached U.S. $\$ 515$ billion. However, despite this massive transfer of surpluses, Latin American debt grew from $\$ 19.2$ billion in 1987 to $\$ 29.0$ billion in 1998 . This happened because debtor countries were forced to acquire new credits with the purpose of paying off accumulated debt service (Schatan 1998: 26, 32). Poverty rates soared as a result. Across the region, the number of households in poverty rose from 40 percent in 1980 to 62 percent in 1993 (Veltmeyer and Petras 1997: 16-19).

Together with fiscal austerity (elimination of price controls and subsidies, and reduction of social benefits and expenditures), the expansion of the raw materials-export sector was strongly encouraged by creditor countries and international institutions as a mechanism to generate revenues. Among indebted regions in the global South, Latin America registered the highest external debt service as a percentage of its exports: 54 percent in 1988. The figure was even higher for Mexico, at 75.2 percent (Veltmeyer and Petras 1997: 18). The implications of this transfer of capital from Latin America to the global North are even more disastrous if we take into account the material consequences, in terms of natural resources. The Chilean economist Jacobo Schatan calculates that between 1982 and 1996, Latin America's net transfer of natural resources in the form of raw materials produced for global markets was around 11 billion tons, of which 88 percent were minerals and oil (non-renewable resources), 3 percent fisheries resources (from fragile marine ecosystems), and 9 percent agricultural products (1998: 77-85). 
Simultaneous to the expansion of the Latin American export sector, imports of food, manufactured goods, and luxury items coming from the North, mainly the U.S., grew at an annual rate of 18.3 percent between 1990 and 1996 (Saxe-Fernández and Núñez 2001b: 118).

Trade liberalization, the privatization of state enterprises, and denationalization were also imposed on debtor nations as part of the IMF and World Bank structural adjustment programs. In 1986, as a precondition for receiving a new loan from the World Bank, Mexico joined the GATT (General Agreement on Tariffs and Trade), which further advanced the process of trade and investment liberalization. As a result, between 1982 and 1988 import tariffs were lowered from 50 percent to 20 percent, and the number of state-owned enterprises dropped from 1,155 to 285 . Along with these measures, the Mexican government promoted foreign investment in many economic sectors that had been previously protected (e.g., financial services, private education, newspaper publication) (Bello 2009: 41-42). By 1991 Mexico had received 13 structural and sectoral adjustment loans from the World Bank—-more than any other country in the world—and signed six agreements with the IMF (Barry 1995: 43).

The implementation of neoliberal policies intensified even more during the government of Carlos Salinas de Gortari (1988-1994), a U.S.-trained economist and politician who had ascended to the presidency through electoral fraud (Saxe-Fernández 2002). ${ }^{11}$ There were three key targets of structural adjustment programs during Salinas' government: (1) the privatization of strategic economic sectors (energy, railroads, highways, ports, banks, food distribution, land markets, telecommunications, chemical plants), which constituted the core of the Mexican economy; (2) the deregulation of the 
financial system and foreign direct investment; and (3) the negotiation of NAFTA (SaxeFernández 2002).

It was during the Salinas' sexenio (six-year government) when the maquila economy rapidly expanded along the northern border, establishing a new model of deregulated, highly-fluctuating, and feminized employment. In 1994 alone, employment in the maquila sector grew 20 percent (Harvey 2005: 101, Migration News 1995). Reinforcing the "maquiladorization" of the labor market was the dismantling_-not without popular resistance and state repression — of most public-sector labor unions, that resulted from the privatization of state-owned companies. The banks that had been nationalized in 1982 were re-privatized in 1990, and then most of them absorbed by foreign capital after 1994 (Harvey 2005: 101). The agri-food sector was also reformed and privatized, and the land market was opened to foreign direct investment. The negotiations of NAFTA concluded in 1992, the pact was barely ratified by the U.S. Congress in late 1993 , and on January $1^{\text {st }}, 1994$, the agreement was enacted. By the end of his mandate, Salinas de Gortari had successfully completed the agenda of structural adjustment that accompanied the World Bank and IMF conditional loans.

But these were not the only "achievements" of the Salinista neoliberal agenda. The wave of mass privatization had helped to swell the fortunes of an upper class closely linked to Salinas de Gortari. In 1994, Forbes Magazine's list of the richest people in the world revealed that Mexico's economic restructuring had produced 24 billionaires. Of these, at least 17 had benefited from buying former state-owned companies at fire-sale prices (MacLeod 2004: 99-100 in Harvey 2005: 103). Also in 1994, an estimated 800,000 undocumented Mexican migrants entered the U.S., only a fraction of the 1.8 million who 
had tried to cross the border that year. Only one year later, in 1995, the number of people attempting to enter the U.S. without documents had risen 44 percent (Migration News 1995).

\section{The World Bank and the "Modernization" of Mexican Agriculture}

A good example of the World Bank's policy conditions are the two sectoral adjustment loans for the "modernization of agriculture" that Mexico signed in March $1988^{12}$ and May $1991^{13}$ (World Bank 1988, 1991, 1994). The conditions included the elimination of required import permits for more than a dozen food products, the reduction of agricultural tariffs, and the cancellation of price controls on a range of basic food items, among them price guarantees for maize. The structural adjustment program also required the gradual dismantling and privatization of state-owned companies and government agencies that formerly supplied credit, insurance, technical assistance, marketing services, and subsidies for irrigation, electricity, and chemical inputs (the Mexican Fertilizer Company, FERTIMEX; the National Seed Producing Company, PRONASE; the National Company of Popular Subsistence, CONASUPO) (Barry 1995: 43-46, Yuñez-Naude 2003, World Bank 1988, 1991: i, 1994: iii).

Complying with another of the World Bank's policy recommendations (Heat 1990: 55-58), in 1991-92 the Mexican government reformed the national agrarian law and amended Article 23 of the Constitution. The aim of this reform was to accelerate the capitalist transformation of the countryside through the creation of active land and labor markets that would promote the "efficient" allocation of resources and improve agricultural investment (Appendini 2001, Bello 2009: 46, de Ita 2006: 151, Heat 1990). According to Ana de Ita, the World Bank's recommendations "were oriented toward 
eliminating the differences between private and ejidal property, with an emphasis on the security of land tenancy and the individualization of the collective functions of the ejido and its destruction as a unit of production and organization" (2006: 151). The government also reformed Article 27 of the Constitution, which for the first time opened up the ejidal sector to foreign direct investment and eliminated the prohibition on associations between foreign investors and ejidatarios. Crucially, the reform also abolished the constitutional obligation of the government to redistribute lands to landless peasants, which had been one of the major victories of the Mexican Revolution (de Ita 2006: 151-152, van der Haar 2007: 488). In less than a decade, a World Bank-mandated set of structural programs had put an end to eight decades of agrarian reform and opened the way for the privatization of ejidal land. These reforms laid the groundwork for NAFTA's agricultural chapter.

“Maize is Not More Business": NAFTA, Food Dependency, and Peasant

\section{Agriculture}

Mexico's food self-sufficiency ceased to be an objective of Mexican governments in 1982, when President Miguel de la Madrid (1982-88) closed the doors of the fledgling Mexican Food System program (SAM). Since then, the privatization, liberalization, and integration of the Mexican agricultural sector into the U.S. economy have been the goals of neoliberal policies. The erosion of food sovereignty, reflected in the increased dependence on food imports from the U.S. since NAFTA, is one effect of the more than three decades of "neoliberal modernization" of the Mexican countryside.

In the process of neoliberalizing the agricultural sector, the Mexican government has abandoned peasant agriculture. As Eakin et al. assert, "[t]he underlying assumption appears to be that commercial 'capitalist' farms are the only farms with the capacity to 
contribute to Mexico's food and agricultural needs" (2014a: 137). The long-term deprioritization of the campo has been particularly painful for those in the countryside whose opportunities to produce for the market, or even practice subsistence agriculture, have diminished. According to De Janvry et al., in 1995 this vulnerable group of peasant farms accounted for up to 90 percent of the ejidal sector (1995: 1350). The neoliberal modernization of the agricultural sector has excluded many of these families and forced millions of peasants either to shift to the production of non-traditional crops (fruits and vegetables, the higher valued crops favored by NAFTA, or even drug crops), join nonagricultural labor markets in the cities, or to migrate to "El Norte" to work in the agribusiness sector there. As Walden Bello puts it, "finding eking out a living from agriculture increasingly impossible, Mexico's peasantry simply moved to the United States" (2009: 50).

NAFTA's agriculture chapter came to reinforce these trends. It advanced the liberalization and privatization of food commodity chains, accelerating their integration into the market economy and the neoliberal agri-food system (Appendini 2014: 2, see Bernstein 2016, McMichael 2016, and Friedman 2016 for an analysis on the neoliberal food regime). Import licenses were eliminated for almost all of the basic crops and food staples previously protected by CONASUPO. Only for barley, beans, maize, and milk powder - which were considered "sensitive foods"-were tariff rate quotas established (these import limits lasted 10 years for barley and 15 years for beans, maize, and milk powder). Even so, during years in which local production could not supply the national market, the government allowed imports over the quotas. This was the case for yellow 
corn for livestock consumption and industrial use in 1996, 1998, and 1999 (Yuñez-Naude 2003: 9-11).

According to Timothy Wise's study of the effects of American agricultural dumping under NAFTA on Mexican producers, U.S. exports of eight important foods to Mexico increased between 159 and 707 percent from 1993 to 2005. Whereas Mexico was self-sufficient in grain in 1963 and still 80 percent self-sufficient in 1990, by 2005 the country imported 42 percent of its total food consumption, mostly from the U.S. Moreover, Wise emphasizes, most of these exports constituted agricultural dumpingthat is, export prices below production costs. Due to farm subsidies and other policies, their sale prices in Mexico undercut even U.S. farmers' costs of production by between 12 and 38 percent (Jaffee 2014: 272-3, Wise 2009: 3).

However, the dismantling of import licenses and guaranteed prices for food staples was only one aspect of NAFTA. The privatization, concentration, and transnationalization of entire food chains are the core aims of NAFTA's agri-food measures. As Appendini documents for the case of the maize-tortilla chain, global agribusiness corporations have entered and increasingly dominated the Mexican domestic market as suppliers (of seed, fertilizers, machinery, and equipment), grain traders, and food processors (2014: 3).

This process has triggered profound regional and organizational changes in the national production of maize. "At the start of the 1990s," writes Appendini, "maize was primarily a crop of the peasant farmers... Central and southern Mexico, the primary regions of maize consumption, were also the primary locations of maize production" (2014: 5). However, she continues, this situation radically changed with the policy 
reforms and international market integration promoted in the context of NAFTA. Although in 2009 Mexico was still producing up to 93 percent of its white maize (for human consumption), the imports of yellow corn (for livestock consumption and industrial use) coming mainly from the U.S. had reached 75 percent of national consumption (Appendini 2014: 4). Wise points out that Mexican corn import dependence grew from 7 percent before NAFTA to 34 percent in 2006-08; this is a 413 percent increase of U.S. dumping exports to the country, causing a 66 percent fall in real corn prices and costing Mexican producers a total of $\$ 6.5$ billion in lost income over that period (Wise 2009: 3).

Another important change, which reflects the decline of peasant participation in the national maize market, is that today between 40 and 50 percent of national maize production comes from the largely-irrigated states of the North. Sinaloa alone contributed more than 20 percent of national maize production between 2006 and 2008, in contrast with only 6.9 percent between 1985 and 1989. As a consequence, the production of the central states and Chiapas has been relegated to second place, dropping from 39 percent for the period $1985-89$ to only 28 percent in 2006-08; a high proportion of this maize is grown on irrigated lands (Appendini 2014: 5-6).

In a study comparing maize production for the market in Sinaloa, Mexico State, and Chiapas, Eakin et al. found that:

CONASUPO's disappearance in the late 1990s left most of the smallholder sector in central and southern Mexico without a market for their harvests. In contrast, Sinaloan farmers switched easily to commercial buyers. Today they sell almost exclusively to large commercial warehouses, who then sell the grain to 
commercial buyers (Cargill, Maseca, Minsa, Sabritas) for flour processing for commercial maize tortillas or for other industrial uses (livestock feed, snack foods and cereal). Two Mexican maize flour processors Maseca and Minsa [both companies with American capital] now control 90 per cent of the processed maize flour market...Sinaloan grain and Sinaloan maize flour has penetrated wholesale markets across Mexico (2014a: 144).

The central role of irrigated agriculture on high-quality land in the northern states, which accounts for about 18 percent of annual maize area and more than 40 percent of national production for the market, contrasts with the fact that around 85 percent of the farmers planting maize in the country do so in fields of less than five hectares and under rainfed conditions (Perales 2016: 272).

However, despite this lack of access to production inputs and to the market, peasants continue to produce maize. Data from two agricultural censuses show a stable number of Mexican households planting maize: 2.75 million in 1991 and 2.83 million in 2007 (Perales 2016: 272). This is seemingly a paradox: Why do peasants continue to produce maize if there is not a market for it? "For the peasant sector," writes Perales, "maize is primarily food security with very low or nil net income, and it seems that highest yield is not the objective. It is not uncommon to hear farmers state that 'maize is not a business;' nonetheless, abandonment of maize production seems to be very low, even after NAFTA" (2016: 272; see also Perales 1998, and Eakin et al. 2014a).

After decades of neoliberal reforms aiming to dismantle state agencies and privatize national markets, Mexican peasant food security now relies more than ever on subsistence agriculture, on alternative labor markets, and/or on remittances coming from 
family members working in the U.S. According to Rivera et al., by 2007 only around 25 percent of rural households' income came from agricultural activities (12 percent from agriculture, 3 percent from livestock, and 12 percent from agricultural seasonal work as jornaleros) (2015: 65). The structural vulnerability of peasant families is reinforced in a context in which households lack adequate land and production inputs for agriculture, environmental degradation has limited the productivity of already poor-quality land, food-price crises are frequent, and agricultural labor markets constantly change as a function of global trends. As a consequence of the privatization and transationalization of Mexican agriculture under NAFTA, "the Mexican state ceded its sovereignty over food policy and has shown limited capability or willingness to deal with the challenges of the food crisis in later years by Mexican consumers. The present context of uncertainty in the international grain market and negative climate effects on domestic production underline the vulnerability of the food supply after two decades of the neoliberal maize regime" (Appendini 2014: 3).

"NAFTA is a Death Certificate for the Indian Peoples of Mexico": The

\section{Zapatista Agrarian Reform}

These are the words of Subcomandante Marcos in an interview on January $4^{\text {th }}$, 1994, three days after the uprising of the EZLN in Chiapas, and the very same day that NAFTA was enacted. For these neo-Zapatistas, the neoliberal reforms that were implemented in the lead-up to NAFTA resemble the wave of dispossession, privatization, and denationalization that characterized the regime of Porfirio Díaz (1876-1910). Just like the original Zapatistas of the Mexican Revolution, the EZLN took up arms in the name of defending peasant agriculture. 
The First Declaration of the Lacandón Jungle—-the 1994 Zapatista declaration of war-states the demands of the movement: "work, land, housing, food, health care, education, independence, freedom, democracy, justice, and peace" (EZLN 1994a). Accompanying this First Declaration, the EZLN proclaimed its Ley Agraria Revolutionaria (Agrarian Revolutionary Law), which states: "the struggle of poor peasants in Mexico continues to claim land for those who work it. After Emiliano Zapata and against the reforms to Article 27 of the Mexican Constitution, the EZLN takes up the just struggle of rural Mexico for land and liberty." The Zapatista law established that "all tracts of land that are more than 100 hectares of poor quality and fifty hectares of good quality will be subject to revolutionary agrarian action"- that is, expropriation (EZLN 1994b). Communal lands, ejido lands, or lands held by cooperatives were exempted from this decree. In accordance with this law, the EZLN occupied over 50,000 hectares of land during the first six months of 1994, and by the end of the year it declared the existence of more than thirty autonomous municipalities (Harvey 1998: 2, Klein 2015: 101). It is estimated that the EZLN today controls about 60,000 hectares of occupied private finca land (van der Haar 2007: 491-92).

According to Gemma van der Haar, this process established the basis of the unprecedented wave of land occupations that followed in the next few years across Chiapas. The first occupations had been carried out by the EZLN in the immediate area of conflict. After mid-1994, however, occupations spread to other regions of the state "as peasant organizations representing the whole political spectrum seized the opportunity to obtain land" (van der Haar 2007: 490). Villafuerte et al. calculate that there were over 1,700 occupations affecting nearly 148,000 hectares of land. In some municipalities, such 
as Altamirano in the eastern region of the state, the occupations covered more than 80 percent of the total area of private properties over five hectares (van der haar 2007: 490, Villafuerte Solís et al. 1999: 134, 354). This process of land occupation was, in the words of van der Haar, "a way of pushing land reform beyond its previous limits. Through the occupations peasant groups, many (although not all) of which constituted the base of the EZLN, gained access to land that they had often unsuccessfully tried to claim through legal means. One could say that peasant groups took the process of land redistribution beyond the point at which the Mexican State had left (or tried to leave) it in 1992" (2007: 491).

In response to these land occupations, the Mexican government was forced to open "a new episode of land redistribution in Chiapas, belying in practice the "end to land reform' that had been so triumphantly declared in 1992" (van der haar 2007: 491). Under the Agrarian Accords - an ad-hoc procedure for regulating those expropriations, lasting from 1995 to 1999 - the government granted title to about 240,000 hectares to peasant communities, most of them in the form of ejidos. To this number must be added the 60,000 hectares now controlled by the EZLN, who refused to participate in the Agrarian Accords (2007: 491). Thus, by the end of 1999, almost 300,000 new hectares of land were now in the hands of peasant communities. This was just the beginning of the Zapatista movement.

Similarly to the years of the Porfiriato, there is today a widespread idea among political and intellectual elites that indigenous communities are merely an obsolete actor that impedes the modernization of Mexican agriculture (Paz 1994, Salinas de Gortari 1994). However, this conceptualization can be easily refuted. Indigenous communities, as 
I have tried to demonstrate throughout this chapter, are among the members of Mexican society who know best the meaning of market liberalism and, using Polanyi's words, the perils of a disembedded market economy. For centuries, indigenous communities have experienced first-hand the dynamics of capital accumulation that come with agro-export economies and globalized commodity markets. As Barry puts it in the context of the EZLN uprising, "with the coming of free trade, they saw a series of economic and social reforms supposedly designed to modernize agriculture...A century-long history in Chiapas of producing timber, henequen, cotton, sugar, and coffee for the international market gave little reason to hope that increased international integration would result in a brighter future" (1995: 158).

The increased sense of desperation and deprivation among peasant communities caused by economic crises, neoliberal policies, and the cancellation of agrarian reform helped to spark the EZLN rebellion. Polanyi's concept of the double movement accurately reflects this dynamic: against the workings of global markets and "the impossible pressures of a self-regulating market system, [a] protective countermovement had to happen to prevent the disaster of a disembedded economy" (Block in Polanyi 1944: xxviii). The following chapters examine closely the protective countermovement that was born in Chiapas in 1994, with an emphasis on the emergence and development of the agenda of indigenous food and seed sovereignty in the central region of Chiapas. 


\title{
CHAPTER THREE
}

\section{CHIAPAS: POVERTY, LOW-INTENSITY WAR, AND ZAPATISTA AUTONOMY}

\author{
We are the product of 500 years of struggle. \\ EZLN, First Declaration of the Selva Lacandona, 1994 \\ Never again a Mexico without us. \\ EZLN Comandanta Ramona, Mexico City, 1996
}

\section{A Postcard from the Central Plaza of San Cristóbal de las Casas, Chiapas}

It is six o'clock in the morning at the end of February 2016. This is the usual cold and foggy winter morning in Los Altos of Chiapas. Despite it being so early, the place is quite active and full of indigenous women and children who, barely covered by their wool rebosos and plastic sandals_-some of them barefoot—are selling atole, tamales, arroz con leche, and pan dulce, the typical breakfast foods consumed by millions of working-class people across the country.

Most of these women and children are Chamulas, Tsotsil indigenous people from the neighboring municipality of Chamula. Some of the foods they are selling for only 5 pesos-42 cents (U.S.) in that morning, 26 cents today, after the most recent devaluation of the Mexican peso in January 2018 - are self-produced, but others were distributed to them earlier in the morning. For many of those women and children, breakfast foods are only the first merchandise they will sell during the day. After ten o'clock or so they will switch to handicrafts, flowers, traditional sweets, cigarettes, elotes cocidos, and tortillas. Throughout the day, indigenous male vendors will join with ice-cream carritos and wheelbarrows carrying heavier commodities, generally seasonal products such as fruits, 
vegetables, nuts, and seeds. As I discovered during my eight month-long stay in San Cristóbal de las Casas, the workday for many of these people can last up to 12 or more hours. Informal street commerce is a busy economy that does not sleep, and one can find multitude of indigenous vendors-including children who are drinking Coca-Cola in order to stay awake - even at midnight, when the buyers are tourists visiting bars. The plaza is alive all day long and almost all night.

Anyone who has visited San Cristóbal de las Casas would recognize this vignette. This multitude of impoverished, informal vendors is the first encounter most visitors have with the indigenous world of Los Altos of Chiapas. Those activists who have visited Zapatista communities would perceive this image as a reminder of the conditions of extreme poverty and exploitation that gave life to the Zapatista movement in the 1980s. Some of them, the most enthusiastic, would even affirm that for Zapatista communities these conditions of poverty are part of the past. For me, this quotidian image illustrates the potential of the Zapatista movement and its struggle for justice and indigenous development, but it also indicates the persistence of a colonial system of social stratification that is deeply rooted in Mexican society. To what extent has the Zapatista movement managed to break this colonial inheritance? What does it imply to be an indigenous person in Mexico? What does mean to be a Zapatista? These are some of the questions that I will explore in this and the following chapters.

This chapter introduces the area in which I conducted this research and situates it within the context of the Zapatista movement and the low-intensity war. As I will discuss 
in the following pages, extreme poverty, social exclusion, and state violence continue to be a central part of the everyday life of indigenous people in Chiapas. However, since the Zapatista uprising in 1994, and particularly after the reorganization of the EZLN in 2003, a new model of community-driven development has emerged as an alternative for those indigenous communities. Although the costs and implications of the Zapatista strugglemainly state repression, economic hardship, and divisions between supporters and nonsupporters - have imposed new burdens and responsibilities on indigenous communities, the movement has been successful in giving indigenous people a central voice in the power equation that today governs the state of Chiapas.

In the first part of this chapter I briefly contextualize myself in the Zapatista world. The second section introduces the study region and the communities that participated in this ethnographic research. I also present official data showing the conditions of poverty and social inequality that prevail in indigenous and peasant communities in the region. The third section focuses on the Zapatista struggle for indigenous autonomy and explores the implications and achievements of this alternative model of development. This analysis sets the stage for exploring DESMI's Guardians of Mother Earth and Seeds project.
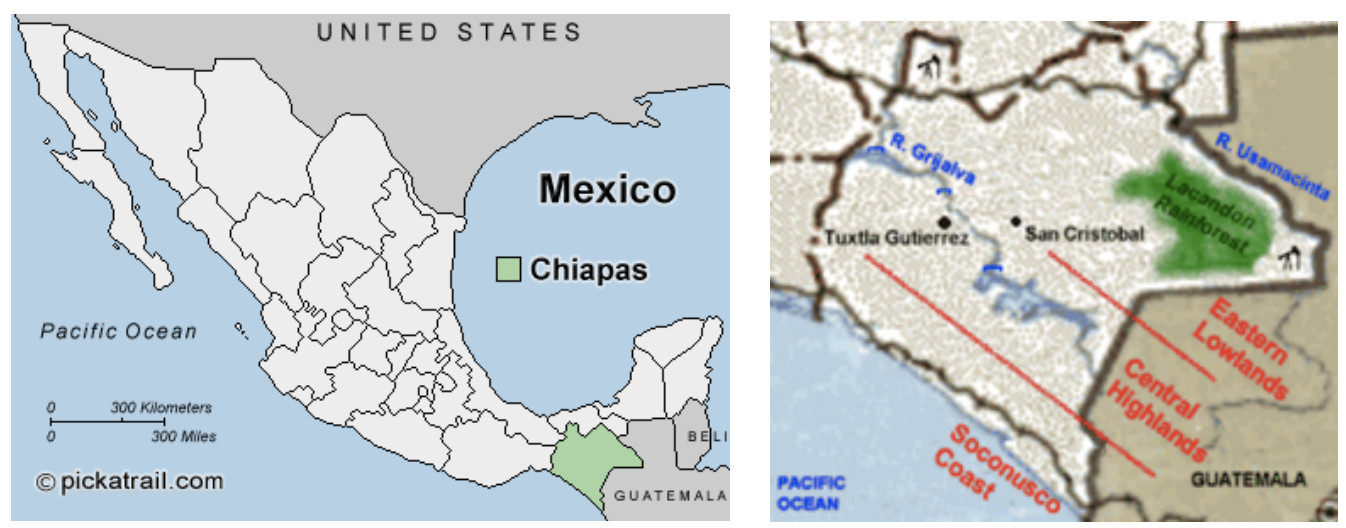

Figure 1. Chiapas, Mexico. Map on right reprinted from Homer-Dixon 1995. 


\section{My First Encounter with Zapatista Communities}

I was 17 years old when I first visited Chiapas. It was the summer of 1998, just a few months after the paramilitary group Paz y Justicia (Peace and Justice) had assassinated 45 indigenous people, most of them women and children, who were attending a prayer meeting in Acteal, a small Tsotsil community in the municipality of Chenalhó, in Los Altos of Chiapas. The victims were members of "Las Abejas," an indigenous pacifist group that supported the EZLN (Ramírez Cuevas 1997, Las Abejas 1997).

Since the uprising in 1994, thousands of civilian groups from many different parts of Mexico and other countries around the world had arrived in Chiapas in an attempt to support the Zapatista movement (see Barmeyer 2009: 136-155, Ronfeldt et al. 1998, Rosset et al. 2005). I had come with a student solidarity brigade that was organized by my university and the Fray Francisco de Vitoria Catholic Center of Human Rights in Mexico City. We visited Polhó, a Zapatista community of refugees who had been displaced by paramilitary violence, located a 20-minute walk from Acteal.

The dynamic of these solidarity brigades was very simple: we gathered food, clothes, medicines, and money in Mexico City to donate to the communities, and then traveled to Chiapas and stayed on a Zapatista community for two or three weeks. Once there, we helped with any kind of work the community needed: building latrines, painting a school, classifying books, or discarding expired medicines that people from the cities had donated. Most of the time we spent just playing with the children and organizing our own collective activities such as cleaning our dorms, cooking, or going to the river to 
take a bath. The truth is that we were not "doing a lot" there. The main objective of our visits was simply "to be present" in those communities. This was because neither the military nor paramilitary groups would attack the communities while civilian brigades like ours were there. Many people in the communities would say, half-joking and halfseriously, that the life of someone from Mexico City or any other foreigner had much more value than the life of an indigenous person. In any case, our visits were always happily welcomed by the residents of these autonomous communities because they provided a break from the everyday dynamics of low-intensity war in the state.

That first visit to Chiapas was one of the most intense experiences of my life. It was the first time I had visited an indigenous community, used a latrine, or walked across the mountains under a heavy rainfall that turned the trail into deep mud. I learned that most indigenous girls in non-Zapatista communities married before they were teenagers and that they immediately began to have children. I also discovered that drugs, alcohol, and prostitution were forbidden in Zapatista-controlled territory even before the armed uprising in 1994, and that this had helped considerably to reduce violence and sexual assaults within communities. I never before had visited a refugee camp, prepared an emergency backpack because there were rumors that a paramilitary group could attack the community in the middle of the night, or answered hostile questions from soldiers at the multiple military checkpoints through which we had to pass in the 90-minute trip from San Cristóbal de las Casas to Polhó. The low-intensity war was there, and I could almost breathe it.

However, the deepest impression for me was to feel, even as an outsider - almost 
a tourist - the pervasive conditions of state violence and extreme poverty in which these indigenous communities were living. I came to understand the meaning of the First Declaration of the Selva Lacandona, which explained the reasons why the EZLN had taken up arms a few years ago: "We have nothing, absolutely nothing, not even a roof over our heads, no land, no work, no health care, no food nor education...nor is there peace nor justice for ourselves and our children. But today, we say ENOUGH IS ENOUGH”(EZLN 1994a).

During my college years I visited Zapatista territory many other times. I returned to Polhó and Acteal in Los Altos, and also traveled to northern Chiapas and stayed in Roberto Barrios. Throughout this period I was able to see how Zapatista communities were transforming themselves. Despite the multiple conflicts and divisions that had emerged within these communities after years of low-intensity war, those who remained committed to the movement had become much more confident about their own struggle. The priorities of the EZLN had also started to shift from merely surviving the war to actually governing the territories it controlled. Community members were talking about the importance of strengthening the incipient Zapatista educational system, and perhaps, one day, they would even have their own hospitals.

The last time I joined a student brigade was in December 2002. Coincidentally, the following year the EZLN announced that there would be important changes in the organization and government of the Zapatista territories and that the relationship with civil society would be substantially modified. Communities needed, the EZLN said, to focus on building their autonomy (EZLN 2003). The EZLN was moving toward the 
construction of its autonomous government, which meant a reduced reliance on outsiders, such as NGOs and civil brigades, and an emphasis on indigenous, local resources with a corresponding rejection of the Mexican state's neoliberal policies. This chapter explores this transition and what indigenous autonomy means for Zapatista communities.

The next time that the EZLN launched a massive public demonstration was a decade later, on December 21, 2012, when almost 50,000 Zapatistas marched in silence in five different cities of Chiapas (Aragón 2012, Bellinghausen 2012, Molina 2013). The march was planned to coincide with the last day of the $13^{\text {th }}$ Baktún —a Baktún is the longest cycle in the ancient Mayan calendar-symbolizing a "new age" of the movement (Koman Ilel 2012). This time the objective was to announce to civil society that the EZLN was ready to show the world what the Zapatistas had built in almost 30 years of indigenous struggle. In a very short communiqué published that same day after the march, the EZLN said: "Did you hear it? It is the sound of your world crumbling. It is the sound of our world resurging. The day that was day, was night. And night shall be the day that will be day. Democracy! Liberty! Justice!” (EZLN 2012).

\section{Poverty, Ethnicity, and Gender}

Chiapas is the poorest state in Mexico. Among the country's thirty-two states, it ranks lowest on the Human Development Index - the HDI, which encompasses health, education, and income - at 0.667 (similar to Gabon, in Africa), far behind the national average of 0.745 (UNDP 2015: 6). This is an overwhelmingly rural state with 70 percent of its 118 municipalities, and 51 percent of its population of 5.3 million, classified as rural. The state government estimates that 30 percent of the population lives in conditions 
of extreme poverty, and another 25 percent live in poverty (see Table 2) (Chiapas 2016, IICA 2012).

But poverty and social exclusion in Chiapas are not equally distributed among the population. Ethnicity and gender are two key categories shaping social stratification in the state. With its 12 indigenous groups encompassing 28 percent of its population, Chiapas is the third most indigenous state in the country (INEGI 2016). The distribution of poverty closely corresponds to the areas with the highest indigenous population (see Figures 2A and 2B). For instance, the three municipalities with the worst HDIChamula, Mitontic, and Zinacantán—are located in the Tsotsil area of Los Altos of Chiapas, the most indigenous region in the state (UNDP 2014: 44).

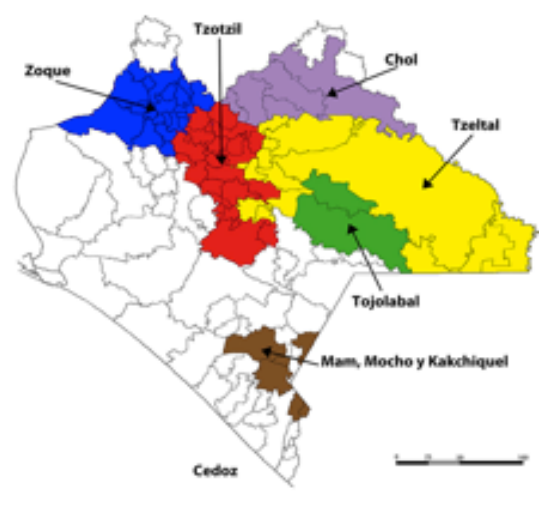

(A)

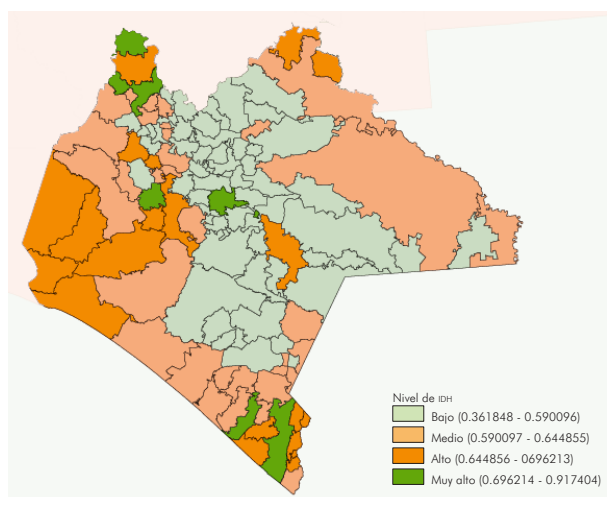

(B)

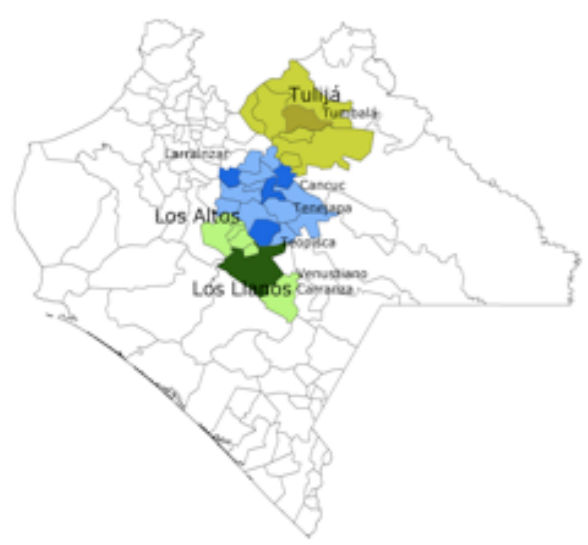

(C)

Figure 2. (A) Main Indigenous Groups in Chiapas (reprinted from CEDOZ 2018b); (B) Human Development Index at the Municipal Level (reprinted from UNDP 2014: 44); (C) Area of Study, by Regions and Municipalities (author's elaboration). 
The relationship between poverty and ethnicity is represented in Figures $\mathbf{2 A}$ and 2B. The former shows the distribution of the main six indigenous groups in the state, and the latter presents Chiapas's 118 municipalities according to their HDI. The areas in light gray in Figure 2B are those with the lowest HDI, and they correspond to the zones which historically have contained the large majority of indigenous people in the state ${ }^{1}$ (see Nations and Nigh1980: 2-3). These indigenous communities constituted the main source of labor for the finca economy from the colonial period until the mid-1970s, when an international crisis precipitated the collapse of the Mexican agro-export sector (see Chapter 2).

Contemporary indigenous migration to the tropical rainforest (Selva Lacandona) in the east of Chiapas (see Figure 1) became a systematic phenomenon only in the 1940s, when population growth and land scarcity in Los Altos and North of the state forced thousands of Tseltal, Tsotsil, and Cho'l indigenous people to try to find new land in the inhospitable Selva (Nations 1980: 2-3). Until the 1960s, the Selva Lacandona-614,000 hectares or 1.5 million acres — was mostly inhabited by a very small indigenous group called the Lacandones (only about seventy families). However, due to several waves of colonization, the population in the Selva rose precipitously from 1,000 in 1950, to 100,000 in 1980, to 150,000 in 1990 (Barmeyer 2009: 30, 37, de Vos 1995: 348-355). The relatively large amount of available land and resources in the Selva Lacandona, together with the development of organizational institutions relatively autonomous from the state due to its physical isolation (Barmeyer 2009: 31-34), might explain why this area, despite being overwhelmingly inhabited by indigenous people, registers higher 
levels of development than Los Altos or the North regions. Furthermore, it was in the Selva, among the newly formed indigenous communities, where the EZLN was born in 1983 (Barmeyer 2009: 30, 37, Cedillo 2010, Harvey 1998). The continuous migratory character of those communities allowed them to keep communication between the new settlements and the communities of origin, which may account for the rapid spread of the Zapatista movement across most of Chiapas's indigenous areas (see Figure 7) (Barmeyer 2009, de Vos 2002).

The study region is presented in Table $\mathbf{1}$ and Figure 2C. It includes six municipalities, four of them with an indigenous majority: San Andrés, San Juan Cancuc, Tenejapa, and Tumbalá; and two municipalities with a large mestizo population, who are the dominant ethnic group in Mexico: Teopisca and Venustiano Carranza. These six municipalities are located within three regions: Los Llanos, Los Altos, and Norte-Tulijá. All six municipalities are among the poorest in the state, and most of the communities that comprise them strongly rely on subsistence agriculture for their social reproduction.

Table 1. Area of Research: Regions, Municipalities, and Ethnicity

\begin{tabular}{|c|c|c|}
\hline $\begin{array}{c}\text { Region and Municipality } \\
\text { (Predominant Indigenous Groups) }\end{array}$ & $\begin{array}{c}\text { Number of Communities } \\
\text { in this Study }\end{array}$ & Ethnicity \\
\hline Los Altos Region (Tseltal Tsotsil) & & Tsotsil \\
\hline San Andres Larrainzar & 25 & Tseltal \\
\hline San Juan Cancuc & 10 & Tseltal \\
\hline Tenejapa & 6 & Mestizo \\
\hline Teopisca & 2 & Ch'ol \\
\hline Norte Tulijá Region (Tseltal-Ch'ol) & 12 & Mestizo \\
\hline Tumbalá & & \\
\hline Los Llanos Region & 1 & \\
\hline Venustiano Carranza & 56 & \\
\hline Total & &
\end{tabular}


According to federal government data, access to basic services, health, education, and labor markets differs considerably between indigenous people and mestizos (INEGI 2010, 2016). Table 2 presents demographic data and shows the level of social marginalization for the six municipalities encompassed in the area of study, as well as for the state of Chiapas, and for Mexico. It is worth noting that the four indigenous municipalities present "very high" levels of social marginalization, in contrast to the two mestizo municipalities which are classified as having "high" marginalization. The differences between indigenous and mestizo groups are also highly visible if we look at housing conditions. As Table 4 shows, access to basic services such as piped water and sewage is considerably lower in indigenous municipalities than in mestizo communities. Concrete roofs, gas stoves, refrigerators, and radios are more limited in indigenous households as well.

Social inequality is even more visible if we look at the differences between genders. As Table 3 illustrates, over 40 percent of indigenous women do not speak Spanish, in contrast to less than 30 percent of indigenous men. This percentage can be as high as 85 percent of women in some areas, such as the Tseltal municipality of San Juan Cancuc in the Los Altos region. Illiteracy is also considerably higher among women than men, and this gap is wider in indigenous communities.

Likewise, land ownership is overwhelmingly a male right, and more than 86 percent of landholders - both ejidatarios and comuneros — in the state are men. Within indigenous communities, male control over land reaches almost 100 percent of the territory (see Table 5) (INEGI 2010). This gender inequality in land distribution is a 
direct outcome of federal agrarian policies. According to the post-revolutionary Ejido Law of 1920, the federal government granted ejido rights to the male heads of household. Women were granted equal rights to ejido membership only in 1971; however, most of the land continues to be inherited and distributed among men. "In practice," writes Klein, "most ejidatarios continue to be men and, in most of rural Mexico, land is either inherited by the oldest son or divided among the male children. The argument is that a woman will marry and live with her husband, and therefore [does] not need land of her own. Even by this logic, many women are excluded, such as those who are unmarried or widowed" (2015: 94).

Participation in the labor market also remains predominantly a male activity, and only 21 percent of women in the state are employed (see Table 6). It is important to highlight that although an average of 70 percent of men participate in the labor market, household income is still very low. As much as 45 percent of the state's population, and about 90 percent of indigenous workers (most of them concentrated in the primary sector), receive the equivalent of the national minimum wage or less ( 80 pesos a day, or U.S. \$4), in contrast to only 8.8 percent of workers at the national level. Moreover, this percentage includes people who work without a salary—for instance, in exchange for housing or food -including many indigenous women working as maids or nannies for mestizo families in the cities (INEGI 2010). According to the federal government, the large majority of the population in the country working without a salary are indigenous people, and among them women predominate (INEGI 2016). The words of the Zapatista Comandanta Ester aptly describe this situation of social inequality: "We are oppressed 
three times over — because we are poor, because we are indigenous, and because we are women" (EZLN 2001). This is an initial, overall picture of Chiapas. However, a more detailed image shows a complex and contrasting scenario where competing models of development are reshaping the power relationships in the state.

Table 2. Demographic Data: Social Marginalization and Ethnicity

\begin{tabular}{|c|c|c|c|c|c|c|c|c|c|c|c|}
\hline \multirow[t]{2}{*}{$\begin{array}{c}\text { Region, } \\
\text { municipality, } \\
\text { and ethnicity }\end{array}$} & \multirow[t]{2}{*}{ Population* } & \multirow[t]{2}{*}{$\begin{array}{c}\text { Level of social } \\
\text { marginalization* }\end{array}$} & \multicolumn{2}{|c|}{$\begin{array}{c}\text { Population speaking } \\
\text { indigenous language** }\end{array}$} & \multicolumn{3}{|c|}{$\begin{array}{l}\text { Population speaking } \\
\text { Spanish (percent) } * *\end{array}$} & \multicolumn{3}{|c|}{$\begin{array}{l}\text { Population with access } \\
\text { to health services** } \\
\text { (percent) }\end{array}$} & \multirow[t]{2}{*}{$\begin{array}{c}\text { Child } \\
\text { mortality** } \\
\text { (percent) }\end{array}$} \\
\hline & & & Total & Percent & All & Male & Female & All & Male & Female & \\
\hline Los Altos & 661,941 & Very High & 449,612 & 67.92 & & & & & & & \\
\hline $\begin{array}{l}\text { San Andrés } \\
\text { Larrainzar } \\
\text { (Tsotsil) }\end{array}$ & 22,375 & Very High & 18,935 & 84.63 & \begin{tabular}{|l|}
44.4 \\
\end{tabular} & \begin{tabular}{|l|}
54.9 \\
\end{tabular} & 34.2 & 26.0 & 16.8 & 34.6 & 11.5 \\
\hline $\begin{array}{c}\text { San Juan Cancuc } \\
\text { (Tseltal) }\end{array}$ & 31,732 & Very High & 28,501 & 89.82 & 25.2 & 35.9 & 15.0 & 62.4 & 40.2 & 84.5 & 11.1 \\
\hline $\begin{array}{l}\text { Tenejapa } \\
\text { (Tseltal) }\end{array}$ & 42,742 & Very High & 39,787 & 93.09 & 51.4 & 55.5 & 32.1 & 25.1 & 15.5 & 33.9 & 10.6 \\
\hline $\begin{array}{l}\text { Teopisca } \\
\text { (Mestizo) }\end{array}$ & 42,233 & High & 16,207 & 38.38 & 65.2 & \begin{tabular}{|l|}
73.2 \\
\end{tabular} & 57.2 & 30.2 & 23.4 & 36.5 & 11.5 \\
\hline Norte-Tulijá & 376,603 & High & 307,562 & 81.67 & & & & & & & \\
\hline $\begin{array}{l}\text { Tumbalá } \\
\text { (Ch'ol) }\end{array}$ & 34,414 & Very High & 30,850 & 89.64 & 59.0 & \begin{tabular}{|l|}
69.0 \\
\end{tabular} & 50.3 & 34.5 & 22.6 & 45.5 & 8.8 \\
\hline Los Llanos & 142,603 & High & 43,429 & 30.45 & & & & & & & \\
\hline $\begin{array}{l}\text { Venustiano } \\
\text { Carranza } \\
\text { (Mestizo) }\end{array}$ & 66,610 & High & 14,067 & 21.12 & \begin{tabular}{|l|}
94.0 \\
\end{tabular} & \begin{tabular}{|l|}
94.4 \\
\end{tabular} & 93.6 & 25.3 & 22.7 & 27.9 & 11.2 \\
\hline CHIAPAS & $5,317,960$ & $\begin{array}{l}48 \text { and } 43 \text { of } 118 \\
\text { municipalities are } \\
\text { classified as having } \\
\text { "Very High" and "High" } \\
\text { levels of social } \\
\text { marginalization, } \\
\text { respectively }\end{array}$ & $1,356,526$ & 25.51 & \begin{tabular}{|l|}
63.9 \\
\end{tabular} & \begin{tabular}{|l|}
71.4 \\
\end{tabular} & 56.5 & \begin{tabular}{|l|}
17.7 \\
\end{tabular} & \begin{tabular}{|l|}
13.4 \\
\end{tabular} & 21.8 & 9.4 \\
\hline MEXICO*** & $112,336,538$ & & $6,913,362$ & 6.5 & 80.4 & \begin{tabular}{|l|l|}
83.8 \\
\end{tabular} & 77.1 & 64.5 & 62.7 & 66.2 & 8.1 \\
\hline
\end{tabular}


Table 3. Education, 2010

\begin{tabular}{|c|c|c|c|c|c|c|c|c|c|c|c|c|c|c|c|c|}
\hline \multirow[t]{2}{*}{$\begin{array}{l}\text { Region, } \\
\text { municipality, } \\
\text { and ethnicity }\end{array}$} & \multicolumn{3}{|c|}{$\begin{array}{c}\text { Population } \\
\text { over age } 15 \text { illiterate } \\
\text { (percent) }\end{array}$} & \multicolumn{3}{|c|}{$\begin{array}{c}\text { Population } \\
\text { over age } 15 \\
\text { without any schooling } \\
\text { (percent) }\end{array}$} & \multicolumn{3}{|c|}{$\begin{array}{l}\text { Population over age } 15 \\
\text { with primary school } \\
\text { completed } \\
\text { (percent) }\end{array}$} & \multicolumn{3}{|c|}{$\begin{array}{l}\text { Population over age } 15 \\
\text { with high school } \\
\text { (percent) }\end{array}$} & \multicolumn{3}{|c|}{$\begin{array}{l}\text { Population over age } 15 \\
\text { with some college } \\
\text { (percent) }\end{array}$} & \multirow{2}{*}{$\begin{array}{c}\begin{array}{c}\text { Average } \\
\text { number of } \\
\text { school grades } \\
\text { completed }\end{array} \\
\text { All }\end{array}$} \\
\hline & All & Male & Female & All & Male & Female & All & Male & Female & All & Male & Female & All & Male & Female & \\
\hline \multicolumn{17}{|l|}{ Los Altos } \\
\hline $\begin{array}{c}\text { San Andrés } \\
\text { Larrainzar } \\
\text { (Tsotsil) }\end{array}$ & 26.0 & 16.8 & \begin{tabular}{|l}
34.6 \\
\end{tabular} & 22.4 & \begin{tabular}{|l|}
14.6 \\
\end{tabular} & 29.7 & 51.5 & \begin{tabular}{|l|}
52.1 \\
\end{tabular} & 51.0 & 1.2 & 1.6 & \begin{tabular}{|l|}
0.9 \\
\end{tabular} & 0.1 & \begin{tabular}{|l|}
1.4 \\
\end{tabular} & 0.6 & 4.9 \\
\hline $\begin{array}{l}\text { San Juan } \\
\text { Cancuc } \\
\text { (Tseltal) }\end{array}$ & 62.4 & 40.2 & 84.5 & 31.2 & 20.2 & 41.5 & \begin{tabular}{|l|}
46.2 \\
\end{tabular} & \begin{tabular}{|l|}
46.9 \\
\end{tabular} & 45.5 & 1.3 & 2.1 & \begin{tabular}{|l|}
0.6 \\
\end{tabular} & 1.0 & \begin{tabular}{|l|}
0.2 \\
\end{tabular} & 0.6 & 4.2 \\
\hline $\begin{array}{l}\text { Tenejapa } \\
\text { (Tseltal) }\end{array}$ & 25.1 & 15.5 & 33.9 & \begin{tabular}{|l|}
19.7 \\
\end{tabular} & 11.6 & 27.1 & \begin{tabular}{|l|}
57.7 \\
\end{tabular} & 58.7 & 56.7 & 0.9 & 1.3 & 0.5 & 0.5 & \begin{tabular}{|l|}
0.8 \\
\end{tabular} & 0.2 & 4.9 \\
\hline $\begin{array}{l}\text { Teopisca } \\
\text { (Mestizo) }\end{array}$ & 30.2 & 23.4 & 36.5 & 29.1 & 23.5 & 34.2 & \begin{tabular}{|l|}
48.9 \\
\end{tabular} & 51.3 & 46.8 & 0.8 & 1.0 & \begin{tabular}{|l}
0.7 \\
\end{tabular} & 2.9 & 3.8 & 2.1 & \begin{tabular}{|l}
4.4 \\
\end{tabular} \\
\hline \multicolumn{17}{|l|}{ Norte-Tulijá } \\
\hline $\begin{array}{r}\text { Tumbalá } \\
\text { (Ch'ol) }\end{array}$ & 34.5 & 22.6 & 45.5 & 28.5 & \begin{tabular}{|l|}
17.5 \\
\end{tabular} & 38.7 & 35.6 & 38.7 & 32.7 & 2.2 & 2.6 & 1.8 & 1.8 & \begin{tabular}{|l|}
2.7 \\
\end{tabular} & 1.1 & \begin{tabular}{|l|}
4.9 \\
\end{tabular} \\
\hline \multicolumn{17}{|l|}{ Los Llanos } \\
\hline $\begin{array}{l}\text { Venustiano } \\
\text { Carranza } \\
\text { (Mestizo) }\end{array}$ & 25.3 & 22.7 & 27.9 & 24.9 & 23.1 & 26.6 & 38.5 & 37.8 & 39.2 & 1.7 & 1.9 & 1.6 & 4.9 & \begin{tabular}{|l}
6.0 \\
\end{tabular} & 3.8 & 5.4 \\
\hline CHIAPAS & 17.7 & \begin{tabular}{|l|}
13.4 \\
\end{tabular} & 21.8 & \begin{tabular}{|l|}
16.4 \\
\end{tabular} & 12.9 & 19.7 & 38.0 & 38.0 & 37.9 & 2.2 & 2.4 & 1.9 & 9.7 & 10.8 & 8.8 & 6.6 \\
\hline MEXICO & 6.8 & 5.5 & 8.0 & \begin{tabular}{|l|}
6.8 \\
\end{tabular} & 5.8 & 7.8 & \begin{tabular}{|l|}
28.7 \\
\end{tabular} & 27.1 & 29.3 & 2.8 & 3.1 & 2.6 & 16.5 & \begin{tabular}{|l|}
17.1 \\
\end{tabular} & 15.9 & 8.6 \\
\hline
\end{tabular}

Source: Author's elaboration based on INEGI. Censo de Poblacion y Vivienda 2010.

Table 4. Housing Conditions, 2010

\begin{tabular}{|c|c|c|c|c|c|c|c|c|c|c|c|c|}
\hline \multirow{2}{*}{$\begin{array}{c}\text { Region, } \\
\text { municipality, } \\
\text { and ethnicity }\end{array}$} & \multirow{2}{*}{$\begin{array}{c}\text { Total } \\
\text { number of } \\
\text { inhabited } \\
\text { dwelling }\end{array}$} & \multicolumn{11}{|c|}{ Dwelling Services, Conditions, and Electronics (percent) } \\
\hline & & $\begin{array}{l}\text { Non-dirt } \\
\text { floors }\end{array}$ & $\begin{array}{c}\text { Concrete } \\
\text { roofs }\end{array}$ & $\begin{array}{l}\text { Piped } \\
\text { water }\end{array}$ & $\begin{array}{c}\text { Piped } \\
\text { sewage }\end{array}$ & Electricity & $\begin{array}{l}\text { Cooking } \\
\text { with gas }\end{array}$ & $\begin{array}{l}\text { Cooking } \\
\text { with } \\
\text { firewood }\end{array}$ & $\begin{array}{c}\text { Firewood } \\
\text { saving } \\
\text { stoves }\end{array}$ & Refrigerator & TV & Radio \\
\hline \multicolumn{13}{|l|}{ Los Altos } \\
\hline $\begin{array}{c}\text { San Andrés } \\
\text { Larrainzar } \\
\text { (Tsotsil) }\end{array}$ & 3,909 & 80.5 & 7.5 & 9.7 & 11.5 & 93.6 & 4.3 & 95.2 & 30.1 & 2.8 & 20.8 & 31.3 \\
\hline $\begin{array}{l}\text { San Juan } \\
\text { Cancuc } \\
\text { (Tseltal) }\end{array}$ & 5,121 & 59.1 & 7.9 & 6.3 & 3.4 & 93.2 & 0.5 & 99.3 & 2.5 & 1.1 & 25.0 & 37.7 \\
\hline $\begin{array}{l}\text { Tenejapa } \\
\text { (Tseltal) }\end{array}$ & 7,177 & 77.0 & 13.1 & 15.3 & 7.9 & 96.0 & 2.9 & 96.8 & 18.8 & 2.3 & 30.7 & 45.3 \\
\hline $\begin{array}{l}\text { Teopisca } \\
\text { (Mestizo) }\end{array}$ & 7,939 & 80.5 & 26.7 & 49.7 & 64.6 & 95.7 & 26.0 & 72.7 & 33.8 & 26.1 & 64.4 & 66.7 \\
\hline \multicolumn{13}{|l|}{ Norte-Tulijá } \\
\hline $\begin{array}{c}\text { Tumbalá } \\
\text { (Ch’ol) }\end{array}$ & 6,168 & 76.5 & 7.5 & 11.7 & 28.5 & 89.0 & 4.9 & 94.4 & 14.7 & 15.8 & 45.3 & 54.1 \\
\hline \multicolumn{13}{|l|}{ Los Llanos } \\
\hline $\begin{array}{l}\text { Venustiano } \\
\text { Carranza } \\
\text { (Mestizo) }\end{array}$ & 14,695 & 88.0 & 20.8 & 39.8 & 72.2 & 97.1 & 42.1 & 57.3 & 12.4 & 58.1 & 84.2 & 68.5 \\
\hline CHIAPAS & $1,091,100$ & 84.8 & 29.7 & 33.6 & 51.4 & 95.8 & 48.6 & 51.4 & 29.0 & 57.9 & 76.6 & 66.0 \\
\hline MEXICO & $28,138,556$ & 93.1 & 71.6 & 90.1 & 70.5 & 97.7 & 83.8 & 14.4 & & 82.0 & 92.5 & 79.5 \\
\hline
\end{tabular}

Source: Author's elaboration based on INEGI. Censo de Poblacion y Vivienda 2010. 
Table 5. Ejidos and Communities, Ejidatarios and Comuneros by Gender

\begin{tabular}{|c|c|c|c|c|c|c|c|c|c|c|c|c|}
\hline \multirow{2}{*}{$\begin{array}{c}\text { Region, } \\
\text { Municipality, } \\
\text { and Ethnicity }\end{array}$} & \multirow[t]{2}{*}{$\begin{array}{c}\text { Number of } \\
\text { ejidos and } \\
\text { communities }\end{array}$} & \multicolumn{3}{|c|}{$\begin{array}{l}\text { Ejidatarios and comuneros } \\
\text { (total and percent) }\end{array}$} & \multicolumn{4}{|c|}{$\begin{array}{l}\text { Ejidatarios and comuneros } \\
\text { with Individual Parcels } \\
\text { (total and percent) }\end{array}$} & \multicolumn{4}{|c|}{$\begin{array}{c}\text { Ejidatarios and comuneros with collective } \\
\text { parcels } \\
\text { (total and percent) }\end{array}$} \\
\hline & & Total & Men & Women & Total & Percent & Men & Women & Total & Percent & Men & Women \\
\hline \multicolumn{13}{|l|}{ Los Altos } \\
\hline $\begin{array}{l}\text { San Andrés } \\
\text { Larrainzar } \\
\text { (Tsotsil) }\end{array}$ & 3 & 1,912 & 97.3 & 2.6 & 41 & 2.1 & 2.0 & 0.05 & 1,871 & 97.8 & 95.2 & 2.6 \\
\hline $\begin{array}{l}\text { San Juan } \\
\text { Cancuc } \\
\text { (Tseltal) }\end{array}$ & 1 & 6,500 & 99.8 & 0.01 & 6,500 & 100.0 & 99.8 & 0.01 & 0.0 & 0.0 & 0.0 & 0.0 \\
\hline $\begin{array}{l}\text { Tenejapa } \\
\text { (Tseltal) }\end{array}$ & 7 & 3,850 & 83.3 & 13.4 & 3,792 & 98.4 & 85.0 & 13.4 & 58 & 1.5 & 1.4 & 0.02 \\
\hline $\begin{array}{l}\text { Teopisca } \\
\text { (Mestizo) }\end{array}$ & 16 & 1,936 & 95.8 & 4.1 & 1,936 & 100.0 & 95.8 & 4.1 & 0.00 & 0.00 & 0.00 & 0.00 \\
\hline \multicolumn{13}{|l|}{ Norte-Tulijá } \\
\hline $\begin{array}{c}\text { Tumbalá } \\
\text { (Ch'ol) }\end{array}$ & 24 & 2,812 & 95.9 & 4.1 & 2,329 & 82.8 & 79.9 & 2.8 & 483 & 17.1 & 16.3 & 1.1 \\
\hline \multicolumn{13}{|l|}{ Los Llanos } \\
\hline $\begin{array}{l}\text { Venustiano } \\
\text { Carranza } \\
\text { (Mestizo) }\end{array}$ & 41 & 21,053 & 68.4 & 31.5 & 10,090 & 47.9 & 41.1 & 6.7 & 10,963 & 52.0 & 27.2 & 24.8 \\
\hline CHIAPAS & 2,823 & \begin{tabular}{|l|}
351,933 \\
\end{tabular} & 86.44 & 13.55 & 269,950 & 76.7 & 87.6 & 12.3 & 81,983 & 23.2 & 19.1 & 4.1 \\
\hline MEXICO & 31,514 & $4,210,830$ & 80.19 & 19.8 & $3,392,126$ & 80.5 & 81.9 & 18.0 & 818,704 & 19.4 & 14.1 & 5.2 \\
\hline
\end{tabular}

Source: own elaboration based on INEGI. Censo Ejidal 2007.

Table 6. Employment and Income (percent), 2010

\begin{tabular}{|c|c|c|c|c|c|c|c|c|}
\hline \multirow{2}{*}{$\begin{array}{l}\text { Region, } \\
\text { Municipality, } \\
\text { and Ethnicity }\end{array}$} & \multicolumn{3}{|c|}{ Population employed } & \multirow{2}{*}{$\begin{array}{c}\text { Workers } \\
\text { employed in } \\
\text { primary sector }\end{array}$} & \multirow{2}{*}{$\begin{array}{c}\text { Workers } \\
\text { employed in } \\
\text { secondary } \\
\text { sector }\end{array}$} & \multirow[t]{2}{*}{ Commerce } & \multirow{2}{*}{$\begin{array}{l}\text { Workers } \\
\text { employed in } \\
\text { tertiary sector }\end{array}$} & \multirow{2}{*}{$\begin{array}{c}\text { Income: } \\
\text { one or less } \\
\text { minimum } \\
\text { monthly salary } \\
\text { (percent) }\end{array}$} \\
\hline & All & Male & Female & & & & & \\
\hline \multicolumn{9}{|l|}{ Los Altos } \\
\hline $\begin{array}{l}\text { San Andrés } \\
\text { Larrainzar } \\
\text { (Tsotsil) }\end{array}$ & 43.9 & 73.2 & 16.1 & 75.4 & 16.6 & 2.0 & 4.9 & 89.3 \\
\hline $\begin{array}{l}\text { San Juan } \\
\text { Cancuc } \\
\text { (Tseltal) }\end{array}$ & 39.4 & 71.1 & 9.6 & 96.4 & 1.3 & 0.6 & 1.5 & 95.3 \\
\hline $\begin{array}{l}\text { Tenejapa } \\
\text { (Tseltal) }\end{array}$ & 44.5 & 75.4 & 15.6 & 88.0 & 3.9 & 2.1 & 5.1 & 90.8 \\
\hline $\begin{array}{l}\text { Teopisca } \\
\text { (Mestizo) }\end{array}$ & 46.2 & 79.3 & 15.9 & 44.7 & 24.4 & 13.4 & 16.8 & 57.7 \\
\hline \multicolumn{9}{|l|}{ Norte-Tulijá } \\
\hline $\begin{array}{c}\text { Tumbalá } \\
\text { (Ch'ol) }\end{array}$ & 37.6 & 72.3 & 4.9 & 86.0 & 2.2 & 2.6 & 8.3 & 87.3 \\
\hline \multicolumn{9}{|l|}{ Los Llanos } \\
\hline $\begin{array}{l}\text { Venustiano } \\
\text { Carranza } \\
\text { (Mestizo) }\end{array}$ & 49.4 & 77.1 & 21.8 & 54.7 & 15.2 & 9,9 & 19.5 & 62.0 \\
\hline CHIAPAS & 46.9 & 74.1 & 21.3 & 42.7 & 13.5 & 13.8 & 29.0 & 45.7 \\
\hline MEXICO & 38.0 & 65.1 & 34.8 & 13.3 & 24.4 & 19.2 & 41.6 & 8.8 \\
\hline
\end{tabular}

Source: own elaboration based on INEGI. Censo de Poblacion y Vivienda 2010.

$\sim$ Includes employees who do not receive a salary 


\section{New Geographies: Zapatista Autonomy and Low Intensity-War \\ The Setting in Context}

During my fieldwork I gathered data from 56 communities located in the areas of Los Altos, Norte-Tulijá, and Los Llanos (see Figure 2C and Table 1; and the Research Methods). This group of communities is large enough to represent both the heterogeneity and the similarities that exist among peasant communities in Chiapas-indigenous and mestizo, Zapatistas and non-Zapatistas. Examining these differences is useful for analyzing how communities perceive the ideas of food and seed sovereignty in a context in which the dispute over territory and natural resources is constantly redefining how, by whom, and for what purposes land and resources are used.

There are several important differences among the communities analyzed in this study (see Table 7). The first is whether or not communities participate in DESMI's Guardians of Mother Earth and Seeds project. Almost half of the communities in this study ( 25 total) are part of the project. The rest (31 communities) are not participants but they are involved, to different degrees, with this agenda of food and seed sovereignty.

Ethnicity and land tenure are two other variables that reflect the heterogeneity that exists in the area of research. The large majority of the 56 study communities are indigenous communities (53) from the ethnic groups Tsotsil (25), Tseltal (16), and Ch'ol (12). There are only three mestizo communities in the study, from the municipalities of Venustiano Carranza and Teopisca, where mestizo communities predominate (see Table 7).

Regarding land tenure (Figure 3), 41 of the study communities are formally 
indigenous or agrarian communities (comunidades agrarias). This refers to communities that have federal recognition of the preexisting land claims of indigenous people, many of whom hold titles granted by the Spanish crown ${ }^{2}$ (see Wolf 1956: 1067). Another 13 communities are ejidos, a grant of land by the state to a group of families, most of them mestizo people —although in this case, the $12 \mathrm{Ch}$ 'ol indigenous communities are also ejidos. One non-Zapatista mestizo ejido is involved in land conflicts, and paramilitary groups have partially displaced its inhabitants. Finally, one non-Zapatista mestizo community has occupied land from a finca and it does not have property title. I will expand upon this information in the following chapters.

Table 7. Community Characteristics

\begin{tabular}{|c|c|c|c|c|c|c|}
\hline \multirow{2}{*}{$\begin{array}{l}\text { Region and } \\
\text { municipality }\end{array}$} & \multirow[b]{2}{*}{$\begin{array}{c}\text { Predominant } \\
\text { ethnicity, and } \\
\text { percentage of } \\
\text { indigenous people } \\
\text { in the } \\
\text { municipality* }\end{array}$} & \multicolumn{5}{|c|}{ Number and characteristics of communities participating in this study } \\
\hline & & $\begin{array}{l}\text { Number/ } \\
\text { ethnicity }\end{array}$ & Land tenure & $\begin{array}{l}\text { Average land } \\
\text { per family } \\
\text { (hectares) }\end{array}$ & $\begin{array}{c}\text { Members of } \\
\text { Guardians of } \\
\text { Mother Earth and } \\
\text { Seeds Project }\end{array}$ & $\begin{array}{c}\text { Presence of Zapatista } \\
\text { bases in the } \\
\text { municipality/ } \\
\text { corresponding Junta de } \\
\text { Buen Gobierno (JBG) }\end{array}$ \\
\hline Los Altos & $\begin{array}{c}\text { Tsotsil and Tseltal } \\
67.9 \\
\end{array}$ & & & & & \\
\hline $\begin{array}{l}\text { San Andrés } \\
\text { Larrainzar }\end{array}$ & $\begin{array}{c}\text { Tsotsil } \\
84.6 \\
\end{array}$ & $\begin{array}{c}25 \\
\text { Tsotsil } \\
\end{array}$ & $\begin{array}{l}\text { Indigenous } \\
\text { community }\end{array}$ & 2.1 & No & $\begin{array}{l}\text { Very strong } \\
\text { JBG Oventic }\end{array}$ \\
\hline $\begin{array}{c}\text { San Juan } \\
\text { Cancuc }\end{array}$ & $\begin{array}{c}\text { Tseltal } \\
89.8 \\
\end{array}$ & $\begin{array}{c}10 \\
\text { Tseltal } \\
\end{array}$ & $\begin{array}{l}\text { Indigenous } \\
\text { community }\end{array}$ & 1.8 & Yes & $\begin{array}{l}\text { Very strong } \\
\text { JBG Oventic }\end{array}$ \\
\hline Tenejapa & $\begin{array}{c}\text { Tseltal } \\
93.0 \\
\end{array}$ & $\begin{array}{c}6 \\
\text { Tseltal } \\
\end{array}$ & $\begin{array}{l}\text { Indigenous } \\
\text { community }\end{array}$ & 2.8 & No & $\begin{array}{l}\text { Very strong } \\
\text { JBG Oventic }\end{array}$ \\
\hline Teopisca & $\begin{array}{c}\text { Mestizo } \\
38.3\end{array}$ & $\begin{array}{c}2 \\
\text { Mestizo }\end{array}$ & $\begin{array}{c}\text { One ejido; } \\
\text { one community } \\
\text { on occupied land }\end{array}$ & 2.7 & Yes & $\begin{array}{c}\text { Low } \\
\text { JBG Morelia }\end{array}$ \\
\hline Norte Tulijá & $\begin{array}{l}\text { Ch'ol } \\
81.6 \\
\end{array}$ & & & & & \\
\hline Tumbalá & $\begin{array}{l}\text { Ch'ol } \\
89.6 \\
\end{array}$ & $\begin{array}{c}12 \\
\text { Ch'ol } \\
\end{array}$ & Ejidos & 2.5 & Yes & $\begin{array}{c}\text { Very strong } \\
\text { JBG Roberto Barrios }\end{array}$ \\
\hline Los Llanos & $\begin{array}{c}\text { Mestizo } \\
30.4\end{array}$ & & & & & \\
\hline $\begin{array}{l}\text { Venustiano } \\
\text { Carranza }\end{array}$ & $\begin{array}{c}\text { Mestizo } \\
21.1\end{array}$ & $\begin{array}{c}1 \\
\text { Mestizo }\end{array}$ & $\begin{array}{l}\text { Ejido partially } \\
\text { displaced by } \\
\text { paramilitary } \\
\text { groups } \\
\end{array}$ & 3.4 & Yes & $\begin{array}{l}\text { Very strong } \\
\text { JBG Oventic }\end{array}$ \\
\hline Total & & 56 & & 2.5 & 25 & \\
\hline
\end{tabular}




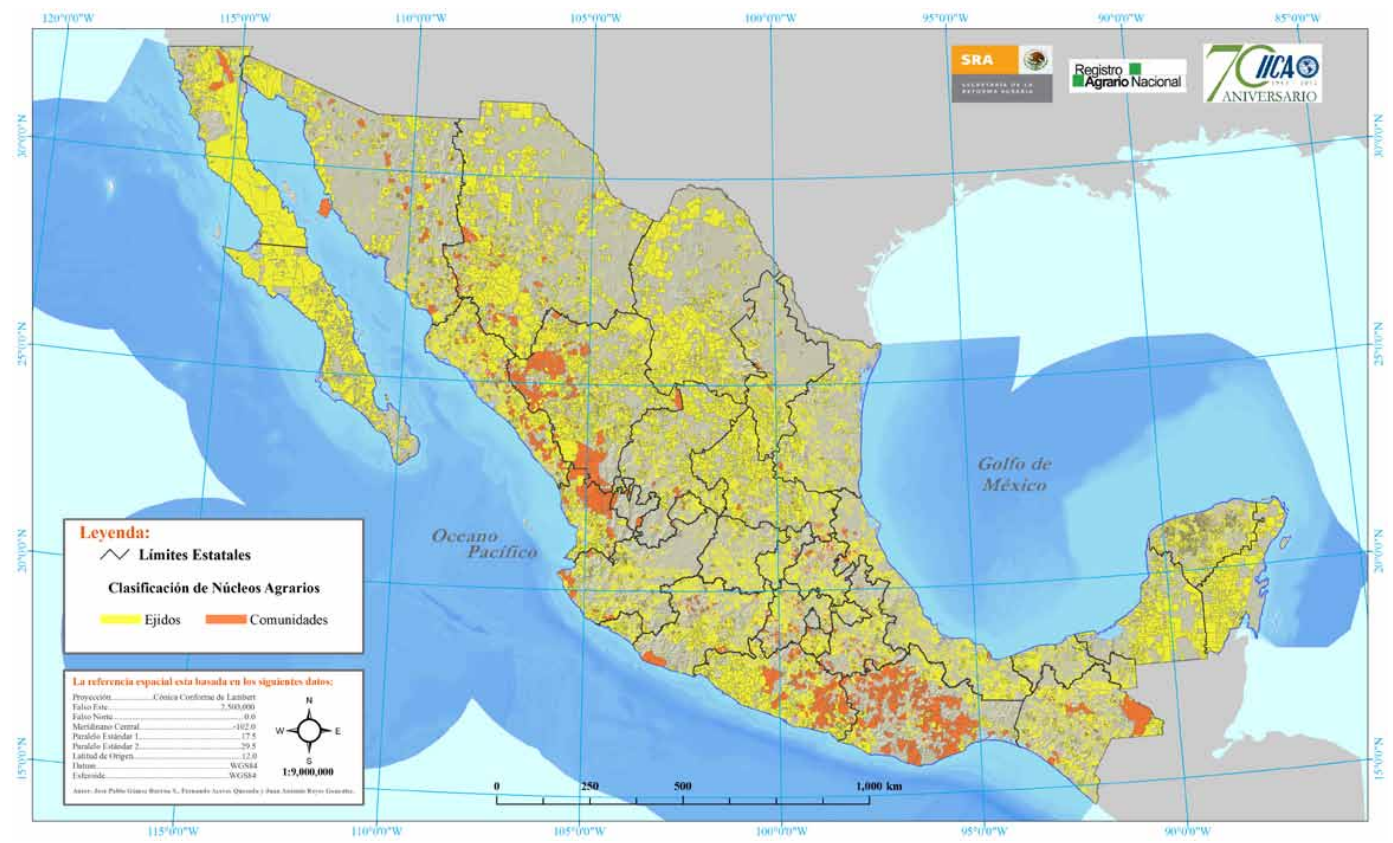

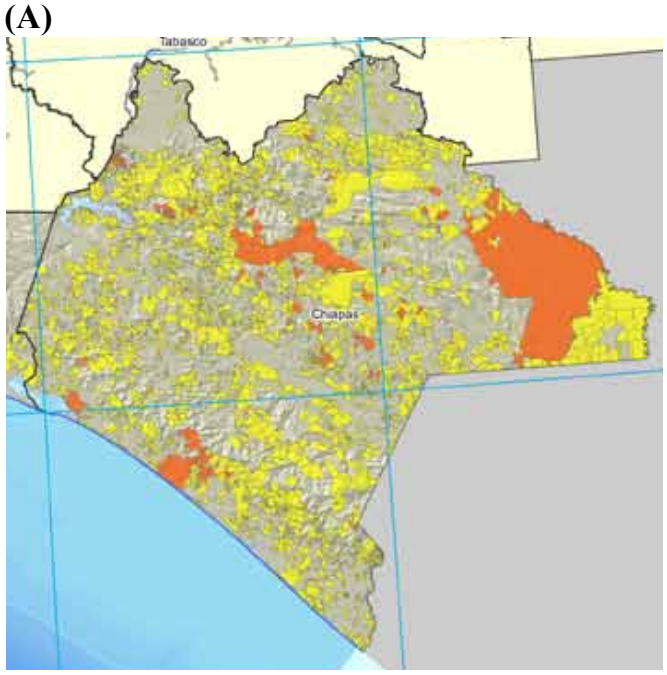

(B)

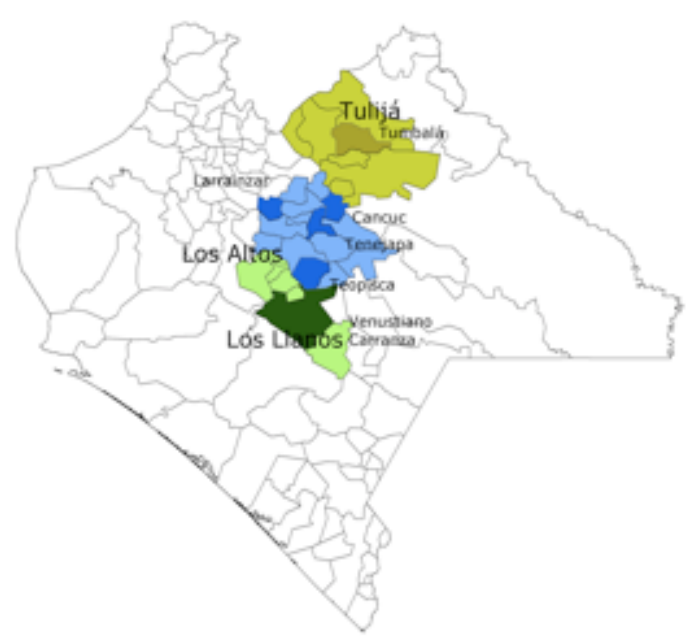

(C)

Figure 3. (A) Communal Land Tenure in Mexico: Ejidos (in yellow) and Comunidades Agrarias or indigenous communities (in orange), 2012 (reprinted from IICA, 2012); (B) Ejidos and Comunidades Agrarias in Chiapas, 2012 (reprinted from IICA, 2012); (C) Area of Research, by Regions and Municipalities (author's elaboration). 
Another important difference among the 56 communities is their degree of affiliation with the EZLN. Considering that the most important social movement in Chiapas is the EZLN, the main distinction I will make here is between Zapatista and nonZapatista communities, which I discuss in greater detail below. However, the region is a mosaic of social movements and political initiatives in which both Zapatistas and nonZapatistas coincide and collaborate. The most relevant of these are the Pastoral of Mother Earth, the Indian Theology, and the Faithful People, which are all related, in different degrees, to the dioceses of San Cristóbal de las Casas and liberation theology. ${ }^{3}$ Indeed, the Guardians of Mother Earth and Seeds project brings together essential elements of all these social actors and political agendas.

Regarding the non-Zapatista communities in this study, they can be categorized on a gradient according to their relationship with the EZLN. DESMI does not work with communities that are hostile to the EZLN or have a strong presence of paramilitary groups. The relationship between Zapatista and non-Zapatista communities is essentially framed in the EZLN's Sixth Declaration of the Selva Lacandona — or The Other Campaign, La Otra Campana (June 2005) — in which the Zapatista movement called for "the creation of political alliances among communities, collectives, organizations, and individuals in resistance, and against neoliberalism and for humanity." The movement also offered its support—logistic, material, and informational — to those who were interested in joining its efforts "to build FROM BELOW AND FOR BELOW an alternative to neoliberal destruction" (capitals in original) (EZLN 2005a). A central objective of this convocation was to coordinate a national campaign against the neoliberal 
agenda for the privatization of electricity, oil, water, and other natural resources (EZLN 2005b). Communities and individuals who have endorsed this campaign often define themselves as "adherentes a la Otra Campaña" or "adherents to The Other Campaign."

Within this framework, the non-Zapatista communities in this study can be classified into three groups. The first are communities in resistance that are involved in land conflicts and openly identify themselves as adherents to The Other Campaign. Two of the three mestizo communities in this study can be classified in this category. A second group is composed of communities with a relatively strong relationship with the movement, where inhabitants use some of the services offered by Zapatista communities — such as hospitals and justice institutions - and/or participate in seminars and informational meetings organized by the EZLN for analyzing political and economic events affecting all communities in the area. The large majority of non-Zapatista communities in this study belong to this subgroup, and all of them are indigenous. A third classification is made only for a single mestizo community whose families left the EZLN years ago but continue to participate in other spaces and initiatives focused on fair trade, organic production, and women empowerment. DESMI continues to work with these families because most of them have women as heads of household and they are organized in cooperatives of production focused on food security and agroecology. Regardless of their affiliation to the EZLN, all of the communities in this study are located in the area of conflict (Figure 5). The following section focuses on the Zapatista movement and the construction of its autonomous government. 


\section{Resistance, Autonomy, and Counter-Insurgency}

Zapatista communities are autonomous entities ruled by the EZLN's structures of government—Good Government Councils or Juntas de Buen Gobierno, JBGs. These JBGs are organized into five territorial areas or Caracoles_- "snails," an image representing the idea of horizontal and circular ways of decision-making ${ }^{4}$ (EZLN 2014d). Zaga estimates that about 1,000 communities, encompassing 750,000 Zapatistas, are presently integrated into 27 autonomous municipalities (Municipios Autónomos Rebeldes Zapatistas, or MAREZ). These autonomous municipalities overlap, in whole or in part, with 38 of the 118 official municipalities of Chiapas (see Table 8, and Figures 4, and 5B, 5C, 5D) (Zaga 2015: 15). The MAREZ are delimited territories that are under the control of the EZLN, but their borders might change in response to expansions or reductions of autonomous communities or fluctuations in the number of Zapatista supporters in each community (Klein 2015: xvii).

Table 8. Zapatista Government Structure Since 2003:

Caracoles, Juntas de Buen Gobierno, Autonomous Municipalities, and Ethnic Groups

\begin{tabular}{|c|c|c|c|}
\hline Caracoles & $\begin{array}{l}\text { Juntas de Buen } \\
\text { Gobierno (JBG) }\end{array}$ & $\begin{array}{c}\text { Autonomous Municipalities } \\
\text { (MAREZ) } \\
\text { (Comprise approx. one-third of the } \\
\text { territory of Chiapas*) }\end{array}$ & Ethnicity \\
\hline $\begin{array}{l}\text { I. Caracol La Realidad } \\
\text { "Madre de los } \\
\text { Caracoles del Mar de } \\
\text { Nuestros Sueños" }\end{array}$ & "Hacia La Esperanza" & $\begin{array}{l}\text { 1. General Emiliano Zapata } \\
\text { 2. San Pedro de Michoacán } \\
\text { 3. Libertad de los Pueblos Mayas } \\
\text { 4. Tierra y Libertad }\end{array}$ & $\begin{array}{l}\text { Tojolabal, } \\
\text { Tseltal, and } \\
\text { Mam }\end{array}$ \\
\hline $\begin{array}{l}\text { II. Caracol de Morelia } \\
\text { "Torbellino de } \\
\text { Nuestras Palabras" }\end{array}$ & $\begin{array}{l}\text { "Corazón del Arcoiris } \\
\text { de la Esperanza" }\end{array}$ & $\begin{array}{l}\text { 5. } 17 \text { de Noviembre } \\
\text { 6. Primero de Enero } \\
\text { 7. Ernesto Ché Guevara } \\
\text { 8. Olga Isabel } \\
\text { 9. Lucio Caballas } \\
\text { 10. Miguel Hidalgo } \\
\text { 11. Vicente Guerrero }\end{array}$ & $\begin{array}{l}\text { Tseltal, } \\
\text { Tsotsil, } \\
\text { Tojolabal }\end{array}$ \\
\hline
\end{tabular}




\begin{tabular}{|c|c|c|c|}
\hline $\begin{array}{l}\text { III. Caracol de La } \\
\text { Garrucha } \\
\text { "Resistencia Hacia un } \\
\text { Nuevo Amanecer" }\end{array}$ & $\begin{array}{l}\text { "El Camino del } \\
\text { Futuro" }\end{array}$ & $\begin{array}{l}\text { 12. Francisco Gómez } \\
\text { 13. San Manuel } \\
\text { 14. Francisco Villa } \\
\text { 15. Ricardo Flores Magón }\end{array}$ & Tseltal \\
\hline $\begin{array}{l}\text { IV. Caracol de Roberto } \\
\text { Barrios } \\
\text { "El Caracol que Habla } \\
\text { para Todos" }\end{array}$ & $\begin{array}{l}\text { "Nueva Semilla que } \\
\text { va a Producir" }\end{array}$ & $\begin{array}{l}\text { 16. Vicente Guerrero } \\
\text { 17. Del Trabajo } \\
\text { 18. La Montaña } \\
\text { 19. San José en Rebeldía } \\
\text { 20. La Paz } \\
\text { 21. Benito Juarez } \\
\text { 22. Francisco Villa }\end{array}$ & $\begin{array}{l}\text { Ch'ol } \\
\text { Zoque } \\
\text { Tseltal }\end{array}$ \\
\hline $\begin{array}{l}\text { V. Caracol de Oventik } \\
\text { "Resistencia y } \\
\text { Rebeldía por la } \\
\text { Humanidaad" }\end{array}$ & $\begin{array}{l}\text { "Corazón Céntrico de } \\
\text { los Zapatistas Delante } \\
\text { del Mundo" }\end{array}$ & $\begin{array}{l}\text { 23. San Andrés Sakamchén de los } \\
\text { Pobres } \\
\text { 24. San Juan de la Libertad } \\
\text { 25. San Pedro Polhó } \\
\text { 26. Magdalena de la Paz } \\
\text { 27. } 16 \text { de Febrero }\end{array}$ & $\begin{array}{l}\text { Tsotsil } \\
\text { Tseltal }\end{array}$ \\
\hline
\end{tabular}

Source: Author's elaboration based on CEDOZ,(CEDOZ 2018a) ; * Castellanos 2014.

Figure 4. Political Organization of the Zapatistas Since 2003

\begin{tabular}{|c|c|c|}
\hline State Level & 5 Caracoles & $\begin{array}{l}\text { Good Government Council (Juntas de Buen } \\
\text { Gobierno), justice institutions, schools, health centers, } \\
\text { etc. }\end{array}$ \\
\hline Municipal Level & 27 MAREZ & $\begin{array}{l}\text { Autonomous Councils (Municipios Autónomos); } \\
1 \text { or } 2 \text { representatives from each MAREZ per Caracol }\end{array}$ \\
\hline Local Level & $>1,000$ communities & 1 representative from each community per MAREZ \\
\hline Individual Level & 750,000 individuals & $\begin{array}{l}\text { - Civilian Support Base (most of community members) } \\
\text { - Militias (temporary military support to insurgents in } \\
\text { time of crisis; active members in their communities) } \\
\text { - Insurgents (full-time guerrillas living in camps outside } \\
\text { of their communities) }\end{array}$ \\
\hline
\end{tabular}

Source: Author's elaboration based on Zaga (2015: 15) and Barmeyer (2009: 78).

Nevertheless, Zapatista control over territory is not absolute. The Mexican army and paramilitary groups - armed groups that closely work with the military, trafficking 
cartels, and/or guardias blancas, private police groups financed by plantation ownershave a strong presence throughout the region, and the dynamics of what many observers call the low-intensity war (LIW) deeply impact the everyday lives of the Zapatista communities (see Figures 5E, 5F) (Aubry 1998).

The LIW's period of highest intensity was between 1994 and 1998—during the failed negotiation process of the Peace Agreements between the federal government and the EZLN. In 1998 it was estimated that a third of the Mexican military, approximately seventy thousand soldiers, was stationed in Chiapas. However, autonomous communities presently continue to face direct military and paramilitary hostilities through road closures, crop damage, eviction of communities, military seizure of schools and hospitals, killings, tortures, rapes, looting, and other human rights violations (Cortés 2009, Klein 2015: 112, Wild 1998, Zaga 2015: 10). According to the U.N., in 2011 there were 25,671 internally displaced people (5,320 families) in Chiapas as a consequence of the LIW. Although that figure is still very high, it has decreased substantially from the period between 1994 and 1998, when the number of displaced people reached between 50,000 and 90,000 (UN 2012: 23, 65). 

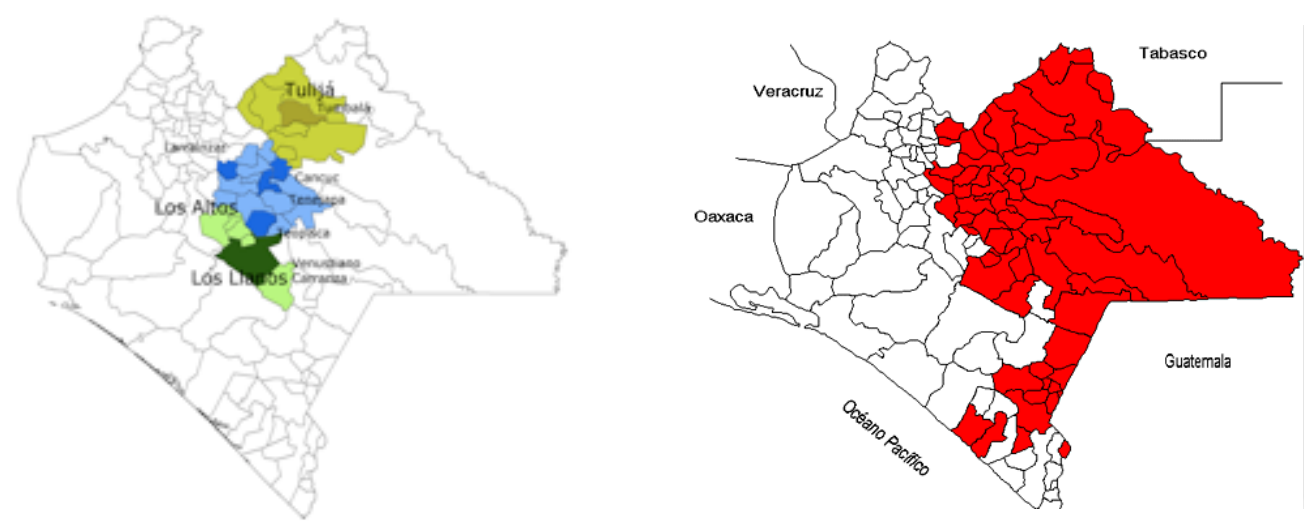

(A)

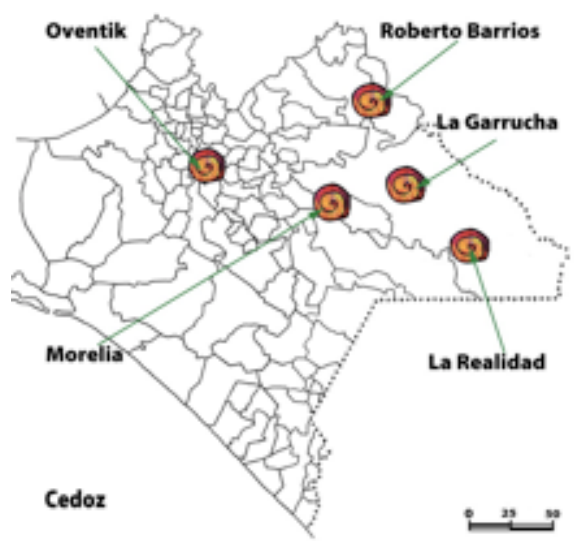

(B)

(C)

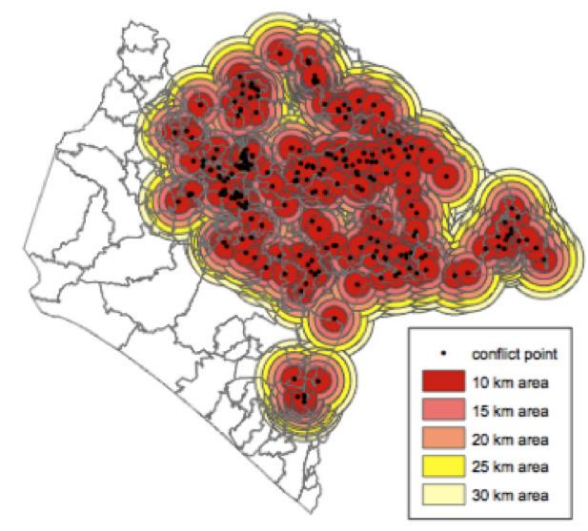

(E)

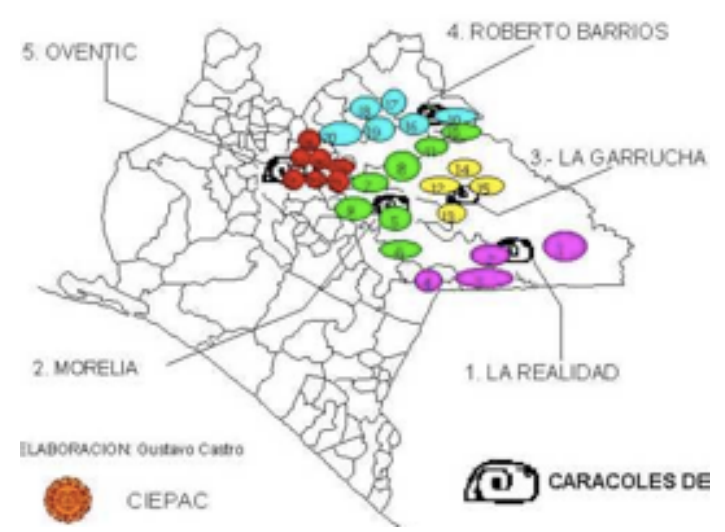

(D)

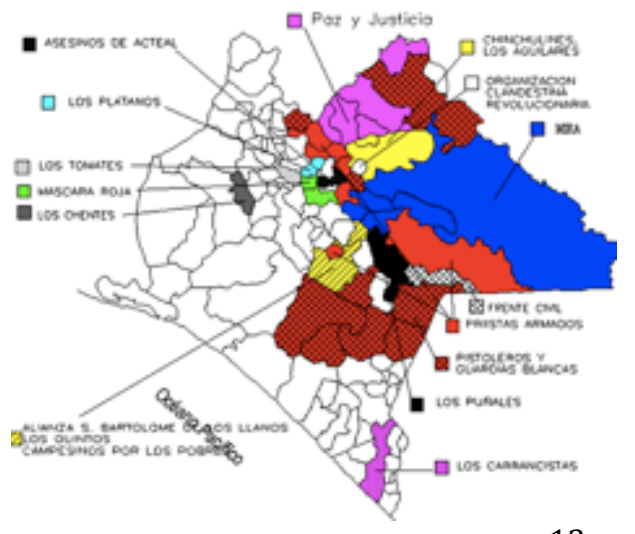

(F)

Figure 5. (A) Area of Research, by Regions and Municipalities (author's elaboration);

(B) Municipalities with the Presence of Zapatista Communities and their Influence Areas (2015) (reprinted from Zaga 2015); (C) Zapatista Caracoles (reprinted from CEDOZ 2017) (D) Autonomous Municipalities Corresponding to each Caracol (reprinted from CIEPAC 2018); (E) Police and Military Positions and their Influence Areas (1994-2000) (reprinted from Zaga 2015); (F) Paramilitary Groups (1998) (reprinted from CIEPAC 2018). 
At the individual level, there are three distinct forms in which Zapatistas can participate in the EZLN (see Figure 4), which depends on their age, gender, and the strength of their affiliation with the guerrilla organization: bases de apoyo (support base), milicianos (militias), and insurgentes (insurgents) (Barmeyer 2009: 78). According to Barmeyer, most community members constitute the civilian support base of the EZLN guerrilla army and are not part of the actual fighting unit. Their activities range from political demonstrations to logistical work and material support for the militias and insurgents (e.g., food and equipment). Militias and insurgents, on the other hand, are the armed branch of the EZLN. Militias are active members in their communities (they participate in collective activities, work a plot of land, and contribute to the community's economy) and are mobilized only in time of crisis. While staying in their communities, militias remain unarmed and do not perform any military, police, or justice functions. Becoming a member of the militias is an important opportunity that young people have for attaining social status in their communities (Barmeyer 2009: 78-79).

Insurgents, in contrast, are permanent guerrillas who live in camps in the mountains in inaccessible areas away from communities. Insurgents do not live with their families and do not participate in the everyday life of communities. Barmeyer notes that the guerrilla struggles are perceived by communities as a contribution to the long-term improvement of the social and economic situation in the villages. "However," writes Barmeyer, "they are missing as helpers on the fields, as caretakers of their parents, and (in the case of the men) as potential husbands for the slight surplus of women in their villages. Thus, although everyday material support to the insurgent camps from the 
villages may be relatively small, their actual net cost to the communities is immense. Their maintenance can therefore be regarded as an investment that the Zapatista base makes into its future" (2009: 79).

\section{Women and the EZLN}

Although the large majority of militias and insurgents are male (only one third of insurgents are women), there is a considerable number of indigenous women in all of the important ranks of the EZLN, from comandantas (the highest rank) in the military and CCRI-CG (Clandestine Revolutionary Indigenous Committee General Command), to government positions at the community, municipality, and JBG levels. In fact, since its foundation in 1983, the EZLN has radically transformed indigenous women's access to political and military leadership positions (Barmeyer 2009: 97-101, Cortés 2009, Klein 2015).

A landmark in the history of Mexico was the enactment of the Zapatista Revolutionary Law on Women in 1994, which grants indigenous women civil and human rights. ${ }^{5}$ This does not imply that gender inequality has vanished in Zapatista communities - indeed, patriarchal dynamics remain very much alive, particularly at the community level. However, the influence of the EZLN has positively impacted the lives of women, most notably the youngest (EZLN 1994, 2014c, 2015, Forbis 2011, Klein 2015).

The experience of Juana, a Tseltal indigenous woman from Tenejapa in her late forties, reflects this long-term process of change. Juana's story was narrated to me by her brother, Javier. Because she is the oldest daughter in her family, her parents refused to 
send her to school. She was obligated to help her mother in the house and take care of her five siblings - a common practice in many indigenous communities. In contrast, Javier, the second child, was encouraged to attend school, including seminary studies outside of Chiapas. Juana and Javier's family was among those who joined the EZLN in the 1980s. Although gender dynamics did not change immediately, the movement has had a major impact on Juana's family in the long run. Juana first learned how to write and read as part of the EZLN's educational program. Then, she started to participate in different government positions within the movement, and now she is part of the JBG in the Caracol of Oventic (one of the highest ranks in the civilian branch of the EZLN). Today, all women and girls in Juana's family, except for her mother, know how to read and write, and many of them participate as promotoras (promoters and teachers) in different committees of the EZLN (two of them in the area of agroecology, two in education, and one in health). ${ }^{6}$

However, as Klein (2015) points out, even if the participation of women in the autonomous government institutions has grown stronger since the reorganization of the movement in 2003, women still face several limitations such as male hostility—and even physical violence, predominantly at the community level from partners or fathersagainst women doing "office work," traveling to other communities to attend regional meetings, running their own productive cooperatives, or just learning how to write, read, and do elementary mathematics (see also Barmeyer 2009: 97-101). The amount of housework that women and girls are still responsible for performing on a daily basis, from before dawn until after sunset, also restrains them from occupying political 
positions and participating more actively in the movement (Barmeyer 2009: 97-101, Klein 2015: 242-248).

The autonomous justice system is also affected by a disparity between male and female representatives (Klein 2015: 181-188). Although there is a growing number of women in all EZLN political positions, this varies greatly among regions. The following testimony from a collective interview by Klein in 2006 with women from the Zapatista municipality of Olga Isabel illustrates this succinctly: "If there are no women on the Honor or Justice Commission or on the council, we can't go to them with our problems or tell them our stories...there are certain things we can't tell the men, it's too difficult. Some men still don't take us seriously, or they ask us questions but only so they can talk badly about us afterward" (Klein 2015: 184).

Despite these structural limitations, the EZLN has been successful in giving national and international voice to the demands of indigenous women (Klein 2015). It has been a consistent practice of the movement that important public speeches delivered by the EZLN at national fora are made by its comandantas. For instance, Comandanta Ramona spoke in the central plaza of Mexico City and the National Indigenous Congress in 1996, and Comandanta Esther addressed the Mexican Congress in 2001 (CNI 1996, EZLN 2001, Wild 1998).

But Zapatista influence is not limited to the state of Chiapas. The movement has a central presence in the National Indigenous Congress (CNI), an independent organization encompassing representatives of many indigenous peoples across the country. During its Fifth National Congress - which took place in the UniTierra-Cideci, the Zapatista 
university in San Cristóbal de las Casas in May, 2017- the CNI and the EZLN selected an indigenous woman to run for the candidacy for the President of Mexico in the 2018 elections: María de Jesús Patricio (1963-), a traditional medicine woman and a human rights activist from the Nahua community of Tuxpan in the western state of Jalisco (CNI 2017, Henríquez 2017, Voces Feministas 2017). This is the very first time in Mexico that an indigenous woman will run for President.

Perhaps the only area in which the EZLN has not achieved any substantial improvements for women regards the recognition of land rights. Many of the communities that comprise the EZLN are also formal ejidos and comunidades agrarias, whose titles over land were granted to male heads of household by the federal government. However, even in the Zapatista communities that were created on occupied lands after the uprising in 1994 — which are not subject to federal agrarian laws-land rights have been mostly granted to males by Zapatista authorities. Zapatista families also continue to reproduce the practice of bequeathing most of the land to male children (Barmeyer 2009: 97-101, Klein 2015: 75-99). "The issue of gender inequality regarding land ownership is a very sensitive one for the EZLN," comments Javier, to whom I referred before, "and the movement has opted to avoid openly pressing the issue. The CCRI-CG knows that the support from the bases might be weakened considerably if communities were confronted in that area. The balance between landholdings and base support is very delicate...promoting women's access to land is a challenge that the movement has still to assume."7

Making an assessment of both the achievements and pending agendas regarding 
gender equality inside of the EZLN is a difficult task. As Klein puts it: "On the one hand, the changes Zapatista women have already experienced give them hope and confidence about victories still to come. On the other hand, there is an element of impatience stemming from having reached a kind of plateau. Women's deep loyalty to the EZLN brushes up against their frustration with a commitment to equality that has yet to be fulfilled and a vision of liberation that has yet to be realized" (2015: 234).

\section{Zapatista Autonomous Institutions}

Another way to understand the meaning of Zapatista autonomy is to look at how Zapatista communities relate to the federal and state governments. These autonomous communities have a whole set of self-government institutions that function independently from the existing state and federal systems (Klein 2015, Zaga 2015). Legislative, judicial, and executive powers are centered in the five JBGs, and several laws have been enacted to regulate life in autonomous communities. Among these are the Agrarian Law (which regulates land distribution to landless families), regulations on collective cooperatives, power restrictions over the EZLN's military branch, and the prohibition of alcohol, drugs, and prostitution (EZLN 1994, 1994b). Together with its government institutions and legal arrangements, the EZLN has consolidated a development agenda based on five principal axes: education, health, food and seed sovereignty, agroecology, and solidarity economy (EZLN 2003, 2014a, 2014b). I will explore these topics further in later chapters.

Zapatista communities do not participate in any federal or state government programs at all, which means that their inhabitants do not receive any funding or services — in some cases even basic services such as electricity and potable water-from 
the government. This practice is known as la resistencia (the resistance) among Zapatista communities, and has been a key element of their struggle since 1996, when the EZLN urged its support base to cancel any relationship involving aid from the Mexican state. This decision was made in the context of the failed peace negotiations between the EZLN and the federal government (1994-1996), and the intensification of the LIW against Zapatista communities (Barmeyer: 110-115).

Although this practice has defined the character of Zapatista autonomy since that time, it has also represented, according to Barmeyer, a real burden for Zapatista communities and a central source of division among community members. This is because the government has substantially increased the distribution of financial aid and social programs to non-Zapatista communities as part of its counter-insurgency strategy (Barmeyer 2009: 110-115, Baronnet 2009: 180-183, Zaga 2015). "The implementation of resistencia policies," writes Bermayer, "definitely marked a turning point. Designed to uphold a dignified self-image, the rejection of state resources increased the hardships of life in resistance and exacerbated existing tensions that eventually led to communal divisions. On top of having to support the guerrillas with a share of their work and harvest, the Zapatista base now also had to make do without outside help" (2009: 113). The EZLN has constantly denounced the fact that federal social programs such as Prospera — a conditional cash transfer program requiring children to attend school—are widely distributed to the most deprived communities in Chiapas at the same time that autonomous communities are systematically harassed by military and paramilitary groups. According to the EZLN, the distribution of those governmental programs seeks to 
capture potential Zapatista followers (EZLN 2016b).

The EZLN's resistance policies and its de facto independence from the Mexican state have also entailed a new dependence on international activists and the resources provided by NGOs (infrastructure, trainings, material), mostly from Europe and North America (Barmeyer 2009: 63, 153). Barmeyer explains that the need for outside assistance by NGOs became particularly pressing for the EZLN base communities when the guerrilla movement proscribed the acceptance of rural development programs offered by the Mexican state...the struggle for hegemony in the communities was exacerbated over the past decade as the state sought to boost its presence by building roads and deploying the army and special police units, but also by using development programs as a measure to incite communal strife...spurred on by this development, a new phase of cooperation between the autonomous communities and nongovernmental aid and solidarity groups began, by which outside actors gradually took on the role of service providers that had hitherto been assumed by the state (2009: 17-18).

The reorganization of the EZLN in 2003 - the creation of the five Caracoles and JBGs, and the definition of a clear development agenda — was a direct response to this situation of increased hardship among Zapatista communities and their growing dependence on external funding and activist work (see EZLN 2003). This does not imply —as the experience of DESMI demonstrates — that Zapatista autonomy no longer relies on the support of international NGOs and donor agencies; rather, the relationship between the movement and civil society has been redirected toward strengthening the 
Zapatista agenda for autonomy. As Zaga puts it, although the favorable results created by Zapatista institutions and policies have much to do with international donors, it is undeniable that the Zapatistas have appropriately employed this money for subsequent autonomous development (2015: 52).

Although no official data are available to measure whether the lives of Zapatistas have improved or not under autonomy, there are several case studies - together with EZLN documents - analyzing the impact that some particular Zapatista institutions and programs have had in different areas of development (see Baronnet et al. 2011, Cortés 2009, EZLN 2014a, 2014b, 2014c, 2014d, 2015, 2016a, Klein 2015, Zaga 2015).

For instance, in "Masked Development: Exploring the Hidden Benefits of the Zapatista Conflict" (2015), Zaga analyzes the long-term impact of the conflict on Zapatista communities. He measures three development components: (1) social backwardness index (encompassing education, health, basic services, and dwelling), (2) overcrowding rate, and (3) literacy rates. Zaga found that by 2010 the positive impact of the policies and institutions that Zapatistas have created had surpassed the negative effect of the civil conflict. More specifically, each additional year in conflict was associated with lower levels on three key variables: ${ }^{8}$ (a) the social backwardness index in a range between 5.9 and 2.9 percent; (b) the overcrowding rate, in a range between 1.33 and 2.68 percent; and (c) fertility, in a range between 1.8 and 3.62 percent. Additional years in the conflict were also positively but slightly associated with literacy rates of children aged 8 to 14 , in a range between 0.55 and 1.16 percent, particularly for boys (between 1.11 and 1.62 percent) (2015:52-53). It is worth noting that the impact of the conflict on literacy 
rates for girls is still insignificant (2015: 45). This outcome may reflect the fact that girls still lag considerably behind boys in access to education, even if gender equality is a crucial part of Zapatista educational policies (see Klein 2015).

Zaga concludes his analysis by stating that "the positive effect of the Zapatista institutions has nullified the negative effect of the conflict per se in the short run" (2015: 37), and he suggests two main policy implications:

First, bottom-up policies implemented by grass-root organizations, even in times of conflict, may represent an appropriate channel for encouraging endogenous economic development. In particular, CDD (community-driven development) strategies may symbolize a powerful tool for poverty reduction if development is genuinely driven by communities. Second, the Mexican government should recognize the Zapatista autonomy and its right for self-determination because, not only it is stated in the U.N. Declaration on the Rights of Indigenous People, but also the Zapatista institutions and policies have proved to be beneficial to its communities. For a viable roadmap, the San Andrés Accords signed between the government and the Zapatistas in 1996 should be complied and all kinds of police, military, and paramilitary harassment should be definitively suppressed (2015: 53).

The EZLN has also developed its own autonomous educational system. Baronnet estimates that by 2009 there were 510 Zapatista elementary and secondary schools, 1,300 promotores (teachers or instructors), and 16,100 students distributed throughout the five Caracoles (2009: 211-212). Castellanos calculates that more than 45,000 students have 
graduated from Zapatista schools (2014). There is also an autonomous university, the Universidad de la Tierra-Cideci, located on the edge of San Cristóbal de las Casas, where Zapatista students can continue with their education.

Perhaps the most challenging area of the autonomous educational system is primary education. Each community is required to have an elementary schoolsecondary and high schools are distributed among the autonomous municipalities and the Caracoles — and the number of students far surpasses the number of trained teachers and educational promoters available for each community. Adding to this overload of students, teachers frequently have to work under conditions that are far from ideal, such as overcrowded rooms (or no rooms at all) lack of materials, and pupils of mixed grades. Moreover, teachers do not receive a salary and often are paid in the form of other community members working their milpas for them. This mechanism of compensation is similar for health and agroecology promoters, and also for those in government positions such as the members of the JBGs.

According to Baronnet, a central advantage that Zapatista communities find in their autonomous educational system is that it promotes a pragmatic and ethical knowledge that reinforces the identity and dignity of students as members of Mexican, indigenous, peasant, and Zapatista communities (Baronnet 2009: 190). However, the main limitation of this system, according to Zaga, is that the federal government does not recognize these diplomas, which prevent students from accessing other educational institutions, particularly formal college education (2015: 17).

Another area in which the EZLN has made important achievements is health care. 
According to Castellanos, the EZLN has established four regional hospitals and dozens of clinics distributed across Zapatista territory, and has trained more than 1,100 midwives and 1,500 women herbalists (2014). Autonomous health services—labs, ultrasound, gynecology, odontology, and basic services, including preventive health—are not limited to Zapatistas but are open to all people in the area, which has gained the movement social support even from non-Zapatista communities ${ }^{9}$ (Zaga 2015: 18). The promotion of an agenda focused on the diversification of communities' diets, agroecology, and organic production is also viewed as a mechanism to prevent diseases and improve communities' environmental conditions.

Considering the high degree of social marginalization that exists in the state of Chiapas, particularly among indigenous communities (see Tables $\mathbf{2 , 3}$, and $\mathbf{6}$ ), all of these achievements of the EZLN represent a landmark for the region. As Klein puts it, "the Zapatista construction of indigenous autonomy has meant that rural villages in Chiapas have gained access to rudimentary health care and education, which they were previously denied" (2015: xix).

\section{Conclusion}

For indigenous communities in Chiapas, the presence of the EZLN has radically changed the meanings and possibilities of their own development. The model of indigenous autonomy that the EZLN has built in more than 30 years of struggle against what it calls the mal gobierno ("bad government") has reinforced the idea that for indigenous peoples in Chiapas, development under neoliberalism can only come from within their own communities. In this context, the process of building indigenous 
autonomy has become both the means and the ends of the Zapatista project. But what does autonomy mean for Zapatista communities? The definition of autonomy that the EZLN proposed during the negotiation of the San Andrés Accords ${ }^{10}$ is still quite alive among Zapatistas: "Autonomy is the concrete expression of exercising the right to selfdetermination, expressed within the framework of the Nation State. As a consequence, the indigenous peoples can decide on their own form of internal government as well as on their ways of political, social, economic, and cultural organization...The indigenous peoples' exercise of autonomy should contribute to the unity and democratization of the national life and should strengthen the country's sovereignty" (San Andrés Accords on Indigenous Rights and Culture 1996, quoted in Barmeyer 2009: 54).

In this chapter I have described some of the ways in which Zapatista communities have developed their autonomous government. In tangible terms, for Zapatistas autonomy means access to education, health, and basic services such as clean water, electricity, dry-composting latrines and low-smoke cooking stoves, food security, the organization of productive collectives, better conditions for women, and more democratic institutions, among many other things. A good way of summarizing the meaning of Zapatista autonomy is offered by Klein: "on a political level, autonomy is about selfdetermination. On an emotional level, it is about dignity" (2015: 172).

But Zapatista autonomy has also impacted the lives of non-Zapatista communities. As I will discuss in the following chapters, many of the development projects, social movements, and political initiatives in which non-Zapatista communities participate cannot be understood without recognizing the central role that the EZLN- 
along with the multiple organizations that closely work with it—plays in the region. As I learned during my stay in Chiapas, even among non-Zapatista communities the EZLN has become a beacon of resistance and development. Marcelino, a priest from a Tseltal community in Los Altos whom I interviewed in February 2016, gives an example of this relationship between Zapatista and non-Zapatista communities:

In the last couple of years you can see how many people who had left the EZLN, because things were very difficult and the resistance costs a lot, many of those people are approaching the movement again. People know very well that the Zapatistas will resist the mega-projects. The Zapatistas are also showing much more openness to people now than before. They have been organizing informational meetings to explain the situation that we, as communities, are facing with the mega-projects that the government wants to implement here, such as the dam that will inundate all that area that you can see through the window over there [he points out a canyon]. Here we just had one of those meetings. The EZ[LN] has been organizing those meetings in all four areas: the Selva, Norte, Los Altos, and Sur. Here, the EZ called for the meeting, and we, as the parish, did too. Many people from all around the region attended it. The meeting was very important and useful for the people here. People know that the EZ[LN] can resist, that the Zapatistas are very strong. Here, there is a great deal of respect for the movement. ${ }^{11}$

Similar to 1994, when multiple peasant organizations from different political affiliations occupied land after the Zapatista uprising (see Chapter 2), the EZLN 
continues to trace a path toward indigenous development in the state. One of the main bridges of communication between Zapatista and non-Zapatista communities is the organizations that collaborate with the EZLN, such as DESMI. Focusing on the agenda of food and seed sovereignty proposed by the project Guardians of Mother Earth and Seeds, the next chapters explore how development projects and political agendas emerge and are disseminated across the region. 


\section{CHAPTER FOUR}

"WE ARE THE PEOPLE OF MAIZE":

\section{SEED SOVEREIGNTY AND THE BATTLE FOR THE COMMONS}

Their flesh was merely yellow ears of maize and white ears of maize. Mere food were the legs and arms of humanity, of our first mothers and fathers.

Popol Vuh: Sacred Book of the Quiché Maya People ${ }^{l}$

(CE 1000-1500, approx.)

We are the people of maize. Isabela, Tsotsil from San Andrés

Agrochemicals have reached the soul of our ancestors because they touch our seeds.

Juan, Tseltal from Tenejapa

Without their seeds communities are condemned to extinction.

Mariano, DESMI

The importance that native seeds, and particularly maize, have for peasant communities in Chiapas makes seeds an essential reference when people try to explain who they are, where they come from, and what they believe in. As I explore in this chapter, the idea of seed and food sovereignty that is taking form among these communities gives cohesion to the multiple meanings that native seeds hold for their members. Yet seed sovereignty in Chiapas is not only about seeds. It also speaks about what these communities are, and how they perceive themselves as "people of maize" who belong to the land.

I have argued that seed systems ${ }^{2}$ are acquiring political relevance in a neoliberal context in which seed regulation and commodification are advancing toward the 
consolidation of privatized industrial global seed systems. Largely controlled by a few transnational corporations and increasingly governed by international schemes of intellectual property rights and seed certification laws, the ongoing industrialization and privatization of seeds may pose significant risks to native seed systems. How peasants perceive and respond to those threats varies greatly among communities. However, those potential threats have triggered the development of local seed and food sovereignty agendas all around the world, including in Chiapas. One consequence of this countermovement has been the re-signification - in political, cultural, economic, and biodiversity terms — of native seed systems as part of the commons, which must be protected against their privatization. Focusing on Chiapas, this chapter empirically analyzes these developments. It examines the increasingly contested relationship between formal (industrial) and informal (peasant or native) seed systems under neoliberalism. It also discusses how the idea of seed sovereignty has emerged among the communities in Chiapas I worked with, and how it is evolving.

In the first part of this chapter, I explore some of the spiritual, cultural, and material meanings that native seeds hold for peasant communities in Chiapas. As I discuss in the following pages, communities' native seed systems are not merely the material foundation of their subsistence agriculture and food security. Rather, native seeds also embody deeply rooted spiritual and cultural meanings that communities assign to them. Together, these meanings play a critical role in the evolution of local seed systems and also in the ways that communities understand themselves as indigenous peasants. 
Closely related to the reproduction of native seed systems is the issue of food security, which in peasant communities in Chiapas is inextricably linked to the milpaalso termed the "maize field," a polyculture system centered on maize (Nigh and Diemont 2013: 45). This chapter introduces the milpa system and analyzes some of the challenges communities face in order to preserve and reproduce the main source of their food. Environmental degradation, land and labor scarcity, the increasing dependence of households on cash income, and changes in diets are some of the topics analyzed throughout the chapter. It is important to identify and discuss the impacts of these phenomena on communities' food security in order to evaluate the challenges they might pose to the emerging project of food and seed sovereignty.

Taking into account how spiritual, cultural, and material meanings shape the everyday agricultural practices of peasant communities is necessary in order to extend our comprehension of how communities appreciate native seeds and the milpa as essential components of their commons. This understanding is also useful for analyzing how communities perceive and respond to the global processes of industrialization of agriculture and privatization of seed systems. The second part of this chapter delves into these issues, discussing some of the responses that peasant communities have developed to challenge such processes of capital advancement. This chapter establishes the context for analyzing DESMI's Guardians of Mother Earth and Seeds Project, which is the focus of Chapter 6. 


\section{Spiritual, Material, and Cultural Meanings of Native Seeds Systems}

\section{Sacred Seeds: Mayan Theology and The Mayan Altar Ceremony}

The Mayan Altar ceremony is one of the most popular and widespread spiritual rituals performed today by indigenous communities across the region of conflict in Chiapas. According to Xaw, a non-Zapatista Tseltal male in his fifties and a practitioner of the Mayan theology, ${ }^{3}$ this syncretic ceremony is unique because it merges, as do many other indigenous rituals in the region, traditional symbolism and practices with contemporary meanings and objectives. The origins of this ceremony are unknown, but it is considered to be a pre-Columbian rite that was born in the Mayan lands of Guatemala. It acquired renewed relevance in the late 1990s with the development of the Indian Theology (see footnote 3). However, Jxun, a Zapatista Tseltal man in his forties and also a practitioner of the Mayan theology, emphasizes, "what today is known as the Mayan Altar, at least in the diocese, ${ }^{4}$ is a renewed and sophisticated ritual that reflects the political and intellectual re-signification of what it means to be indigenous in Chiapas." There are three important elements that today converge in this ceremony, accordingly to Xaw: "the traditional practices and beliefs of indigenous peoples, which have always been there; the Zapatista struggle for indigenous autonomy with all its ideas about indigenous rights, justice, freedom, and a dignified life; and the diocesan commitment to support the indigenous peoples in their path [el compromiso de acompañar a los pueblos indigenas en su caminar], a commitment that comes from jTatik Samuel [Bishop Samuel Ruiz] and the adoption by the diocese of 'la opción por los pobres' [the preferential option for the poor, a liberation theology doctrine]." 
It is valuable to describe the Mayan Altar ceremony here because of the central role played by native seeds, which are thought to embody the souls and spirits-ch'ulel in Tseltal and Tsotsil — of communities' ancestors and deities. The description of the Mayan Altar helps to illustrate some of the collective meanings that communities assign to their native seeds. ${ }^{6}$ As I will discuss later in this chapter, these cultural and spiritual meanings are essential elements underlying the longstanding practices of seed inheritance and exchange within communities, and with them the evolution of native seed systems and biodiversity.

The objective of the Mayan Altar ceremony is to engage in a dialogue with communities' ancestors, asking them for advice and guidance when people need to make important decisions or resolve difficulties. According to Jxun, asking help from people's ancestors and deities is a practice that has accompanied indigenous communities for centuries, and it is still present in the everyday life of these people, independently of the form it might take — there are many different rites, ceremonies, and prayers for this purpose. It is worth noting that when individuals refer to their ancestors, it includes both their communities' ancestors and their collective ancestors as Mayan peoples. This practice reflects the degree to which people perceive themselves as members of a greater, ancient community that transcends the story of singular families and the geographical and ethnic limits of individual communities. This is why people from many different communities might participate in the same event.

The ceremony is led by indigenous spiritual leaders who might be either deacons of the diocese, members of communities' councils of elders, or practitioners who are 
training to become spiritual leaders, as in the case of Jxun and Xaw. The ceremony begins with the arrangement of the Mayan Altar. There are many different versions of the altar, but the most popular in this region consists of a 10-foot wide circle traced on the floor. The circle symbolizes the cosmos, the earth, and the milpa. It is covered with pine needles and divided into quarters, representing the four cardinal directions: East, West, North, and South. They also denote the four guardians, the four winds, and the four pillars of humanity.

For each cardinal point a color is assigned: red for the East, black for the West, white for the North, and yellow for the South. Each quarter is covered with flowers and native maize seeds of the same color. The red in the East represents the sun, the birth of humanity, the possibility of germination, the power of fire, and the intensity of blood. The black West symbolizes the night, when the sun rests in the underworld. There, the sun travels through the dark energies of death, but also through the roots of life. The underworld is the womb where humanity is recreated. It is there where transformation occurs, and where humans find their own souls. Black maize also represents the hair color of the Mayan people. The white North is the place where these communities' ancestors come from. It is the dimension that is inhabited by the collective spirits of communities. Frosts, diseases, and humiliation come from the North. But the color white also represents the germinated seeds and the original bones of humans. The yellow South is the warm house of all seeds, the source of life of every living being. It is in the South where the guardians of seeds live. Yellow maize also represents femininity, fertility, and the color of the skin of the Mayan people. At the center of the altar is a small pile of dirt, 
representing Mother Earth.

Crossing the altar is the East-West line, which recreates the path of deities. The North-South line represents the path of humanity. The center of the altar, where both lines intersect with Mother Earth, is where humans and deities encounter each other, and it symbolizes the ideal of Lekil Kuxlejal-Ich'el ta muk', an indigenous Tseltal and Tsotsil term meaning the process of building a life lived in dignity, justice, and harmony (see López Intzín 2013 for a comprehensive analysis of the concept). This is a relatively novel concept that has acquired considerable relevance in indigenous communities since the Zapatista uprising in 1994.

Surrounding the circle are candles arranged in concentric rings. They provide the light for transitioning from the material to the spiritual dimension. The smoke of the burning copal—incense — represents the essence of spirits, and its inhalation allows people to be embodied by those souls. When a deacon leads the ceremony, or when it takes place in a church parish, an image of a crucified Christ and an open bible are placed in the altar. They symbolize the confluence of Catholicism and Mayan spirituality, which gave birth to the Indian Theology in the 1990s (see footnote 3).

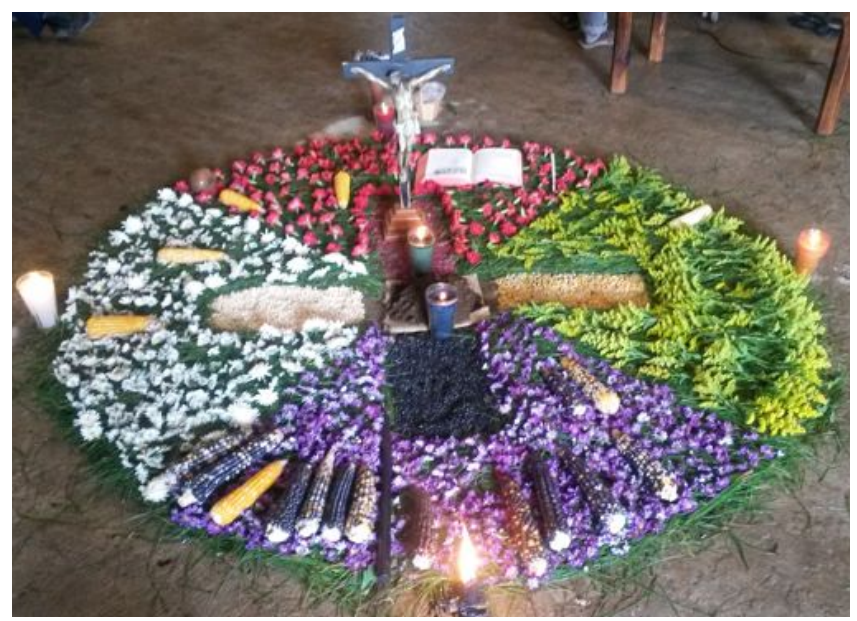




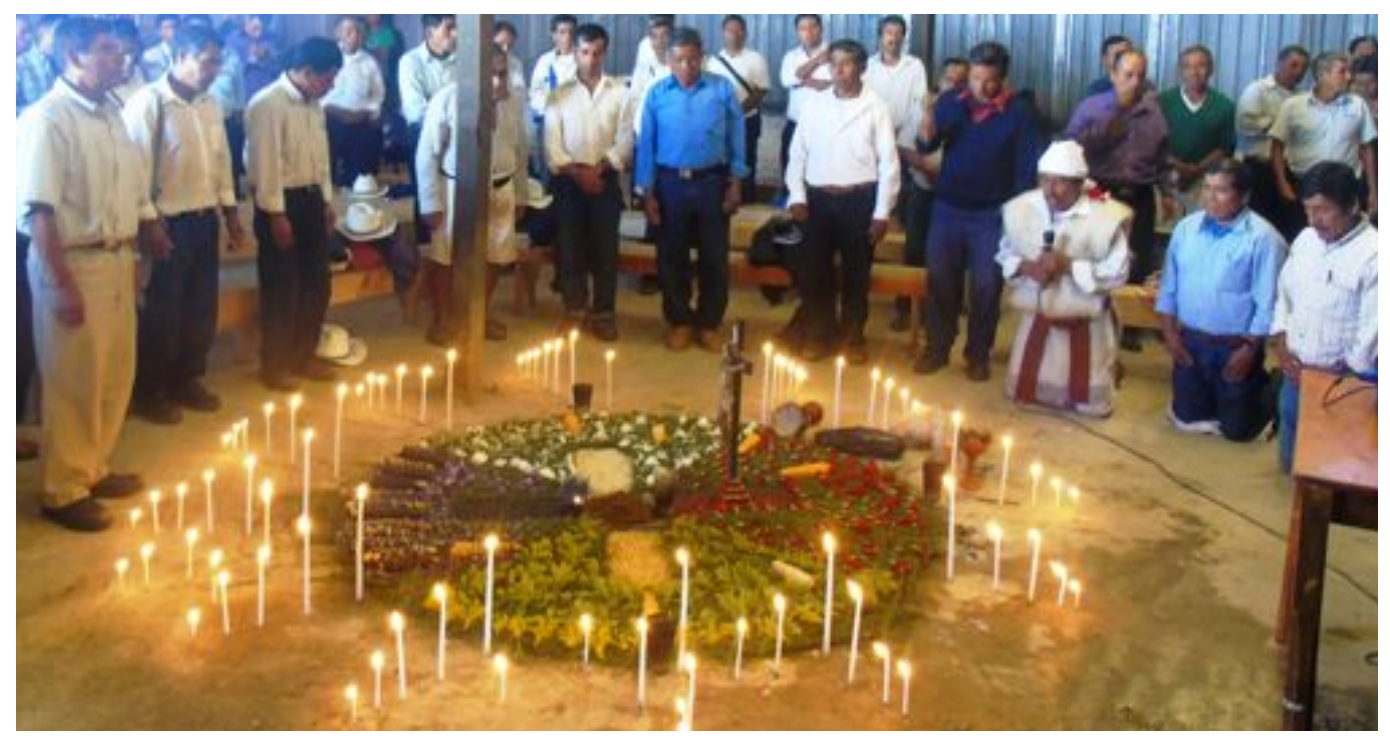

Figure 6. The Mayan Altar Ceremony. Native maize seeds are thought to embody the souls and spirits, or ch'ulel, of communities' ancestors and deities. Photographs by author.

According to Jxun, who has focused most of his work on the study and interpretation of indigenous philosophies and spiritual practices, these rituals, and the beliefs that give life to them, are far from being fixed in the past. Instead, they are alive and very fluid, which means that they are "used and understood," in his words, according to the everyday needs of communities. "You can see how flexible some of these rituals are because many people are using them in different spaces with many different purposes. Some of them have been there for generations, some others even disappeared for a while but then came back with new meanings, as in the case of the Mayan Altar," explains Jxun. "Mayan theology is very fashionable these days," he says, laughing, because it helps communities to interpret and explain their own reality as indigenous peoples.

\section{Strategic Essentialism?}

The Mayan Altar ceremony offers an excellent example of how communities can reinterpret, and even recreate, their own spiritual practices and indigenous identities 
in the service of political discourses that seek to build internal cohesion at the community level — in this case around Mayan identity and native seeds — while also creating and consolidating alliances with external actors. As Jxun and Xaw suggest, the Mayan Altar ceremony is a concrete illustration of how the political agendas of diverse actors - the diocese of San Cristóbal, the Zapatista movement, and even the national and international seed sovereignty movement—converge, bringing new meanings and relevance to some of the pre-existing spiritual and ceremonial practices of these communities.

As I will explore further in this and the following chapters, the centrality that the Mayan Altar and native seeds have gained in the last two decades cannot be understood without keeping in mind the increasing contention around seeds under neoliberalism. The fusion in one particular ceremony of elements of Mayan identity, Indian Theology, and the concepts of Mother Earth and Lekil Kuxlejal-Ich'el ta muk' has to be viewed as the manifestation of a concrete contemporary political agenda. This agenda encompasses elements from the Liberation Theology, Pope Francis's environmentalism, Zapatista autonomy, and Mayan alliances for protecting native maize in a national and global context where GMOs are rapidly expanding. I would argue that the Mayan Altar ceremony reflects the range of actors and agendas that constitute the seed sovereignty movement in the indigenous area of the state of Chiapas.

Jxun and Xaw accurately point out that this and other similar ceremonies and cultural expressions reflect the evolution of indigenous peoples in Chiapas in the last few decades. Therefore, instead of being interpreted as pre-Columbian rituals fixed in the past, the meanings of these cultural expressions should be analyzed in the contemporary 
political context of the regional indigenous movement and the recreation of identity. In Chapter 3 I discussed how the Zapatista movement has continually refined its own identity as an indigenous social movement. Two of the most concrete examples of this exercise are the clear distancing of the movement from the Mexican state, and the creation of a particular model of autonomous government encompassing education, health, environmentalism and agroecology, solidarity economy, and women rights. In other words, the EZLN has not only undermined the historical paternalistic relationship between the Mexican state and indigenous communities in the region, but through this process it has also proposed an alternative model of being indigenous. As I emphasized above, in this process of remaking indigenous Zapatista identity, other social movements, activist groups, and donor agencies have played an essential role (Barmeyer 2009, Olesen 2005).

Also worth highlighting here is the evolution of the anti-capitalist character that the Zapatista movement has developed in the last two decades. It would be a mistake to interpret this stance as an attempt "to go back to nature" or to recreate "primitive," native pre-capitalist societies (see Kuper 2003 for a discussion on essentialism and the "return of the native"). If the intellectual and political development of the Zapatista movement is carefully analyzed, it becomes apparent that the point at which the EZLN first changed its focus from the Mexican state to the macro-structures of capitalism was when the Mexican government failed to recognize the San Andrés Accords and escalated the lowintensity war, which eliminated any possibility to solve the conflict through institutional channels. Since then, the EZLN has focused most of its efforts on creating an 
autonomous model of indigenous development, which includes a political redefinition of indigenous identity in relation to capitalism and the capitalist state. The Zapatista movement continuously reiterates that indigenous peoples have no real possibilities to develop under capitalism (EZLN 2015). As Rodolfo Stavenhagen points out, colonization, dispossession, exploitation, exclusion, acculturation, and genocide have been some of the implications of capitalist expansion for indigenous peoples (2013: 46). This is true not only in the distant colonial past. The recent civil war in Guatemala (19601996), in which more than 150,000 peoples were killed, the large majority of them Mayan people (Booth et al. 2014: 181), and the placement of one third of the Mexican army in the area of conflict in Chiapas (Klein 2015: 112), both indicate that ethnicity still plays a central role in the definition of citizenship and civil rights (see Mamdani for an excellent analysis of race and ethnicity as two salient political identities that are a result of the process of state formation; 2001:19-39).

In this adverse context marked by war and repression against indigenous peoples, the Zapatista movement has survived in part because of the strong political alliances that the EZLN has built with other international actors. This includes international social movements, activist groups, and donor agencies that have directly contributed to the Zapatista movement with financial and technical resources and civil support, such as the international civil society brigades in Zapatista territory (Barmeyer 2009, Olesen 2005), as well as the European Union and its demand that the Mexican government improve civil rights conditions in Chiapas as a prerequisite to signing a trade agreement (Sanahuja 2000: 15-20). 
In turn, the construction of these political alliances has been possible in an international context where the "indigenous-peoples rhetoric" has gained centrality. As Kuper (2003) suggests, the spread of indigenous social movements around the world in the 1990 s cannot be explained without taking into account the favorable framework that the UN created with the promulgation in 1989 of ILO Convention no. 169, which recognizes the rights of indigenous peoples to participate in the making of decisions that affect them, and then the declaration of the UN Decade for Indigenous Peoples (19952004). These events not only established a favorable international legal framework for the rights of indigenous peoples, but they also helped to define a shared discourse for their social movements, what Kuper calls the "indigenous-people rhetoric." Kuper argues that this rhetoric has led to the romanticization of indigenous movements through equating indigenous people to ancestral culture, innate environmentalism, and historical collective rights that precede modern, industrialized societies (2003: 389-390).

In this context, is "strategic essentialism"- the deliberate use of "nativeness" or "indigeneity" to gain strategic advantage in the national and international realm ${ }^{7}$ a force behind the contemporary reinterpretation of cultural and political identities of indigenous communities in Chiapas? While the mobilization of indigenous identity in relation to external actors is certainly at play here, it would be an oversimplification to argue that the remaking of indigenous identity in contemporary Chiapas responds exclusively to this new favorable international framework for indigenous social movements. A more important force behind this process of recreation of ethnicity and identity is the regional political development of indigenous communities since the 1970s. 
In order to establish regional alliances and political, economic, and religious organizations, communities had to find a common ground that would transcend the particularities of individual communities and ethnic groups. That common ground has been the Mayan identity, around which diverse political agendas have been organized. Some of the most salient agendas are the Zapatista project of indigenous autonomy, the Mayan theology, and more recently, seed sovereignty and the defense of native maize and the milpa system. In order to build their constituency, the actors leading those political projects - the EZLN, the diocese of San Cristóbal, and local organizations such as DESMI—-have selectively chosen, capitalized on, and politicized cultural elements that are inherent to these indigenous communities. The idea of the defense and protection of native seeds - now central to the Mayan Altar ceremony — as a political framework is a concrete example of this process. However, it would be a mistake to argue that this politicization of cultural and spiritual elements reduces or eliminates the power, legitimacy, and meanings that they have for indigenous communities. Rather, it is precisely because of the centrality and vitality they hold that these cultural elements can be easily translated into political ideas that mobilize entire indigenous communities.

Finally, as the evolution of the Zapatista movement indicates, these cultural and spiritual redefinitions must also be analyzed in relation to the impacts of neoliberalism on the historical relationship between the state and indigenous peoples, and the peasantry in broader terms (Escobar and Álvarez 2018, Veltmeyer and Petras 2008, Stavenhagen 2013). In his analysis of the Zapatista uprising in 1994, Gunderson (2018) points out that the particular timing of the major indigenous revolts that have taken place in Chiapas 
since the $16^{\text {th }}$ century was determined by changes in systemic cycles of capital accumulation. As the capitalist system changes, the mechanisms of social stratification, the identities attached to such mechanisms, and the strategies of resistance of oppressed groups change as well. In the following sections of this chapter, I analyze how the cultural and material relationships of communities with their native seeds have been redefined in response to their interaction with external actors and dynamics, including the expansion of industrial agriculture.

\section{Native Maize, The Milpa System, and Subsistence Agriculture}

When I ask people in Chiapas how they perceive themselves as peasants, mestizo and indigenous people alike invariably refer to maize and the milpa. "We live from the maize we cultivate in our milpa," says Susana, a non-Zapatista mestiza woman with four children from Teopisca. "Here in my community all people live from their milpas, we mainly produce maize and beans. ${ }^{\prime 8}$ Ramiro, a young non-Zapatista mestizo father of two from Venustiano Carranza, says: "my family eats from the milpa, from the land that our parents bequeathed to us. It is the milpa where our food comes from." Agustina, a Zapatista Cho'l woman in her thirties from Tumbalá, explains: "in our communities, the first food that we give to children after their mother's milk is atole made from maize."10

Beyond food security issues, most indigenous peasants I interviewed would also refer to the cultural and historical relevance that maize has for Mayan communities. "Maize is our guardian. It has always been in this way," says José, a non-Zapatista Tseltal man in his late sixties from Cancuc. "We produce and eat maize from our milpas; that is what keeps us alive." ${ }^{11}$ Juanita, an older Zapatista Tseltal woman from Tenejapa, 
concurs: "maize is the only food that we always eat, and we cannot live without it. Maize is like our soul, our ch'ulel, as we call it."12 These cultural perceptions are transmitted from generation to generation. "Since we were very young kids we learned that we depend on maize for our existence. 'You have to take care of it.' That is what my grandparents always tell us,"13 says Lorenzo, a young Zapatista Tsotsil man from Zinacantán.

A few people even refer indirectly to the Popol Vuh - a Mayan pre-Columbian narrative recounting the creation of Earth and humanity, which is between 1,000-1,500 years old. "There are very old texts that explain our story as Mayan peoples. It is said that we were created from maize," explains Loxa, a 23-year old Tsotsil girl whom I met in the Caracol of Oventic, and one of the two educational promoters in her community. "We have always lived on these lands because it was here where maize was first found by the gods who created humanity. My grandmother always says that gods used maize for creating us, humans," ${ }^{\prime 14}$ she adds. Using different words, Isabela, an older non-Zapatista Tsotsil woman from San Andrés who does not remember her own age, expresses a similar idea: "we are the people of maize. We eat maize because we were created from maize. Our ancestors were made from maize, and so are we."15

The fact that very similar responses come from people of different ages, genders, ethnicities, and political affiliations in this region suggests that these narratives are collective and deeply rooted within communities. The perception these communities have of themselves as "peoples of maize who live from their milpas" is inherent to peasant communities in Chiapas - and in different degrees to many peasant communities in the 
rest of Mesoamerica, a region now recognized as the center of origin of maize and the milpa system, particularly Mexico (Buckler and Stevens 2005, Piperno et al. 2009, Wilkes 2004).

These are not abstract perceptions, however; they have material foundations in the everyday life of these communities. Today, almost all peasants in Chiapas who have access to land continue to work their milpas and produce maize for their own subsistence. ${ }^{16}$ This is the case even if peasants have other income sources such as the production of cash crops (e.g., coffee), government subsidies, remittances from migrants, or wages from the labor market (see Eakin et al. 2014a, Eakin et al. 2015 for a comparison of Chiapas, the State of Mexico, and Sinaloa). As Eakin et al. point out in their study of peasant maize production in Chiapas after 20 years of NAFTA, "subsistence production remains a core component of farming, regardless of the degree of commercial participation of the household in maize markets" (2014a: 146).

Working the milpa and producing maize for self-consumption are the very same material foundations that have sustained the Mayan civilization for millennia, and they are inextricably related to the origin of maize and its domestication by Mesoamerican peoples, roughly 9,000 years ago, and then to the development of the milpa system (Buckler and Stevens 2005: 71, Piperno et al. 2009: 5019, Wilkes 2004: 9). The milpa is a swidden agriculture and resource management system that was fully developed by Mesoamerican peoples about 2,000 years ago, although its actual origins date from 4,000-3,000 years ago (Ford and Nigh 2009: 223). The milpa traditionally consists of maize intercropped with other species, commonly beans and squash, but might also 
incorporate other crops selected from over a hundred species domesticated in preColumbian times (chile, cacao, tomato, tobacco, vanilla, chayote, papaya, potato, avocado, sunflower) and complemented today by newer species from all over the world (Nigh and Diemont 2013: 46, Wilkes 2004: 13). An example of what a diversified milpa in Los Altos looks like is given by Marcelo, a Zapatista Tseltal man from Cancuc: "we cultivate maize and beans from different varieties, but our milpa also gives us some vegetables and herbs; for instance, we have coriander, squash, tomatoes, chayote, chilacayote, and many herbs grow there too. We also have some fruit trees: peaches, apples, pears, and plums. That is essentially what our milpa gives us. ${ }^{17}$ Doña Rosario, a mestiza non-Zapatista woman from Teopisca, offers a similar response: "in our milpa we have maize and beans; that is the main thing we have. But we also have chayotes, sometimes squash, some green and red tomatoes, and lemon trees. In our solar [a vegetable garden located in a household's patio] we have other things like chile, onion, garlic, and some herbs, to complement."

However, the traditional milpa system, also called the Mayan forest garden, is not reducible to the maize field alone (Ford and Nigh 2009, Nigh and Diemont 2013). Rather, it is a complex natural resource management system consisting of four interconnected ecozones: milpa, acahual or secondary forest (a managed successional forest), primary forest, and water systems. The milpa is a successional agroforestry system that centers on felling primary or secondary forest, burning the dried vegetation, and planting maize and other species selected in the clearing. After several years of cultivation the land is left to develop into secondary forest. Historically, peasants planted and harvested a milpa for 
two to five consecutive years, then allowed it to regrow with spontaneous forest species (known as acahual). Meanwhile, peasants started the cycle again using a different area of secondary or primary forest to cultivate a new milpa. When regrowth in the acahual reached a height of four to seven meters (usually within eight to 14 years, depending on the region), they cleared and burned the area for a second round of cultivation, or allowed it to regenerate into mature forest, a process which requires 20 years or more of fallowing (Nations and Nigh 1980: 8). The sustainable exploitation and preservation of those ecozones allowed communities to reproduce this "diverse, long-term, stable food production system" for millennia (Nations and Nigh 1980: 2). The milpa system proved to be adaptable to the extremely varied local ecosystems and cultures of Mesoamerica, and it can be found from sea level to highlands above 3,000 meters, and from tropical humid environments to semi-desert conditions (Nigh and Diemont 2013: 46, Perales and Golicher 2014: 2).

Since the last century, however, the resilience of the milpa system has been seriously threatened. This is because the organic, long-term cycle of cultivation and fallow, which allowed the sustainable balance among the four ecozones, has been considerably disrupted — limited or even eliminated altogether in some areas, including many of the communities covered in this study. Increasing the cropping frequency-that is, the length of time a parcel of land is cropped compared to the time it is left fallowhas become a common strategy of agricultural intensification among shifting cultivation farmers across the Mayan region (Lawrence et al. 2007: 20696, Nigh and Diemont 2013: 49, Ochoa-Gaona and González-Espinosa 1999: 31, Radel et al. 2012: 205, Schmook 
2010: 234). In the study region, this intensification may be related to population density and pressures on scarce land (Ochoa-Gaona and González-Espinosa 1999: 19).

A good example of this process is given by Marcelo, whom I referred to above: "in my family [he refers to his extended family, who together share four hectares] we now have three spaces in which we rotate the milpa. We work the land for three or four [annual] cycles and then we allow it to rest for two or three years. We cannot give it more time because we don't have enough land. We need to keep producing our food."19

There are no reliable data about when exactly the deterioration of the milpa system began in the region-according to Nations and Nigh, most indigenous technological knowledge was lost during the process of colonization of Mayan people by Europeans ${ }^{20}$ (Nations and Nigh 1980) — but the inflexion point may be around the 1960s or $1970 \mathrm{~s} .{ }^{21}$ Among the most relevant factors influencing this outcome are population growth, land scarcity, intensive use of agrochemicals, near-monocrop production, expansion of livestock grazing, chronic deforestation, and the increasing incorporation of peasants into labor markets, including long-term migration (see Busch and Geohegan 2010, Diemont et al. 2005, Lawrence et al. 2007, Nigh and Diemont 2013, Ochoa-Gaona and González-Espinosa 1999, Radel et al. 2012, Schmook 2010). Manuel, a Zapatista Tsotsil man in his forties from Zinacantán, offers an example of how some of these dynamics work together in his community:

Although the milpa continues to be the main source of food in my community, the area of cultivation and the production of food have been diminished. Why? It is because many people now have to leave the community. Before, many people 
worked as seasonal jornaleros [laborers] in the coffee plantations, but it was only for one season, and after that they used to come back to work their milpas. Now, however, people leave the community for half a year, or even for one or two years. They leave the family here and go to Mexico City, to the Yucatan Peninsula, or to the North; many of them have even gone to the U.S. to work there as braceros. In consequence, fewer people work the land here...Many families have introduced livestock as an alternative, because it is less work and it assures you some money in case of emergencies. It is also a good option because you can put your animals in places where the milpa no longer produces [because the land is deteriorated] and you can keep your land occupied. Each family has its own animals, even if they only have one or two cows, but everyone tries to have animals. That has reduced a lot of the area for cultivation. You can see how it impacts the production of food because now the maize crop does not last the whole year, and between June and September, maybe until October, people need to buy maize to complement their harvests. That happens with my family too-we begin buying maize around June or July, sometimes even earlier because it is cheaper before everyone starts buying it. ${ }^{22}$

Underlying these phenomena, as the case of Manuel exemplifies, is a lack of economic incentives to peasant households for maintaining a diversified organic milpa system, which requires a very intensive use of labor and specialized technical knowledge (Busch and Geohegan 2010, Ford and Nigh 2009, Nations and Nigh 1980, Nigh and Diemont 2013). In a neoliberal context in which deprioritization of peasant agriculture is 
the norm, peasant communities have been forced to reduce the costs of their food security to the minimum possible. This has entailed - as many communities in this study showkeeping the milpa at its most basic level, which literally means "a maize field" sustained through the use of agrochemicals. "The current situation of peasants is very difficult," comments the researcher Hugo Perales of El Colegio de la Frontera Sur (Ecosur) in San Cristóbal. "Peasants need to survive, they need money. What peasants want today is food security at the lowest cost possible, as low as it can be. ${ }^{23}$ I will discuss these issues and their implications for communities in depth in further sections. What is worth nothing here is the centrality that native maize and the milpa system have in the subsistence of these peasant communities.

\section{Community Seed Systems: Seed Inheritance, Exchange, and Intellectual Property}

\section{Rights}

Like few other cultural elements, native seeds represent the essence of peasant communities in Chiapas and, at least metaphorically, they recount the origins and history of entire families and communities. Local seed systems speak to the evolution of these communities' biodiversity, agricultural practices, diets, and cultural and spiritual beliefs.

Underlying these elements are the longstanding practices of seed inheritance, exchange, and reproduction that prevail in all peasant communities in the region of study — indeed, this is an enduring practice in most peasant communities across Chiapas, in Mexico, and in other parts of the world (Camou Guerrero 2015, Pons 2012, Siegel and Betz 2016, Sotelo 2017). On this issue, in the region of study, the differences between mestizo and indigenous communities, and even among ethnolinguistic groups, are subtle 
and apparently minor. Nevertheless, it is valuable to keep them in mind because different perceptions and practices have specific effects on communities' seed systems (Benz et al. 2007, Brush and Perales 2007, Perales et al. 2005). Some of those effects are related to native seed diversity, the use of commercial varieties (hybrid or improved seeds), experimentation with different crops, the use of agrochemicals, and degree to which people turn to the market to complement the agricultural cycle of the milpa during the meses flacos - the "lean months." This is the period of the year in which households no longer have maize left from their own harvest and need to buy it for their consumption, generally between July and September, although it can last from June to October.

As the Mayan Altar ceremony illustrates, for indigenous communities native seeds embody the spirits and souls — the ch'ulel — of their ancestors. According to Alux, a fifty-seven year old non-Zapatista Tseltal man from Cancuc, each generation is responsible for keeping alive its communities' ancestors through the reproduction of inherited native seeds in the agricultural cycle. They do this by sowing, tending, harvesting, and selecting seed and preserving it for the next cycle. This process is known as informal or traditional seed systems, which I will discuss below. "When people marry," Alux remarks, "they inherit native maize and bean seeds from their parents. The new couple uses those seeds to start their own milpa. The milpa is the subsistence base [la base de subsistencia] of the new family, where its food will come from. My parents received seeds from my grandparents. When I married, my father gave me seeds, and then I passed them to my children, and they will pass those same seeds to their children too. ${ }^{24}$ Even when people do not receive land from their parents - as in the case of most 
women, or when they migrate to other regions to form new communities - most peasants still inherit seeds that they will bring with them to their new lands. In this way, the inheritance and reproduction of native seeds symbolize both the union of the couple and the reproduction of the community with its millennial agricultural and spiritual practices.

In most mestizo communities in this region, such as Teopisca and Venustiano Carranza, spiritual bonds to native seeds are weaker than in indigenous communities (Brush and Perales 2007, Perales et al. 2005). However, seed inheritance from family members remains a fundamental source of seeds for new families. Seed inheritance also plays an important role in reinforcing peasant identity in these communities. Don Antonio, a non-Zapatista mestizo peasant from Teopisca in his late sixties who still works his milpa, says that seven of his nine children started their own milpas using native seeds coming from within the family. "Only my two youngest children, my son and my daughter, have not received seeds because they are living in the city [San Cristóbal]; they are studying there. Let's see what happens after they finish their studies. If they won't work the land, they do not need the seeds. ${ }^{, 25}$ A similar perspective comes from Diego, a young Tsotsil male from Zinacantán who works in a local NGO in San Cristóbal. Diego repeatedly told me that he needed to go back to his community to start his own milpa because, otherwise, he would not receive seeds from his parents. "My parents, they even don't remember me anymore [mis papas ya ni se acuerdan de mi]," he frequently said laughing, which is a very relative perception because Diego spends all of his weekends in his community at his parents' house. ${ }^{26}$ These two statements emphasize the symbolic relationship between seed inheritance and the reproduction of these families as members 
of peasant communities. Native seeds, and along with them communities' ancestors, are only inherited by those who will remain on the land.

The governmental land tenure structures of ejidos and comunidades indigenas reinforce these cultural norms. Only those families who work their parcelas are able to preserve their right to land and resources within the ejido or comunidad. If people live outside of their community and want to keep their land rights, they have to hire jornaleros (daily waged laborers) to work their parcela, otherwise will they lose their right to the field. Moreover, participation in the community assembly and other leadership positions is reserved for formal ejidatarios or comuneros - heads of household over eighteen who officially hold the title of their family parcels. Many communities also contain households with varying degrees of access to land but without formal land rights (Radel et al. 2012: 109, 112, 115). Similar to the logic of seed inheritance, only those who keep working their lands are considered to be full members of their ejido or community.

The centrality that kinship relations have in the reproduction of these communities' native seed systems is reflected in the fact that today between 90 and 95 percent of all the seeds planted in this region still originate from within the community ${ }^{27}$ (see Brush and Perales 2007: 217-219 for a comparative study on maize diversity among indigneous and mestizo communities located at different altitudes in Chiapas). Indeed, the acquisition of maize and beans - the two essential crops in the region - is mostly limited to inheritance and exchange, which means that these seeds are practically removed from commercial circuits (see also Badstue et al. 2007, 2006, Sotelo 2017). 
“Here in the community we don't have seeds from outside. We have never even received seeds from government programs," says Petul, a Zapatista Tseltal man from Cancuc. "What we do here is that sometimes we exchange seeds among families, but we only do so with local seeds, seeds that come from within the community - that is, native seeds." He concludes, "fortunately, we are still self-sustaining for seed. We sow here, harvest here, and reproduce here the seeds that we have in our community." 28

The few seeds that do come from outside of the communities are hybrid or improved seeds of commercial crops (e.g., hybrid maize, coffee, chile), and some varieties that people might want to experiment with and cannot find in their communities (e.g., vegetables and fruits, maize or beans from other regions). Marcela, a non-Zapatista mestiza peasant from Teopisca, exemplifies this dynamic: "Here in the community we do not buy seeds from outside. We produce almost everything we eat. Sometimes, however, if we want something new, we will buy the seeds. For example, when my husband bought broccoli and beets, we sowed the seeds and they worked out. But almost everything comes from within the community." ${ }^{29}$ Experimentation is a central part of trying new seeds, which, preferably, should come (whether bought or exchanged) from a trustworthy source — a neighboring community, friends, or the local market (Badstue et al. 2007: 1580, 2006: 250, Perales 2016: 274). "These are the children of the mazorcas [maize cobs] that Mariano [a member of DESMI] brought me from Guatemala last year," comments Manuel, a Zapatista member of the agroecology committee in Oventic. "I have been experimenting with them. They worked out well and my brother asked me to share some seeds with him. This year I'll mix them with my own seeds; let's see what 
results." 30

The perception that "almost everything comes from within the community" is accurate, not only because these peasants mainly use native seeds, but also in the sense that once those external seeds are acquired and prove to be useful, peasants incorporate them into the dynamics of local seed systems, or what is now called informal seed systems (Dyer and Taylor 2008: 470, Louwaars et al. 2013: 43-45). As the case of Manuel exemplifies, this means the reproduction and improvement of seeds using local knowledge through the agricultural cycle, and then their exchange within the social norms of communities (Badstue et al 2007: 1580, Coomes et al. 2015: 42, Sotelo 2017: 2). "Informal seed systems are still the prevailing source of seed in developing countries," write Badstue et al. (2007: 1580). According to the FAO, "informal seed systems remain a key element in the maintenance of crop diversity on farm and can account for up to 90 percent of seed movement" in most developing countries (2010: 40). The production of maize in Mexico exemplifies the importance of informal seed systems, and native seeds as a key part of them, for agriculture. According to Perales and Golicher, "more than 2.5 million Mexican farmers plant about 8 million hectares annually with over $75 \%$ of the seed that is sown saved by farmers from their previous harvest. Landraces [native seeds] comprise at least one-half of the seed planted each year in Mexico" (2014: 2).

This dynamic is the complete inverse of the logic of formal seed systems. Those are industrial systems that depend on public or private institutions and scientific knowledge for the production and diffusion of genetic material (hybrid, improved, or 
transgenic seeds). Formal seed systems rely on institutional certifications, formal markets, and, increasingly, on patents and intellectual property rights. Therefore, seeds and germplasm are considered to be commodities (Louwaars et al. 2013: 45-46, Réseau 2011: 8).

Nevertheless, although contrasting in nature, traditional and formal seed systems have actually historically complemented each other (Louwaars et al. 2013). Formal seed systems incorporate genetic material that has been produced and preserved by peasant communities, and use it for improving or creating new varieties. In turn, peasants use and reproduce improved seeds, and many times end up incorporating them into their own seed systems (see Figures 7 and 8). Communities' biodiversity reflects this symbiosis between formal and informal seed systems (Badstue et al. 2007: 1580, Dyer and Taylor 2008: 470, 474, Perales 2016, Réseau 2011: 8-9). The concept of integrated seed systems refers to this complementarity (Bellon et al. 2011, Louwaars et al. 2013: 48-50). For instance, in some mestizo communities in the region of study, what peasants now call a native maize could actually be the result of a combination of local and hybrid maize that occurred years ago — what is formally called a creolized seed (Perales 2016: 272). Alternatively, as in the case of Manuel mentioned above, local native maize might be mixed with native maize brought from other regions of Mexico or other parts of the world. Native seeds are far from always "pure" or "original," and local biodiversity is the outcome of this evolutionary process (Dyer and Taylor 2008, Perales 2016).

The distribution and structure of seed diversity and the correlation between native and commercial seeds in a specific community or region are determined by several 
factors, with environment (mainly altitude and geographic location) and irrigation being the major influences (Perales 2016: 273). However, other socio-economic factors (farm size, production for the market, education, access to credit and information, participation in the off-farm labor market) and cultural factors (ethnicity, values, beliefs, social networks) are also relevant in shaping biodiversity (Brush and Perales 2007: 211, 219220). As Brush and Perales remark in their study on maize diversity in Chiapas, seed population structure "is likely to have a cultural basis in that indigenous communities experience centripetal cultural pressure that is absent in mestizo communities" (2007: 220, see also Wolf 1959). In other words, indigenous communities tend to be more closed than mestizo communities - the history of domination of indigenous communities by non-indigenous people is critical in this cultural development (Brush and Perales 2007: 220). Hence, the predominance of native seeds, the use of traditional methods for the reproduction and improvement of germplasm, and the orientation of agricultural production for subsistence are more salient in indigenous than in mestizo communities (Badstue et al. 2007, 2006, Brush and Perales 2007, Sotelo 2017).

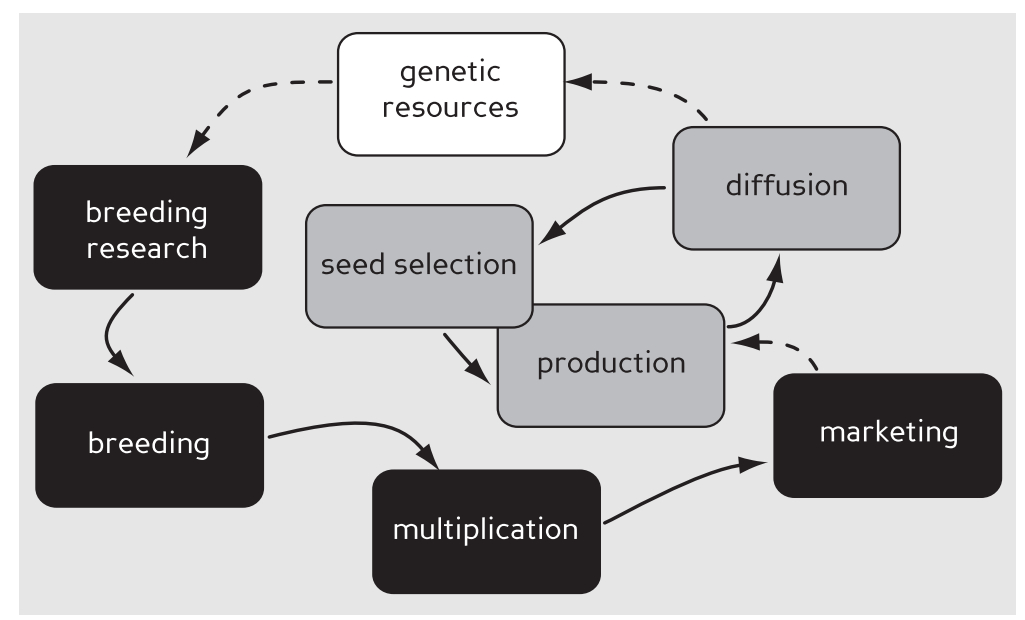

Figure 7. Integrated Seed Systems: formal (black color) and informal (grey color) seed systems and their relationships (reprinted from Réseau 2011). 


\begin{tabular}{|c|c|c|c|}
\hline \multirow{2}{*}{\multicolumn{2}{|c|}{ Transactions }} & \multicolumn{2}{|c|}{ Seeds } \\
\hline & & Formal & Informal (or de facto) \\
\hline \multirow[t]{2}{*}{ Markets } & Formal & $\begin{array}{l}\text { A Certified, improved or } \\
\text { purified seed sold in an } \\
\text { input supply shop, via } \\
\text { extension programmes, or } \\
\text { licensed distributors. } \\
\text { The sale is often } \\
\text { regulated by the government. }\end{array}$ & $\begin{array}{l}\text { D Sale of recycled farm-saved seeds } \\
\text { or landraces in a setting where sale } \\
\text { of informal seed is explicitly permitted, } \\
\text { or alternatively where this is not } \\
\text { permitted, but prohibitions on } \\
\text { non-certified seed sale or other } \\
\text { deterring regulations are not enforced } \\
\text { and the public widely recognizes this. }\end{array}$ \\
\hline & Informal & $\begin{array}{l}\text { B Sale of certified improved } \\
\text { seed via non-regulated } \\
\text { marketing outlets. One } \\
\text { example might be of a small } \\
\text { market trader who buys a } \\
\text { large bulk sack of seeds } \\
\text { from an input supply shop } \\
\text { and divides it into smaller } \\
\text { packages. }\end{array}$ & $\begin{array}{l}\text { E Sale of non-certified seed in } \\
\text { transactions where seed is not } \\
\text { explicitly recognized as the product. } \\
\text { Formal distinction of seed from grain } \\
\text { may not be explicit. Sale takes place } \\
\text { in a forum that is not recognized } \\
\text { under national law or widely } \\
\text { acknowledged by the public to be } \\
\text { a source of seed. }\end{array}$ \\
\hline $\begin{array}{l}\text { Non- } \\
\text { market } \\
\text { exchanges }\end{array}$ & & $\begin{array}{l}\text { C Theoretically, these } \\
\text { exchanges would happen } \\
\text { very infrequently because the } \\
\text { majority of 'formal' seed is } \\
\text { produced with the specific } \\
\text { purpose of marketing. } \\
\text { An exception might be } \\
\text { when formally produced } \\
\text { seed is gifted by political } \\
\text { candidates. }\end{array}$ & $\begin{array}{l}\text { F Acquisition of seed through } \\
\text { sources not involving market } \\
\text { exchange. This includes saving one's } \\
\text { own seed, receiving it as a gift from } \\
\text { other farmers in the community or } \\
\text { friends/family, or receiving it as a gift } \\
\text { from an NGO or other organization. }\end{array}$ \\
\hline
\end{tabular}

Figure 8. Types of Exchanges and Seed Types (reprinted from Dalton et al. 2010: 21).

\section{Threats to Seeds}

However, this complementary relationship between formal and informal seed systems is changing substantially under neoliberalism. The imposition of patents and intellectual property rights over germplasm, the aggressive implementation of international treaties on plant genetic resources and seed certification laws, and the eradication of exemption rights for peasants and researchers imply a de facto privatization of seed systems (see Chapter 1).

Perhaps the elimination of exemption rights is the clearest indicator of the degree 
of this privatization. Exemption rights refer to the rights of peasants and researchers to use, save, reproduce, improve, and exchange protected seeds (De Schutter 2009: 7). These rights illustrate the significance of the historical relationship between formal and informal systems. Exemption rights ruled international seed systems until 1991, when the International Union for the Protection of New Varieties (UPOV, which grants breeders at least 20 years of rights over novel, distinct, uniform and stable plant varieties) eliminated them altogether (Golay 2016: 14). "If previous versions of UPOV [1961, 1972, 1978] already prohibited peasants from selling protected seeds," writes Golay, "the 1991 Act also prohibits peasants from exchanging these seeds, and peasants can save and re-use protected seeds only if their government has enacted an optional exception to the 1991 Act” (2016: 14). However, according to the U.S. NGO Food \& Water Watch, although such an exception is a legal possibility, most countries do not pursue it. Influencing this outcome is the intense lobbying campaign that the U.S. State Department has been developing to promote agricultural biotechnology policies worldwide (2013).

According to De Schutter, the former UN Special Rapporteur on the Right to Food, the rise of agricultural biotechnology and the commercialization of transgenic crops since 1994 have only exacerbated these trends. "Farmers cultivating patented seeds do not have any rights over the seeds they plant," comments De Schutter. "They are considered to be licensees of a patented product, and they frequently are requested to sign agreements not to save, resow or exchange the seeds which they buy from patent-holders. Patents are the most far-reaching form of protection that can be granted" (2009: 6). Reinforcing this idea, the Réseau Semences Paysannes (Peasant Seeds Network) states 
that intellectual property creates a protected monopoly over plant reproduction because it "prevents farmers from freely gathering the seeds of plants cultivated in their fields, to reproduce them the following year" (2011: 31). This process of privatization goes even further, comments Perales, because:

Coming from the U.S. and Europe, there is a growing pressure over other countries not only to adopt the system of intellectual property rights over seeds, but also to model whole national seed systems to their own. The U.S. and Europe are pressuring other countries to adopt the seeds they work with. This is a total privatization because they eliminated the exemption rights of farmers and researchers over those seeds...intellectual property has reached the limit, it is extreme and almost criminal because it puts the food system at risk. Eventually, it might prevent the exchange of seeds. ${ }^{31}$

Furthermore, these processes of regulation and privatization of seed systems have been advancing with almost no information reaching peasant communities. "Now we have all these laws that have for years been preparing the way for the privatization of seeds; for instance, the [Mexican] laws on seed certification and GMOs," says Mariano, a DESMI staff member. "However, there has never been enough information coming from the government about these regulatory measures; they just appeared overnight. Very few people in these communities know anything about the existence of these laws, and nobody has an idea what they are about. There is not sufficient information to allow these communities to make decisions. This is a very worrying situation because seeds are the subsistence base of these communities; therefore, their privatization directly threatens 
their survival." 32

I ask Jxun, the Zapatista Tseltal man from Tenejapa, to tell me something about how indigenous communities perceive the idea of the potential privatization of seeds. After reflecting for a while, he says:

So I saw and still see my mother threshing the maize and selecting the seeds that will be saved for the next [agricultural] cycle. When the moment for sowing has arrived, when the soil is ready to receive the seeds, my mother places the seeds in a basket and blows water over them until they are humid. My mother says that through this act, blowing water over the seeds, she is giving them her ch'ulel [spirit and soul]. This means that she is transferring her own soul and spirit to the seeds. She is giving life to those seeds...This union between human and seed is sacred, is something that must be respected, is a right to life, a principle of our own existence in freedom. That is why it is unacceptable that corporations seek to appropriate the seeds of the world...to privatize seeds is to prohibit and annihilate any form of life in the universe. It means sowing hunger, subjecting humanity to the power of corporations. This is avarice by the corporations that want to expropriate from humanity that principle of freedom, and that is unacceptable. ${ }^{33}$

Before exploring more in depth how peasants perceive the relationship between industrial and native seed systems, it is valuable to contextualize the development of industrial seeds as part of the Green Revolution project. This analysis will provide a more nuanced picture of the multiple impacts that industrial seed systems have in these communities. As I will explain, the privatization of seeds and germplasm is only one 
aspect of the contested relationship between industrial and informal seed systems.

\section{Industrial Agriculture and Seeds}

\section{The Green Revolution in Context: Industrial Seeds and Food Sovereignty}

The articulation of industrial seed systems at global scale is an essential element of the neoliberal agri-food system. Although there is not a definitive consensus about the distinct characteristics or the timeline of what is called the neoliberal agri-food system, I argue that its roots can be traced to the Green Revolution project that began in the early 1960s.

According to Gollin et al., the best way to understand the Green Revolution, "arguably the most important episode of agricultural innovation in modern history," is "as an increase in the rate of growth of agricultural productivity, based on the application of modern crop breeding techniques to the agricultural challenges of the developing world," which included rural poverty and agrarian unrest (2016: 2, 7). Under Green Revolution policies, thousands of high-yielding crop varieties (HYVs) have been developed and adapted to different environments in the tropical and semi-tropical regions of the world (2016: 9).

The first two crops that were successfully bred and released to farmers in Latin America and Asia were wheat in Mexico in 1961 and rice in the Philippines in 1965 (Gollin et al. 2016: 7). That was just the beginning, however: by 2000 more than 8,000 HYVs of 10 staple crops (rice, wheat, maize, sorghum, millet, barley, cassava, dry beans, groundnuts, potatoes) had been released by more than 400 public breeding programs and seed boards in over 100 countries (Evenson and Gollin 2003: 758). Gollin et al. calculate 
that by 2000 , the adoption rate of HYV crops - the harvested area planted to HYVs as a portion of the total harvested area for the crop - in the developing world as a whole (a total of 84 countries) had reached 58 percent. ${ }^{34}$ Today, these 10 food crops account for about 60 percent of the total harvested area in developing countries; the remaining 40 percent is mostly cash crops such as sugar and cotton, and crops used for fodder (Gollin et al. 2016: 13).

Contrary to the notion that the Green Revolution was limited to the 1960s and 1970s, the contributions of HYVs to growth in global crop yields were actually much higher for the period between 1980 and 2000 (the "late Green Revolution") than in the preceding two decades (the "early Green Revolution"). Growth in crop yields under the Green Revolution can be broken down into the contributions of HYVs themselves and the contributions of all other inputs: mechanization, irrigation, agrochemicals (fertilizers, herbicides, pesticides), and specialized labor. Together, these inputs are called agricultural technological packages (Evenson and Gollin 2003: 760).

During the early period between 1960 and 1980, HYVs accounted for only 21 percent of the growth in yields and about 17 percent of production growth for all developing countries; area expansion accounted for about 20 percent of the increase in production, and the rest came from the intensification of input use. In contrast, during the late Green Revolution, HYVs accounted for almost 50 percent of yield growth and 40 percent of production growth, while the area under food crop cultivation remained flat overall. Furthermore, during this second period, yield growth accounted for 86 percent of the increases in food production in developing countries. According to Evenson and 
Gollin, "this indicates that in the late Green Revolution period, production gains were more dependent on MVs [Modern Varieties, i.e., HYVs] than in the early period, and that MVs' contributions were greater in the late period." They add that "[a]lthough input use intensified in the late Green Revolution period, productivity gains from MVs allowed food production to increase dramatically with only modest increases in area planted to food crops - and with relatively slow growth in the use of inputs such as fertilizer and irrigation" (2003: 760).

Although there are not yet comprehensive data for the years since 2000, this trend is expected to have continued. Some elements that could indicate this trajectory are the development and adoption of new HYVs (including GMOs and their technological packages), the neoliberal dismantling of federal policies supporting peasant agriculture, and the articulation of regional industrial agriculture systems under "free trade" agreements such as NAFTA. As Evenson and Gollin point out, "the productivity data suggest that the Green Revolution is best understood not as a one-time jump in production, occurring in the late 1960s, but rather as a long-term increase in the trend growth rate of productivity. This was because successive generations of MVs were developed, each contributing gains over previous generations" (2003: 760).

How do Green Revolution policies look from the perspective of the Mexican government? Jorge Kondo, the director of Sagarpa (Mexican Ministry of Agriculture, Livestock, Rural Development, Fisheries and Food) between 2011 and 2015, offers a good example. In an interview conducted by Camou Guerrero in 2014 for the documentary Sunú-"maize" in Raramuri, an indigenous language from northwestern 
Mexico—Kondo addresses the perseverance of native seed systems among subsistence peasant communities. "What good is a poor farmer who is condemned to plant those native seeds?" Kondo rhetorically asks. "We're better off putting that seed away, as we could later discover certain properties we are unaware of right now and give those farmers hybrid maize varieties that adapt to the region and yield ten tons." He develops his argument further:

We have two main challenges: to increase production in order to reduce our importation of American corn, and reduce poverty, mainly food poverty. We are talking about seven million people, most of them in the countryside, who are not eating enough. How can we resolve this problem when Mexico is a modern country that depends little on peasant agriculture? However, we have the poorest people living in the countryside and that is something that we cannot ignore and have to resolve. We need to implement programs targeting food insufficiency...We already did an experiment in Quintana Roo. We distributed high-quality protean maize [an industrial improved variety] in a small community located in the middle of the jungle. It worked well. I would also introduce improved beans with added protein and vitamins...we can resolve these problems, but we need to introduce that kind of seeds [HYV] (Camou Guerrero 2015). Latter in the same interview, Camou Guerrero asked Kondo about the potential presence of transgenic corn in Mexico, one of the most controversial issues in the country since 2001, when a study from the Department of Environmental Science at the University of California, Berkley, detected transgenic DNA in native maize in the Sierra 
Juárez of Oaxaca-Chiapas's neighboring state, and one of the areas with the greatest diversity of native maize in the country ${ }^{35}$ (Piñeyro-Nelson et al. 2009, Quist and Chapela 2001). Without hesitating, Kondo comments: "Let's not fool ourselves. We're importing GM corn. The 11 million tons we import are all genetically modified" (Camou Guerrero 2015).

By 2016, Mexico's annual imports of U.S. corn had grown to 13.8 million tons. Nearly all of this - 12.7 million tons - is yellow corn, which is largely used for livestock feed. Mexico is essentially self-sufficient in non-GM white maize, which is mostly produced for human consumption (Semple 2017). After more than twenty years of NAFTA, Mexico has consolidated itself as the second largest foreign market for U.S. corn (23 percent), behind only Japan (26 percent) (U.S. Grains Council 2017). Considering that a little over 90 percent of all the corn produced in the U.S. is genetically modified (USDA 2017), and that Mexico's imports of this crop are constantly rising, it seems clear that the country will continue importing GM corn despite the increasing opposition from civil society to GMOs.

This development has had important implications for Mexican society. Despite the fact that commercial production of transgenic corn has been banned in Mexico since 2013 and imported U.S. GM corn is supposed to be limited to animal consumption and industrial use, a recent study by the Universidad Nacional Autónoma de México (UNAM) found that "transgenic sequences were present in overall $82 \%$ of assayed food categories [most commercial foods in which corn is the main ingredient]; while the most widely consumed form of maize in Mexico, tortillas [commercial tortillas made with 
hybrid white corn], had recombinant sequences in $90.4 \%$ of the samples...Additionally, glyphosate was detected in approximately $27.7 \%$ of the samples rendered positive for transgenic events tolerant to this herbicide" (González-Ortega et al. 2017: 1146). These results are alarming because of the very widespread presence of transgenic corn markers in food in a country in which transgenic corn for human consumption is not allowed. The study also found the presence, although in much lower frequency, of transgenic markers in artisanal tortillas made with native maize instead of hybrid corn. Moreover, 50 percent of the foods labeled as "GMO-free" tested positive for the presence of transgenic maizespecific markers. "These findings suggest," González-Ortega et al. write, "that protocols aimed to assure segregation between transgenic and conventional maize are not $100 \%$ effective" (2017: 1159).

Taking into account these data, the declarations by Kondo are significant. At least four questions deserve to be asked in response. First, what might be the impacts on native maize biodiversity if the government continues (a) to promote the adoption of hybrid maize seeds, even among subsistence farmers; and (b) to increase the imports of transgenic corn? This question is particularly relevant because Mexico is the global center of origin and diversity of maize, and the evolution of agro-biodiversity largely relies on peasant agriculture and the reproduction of native seed systems (Dyer et al. 2014: 14094, González-Ortega et al. 2017: 1147, Mercer et al. 2012: 495). Second, to what extent can these federal programs targeting food insecurity be successful if they disregard the cultural and spiritual meanings that peasant communities assign to their native seed systems? Third, how do these federal policies on seeds and food security 
influence the growing contention between informal and industrial seed systemsspecifically, the contradiction between seeds as commons and seeds as commodities? Finally, what role has civil society—particularly the food sovereignty and anti-GMO initiatives that have emerged in the context of NAFTA — played in the development of federal agendas on seeds?

These questions lie at the heart of two of the most controversial contemporary debates in Mexico: the liberalization of the national maize market under NAFTA's agriculture chapter, and the introduction of GMOs. Both issues are directly related to seeds and Green Revolution policies. This analysis cannot be complete, however, without taking into consideration some of the main responses to these developments that have come from civil society.

\section{The Green Revolution's Countermovements: Anti-GMOs and Seed Sovereignty}

The Mexican civil society initiatives that best synthetize these debates are the Zapatista initiative Semillas Madre en Resistencia desde las Tierras de Chiapas (Mother Seeds in Resistance from the Lands of Chiapas), the national campaign Sin Maiz No Hay Pais (Without Maize There is No Country), and the Mayan coalition MA OGM (NO GMOs) in the Yucatan Peninsula. It is important to briefly discuss these campaigns here to contextualize the local agenda on seed sovereignty that is evolving in the area of study.

The EZLN was among the first voices in the country against GM corn. In 2002, one year after GM corn DNA was found in native maize in the neighboring state of Oaxaca, the EZLN launched Semillas Madre en Resistencia (Sme' Tzu'nubil Stzi'kel Vocol, in Tsotsil). This campaign emerged in opposition to the potential contamination of 
Mayan maize due to the presence of transgenic corn in the region. In collaboration with the activist grassroots organization Schools for Chiapas, the EZLN carried out about 1,100 tests to detect GM corn markers in several varieties of native maize coming from the five regions of the Zapatista territory. After corroborating that local maize was "still natural" and "not sick from the greed of corporations," the EZLN declared a Zapatista GMO-free zone and, in an attempt to raise a global voice against GM corn, donated more than twenty varieties of native maize to different communities across the world (Brandt 2014, Brown 2013, OCA 2004).

Since then, Semillas Madre en Resistencia has engaged in the diffusion of information about GMOs among peasant communities in Chiapas, including nonZapatista communities. It also continues to promote the reproduction of Zapatista maize in parcels around the world; today it is possible to buy via internet "GMO-free Zapatista seed corn" (about 60 seeds for U.S. \$7) that Zapatista farming families donate to Schools for Chiapas to support the project (Brandt 2014, Brown 2013, Schools for Chiapas 2017). According to Peter Brown, founder and director of Schools for Chiapas, what began in 2002 as a small seed bank in the Caracol of Oventic "has been massively eclipsed by a worldwide living seed bank of Zapatista corn. This Zapatista 'seed bank' includes scientifically pure grow-outs at undisclosed locations, peasant plantings in Africa, and solidarity gardens in major cities. In fact, this living entity is now growing in dozens of countries and on every continent of the planet except Antarctica" (2013: 175).

As has been characteristic of the Zapatista movement since its origins, local campaigns are easily escalated to national and global spaces through the rich network of 
solidarity organizations that collaborate with the EZLN (Barmeyer 2009). The Zapatista anti-GMO campaign was no exception. Soon after the launching of Semillas Madre en Resistencia, different peasant and indigenous communities across the country were organizing their own resistance campaigns against GMOs (GRAIN 2013).

Many of those anti-GMO initiatives converged in the much larger national campaign Sin Maíz No Hay País, a food sovereignty initiative encompassing more than 300 peasant and civil society organizations. It was launched in June 2007, just a few months before the final liberalization of the maize market under NAFTA's agriculture chapter. While the liberalization of maize seed imports took place almost imperceptibly in 1994, the gradual elimination of protective quotas limiting the importation of corn as grain was a long-term process lasting until 2008 (Dyer and Yúnez-Naudez 2003). The agenda of Sin Maiz No Hay País focused on five demands: (1) the exclusion of maize and beans from NAFTA; (2) the banning of transgenic corn in Mexico and the implementation of federal programs to protect native maize diversity; (3) the recognition of the right to food ${ }^{36}$ in federal legislation; (4) the implementation of policies preventing the formation of monopolies in the agriculture sector; and (5) the promotion of native maize and the recognition of the cultural relevance that this crop has for Mexican peoples (Sin Maíz No Hay País 2008).

Although the campaign has not achieved its main goal - the exclusion of maize and beans from NAFTA - it has been much more successful in articulating a national anti-GMO campaign linked to the protection of native maize diversity. Its main achievement occurred in 2013, when the federal government reestablished the 
moratorium on the commercial planting of GM $\operatorname{corn}^{37}$ (Alire Garcia 2017, Enciso 2015, Lesperance 2017).

Simultaneous to the battle against transgenic corn, $M A O G M$ launched its own campaign against Monsanto and the cultivation of transgenic soy in 2011. MA OGM is a coalition integrating virtually all of the beekeepers - about 15,000 families, most of them Mayan indigenous - from the Yucatan Peninsula, one of the world's foremost honey producing areas (La Jornada del Campo 2015b, Tamariz 2013, Villanueva-Gutiérrez et al. 2014). The coalition was formed after the European Union (EU) pronounced that same year a "transgenic honey" ruling declaring that all imported honey had to be subjected to examination to prevent the importation of honey contaminated with GM pollen, which, the EU declared, is "not apt for human consumption." This ruling had strong effects on beekeepers in the region because the EU was buying about 90 percent of the local production (Tamariz 2013: 10-11).

In order to protect local apiculture, $M A O G M$, together with the three state governments located in the Peninsula (Yucatan, Campeche, and Quintana Roo), demanded the banning of GM crops in the area, and particularly the suspension of the 60,000 hectares of Roundup Ready (RR) soybean that Monsanto was cultivating in the region as a pilot program $^{38}$ (Tamariz 2013: 11-14). In 2014, a multi-institutional study carried out in the state of Campeche confirmed the presence of GM soybean pollen in local honey (Villanueva-Gutiérrez et al. 2014: 1). Finally, after years of legal disputes between Monsanto and the association of beekeepers, a federal court ordered in 2015 a halt to the cultivation of transgenic soy in Yucatan and Campeche (Lesperance 2017). 
The court also ruled that any new application for the planting of transgenic soy close to indigenous territories first must be presented to indigenous communities for consultation (Pietrowsli 2016). Although this ruling was originally focused on the states of Yucatan and Merida, in 2016 a federal court also suspended the production of transgenic soy in Chiapas, where 50 percent of the 14,000 hectares producing soy were planted in Monsanto's RR soybean (Bautista 2017).

What began as three separate campaigns with specific actors and goals had become a national struggle against transnational seed corporations and GMOs. This countermovement has so far achieved only a partial victory. Certainly, transnational corporations_-essentially Monsanto_-face strong opposition from both civil society and federal courts to the commercial planting of GMO crops in Mexican territory. However, this achievement must be weighed against the increasing importation of U.S. GM corn as grain and other transgenic crops. To the controversial transgenic corn and soybeans must be added other GM crops that are imported or produced in Mexico, mainly in the industrial states of the north, such as cotton and canola (COFEPRIS 2015). This analysis is particularly relevant to food sovereignty issues. As the study by González-Ortega et al. reveals, despite strong civil society opposition to GMOs, transgenic corn is still being massively consumed on a daily basis by millions of Mexican people (2017). Furthermore, this is happening almost secretively and with the complicity or tolerance of the government, because there are no regulations requiring corporations to label foods containing GMOs. These developments reflect the increasing polarization of interests that prevails in the relationship between industrial and native seed systems. 


\section{Beyond Industrial Seeds: Agrochemicals, Labor, and Environmental}

\section{Deterioration}

How have these Green Revolution dynamics impacted the peasant communities analyzed in this study? This question is important in a regional context in which between 90 and 95 percent of all seeds planted by peasants still originate from within the community. In other words, the adoption of HYVs in these communities is practically nonexistent. The region is also characterized by a lack of fertile soils suitable for intensive agriculture or the use of mechanization and irrigation systems. In fact, these elements have reinforced subsistence agricultural practices, including the conservation of native seeds (Brush and Perales 2007, see Badstue et al. 2006 and 2007 for a similar analysis in Oaxaca). "These indigenous communities were very disadvantaged during the agrarian reform because most of the lands they received were of very poor quality, with topographic conditions that make impossible the mechanization of production," comments Mariano, a staff member of DESMI. "It is also true that these same environmental conditions have favored the preservation of native seeds, and with them the subsistence of these communities," he adds. ${ }^{39}$

Although Green Revolution policies have not yet managed to introduce HYVs in this region — despite the many government programs aiming to do so- they nonetheless have a strong impact on these peasant communities. Interestingly, what peasants adopted from the multiple technological packages that the government had delivered in previous years were the fertilizers and herbicides that came along with the HYVs. "In the 1970s, as part of the federal Plan Puebla project, the government distributed the Green 
Revolution package. It contained seeds [HYVs], herbicides, and fertilizers," comments Hugo Perales:

What happened in this region? Peasants adopted everything except the seeds. And this was not because they were against commercial seeds. Peasants tried the seeds and discovered that they were no better than their own seeds, almost the same. Why would peasants adopt external seeds that they have to buy and depend on if they have their own seeds? At these altitudes, commercial seeds do not work better than native seeds. It is different in lower altitudes where hybrids work very well, but here in Los Altos, native seeds work better than commercial seeds. This is a pragmatic decision. Peasants have adopted the agrochemicals but not the seeds. ${ }^{40}$

As I already mentioned in a previous chapter, nowadays the use of agrochemicals is prevalent across Chiapas - in indigenous and mestizo communities alike, including both Zapatista and non-Zapatista villages. In their study analyzing maize production in the Los Altos region of Chiapas, Eakin et al. found that among subsistence households, about 94.8 percent use fertilizers, 78.7 percent use herbicides, and 36.9 percent use insecticides. In the case of households producing a surplus for the market ('seller' households), ${ }^{41}$ the percentages increase to 99.6 for fertilizers, 93.3 for herbicides, and 71.9 for insecticide (2014a: 140).

\section{The Free Family Labor Dilemma}

The introduction of agrochemicals has had several impacts on these communities. The most evident of them is a change in the ways peasants work the land (McCune et al. 
2012, Ríos González 2013). José, a Zapatista Tseltal man in his sixties from Tenejapa, reflects on this: "the way we used to work our milpas has changed. More than the way in which we take care of seeds, what has changed is how we clean and prepare the land. Before, all people in my community, and my own family, we used to clean the land using our machetes and other tools. Before, we are talking about the 1970s. It was when the government first brought a program and gave us fertilizers and some chemicals for killing the weeds and preparing the land for cultivation." After reflecting for a few minutes, he adds: "to date we continue using chemicals to work the land. We still use our machetes, but also those chemicals. This has modified the production of maize, the production of beans. Some times people would say that 'the milpa gives more' when they put on the chemicals, other times that 'the land is not producing anymore' if they do not feed the land with chemicals. So, we see how people are increasingly dependent on the use of chemicals for working the land." ${ }^{42}$

In a different context—during a DESMI seed sovereignty workshop in San Andrés-Joel, a non-Zapatista Tsotsil man in his forties, addresses the audience: "Our milpas are very sad because we have contaminated them with chemicals. Of all the people here [125 representatives from the nine regions of the parish], only three of us don't use chemicals." Then, he rhetorically asks: "Why are we doing this, brothers?"43 "Because it is easier," answers Marcelino, a priest from a Tseltal community in Cancuc who promotes organic methods of cultivation in the region, when I ask him the same question. "Instead of using your hands and the machete, you can kill the weeds and the animals just spraying the chemical. It is a lot less work and you save a lot of time. 
With the chemicals you resolve things faster. Producing organic requires a lot of work, and many people don't want to do it, particularly now that many of them work outside of their lands." ${ }^{44}$ Sebastian, the former director of DESMI, concurs: "the use of agrochemicals has changed how peasants work the land. Chemicals save time and allow peasants to work alone because each person can have their own spray pump. Before, you had the whole family and some neighbors clearing the weeds, preparing the land. Now, you can do it yourself, and that is a huge difference." ${ }^{45}$ Jimena, a non-Zapatista mestiza woman in her late forties from Venustiano Carranza, suggests that the use of agrochemicals reduces the dependence on labor. "My husband uses the chemicals in the milpa because it is less work and we do not have enough money for hiring jornaleros. My children now have their own milpas and cannot help us all the time. ${ }^{, 46}$ Juanita, a mestiza woman in her twenties from Teopisca, says: "everyone here uses the matazacate [herbicide] in the milpa. Here in the traspatio [patio garden] we try not to use it all the time. We try to produce cleanly. We only use it when we have other things to do-for example, preparing a celebration, or something to do outside the community. If we don't have time, we just use the chemical and it is done., ${ }^{47}$

In addition to saving time, the use of agrochemicals also partially resolves the increasing scarcity of free family labor, which has historically been a central axis of the milpa system (Nations and Nigh 1980, Rus 2012, Wasserstrom 1977). Although almost all peasant households in the region continue to work the milpa as a food security strategy, the production of maize does not resolve their need for cash income. Peasants have to assure themselves at least a minimal amount of cash to allow them to buy maize 
during the meses flacos and satisfy other family needs. Peasants also need cash to buy agrochemicals or hire jornaleros to complement the work in the milpa. According to Eakin et al., as much as 72.1 percent of subsistence households and 42.5 percent of seller households in Chiapas report that their primary income is from a non-farm source: wage labor, self-employment, pensions, government transfers, or remittances. The use of family labor and hired jornaleros also differs between subsistence and "seller" households: in the former, the average number of family members working on the farm is 2.6, while in the latter it is 2.0. The use of hired jornaleros is also common in both types of households, although the percentages considerably differ among them: while only about 40 percent of subsistence households rely on jornaleros, almost 70 percent of “seller” households do so (2014: 143).

Aside from government transfers and remittances as income sources, these data reflect two national trends: the decreasing number of adults employed in the agricultural sector, and the increasing incorporation of women into the labor market. In the case of Chiapas, while in 1990 the agriculture sector represented the main source of income for 60 percent of adults, by 2010 this percentage had decreased to 40 percent. In the opposite direction, the participation of women in the labor market increased from 11 to 24 percent during the same period (Eakin et al. 2015: 87). According to Eakin et al., the average number of income earners in subsistence households is about 2.6, in contrast to 1.9 for 'seller' households (2014: 143).

These trends accurately describe both the Zapatista and non-Zapatista communities in this study. At the time of my fieldwork, most of the families in this study 
had at least one source of cash coming from the labor market. In most of these communities both men and women contribute to household expenses. For instance, in the mestizo communities of Teopisca, and the Tseltal and Tsotsil communities of Cancuc, Tenejapa, and San Andrés, many women produce tortillas, tostadas, atole, and tamales for sale in the plazas and markets (women earn a gross income of about 100 pesos per day, or U.S. \$5; from this amount it is necessary to subtract expenses such as maize, firewood, and transportation). In Venustiano Carranza, most young and middle-age mestiza women produce on commission hand-made embroidery for a maquila that assembles blouses and t-shirts in San Cristóbal de las Casas, earning between U.S. \$1 and $\$ 3$ for a piece requiring two to three days work. These women work in their communities and the maquila provides them all the material needed. Most men in these communities also work, depending on the season, between two and five days per week in alternative jobs as masons, jornaleros, taxi drivers, or food sellers. Daily wages are, on average, between U.S. $\$ 3$ and $\$ 5 .{ }^{48}$ Despite these commonalities between indigenous and mestizo, and Zapatista and non-Zapatista communities, there is also a substantial difference between them. In line with EZLN resistance policies, Zapatista communities refuse to receive any kind of government subsidy or service programs (see Chapter 3). In contrast, almost all of the non-Zapatista households in this study are enrolled at least in one governmental program.

Reinforcing the free family labor dilemma, government programs such as Prospera increase household income but indirectly promote the depeasantization of these families by conditioning the delivery of cash to mothers upon sending their children to 
school. In Chiapas, more than 700,000 households — including practically all households in the non-Zapatista communities in this study—are now beneficiaries of Prospera, and each child attending school—instead of working in the milpa —represents a monthly income of between 175 and 1,120 Mexican pesos (U.S. \$10 to \$60), depending on the student's gender and year in school. ${ }^{49}$ Prospera also delivers a monthly food support payment of 470 pesos (U.S. \$25) to all beneficiary households (Gobierno de Mexico 2017). Considering the extreme poverty of many peasant families in Chiapas, particularly in indigenous communities, these cash supports are quite significant for such households.

To date, the free family labor dilemma is partially resolved across the region through a combination of four strategies: hiring jornaleros, reducing the amount of land under cultivation, implementing agricultural intensification strategies, and buying food in the market to supplement subsistence production. As I discussed in early sections, under adverse conditions for reproducing peasant agriculture, households will tend to reduce the costs of the milpa to the minimum possible. The introduction of livestock, the nearmono-cultivation of maize and beans, the intensification of the milpa-increasing the cropping frequency by reducing the ratio of the fallow to the cultivation periods - and the increasing use of agrochemicals for sustaining this intensification, are some of the most common responses to these conditions (Busch and Geohegan 2010, Ochoa-Gaona and González-Espinosa 1999, Radel et al. 2012, Schmook 2010).

Unexpected Consequences: Environmental, Health, and Dietary Deterioration Although the use of agrochemicals has brought some benefits to these communities, particularly the reduction of labor required to sustain the milpa, it is 
apparent that the costs of this strategy have substantially surpassed those benefits (Ríos González 2013, Tinoco-Ojanguren and Halperin 2010). The widespread dependence on agrochemicals and their pervasive impacts on the environment and health of these communities are some of the main concerns that peasants disclosed to me during my fieldwork.

"The main impact of using agrochemicals is that the soil is impoverished," comments Jtin, a Zapatista Tseltal man in his thirties from Tenejapa. "When you clean the land with the machete, a small layer of weeds remains in the soil. With the chemicals, however, what happens is that when you burn the weeds, everything disappears from the soil, you kill everything, and the soil becomes uncovered [se queda pelón]. Then, when it rains, the soil is eroded, and that makes the land much poorer." ${ }^{, 50}$ Besides the deterioration of the land, peasants also associate the use of agrochemicals with the pollution of water sources. "When chemicals are used, the rivers, the veins of the earth, the water, all get polluted; every source of water becomes poisoned," says Rosa, a nonZapatista Ch'ol woman from Tumbalá. "The water that we drink in our communities, the rivers in which we take showers and wash our clothes, all that water is poisoned because of the chemicals."

Indeed, these perceptions might be accurate. Monsanto's glyphosate-based herbicide is currently under intense debate worldwide due to concerns about its potential harmful effects on the environment and human health. Glyphosate - the world's most widely used weedkiller, first introduced in 1974, which alone made up a third of Monsanto's total corporate sales in 2015-is one of the three most used agrochemicals in 
Chiapas; the other two are the complementary paraquat-based herbicide and the 24P fertilizer (Kelland 2017, McCune et al. 2012: 498, Silva et al. 2017, The Guardian 2016). In addition to the pollution of soils and water bodies, several studies-including those from the UN World Health Organization's Cancer Agency—have also associated the use of glyphosate with cancer and endocrine disruption in humans and acute and chronic toxicity to aquatic species (IARC 2017, Silva et al. 2017).

Although glyphosate's associated risks for humans and wildlife are still under scrutiny — mainly because Monsanto has invested millions of dollars in financing contrary research — evidence about its damaging effects has been accumulating in recent years (Kelland 2017, The Guardian 2016). The sharp increase in the worldwide use of this herbicide has become highly controversial since 1996, when glyphosate-tolerant GM crops were first introduced in the market by Monsanto. According to Benbrook, the global use of glyphosate has risen almost 15-fold since 1996. In the case of the U.S., twothirds of the total volume of glyphosate applied from 1974 to 2014 has been sprayed in just the last ten years, and the U.S. alone accounts for 19 percent of the estimated global use of glyphosate (2016: 1).

Another consequence that peasants associate with the use of agrochemicals is the deterioration of native maize and seeds. According to Josefa, a young non-Zapatista mestiza woman from Teopisca: "when you put chemicals in the land you kill everything, all the organisms that live there, including all the insects and worms that feed the plants. You just kill everything. That results in land that is not oxygenated, nourished, and you can see the consequences, as a reflection, in the maize." ${ }^{, 52}$ Several peasants echo the 
concern that seeds might be affected by the use of agrochemicals, although they frame the issue in different terms. "The seeds have become smaller; both the maize cob and the kernels have decreased in size. It is like they have become sterile. It is like if a modification of its cell, of its heart, had occurred," says Ana, a non-Zapatista mestiza woman in her thirties from Tumbalá. "This modification has made the maize and the land dependent [on the fertilizer]. They are not reproducing themselves if you don't give them chemicals. We also see now that many seeds rot very easily, they don't resist well. Maybe there are some new pests or diseases. We don't know. This is something that didn't happen before, ${ }^{, 53}$ she adds.

Javier, a Zapatista Tsotsil in his thirties from San Andrés, expands this argument and comments on the productivity of the milpa and its dependence on the use of agrochemicals: "you might have green milpas, but that is just in appearance because they won't give you elote [maize cobs]. You need to use fertilizer to have elotes. The milpa is not growing well anymore, now it is much shorter, chaparra as we say here, and it does not give more elote if you don't use fertilizers. As we say in my community, 'both the soil and the seed became accustomed to being fed with chemical fertilizers,' and that is a very serious problem.".54

Peasants also identified broader health problems related to the use of agrochemicals. "In these communities you can find some diseases that we did not have before. Many people here now have cancer, leukemia, diabetes, or skin problems," says Marcela, a young Tsotsil health promoter from the Caracol of Oventic. "It might be related to the use of chemicals. For instance, people here use the chemicals without any 
real protection. Many times people would say that the chemical, the poison, spilled out from the spray pump, over their backs. Maybe the first time it is something that you cannot feel, but after years your body will resent this poisoning. And you see how many people have serious health problems here." 55

Another widespread perception among these communities is that the use of agrochemicals might be affecting people's health in more indirect ways - for instance, through the consumption of food. "My youngest son is sick all the time. We don't know where the diseases come from. I think that they come from the food we are eating, from so many chemicals we put in it. It might also come from the food we buy in the store," comments Salvador, a non-Zapatista Tsotsil man in his thirties from San Andrés. "We have forgotten the practices of our ancestors. Our grandparents had other forms of taking care of the land and the milpa worked well. Children were not eating Maruchan [a commercial instant ramen soup]. There was less disease, less hunger."

Salvador's comment reveals two other structural problems closely related to the loss of productivity of the milpa: food insecurity and a drastic change in the diets of these communities, two problems affecting particularly the youngest. "Now we cultivate very few things because the land is ill," says Agustino, a non-Zapatista Tseltal man in his sixties from Cancuc. "Before, we had more vegetables and fruits, and the women carried their backs full with crops from the milpa. Now it is different, we only eat maize and beans, and our maize is sick too. It is turning yellow, it is not doing very well." ${ }^{, 57}$ Julian, a Zapatista Tsotsil man in his thirties from San Andrés, concurs: "We are not eating well. We love to drink Coca-Cola and eat Sabritas and Maruchan, and our children do the 
same, they learn from us." Then, he adds: "I don't believe that we are thinking correctly. We can see that those producing organically have better milpas. They might suffer from contamination coming from neighboring milpas where people use chemicals, but they have better harvests. Their milpas produce better than ours, they have more food." ${ }^{, 58}$ Coupled with the potential contributions of agrochemicals to the deterioration of the milpa system, there are other environmental problems in the study area that may be related to climate change. The most frequently mentioned issues in the region are changes in the rainy and dry seasons and the presence of new crop diseases. Ruben, a nonZapatista Tseltal man from Cancuc, talks about the roya, a coffee disease that has expanded throughout the region in the last five years and is affecting many of the indigenous communities in this study. "This year I lost all my coffee because of the roya," says Ruben. "I only produced 30 pounds of coffee this year. This is the fourth year with this problem and the situation is really bad. I'll try a new variety that is supposed to be resistant to the roya; let's see how it works. ${ }^{, 59}$ I heard similar comments about the roya in almost all of the indigenous communities that I visited. Indeed, Chiapas has been the Mexican state most heavily impacted by this disease, with about 37 percent of all coffee producers affected (González 2016, SENASICA 2013).

Regarding changes in precipitation, the mestizo communities located in the region of Venustiano Carranza have been severely affected by a drought that, at the moment of my fieldwork, had lasted for almost four years. Marta, a non-Zapatista woman in her forties, says: "We cannot have a vegetable garden here anymore because we don't have water. Before, it rained better. We had all this space full of flowers and herbs, some 
vegetables too. It was very beautiful, full of colors, all green. Now everything is dry...I really hope God will give us a little more rain this year. The truth is that we are in a very tough situation." ${ }^{\circ 0}$

The lack of rain has devastating effects on these communities, particularly among children, because it directly impacts households' food security. "Here we produce the milpa, but it is not enough food. We are whole families eating from the same land, too many people and too little food," says Maricela, a twenty-four-year-old mother of two. "The last years have been very ugly because we have not had enough rain. It is the fourth year that has not rained properly and we are losing our harvests. If even before the drought we did not have enough maize, now it is much worse." Maricela starts crying and her sister, Esmeralda, who is thirty-one years old and a mother of three, picks up the conversation: "There has not been enough food and we went hungry. The last year we did not even have beans, just tortillas and pozol [a maize beverage]. The few beans we had, we gave to the children. At least some days they had one tortilla with beans. The situation has been awful." ${ }^{\prime 61}$

As Mercer et al. point out, although subsistence farmers "contribute little carbon emissions to the Earth's atmosphere, they tend to be especially vulnerable to climatic flux" (2012: 495). Emanuel Gómez, a researcher from the University of Chapingo in San Cristóbal, expands on this topic during our interview: "here in the region, all peasant communities develop rainfed agriculture. This means that they completely depend on the rain. There are no irrigation systems that could help them to get through a drought. Even if climate change is almost imperceptible for people like us in the cities, for those 
communities it is a disaster because they are losing their production. They lose their food for the year.",62

In these adverse situations, households' economies are squeezed even more because families have to spend the little cash they earn to buy food that otherwise would be produced in the milpa. "Now we need to buy everything, including maize and beans. We don't have vegetables and never eat fruit. The rainy season is becoming shorter and shorter, and we are not having good harvests. Even before, when we had rain, we did not have enough maize. Now the situation is much worse," explains Jaime, a thirty-two-yearold father of three. "We have to complement with some maize that we buy in Santa Lucia [a neighboring town, one hour away], but it is very expensive. One bucket [about 40 pounds of maize] costs 100 pesos [US\$5]. Sometimes, if we have some extra money we will buy some beans. That is how we complement. ${ }^{63}$

Taken together, these narratives paint a nuanced picture of how communities experience interlinked environmental degradation and food insecurity issues, some of them arguably caused by the intensive use of agrochemicals and the consequent deterioration of the milpa system. "How can communities live in a situation in which the water, the land, the seeds, and the food are all polluted? How can they survive in a world of junk food?" asks Sebastian, the former director of DESMI.

The collective reflection and discussion of these issues and the proposition of alternatives - what the diocese of San Cristóbal calls the exercises of seeing, reflecting, and acting [ejercicios del ver, reflexionar, y actuar] — are a central part of the food and seed sovereignty agenda that is now evolving in the region. The seed sovereignty 
workshop that DESMI presented in San Andrés in October 2015 offers a good example of these discussions. During the Mayan Altar ceremony preceding the workshop, Domingo, the Tsotsil deacon who is leading the ceremony, addresses the audience:

We are poor and desperate, and our hearts are closed because of so many difficulties. We are not taking care of either Mother Earth or our communities.

Our lands are exhausted; they are not giving us enough food any more. Our rivers are polluted and everywhere we find garbage. Our bodies are marked with illness and the youngest suffer from diseases because they are not eating properly. We are not living in harmony with our ancestors. We need to find our path again, the path that our ancestors traced for us...We know that it is not easy, and that is the reason we are asking for guidance. We have to be humble and ask for forgiveness and for insight. Our ancestors knew how to live in harmony as Mayan peoples. We should be ashamed because we have lost insight. But we are here to find our path, the path of our ancestors. ${ }^{64}$

After the ceremony, Margarita, the mestiza Catholic nun who organized the workshop, speaks to the audience:

We are here to continue our study and reflection on the Encyclical Letter. As all of you know, Pope Francis has urged us to reflect on what our responsibilities are, and how we can take care of our common home, Mother Earth. Asking for forgiveness is important. That is the reason why we just had our forgiveness ceremony. But that is not enough. We have to change and make things different. We need to think about solutions. That is part of the Encyclical letter too...The 
Mother Earth is our home and we are responsible for it. Without nature, without our lands, we are nothing. All of us come from the land, from the seeds that grow on the land. We all have the same origin. We cannot continue destroying our source of life. We have to think with clarity about the consequences of our actions. Does the use of chemicals help us to preserve our milpas, our rivers, our seeds, the health of our communities? Is comida chatarra [junk food] healthy for our children? How can we heal the division among brothers and sisters that is destroying our communities? We, as part of the ministry, have the responsibility to reflect on our problems and find solutions for our communities. We have the responsibility to spread God's words among our communities. ${ }^{65}$

At the end of her presentation, I ask Margarita why they have decided to organize a workshop on seeds among these non-Zapatista communities, and she responds that: We see native seeds as the basis of these communities, of their diets, and their culture....we believe that taking care of seeds is a good way to unify and reconcile communities that are living in conflict. These are communities that are divided, they are very poor, and have many problems. In this region the conflicts and divisions among people from different political parties and religions are very serious. We have also the problem of the narco [drug trafficking], there is a lot of violence...We believe that seeds are something that all we have in common in this region. Seeds can help us to create solidarity among these communities. ${ }^{66}$ 


\section{Conclusion}

Focusing on some of the agricultural practices that shape communities' native seed systems in Chiapas, this chapter has addressed the increasingly contested relationship between formal and informal seed systems under neoliberalism. Aside from international treaties and national laws aiming to articulate private industrial seed systems at a global scale, the development of industrial agriculture has had several other-more direct—impacts on these communities' agricultural systems and seeds.

Two of the most straightforward outcomes are the adoption by these communities of agrochemicals and industrial processed food. Contrary to the premises of Green Revolution policies, industrial seeds have not displaced native seeds in this region. However, peasant communities have indeed adopted the agrochemical inputs that accompany industrial seeds. This process has entailed the chemicalization of peasant agriculture, with the attendant negative consequences for communities' ecosystems, health, and food security.

One relevant result of this chemicalization has been the partial abandonment of the milpa system and its simplification to a single species each of maize and beans. This minimization and deterioration of subsistence agriculture has been accompanied by peasants' increasing dependence on food markets to complement self-produced food. This process reflects the weakening - although only partially_of the economic role of the milpa as the fundamental source of food for these households. Changes in diets, specifically the mass consumption of processed food, may also be related to this economic transition. More research is needed in order to determine whether there is a 
causal link between both processes. However, it is clear that the commodification of these communities' diets is firmly advancing. It is possible to affirm this because communities increasingly rely on agrochemicals for the production of their own food, on food markets for meeting their food consumption needs (including junk food), and on labor markets for assuring a source of cash income in order to buy food.

I would argue that as long as subsistence agriculture continues to lose relevance for these communities, native seeds will lose relevance as well. Paradoxically, although the privatization of native seeds is not presently a tangible, immediate threat to these communities - in contrast to the deterioration of subsistence agriculture, which is - it has nonetheless become one of the core foci of the seed and food sovereignty agenda that is emerging in the region. This development is not exclusive to Chiapas but is part of a nationwide countermovement that responds to the liberalization of the maize market under NAFTA and the introduction of GMOs, essentially U.S. corn and soybeans.

The politicization of native seeds at national scale, particularly native maize, around the issues of seed privatization, the introduction of GMOs, and the monopolization of global seed markets by a few corporations, has had several positive consequences for these communities. Among these positive effects is the re-signification of maize as the core staple food of Mexican people and the leading role that peasant agriculture and the milpa system play in the preservation and reproduction of maize agrobiodiversity.

The political dichotomy between native maize and industrial corn, and between national food security and food dependency (Baker 2013), has also put at the center of the 
debate the issues of rural poverty and peasant food insecurity under neoliberalism and their impacts on communities - including mass migration, the displacement of food crops by drug crops, the feminization of agriculture, and the increasing incorporation of peasants into waged labor markets (Busch and Geohegan 2010, Camou Guerrero 2015, de Janvry et al. 2015, Radel et al. 2012). Although subsistence agriculture, which is represented by the milpa, continues to be a fundamental source of food for more than two million households in Mexico (Eakin et al. 2014a: 134, Perales 2016: 272), it is unquestionable that it is losing economic importance relative to cash income and food markets.

This development has brought into the discussion another important topic that transcends economic and food security considerations: the need to preserve agrobiodiversity, a preeminent issue in a context marked by climate change (Bellon et al. 2011, Mercer et al. 2010, 2012, Ureta et al. 2012). A direct consequence of increasing biodiversity loss and climate change has been the emergence of an environmental consciousness that critically refutes some of the paradigms of industrial agriculture and highlights its damaging effects on ecosystems and agro-biodiversity (Camou Guerrero 2015, Siegel and Betz 2016). This relatively novel ecological understanding has directly contributed to the re-valorization of the milpa system. However, this re-valorization has not been uncritical, and the search for alternatives to those practices that are no longer sustainable — such as slash-burn-and-fallow methods, which have considerably contributed to deforestation — has opened up a valuable discussion about the potential of adapting the milpa system to contemporary environmental conditions (Diemont et al. 
2005, Lawrence et al. 2007, Nigh and Diemont 2013, Ochoa-Gaona and GonzálezEspinosa 1999). The following chapters further develop the discussion of these topics.

I want to conclude this chapter by emphasizing that even if the milpa system has lost economic relevance in a neoliberal context that deprioritizes peasant agriculture, its reproduction continues to be a vital element of the subsistence of peasant communities in Chiapas, as it has been for about 2,000 years. Native maize has been present in the lives of these peoples for almost 9,000 years, and a central component of their diets for some 3,000 years (Buckler and Stevens 2005: 71, Ford and Nigh 2009: 223, Piperno et al. 2009: 5019, Wilkes 2004: 9). Today, native maize is still the fundamental food of these communities (Gómez Martínez 2016). These elements must be considered when analyzing the implications of neoliberal and industrial agriculture policies for the development of peasant communities and their ecosystems. These issues also suggest the scale of the challenges that the seed and food sovereignty agenda in the region will have to address. 


\section{CHAPTER FIVE}

"WITHOUT FOOD THERE IS NO RESISTANCE":

\section{SEED AND FOOD SOVEREIGNTY AS DECOMMODIFICATION}

Agriculture is something essential for humanity. When you disarticulate agriculture from the logics of capitalism, you are disarticulating many other aspects of humanity that are dominated by such logics. Our relationship with nature, and the ways we produce, exchange, and consume food are modified. You just break many of the logics and dynamics established by the capitalist system.

Luis, Cideci-UniTierra ${ }^{1}$

Attaining food sovereignty is not the objective itself, but it is part of a wider struggle for building an alternative society. It is about changing our utilitarian relationship with nature, the territory, and other living beings. The most essential element in this equation is to produce our own food without destroying the environment.

Sebastian, DESMI's former director ${ }^{2}$

"Without food there is no resistance." This was a recurring phrase I heard during my research in rebel territory in Chiapas - in Zapatista communities, in communities that adhered to the pro-Zapatista La Otra Campaña (The Other Campaign), and other spaces where the EZLN has a strong influence. This is also one of the core principles driving the seed and food sovereignty agenda of the Zapatista movement. It implies both the goal of attaining food security in a context of low-intensity war and the recognition that subsistence agriculture and the milpa system are the material, cultural, and spiritual foundations of these peasant communities (EZLN 2014a, 2014b, 2014c, 2014d, 2015). 
But what is meant by food and seed sovereignty? Mariano, a DESMI staff member who has worked in the organization for 13 years, advances a definition:

Seed and food sovereignty is the right of these communities to remain on the land and preserve their identities and way of life as Mayan peoples. Native seeds represent the origin of these communities, where they come from, what they eat, and who they are. Beyond the milpa, native seeds are linked to the territory and its ecosystems - the concrete space in which such sovereignty can exist. When you talk about native seeds as the subsistence base of these communities, you need to think about not only food but also the territory. That is why it is so natural for indigenous people to make the connection between the defense of native seeds and the defense of the territory: for them these two elements are not separated. Native seeds represent the soul of the territory. ${ }^{3}$

As I have suggested earlier, seed and food sovereignty have become a key element of the Zapatista struggle for indigenous autonomy (EZLN 2014a, 2014b, 2014c, 2014d, 2015). But where do these ideas come from? How do they relate to the Zapatista project of indigenous autonomy? What role has DESMI played in the definition of this decommodification agenda? How has this idea of seed and food sovereignty spread to non-Zapatista communities? This chapter addresses these questions and establishes the context for analyzing DESMI's Guardians of Mother Earth and Seeds project, which is the objective of Chapter 6 . 


\section{Almost 50 Years on the Ground: \\ DESMI, Solidarity Economy, and Indigenous Autonomy}

As I mentioned in the introduction, the story of DESMI is intimately linked to the development of the Zapatista movement and its struggle for indigenous autonomy. Since 1969, this small organization — whose staff has fluctuated between five and 25 peoplehas worked side by side with indigenous peoples in this region to build communitydriven development projects. Today, DESMI collaborates with more than 200 communities, the large majority of which are Zapatista autonomous communities from the Oventic and Roberto Barrios Caracoles (see Figures 9 and 10).

Throughout its history, DESMI has committed most of its work to developing a solidarity economy model — which I identify as one of the direct precedents of the decommodification and anti-capitalist stance of the Zapatista movement (see Table 9). A quote from the organization's website helps to illustrate this concept:

The foundations of a solidarity economy are the groups of peoples who, rooted in collective practices, seek to develop solidarity relations and mutual support networks among individuals and communities. Through the process of building an alternative economy based on solidarity precepts, communities are strengthened and their members become social subjects capable of taking their future into their own hands. In opposition to a capitalist economy that is driven by the principles of accumulation, individual material growth, overconsumption, and competitiveness, we believe in an economy that prioritizes solidarity among humans, is in harmony with the environment, and supports the collective growth 
of communities (DESMI 2017).

Mariano, whom I introduced above, frames these ideas in practical terms while describing the organization's goals and principles:

A key part of DESMI's work consists of supporting these communities to develop the collective skills they need in order to create and sustain solidarity projects such as cooperatives, infrastructure [projects], or even peasant-to-peasant training programs. These projects are born from the communities and they aim to improving the living conditions of all their members. For instance, we always try to give priority to those projects in which women can take leading roles such as women-only cooperatives, organic vegetable gardens, or seed banks. Clearly, these projects do not resolve all the problems of these communities, but they offer an alternative understanding of what a community means. The idea is that we can all be better if we work together to benefit each other. That is essential to building autonomy. 4 

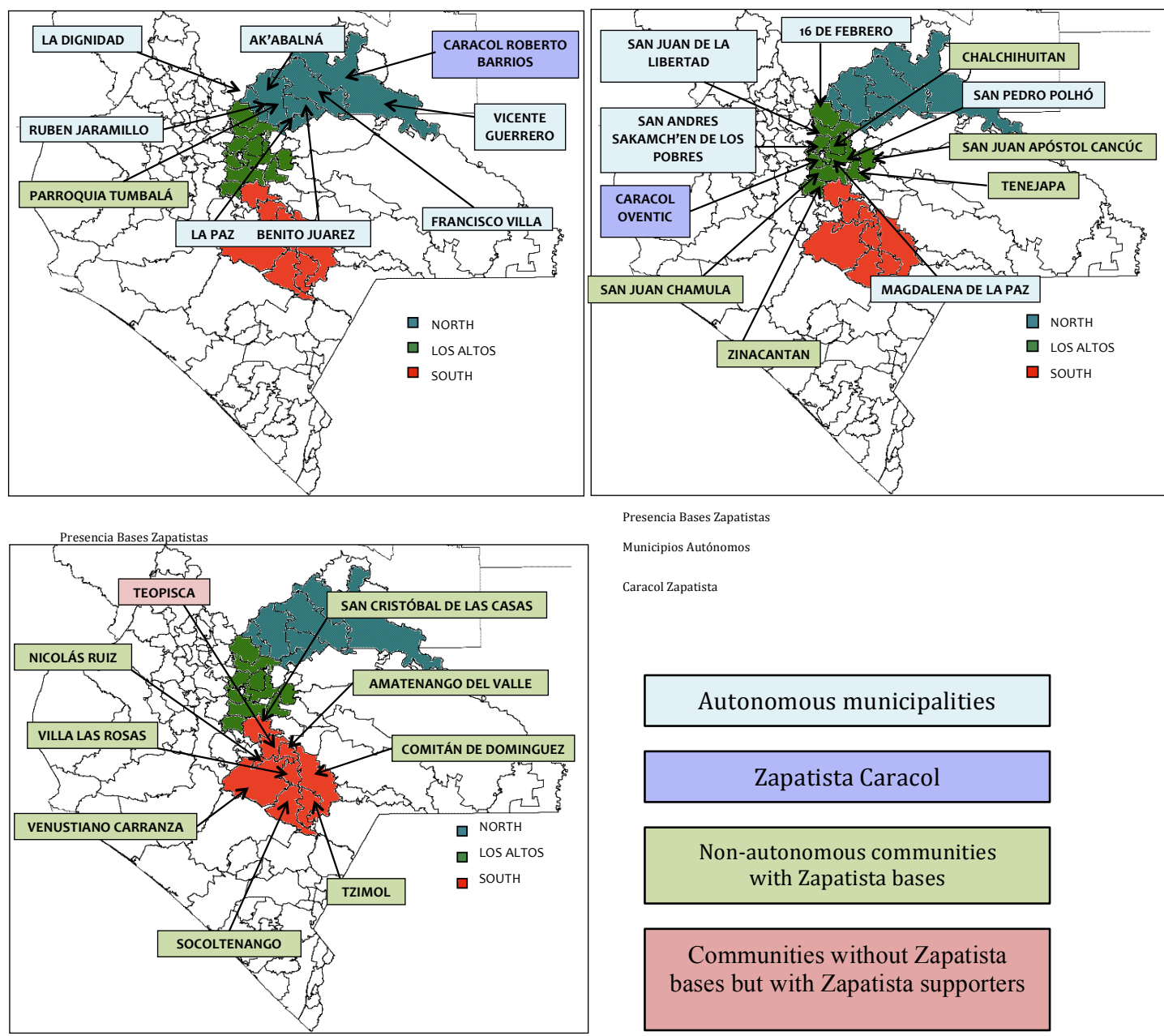

Figure 9. DESMI's area of work, by regions and municipalities, 2018. Author's elaboration based on DESMI (2009: 145). 
Figure 10. DESMI's Organization by Type of Community, 2018

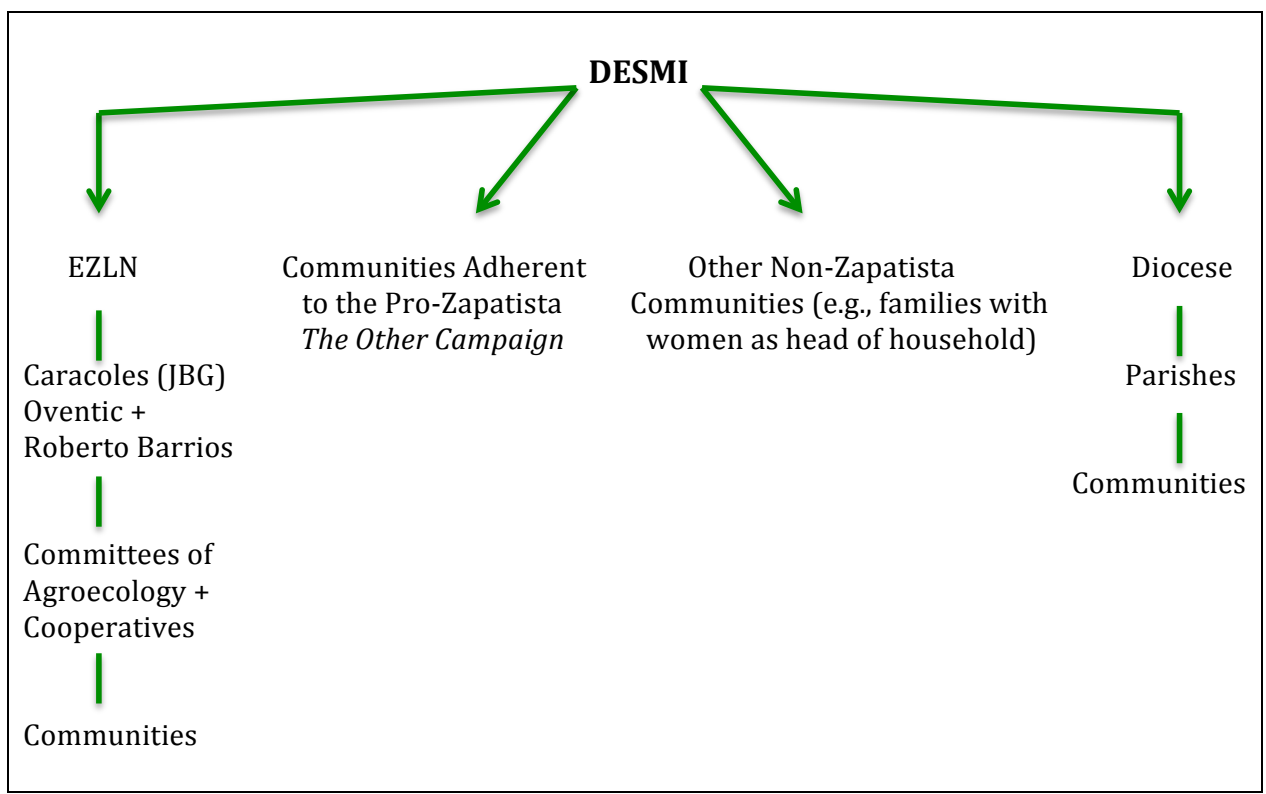

Source: Author's elaboration based on DESMI's internal documents.

Table 9. DESMI's Projects: Key Foci, 2018

\begin{tabular}{|c|c|}
\hline Solidarity economy & $\begin{array}{l}\text { - } \quad \text { Cooperatives and collectives } \\
\text { - } \quad \text { Solidarity markets and networks } \\
\text { - } \\
\text { - } \quad \text { Sociternative certification programs } \\
\text { ecological justice precepts }\end{array}$ \\
\hline Agroecology & $\begin{array}{l}\text { - } \text { Organic production and soil recovery } \\
\text { - } \text { Agroforestry and the milpa } \text { system } \\
\text { - Ethno-veterinary } \\
\text { - } \text { Eco-technology } \\
\text { - } \quad \text { Adative seed breeding, conservation, and evolution } \\
\text { - climate change }\end{array}$ \\
\hline $\begin{array}{l}\text { Food and seed } \\
\text { sovereignty }\end{array}$ & $\begin{array}{l}\text { - Food security } \\
\text { - Diversification of the milpa } \\
\text { - Complementing the milpa: organic vegetable and herb } \\
\text { - } \text { gardens, animal-raising and bread-baking projects } \\
\text { - Seed exchange and participatory breeding techniques } \\
\text { - Anti-GMO stance }\end{array}$ \\
\hline
\end{tabular}




\begin{tabular}{|c|c|}
\hline Training & - Peasant-to-peasant methodologies \\
\hline Women's rights & $\begin{array}{l}\text { - Political and economic rights } \\
\text { - Training and support to women-only collectives and } \\
\text { cooperatives } \\
\text { - Infrastructure that benefits women's health and reduces } \\
\text { their housework, such as firewood saving stoves, dry } \\
\text { latrines, and potable water and rainwater collection } \\
\text { systems } \\
\text { - Direct participation in food production: vegetable gardens } \\
\text { and animal-raising } \\
\text { - Food diversification and nutritional workshops focused on } \\
\text { women's and children's health }\end{array}$ \\
\hline $\begin{array}{l}\text { Context analysis } \\
\text { and political } \\
\text { economy }\end{array}$ & - Context analysis and political economy workshops \\
\hline
\end{tabular}

Source: Author's elaboration based on DESMI's internal documents and fieldwork.

Table 10. DESMI's Projects in Zapatista and Non-Zapatista Communities, 2018

\begin{tabular}{|c|l|}
\hline Key Actors & \multicolumn{1}{c|}{ Zapatista Communities } \\
\hline $\begin{array}{c}\text { Earacoles } \\
\text { (JBG) }\end{array}$ & $\begin{array}{l}\text { Infrastructure: firewood saving stoves; dry latrines; potable water and } \\
\text { rainwater collection systems. } \\
\text { Collectives and cooperatives: credit unions; organic coffee* and honey* } \\
\text { cooperatives; mushroom, maize, bean, and fruit production collectives. }\end{array}$ \\
$\begin{array}{c}\text { Agroecology } \\
\text { Committees }+\end{array}$ & $\begin{array}{l}\text { Women-focused collectives and cooperatives: organic vegetable and herb } \\
\text { gardens; bread-baking cooperatives; chicken, rabbit, and pig-raising } \\
\text { cooperatives; grocery cooperatives; artisan* cooperatives; herbal remedy, } \\
\text { soap, and jam production collectives. } \\
\text { Communities } \\
\text { Indigenous) }\end{array}$ \\
$\begin{array}{l}\text { Training in agroecology, ethno-veterinary, and agroforestry systems: soil } \\
\text { recovery and conservation techniques; organic fertilizer, herbicide, and } \\
\text { pesticide labs; composting; collective organic nurseries; seed conservation and } \\
\text { breeding techniques; reforestation and the milpa system; climate change } \\
\text { adaptation strategies. }\end{array}$ \\
$\begin{array}{l}\text { Training in peasant-to-peasant methodologies: development and transfer of } \\
\text { collective knowledge; participatory techniques and women's participation; } \\
\text { coordination and supervision of projects at the regional and community level; } \\
\text { design of sustainable projects. }\end{array}$ \\
\hline
\end{tabular}




\begin{tabular}{|c|c|}
\hline & Non- Zapatista Communities \\
\hline Diocese & $\begin{array}{l}\text { Infrastructure: firewood saving stoves; dry latrines; potable water and } \\
\text { rainwater collection systems. }\end{array}$ \\
\hline $\begin{array}{l}\text { Parishes } \\
\text { Communities } \\
\text { (Indigenous) }\end{array}$ & $\begin{array}{l}\text { Context analysis and political economy workshops: analysis and discussion } \\
\text { of relevant political and economic events affecting communities (e.g., federal } \\
\text { laws on seeds). In some of these workshops, DESMI presents topics that were } \\
\text { discussed in the international seminar "Critical Thought Against the Capitalist } \\
\text { Hydra," which was organized by the EZLN and the Cideci in } 2015 \text {. }\end{array}$ \\
\hline $\begin{array}{l}\text { Adherents to } \\
\text { the }\end{array}$ & $\begin{array}{l}\text { Collectives and cooperatives: organic coffee production; alternative } \\
\text { certification processes, }{ }^{* *} \text { panela [molasses] and mushroom production. }\end{array}$ \\
\hline $\begin{array}{l}\text { Pro-Zapatista } \\
\text { The Other } \\
\text { Campaign }\end{array}$ & $\begin{array}{l}\text { Women-focused collectives: organic vegetable and herb gardens; bread- } \\
\text { baking, chicken-raising, and herbal remedy-making collectives. }\end{array}$ \\
\hline $\begin{array}{l}\text { (Mestizo) } \\
+ \\
+\end{array}$ & $\begin{array}{l}\text { Training in agroecology and food security: basic soil recovery and } \\
\text { conservation techniques; composting and organic fertilizers and herbicides; } \\
\text { collective organic coffee nurseries; diet improvement. }\end{array}$ \\
\hline $\begin{array}{l}\text { Other Non- } \\
\text { Zapatista } \\
\text { Communities } \\
\text { (Mestizo) }\end{array}$ & $\begin{array}{l}\text { Seed sovereignty: workshops on seed laws and GMOs; community native } \\
\text { seed inventories and seed banks; seed conservation techniques; organic } \\
\text { vegetable gardens. }\end{array}$ \\
\hline
\end{tabular}

Source: Author's own elaboration based on DESMI's internal documents and fieldwork.

* The production of coffee, honey, and crafts is mostly focused on foreign solidarity markets. The rest of the products are focused on internal consumption or local markets. Some surpluses are sold in regional solidarity markets (e.g., San Cristóbal de las Casas, and Mexico City). ** DESMI is helping to create a regional solidarity coffee certification program embedded in the institutional structures of the diocese. Different from the expensive and very restrictive international fair trade and organic certification bodies. The idea is to create an analogous model to the well-established solidarity market for Zapatista coffee in European countries.

\section{The Beginnings: Liberation Theology, the Diocese of San Cristóbal,}

\section{and the Guerrilla Movement}

Any account of both DESMI and the EZLN would be incomplete without referring to the diocese of San Cristóbal and its progressive archbishop Samuel Ruiz, who led it from 1969 to 1999 (see Figure 11). Influenced by liberation theology 
doctrines, Samuel Ruiz was one of Mexico's foremost advocates of the rights of indigenous people and the institutionalization of an indigenous deaconate in the Catholic Church — taking a stance in a controversy dating back to the colonial period, when it was debated whether indigenous people were fully humans and deserved to become part of the institution ${ }^{5}$ (Dumont 2009, Ruiz García 2006: 161).
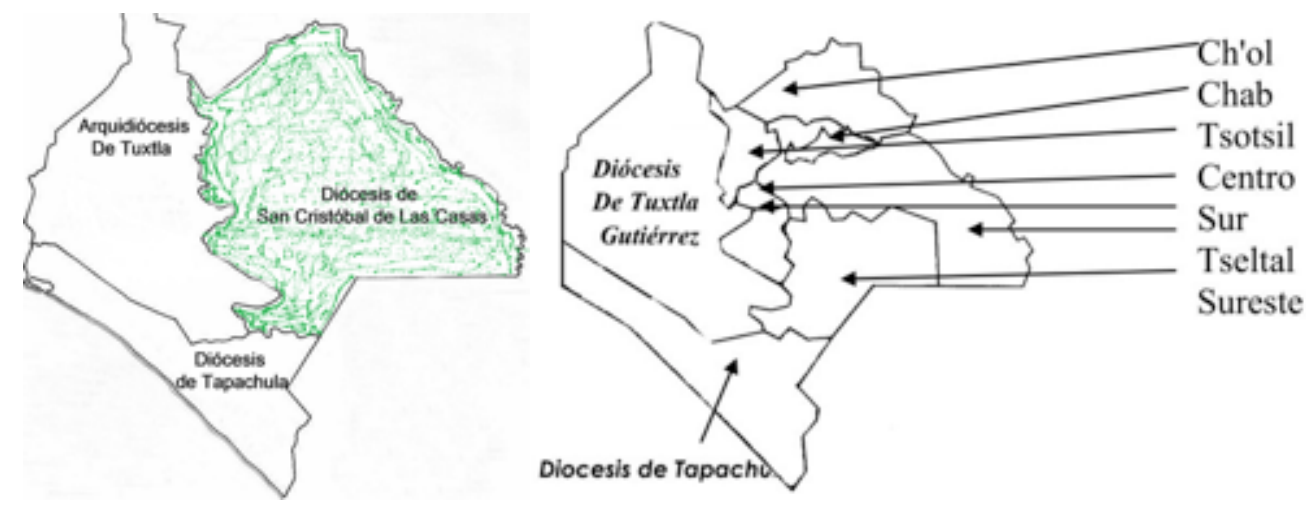

Figure 11. Diocese of San Cristóbal de las Casas and its seven regions (reprinted from Cáritas 2017, Diocese 2013).

jTatic Samuel_-"grandfather" or "beloved father" in Tseltal and Tsotsil, as he was lovingly called by members of indigenous communities—dedicated his administration to encouraging indigenous communities to engage in social action and create their own development projects. In order to support indigenous communities in their organizational processes, he created an institutional network of civil society organizations. ${ }^{6}$ Although independent, these institutions have remained closely related to the diocese and its project of indigenous development, and many of the international organizations, NGOs, and activist groups that work today in the region, particularly with the EZLN, are intimately linked to that network (Ruiz García 2006 ).

In line with the traditional charity structure of the Catholic Church, the first years 
of DESMI were focused on financing small-scale infrastructure projects and relief programs for indigenous communities. The objective was, in the words of the organization, "to make these people's life more bearable, to reduce their suffering [hacer la vida de estas personas más aguantable, reducer su sufrimiento]" (DESMI 2009). In an attempt to move beyond this charitable orientation, DESMI became an independent organization in 1974. Sebastian, who was a member of the pastoral himself and a close collaborator of Samuel Ruiz, became DESMI's first director. This was the moment when DESMI embarked on the project of building a solidarity economy model (DESMI 2001). Sebastian explains some of the concerns that inspired this project:

The central question for us was how to improve the agricultural and food systems of these communities while creating and strengthening collective systems of production. You need to keep in mind that these communities were very poor, densely populated, and with lands that were not suitable for agriculture. Their food production was strictly limited to subsistence needs, and the few things they produced for the market were always underpaid, practically stolen. The [agricultural] production of indigenous peasants was most of the time caught up in one of three situations, all of them dominated by mestizo people: to pay back peasants' perpetual debts with the patrón or local lenders; to sell it to the coyote at very low prices, and frequently just in exchange for overrated groceries; or, in those cases where indigenous people had access to the towns, to be stolen by the enganchadores [groups of mestizo people whose purpose was to assault indigenous people and steal their merchandise, mainly at the entry to towns or 
plaza-markets]. You can still see these dynamics, they have not disappeared yet. Furthermore, many of these communities were still attached to the fincas and their semi-bondage system of labor.

Breaking, or at least weakening, this cycle of exploitation, indebtedness, and decapitalization of indigenous communities was one of DESMI's main objectives in that period. The idea was to create the essential economic and social conditions in which development projects could be rooted. To achieve this goal, DESMI created a revolving loan fund to finance the collectivization of these communities' production systems. Sebastian refers to this process:

In 1979, we created a revolving fund that communities could use to start or improve their collectives; the main condition was that the loans — which had an interest rate of 1 percent — had to be used in the collectives. We also supported the creation of community credit unions. The idea was to help these communities to capitalize themselves and reduce their dependence on the patrón, the coyotes, and the merchants in the towns.

We had to start from scratch. Many of our workshops were focused on learning how to calculate the costs of production, and that implied teaching people basic mathematics, and frequently how to read and write. We believed that, in order to overcome such adverse conditions, it was necessary to build a collective social subject. It was clear for us that only together, as communities, would it be possible to create an alternative to that situation of extreme poverty, exploitation, and violence. ${ }^{7}$ 
DESMI's transition from a charity project to a solidarity economy model can be better understood in light of the Indigenous Congress that took place in San Cristóbal de las Casas in 1974 (Table 11 identifies key events in the development of DESMI and the EZLN). ${ }^{8}$ Organized by the diocese, the Congress brought together 1,230 representatives of 376 communities from across the region. Its purpose was to discuss and propose solutions to the main problems that communities were facing. Four topics were discussed: land, health, education, and economy. As several scholarly studies have emphasized, the Indigenous Congress proved to be one of the most important events in the contemporary history of Chiapas because a whole set of peasant organizations were born out of it ${ }^{9}$ - including the predecessors of the EZLN (Aubry 2004, Cedillo 2010, 2008, García de León 1995, Le Bot 1997, Lerna Rodríguez 2015, Leyva Solano and Ascencio 1996, Santiago 2016a, 2016b). Although this is not the focus of this chapter, it is worth highlighting that most of the peasant organizations that emerged in those years were demanding agrarian reform and/or occupying land, both from private finca land and federal land in the rainforest. Indeed, this process of land occupation proved to be crucial for the capitalization and organization of some of the indigenous communities that later would comprise the Zapatista guerrilla movement (see Table 11) (Cedillo 2010, de Vos 2002, Leyva Solano and Ascencio 1996).

Between 1974 and 1994, DESMI concentrated its efforts on consolidating its solidarity economy model—including the articulation of regional, national, and international networks of solidarity organizations - and supporting communities' political organizing. ${ }^{10}$ These were the years in which DESMI arranged multiple regional 
encounters with most of the 120 communities it worked with. These encounters helped communities to share their organizational experiences and consolidate solidarity networks among them (DESMI 2001).

Underlying this work was the clandestine organization of the EZLN, in which DESMI would play a crucial role as one of several bridges of communication between the guerrilla movement located in the Lacandon rainforest in eastern Chiapas, and the communities in Los Altos, Norte, and Sur. ${ }^{11}$ Maricela, a mestiza nun who worked in the northern region between 1976 and 1993, and who had the opportunity to collaborate with DESMI on several projects, shares her experiences, emphasizing the conditions of repression and violence in which DESMI and the diocese had to work during those years: When we first heard about a clandestine movement that was being organized far away in the rainforest, DESMI had already been working in this region [in the North] for years. Just like us [members of the pastoral], the people from DESMI were truly committed to those communities. People trusted DESMI, and it was only because of all the hard work of its members. It was not a joke. They were risking their lives there. It was the land of terratenientes and their guardias blancas [paramilitary forces], and the law of the patrón was the only law there. They [the paramilitaries] were threatening us all the time. When we were walking alone from one community to another, someone on a horse would approach and tell us something like "little sisters, sooner than later you will be with your God and his pinches indios [damn indios]"; and then, you would see all those criminals and their patrones praying during the Sunday service — what cynicism! It was the 
same for the people of DESMI. They were walking for hours from community to community, eating the same as the rest of the people there, just tortillas and beans.

Maricela also refers to the key role that DESMI played as an external agent who introduced new ideas and information to these communities. From challenging traditional gender roles to introducing the guerrilla movement to these communities, DESMI was a catalyst of social change in the region. Maricela continues,

When we [the members of the parish] asked for help, they [DESMI] would always send people well trained to explain things about agriculture, women's participation, or any other topic. We had a lot of workshops and began to work in some collectives. I particularly liked Lucila, an agronomist from Chapingo [an agrarian university near Mexico City]. She was a sensation: a woman traveling alone and teaching men about agriculture! I would always laugh just to see how people reacted. But communities liked her, they always liked people from DESMI.

At the time we first heard about the guerrillas, we all already trusted DESMI. People were open to seeing what this movement was about. Now you can see the outcome. It was not a joke; they knew what they were doing. I still cannot believe that nobody killed me in those days. In 1994, after the armed uprising, I was sure that they [the government] would jail me too. I think it was God who protected me because I was doing my work helping these people to organize. ${ }^{12}$ 
Mateo, another member of the pastoral who worked in Los Altos in the 1980s, complements Maricela's narrative and explains how, simultaneous to the organization of cooperatives and development projects, these communities also embraced the guerrilla movement. As this quote illustrates, the figure of Samuel Ruiz was important reference in defining how pastoral members understood the diocese's work and its responsibility to support these communities in their organizing process:

We had our meetings [with DESMI] in the coffee plots [cafetales] or the milpas. It was safer that way because the guardias blancas did not follow us inside. We had just started the coffee cooperative and were having all those workshops about agriculture, but we were also talking about the organization [the EZLN] and how to bring our communities into the struggle...We also had some meetings in the middle of the night, when someone from the organization [EZLN] would visit the community and give us some information. We never saw their faces or knew their names. They only came on days without moonlight, and they always left before dawn. We all had to be very careful with the information and meticulous in our actions. Indeed, that is why the organization [the EZLN] prohibited the consumption of alcohol in the first place. We were working in very risky conditions, but it was important for these communities and they decided to take on the responsibility. That is how people in this region started to join the organization [EZLN]. As members of the pastoral, we were committed to supporting them. We had taken our votes, and jTatic Samuel was our example. That is why he was called "the walker," because he was always walking from 
community to community, listening and helping people. I heard that he visited all the communities of the diocese. Our pastoral was there, to walk side by side with the poor. ${ }^{13}$

At the time of the Zapatista uprising, all of the communities DESMI was working with were Zapatista communities ${ }^{14}$ (DESMI 2001, 2009). In the few months that followed the armed uprising, several members of the diocese, including Sebastian—who had been the director of DESMI since 1974—were imprisoned by the federal government on the charge of having contributed to the guerrilla movement (Ruiz García 2006: 135). ${ }^{15}$ Even archbishop Samuel Ruiz was interrogated and identified as one of the main figures leading the Zapatista movement (Santiago 1999). However, as a result of the strong pressure that civil society and international human rights organizations exerted on the government, Sebastian and most of the other pastoral members were freed after several months. Indeed, it was Samuel Ruiz who would become one of the key mediators in the peace dialogue between the EZLN and the Mexican government (Ruiz García 2006: 120144, Santiago 1999). In Samuel Ruiz's words, “we [the diocese] received very important support from outside the country, and that allowed us to walk toward the construction of the peace dialogue. That is why we cannot say that it was an individual mediation [by the diocese], but a collective mediation, in which the diocese participated" (2006: 136).

\section{The Consolidation: Agroecology, Food Security, and the Zapatista Project}

During the few years following the Zapatista uprising, DESMI concentrated most of its projects on supporting the refugees that had been displaced by military and paramilitary violence in the region (DESMI 2009). Importantly, during this period the 
Zapatista movement, and all the organizations working with it, became immersed in a rich, dynamic dialogue with thousands of activists, civil society organizations, and social movements from across Mexico and around the world (Ronfeldt et al. 1998, Rosset et al. 2005). In these encounters between the indigenous movement and civil society, concepts such as indigenous rights, indigenous autonomy, feminism, and food sovereignty were debated and imbued with a Zapatista meaning (Klein 2015: 217-286, Naylor 2014: 160, Ronfeldt et al. 1998, Starr et al. 2011). These were also the years when many new solidarity networks were created in support of the EZLN, in addition to those that had been built during its clandestine years (Barmeyer 2009, Klein 2015). DESMI's solidarity economy project was now supported by a stronger and highly diversified international network of solidarity groups and social movements. Julia, who worked at DESMI between 1997 and 2008, and now is part of the organization's board of external consultants, refers to this process and the core role that international donor agencies have played in the development of DESMI's project:

Since the first years of DESMI, we have collaborated with several international donor agencies that have helped us to fund our projects. For instance, the revolving loan fund was created with the support of Entraide et Fraternité from Belgium. Catholic Relief Services and Oxfam [from the U.K.] have been there since the beginning too; and many of our food security projects have received the support of Bread for the World [a German organization] and IDEX [now Thousand Currents, a San Francisco-based NGO]. We were not working alone. Nevertheless, it was a surprise for us to see how many people supported the 
EZLN. We never imagined this reaction from civil society, never. Suddenly, we had all these people, organizations, and social movements that began to collaborate with the EZ[LN], and many of those projects complemented, or reinforced, our program of solidarity economy. We had similar ideas and were working toward common objectives. A good example is the market for Zapatista organic coffee in Europe, which is essentially a network of solidarity organizations. It would not exist without those activists and organizations who are also working to build alternative economies in their own countries. As the EZ[LN] said in La Sexta [The Other Campaign]: each group first works to transform its own context, and then we can come together and collaborate to create something bigger. ${ }^{16}$

However, as Barmeyer points out, simultaneous to this evolving encounter with global civil society, the EZLN was dealing with the exhaustion of its communities after years of clandestine organizing followed by the armed conflict, the failure of the peace dialogue with the Mexican government, the scaling-up of the low-intensity war, and then, since 1996, the impacts of Zapatista resistance policies - that is, the rejection of any funding or services from the government (Barmeyer 2009: 109-135, Klein 2015, Zaga 2015). The situation was particularly difficult for those communities that had been displaced by military and paramilitary violence (UN 2012, Wild 1998). As I discussed in Chapter 3, the reorganization of the EZLN in 2003 - and particularly the articulation of a development project focused on education, health, agroecology, and a solidarity economy—sought to address these issues (EZLN 2003). According to Barmeyer, this 
reorganization also aimed to counteract the movement's dependence on foreign resources, which was quickly deepening after the implementation of resistance policies. Since 2003, all projects and resources coming from civil society have been coordinated by the Juntas de Buen Gobierno (JBG) and used to strengthen the autonomy of Zapatista communities (Barmeyer 2009: 17-18, Zaga 2015).

Elena, the current director of DESMI and a staff member since 1993, refers to this transition while explaining the objectives that led the EZLN to adopt an agenda of agroecology:

In the context of the war, with the increasing militarization of the region and the displacement of entire communities, it became a top priority for the movement [EZLN] to attain communities' food security. There was also the idea that a better diet would help to prevent many of the diseases these communities were suffering from. In that moment, we [DESMI] did not know all the impacts that agrochemicals have on ecosystems and people's health, but we had a better understanding of how they contribute to the degradation of soils and the pollution of water bodies... We needed to give priority to the production of food, but we had to learn how to do that while preserving the environment. There was also the issue of health. You know that before the movement these communities lacked any kind of health services, and there was the idea that health means having access to medicines and doctors. We had to shift our focus from a "solution" or "remedy" perspective to the practical prevention of diseases. Improving these communities' diets was one way, but it was not enough. We needed to promote 
deeper changes in our agricultural practices and the ways we understand and relate to the environment. All that came together in the projects of agroecology, health, and education. ${ }^{17}$

Elena further explains how the reorganization of the EZLN has changed the ways DESMI works with these communities. These changes are a good reflection of how Zapatista communities conceptualize their autonomy:

We [DESMI] created the agroecology, agro-forestry, and ethno-veterinary areas, and the movement [EZLN] organized its committees of agroecology, one per Caracol. Each committee is made of trainers and promoters who are chosen by their communities. For instance, in Oventic, there are 34 trainers and 274 promoters - 240 men and 34 women; in Roberto Barrios we are working with 60 promoters. Instead of working with individual communities, as we did before, we now work with the committees of agroecology and coordinate our projects with the Juntas de Buen Gobierno.

I think that this is a good structure because it reinforces the autonomy of these communities and promotes the development and exchange of knowledge among peasants, what is now called the peasant-to-peasant methodology. The challenge is to avoid vertical structures of power and make sure that all the information and projects reach the communities. Obviously, not all communities are on the same level [of organization]. Some of them work better than others, and that also depends on their promoters. We can see how trainers are doing their work, and most of them are truly committed to this [agroecological] project, but it 
is more difficult for us to follow the promoters and see what is happening in all communities because we are not working directly with them anymore.

Communities need to take the responsibility to supervise their promoters and change them if they are not working well. That is part of their autonomy now. ${ }^{18}$ To what extent has DESMI's solidarity economy project influenced and contributed to the actual practice of Zapatista indigenous autonomy? One way to address this question is to highlight three facts. First, the EZLN has adopted a solidarity economy model as one of the key axes of its development program. Indeed, as Table 10 shows, the collectivization of production and the creation of cooperatives (including women-only collectives and cooperatives), the prioritization of food production over cash crops, and the participation of cooperatives in alternative markets (the solidarity market for Zapatista organic coffee, honey, and crafts) are the foundations of the Zapatista economic model. Second, most of the projects that DESMI once helped to create and organize in those communities (mainly collectives and cooperatives) are still alive. Even if they have transmuted into new projects, the collectivization of production and the idea that community economies should be based on solidarity rather than on principles of individual profit are inherent to the Zapatista project. Third, all of these projects are now autonomous from DESMI. Currently, the role of DESMI—and all the international organizations and donor agencies it works with-in Zapatista communities is mainly limited to two areas: developing of social capital through training the local committees of agroecology, and coordinating the relationships between community cooperatives and international solidarity markets (mainly the coffee market). Taking into account these 
elements, it is clear that Zapatista autonomy is deeply rooted in the solidarity economy project that began in the 1970s with the help of DESMI and the diocese.

\section{Raising an Environmental Consciousness}

But how did this consciousness about environmental issues emerge in the first place? In other words, where does DESMI's model of agroecology come from?

Sebastian, who has been part of DESMI since 1974-first as its director for 34 years, and then as a member of its external consultant board — delved into these issues during our final interview. He recounted DESMI's decades of work with these communities and how food security and environmental issues became a priority for the organization. Although extensive, it is worth giving space to this interview because Sebastian's voice illustrates how DESMI perceives its own work and trajectory:

After some years of having worked with these communities, we became aware that the soils were eroded and that the system of quema y tala [slash-and-burn] had contributed to the deforestation of the region. In addition, in order to survive, peasants were selling wood and charcoal. They were destroying their forests. We also had the problem that crop yields were very low and the milpas were not producing enough maize. We quickly understood that it was the main reason people migrated: to complement the maize [crop] for the year. We realized that if people had enough food and could live from their land, they would prefer to remain in their communities. It was particularly true in that moment because the communities were not as dependent on cash as they are today.

With these problems in mind, in the 1980s we [DESMI, together with 
other local organizations] started experimenting with different techniques to improve agricultural production while reducing communities' dependency on agrochemicals. It was called "integrated systems." We were not thinking only about the environment. Rather, it was more about reducing the costs of production, because peasants spent a lot of money to buy agrochemicals, and they frequently had to borrow that money. So, we thought that if peasants reduced their use of agrochemicals they would reduce their indebtedness. We also emphasized projects that were focused on producing food and not only cash crops - mainly coffee — or livestock. In fact, many of the loans from the revolving fund that were used in coffee cooperatives, were limited to collectives that were also working to improve their food systems. ${ }^{19}$

The transition from an agricultural system based on agrochemicals to the adoption of organic and agroecological methods of production has not been smooth, and some communities still resist these changes. Elena recognizes that "we have not achieved our goal to make sure that all the communities we work with adopt the agroecological model. The main reason why peasants resist this change is because of the extra work behind organic production. Nevertheless, there are some successful experiences that allow us to think that this model is viable. For instance, some of the households that have adopted agroecological methods in their milpas are now able to produce maize for the whole year. ${ }^{20}$ However, Sebastian notes, beyond the extra work that organic production requires, there is also the ideal, according to the model of industrial agriculture, of a "successful farmer." These communities are not immune from that idealization: 
People used to believe that producing "naturally" [without agrochemicals] was only for the poorest - agroecology and organic are new concepts, we used to say "natural." For peasants in these communities agrochemicals meant progress, and that was an idea that came from the government. It has been very difficult to reverse this idea. Even today, progress is understood in relation to the model of industrial agriculture: having better yields, producing for the market, introducing machines, and having trucks - these ideas remain there. Even if peasants produce for alternative markets, they still have that "successful" model in their minds. ${ }^{21}$ In addition to the objective of weakening peasants' dependence on agrochemicals in order to reduce their production costs, there was another element that strongly influenced the introduction of organic methods of production in the region: the development of an international fair-trade and organic coffee market. This issue brings into the discussion the role that alternative solidarity markets might play in the definition of agricultural practices. As Sebastian notes, the emergence of an international solidarity market for fair trade and organic coffee was a key impetus for the widespread adoption of organic methods of production in the region. This development highlights the important role that consumers in the global North can play in building solidarity networks if they choose to support alternative economies that prioritize social and environmental justice over the principles of accumulation, exponential growth, overconsumption, and profits. Sebastian elaborates:

Parallel to the widespread introduction of agrochemicals in the region, a new market for organic coffee was emerging, and that helped a lot! Peasants started to 
think differently about agrochemicals because they saw that producing organically had more value in the market. It implied more work but communities were willing to invest in coffee. It was also useful for our project because communities needed to organize in regional cooperatives and work together with the agencies that were buying their coffee. For instance, communities had to keep their commitment to produce organically throughout the year because they had received pre-harvest payments. Clearly, the production of coffee and the organization of cooperatives reduced the time peasants invested in their milpas, and they continued to use agrochemicals there. But it was a good starting point. Coffee was a good example that producing organically beyond subsistence needs was possible. ${ }^{22}$

Although the adoption of organic coffee did not imply the direct transfer of organic methods to the milpa - and even reinforced the use of agrochemicals there in order to save time and labor that could be used in the coffee plots and in organizing cooperatives - it did stimulate experimentation with organic methods in other areas of food production, such as organic vegetable and herb gardens.

One valuable and unexpected outcome of this process was that the organization of collective gardens, which were located within villages, favored the participation and training of women in the production of food. According to the prevalent gendered division of labor in these communities, women are responsible for most of the work within communities, while men work outside, either in the milpa and coffee plots or in nearby plantations or towns. Traditionally, men have the responsibility for supplying 
food to their families. The introduction of these collective gardens slightly altered that equation and represented a good starting point for training women and collectivizing their work. Even if the milpa continued to represent the primary source of food for these families, women acquired a more active role in the process of producing food. The organic vegetable gardens were then followed by the organization of women-only breadbaking and small-livestock-raising cooperatives - in addition to craft and grocery store cooperatives (see Table 10). In other words, the introduction of organic coffee had several unexpected side effects in these communities. Sebastian describes this process:

In order to complement the milpa, we began to work with women to develop collective organic vegetable gardens and bread-baking and chicken-raising cooperatives. These projects have been very successful. Despite all the difficulties women faced to participating in any activity other than housework, they were eager to learn new things. Indeed, in the long term, these projects were useful to reinforce some ideas about women's rights and gender equality. These are also new terms; we used to say “women's participation.” Many times these projects did not work at the beginning, but then, after a while, communities tried again. Currently, almost all communities have women-only collective bakeries, organic vegetable gardens, and artisan and grocery cooperatives. The seed was sown, waiting for better conditions to germinate.

By the time we created the agroecology and ethno-veterinary groups [in 2000], we had a long path behind us, and we need to recognize that it has been a process full of mistakes. For instance, when we created the revolving fund, we 
gave some loans to buy agrochemicals, particularly to those collectives that were producing surpluses for the market. We also believed that investing in livestock was a good idea, and we supported some groups who wanted to create livestockraising cooperatives. Some collectives even borrowed money to buy a truck. But we learned a lot from those mistakes. Both the communities and DESMI, we had to learn together and try different things. This consciousness about the environment did not exist as such. We walked by following our intuition, and it has taken a long time to get here. We did not have all the knowledge that we have today; and you can see, now we have to deal with other problems that surpass our current capacities, such as climate change. We are always a little behind what is needed, but that is a part of the process of building something different, something better, is it not? ? $^{23}$

As these quotes emphasize, DESMI's journey has not been linear or free of contradictions. Throughout this process, DESMI staff has had to learn on a daily basis, together with these indigenous peasants, how to cope with some of the most demanding problems and limitations their communities face. However, Sebastian notes, "to develop the capacities to reflect about your reality, recognize what does not work, and attempt to create something better that benefits the most people is the ultimate goal of this project. Sometimes those changes will be millimetric, almost imperceptible, limited to raising a new consciousness about some problems. Many other times you will fail, but what is important is to learn from those mistakes and try to do something different, something better." 24 


\section{Once Again: DESMI, the Pastoral of Mother Earth, and Seed Sovereignty in Non-Zapatista Communities}

Another element that reflects the reach of DESMI's solidarity economy project is the work that it has been developing in non-Zapatista communities since 2011 (see Tables 10 and 12). Similar to the 1970s, in the context of the Indigenous Congress of 1974, DESMI has joined its efforts with the diocese's new project of political organization. This time the objective, in the words of the diocese, is "to organize the defense of the territory and natural resources against the neoliberal agenda of dispossessions that affects the region": mining, dams, highways, agribusiness and GMOs, international carbon markets, and drug and migrant trafficking (Diocesis 2014, Lerna Rodríguez 2015: 80). With this objective in mind, the diocese announced the organization of the Congress of Mother Earth, which would take place on January 2014-to commemorate both the $40^{\text {th }}$ anniversary of the Indigenous Congress of 1974 and the third anniversary of Samuel Ruiz's death (Lerna Rodríguez 2015).

DESMI, together with other organizations created by Samuel Ruiz during his administration, participated in the Congress and helped the pastoral-since 2011 called the Pastoral of Mother Earth— to develop four work agendas: spirituality and ecology, context analysis, legal and organizational support, and agroecology and food sovereignty, with DESMI taking responsibility for the latter ${ }^{25}$ (GAP 2015). According to Mariano, a DESMI staff member, "the purpose of this work is to support parishes in their process of political organizing and help them to implement at the community level some of the projects that were defined during the Congress. ${ }^{26}$ DESMI's seed sovereignty workshop 
in San Andrés, which I described in Chapter 4, is one example of this kind of collaboration. The Guardians of Mother Earth and Seeds project, which I will present and discuss in the following chapter, is another.

After an invitation from Elena-DESMI's director-I was able to attend four meetings with members of the pastoral from the region of Los Altos. One issue that came out repeatedly during those meetings - and was reiterated in several of my conversations with pastoral members - was the need to promote and support the political organizing of non-Zapatista communities and, if possible, to create spaces where Zapatistas and nonZapatistas can interact. One example of this is the regional meetings where the EZLN informs non-Zapatista communities about specific neoliberal threats that might affect all communities in the region. These meetings are jointly organized by the parishes and the EZLN. At the time of my fieldwork, all of the regions of the diocese had held at least one such encounter. ${ }^{27}$ Pedro, a Tsotsil member of the parish of Chenalhó, discusses how some members of the pastoral understand this political objective: "We are working on creating bonds of solidarity between Zapatista and non-Zapatista communities. We are part of the diocese but our heart is also with the movement [the EZLN] because we all share the same dreams....each community has its own problems, but what unifies all of us is the necessity of defending our Mother Earth against the neoliberal agenda that seeks to destroy all we are as Mayan peoples." 28

According to Luis, a member of the Cideci, the Congress of Mother Earth has favored a new encounter between the pastoral and the EZLN around environmental issues and the defense of the territory: 
What is happening in the context of the diocesan Congress of Mother Earth is the confluence of two actors who have great influence in the region: the pastoral and the EZLN. What unifies them is the defense of the territory and natural resources. Behind this proposition, there is a confluence of ideas: from the EZLN, the geopolitical defense of the territory and the proposition of an agroecological model; and from the diocese and the Indian Theology, the sacredness of Mother Earth...This is only the beginning but, if the EZ[LN] and the pastoral are able to work together, we would be talking about the emergence of a new social subject in the region...The main challenge is to overcome the political division that exists in non-Zapatista communities. However, the pastoral has a huge strength: nobody in this region, even the government, reaches so many communities and people as the diocese does. The diocese has access to every community in the region. The pastoral has to take advantage of that situation. ${ }^{29}$

Luis is correct that the diocese has an institutional capacity that gives it a unique opportunity to advance this agenda against neoliberal dispossession. As Figure 11 shows, the diocese covers 48 percent of the territory of Chiapas - which coincides almost exactly with the area of the Zapatista conflict (see Chapter 3). About 76 percent of the population in the region is Catholic. This means that the diocese encompasses almost 1.4 million people from 2,500 communities, 63 percent of whom are indigenous people from the Tseltal, Tstosil, Ch'ol, Chab, and Tojolabal ethnic groups. The pastoral alone has 8,418 active members (98 priests, 320 deacons, and 8,000 catechists) who are dispersed across 57 parishes (CH 2017, Diócesis 2013). 
Taking into account these data, the regional process of political articulation put in motion by the Pastoral of Mother Earth is significant. New spaces for dialogue and collaboration among different actors have emerged since the 2014 Congress of Mother Earth. The strength of this process lies, as Luis suggests, in having articulated a common agenda around environmental issues and the defense of the territory. The Congress's closing declaration states: "We have realized that the capitalist system, with its neoliberal, patriarchal, and repressive institutions and practices is not almighty; only God is...In opposition to the transnational corporations and their accomplice governments who seek to grab our territories and their natural resources, which are a gift from God to our communities, we need to have the courage to say to them: Stop, brothers, this is God's land!" (Diocesis 2014). As I will discuss in the following chapter, the defense of native maize — and underlying it, seed sovereignty—is one of the key foci shaping this countermovement.

The Congress of Mother Earth also created an opportunity for DESMI to collaborate with non-Zapatista communities and to extend its solidarity economy project beyond Zapatista territory. The Guardians of Mother Earth and Seeds project, which links the defense of the territory with seed sovereignty, is one of several initiatives DESMI has engaged in since 2011. It is worth asking whether these projects in non-Zapatista communities might contribute - and to what extent — to reinforcing the Zapatista project of indigenous autonomy. 


\section{Conclusion}

For Zapatista communities, seed sovereignty is not the starting point of their decommodification project. Rather, seed sovereignty reinforces a long-term process of decommodification that began in the mid-1970s with the adoption of a solidarity economy model. This process has been complemented by the progressive appropriation of both the territory and the agricultural production system. This appropriation encompasses multiple sub-processes, all in different stages of development: the occupation and military defense of the territory by the EZLN; the prioritization of communities' food security over production for the market; the reconceptualization by communities of natural resources and ecosystems beyond utilitarian principles; the adoption of agroecology as the axis of the Zapatista agricultural model; and the incorporation of Zapatista communities into alternative markets that are rooted in international solidarity networks. The Zapatista model of seed sovereignty is a synthesis of this process of decommodification. If this model were able to transcend the relatively favorable Zapatista context, it could potentially be a catalyst for other decommodification processes in non-Zapatista communities. I suggest that what makes this transition from Zapatista communities to non-Zapatista communities possible is the relevance that native seeds have for peasant communities in Chiapas and the politicization that already exists around Mayan identity and native maize. 
Table 11. Key Events in the Development of DESMI and the EZLN: 1968-2017

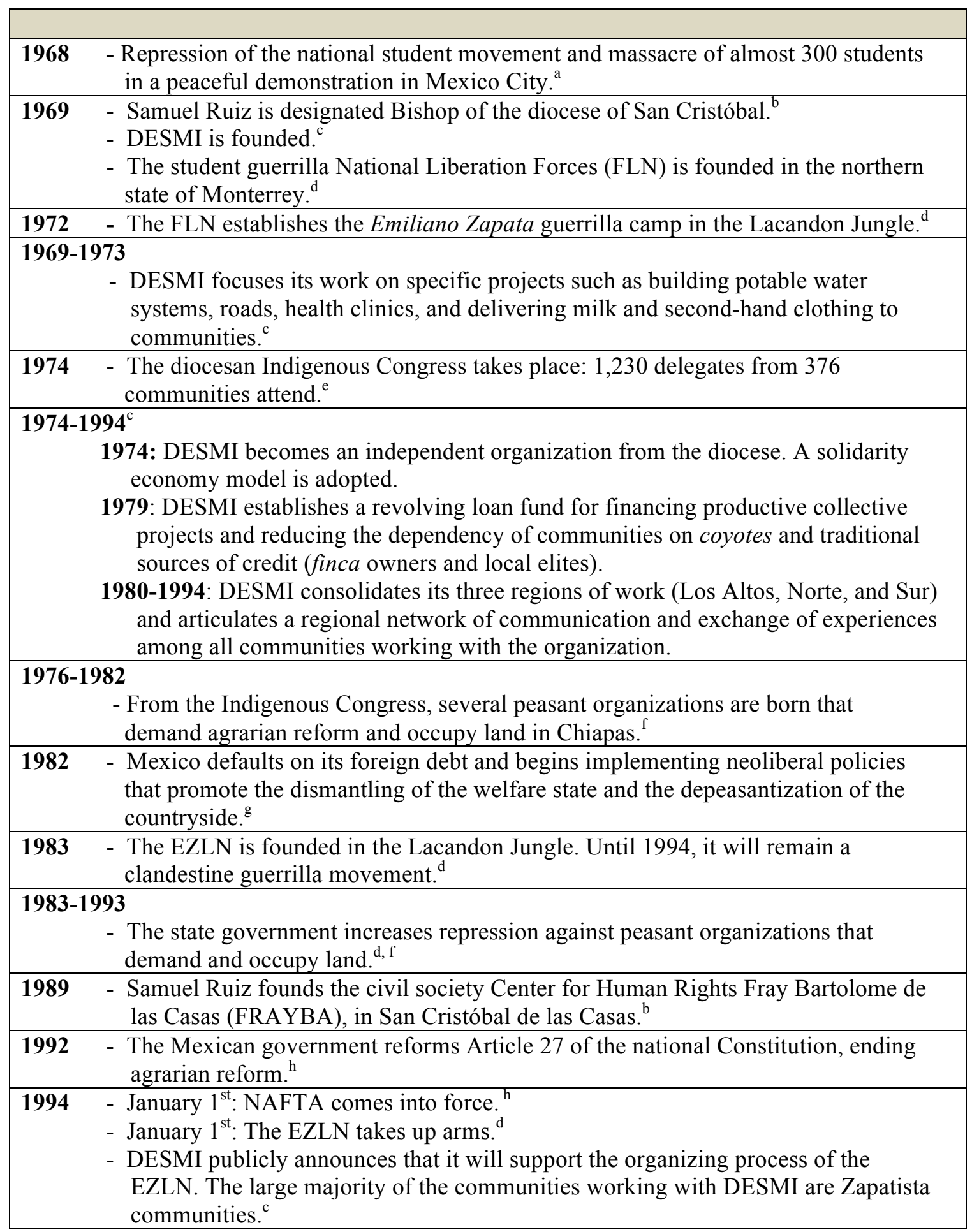


1994-2001

1994-1997: Peace negotiations between the EZLN and the Mexican government begin. The diocese, under Samuel Ruiz, is the key mediator in the dialogue. ${ }^{\mathrm{b}}$

1994-1998: Several peasant organizations not affiliated with the EZLN occupy finca lands. ${ }^{\mathrm{i}}$

- Samuel Ruiz promotes the creation of several civil society organizations supporting the EZLN and the peace dialogue: CORECO, SIPAZ, SERAPAZ, and INESIN. ${ }^{\mathrm{b}}$

1996: The San Andrés Accords are signed by both the EZLN and the Mexican government. $^{\mathrm{j}}$

- The National Indigenous Congress, representing indigenous groups from across the country, is founded in support of the Zapatista movement and the ratification of the San Andrés Accords. ${ }^{1}$

- The EZLN organizes the Intergalactic Encounter for Humanity and Against Neoliberalism in Zapatista territory; more than 3,000 people from 40 countries attend. ${ }^{\mathrm{k}}$

1996-2000: The government intensifies the low-intensity war against the EZLN; it is estimated that one third of the Mexican military, about 70,000 soldiers, are stationed in Chiapas alone. The number of displaced people reaches between 50,000 and $90,000 .^{\mathrm{j}}$

1997: The paramilitary group Paz y Justicia massacres 45 Tsotsil indigenous woman and children from Las Abejas, a pacifist group supporting the EZLN in Acteal, Chiapas. The peace dialogue is broken after the massacre. ${ }^{j}$

1999: The government establishes the Agrarian Accords and grants titles to 240,000 hectares that had been occupied after the Zapatista uprising. The EZLN does not participate in these accords. ${ }^{\mathrm{i}}$

2001: The EZLN organizes the March of the Color of Earth, from Chiapas to Mexico City, and attends the Federal Congress to demand ratification of the San Andrés Accords.

- The Federal Congress unilaterally approves a federal law on indigenous rights that does not correspond to the San Andrés Accords; the EZLN repudiates the law. ${ }^{\mathrm{j}, \mathrm{k}}$

1994-1999 DESMI concentrates most of its work on the articulation of regional projects to support refugee communities. ${ }^{c}$

1996 - The international peasant movement La Vía Campesina (founded in 1993) launches the concept of food sovereignty.

2000-2011

- DESMI incorporates into its agenda the topics of food sovereignty and sustainable development, and creates the areas of agroecology and ethno-veterinary. ${ }^{\mathrm{c}}$

2002 - The EZLN launches the anti-GMO corn campaign Semillas Madre en Resistencia. ${ }^{\mathrm{n}}$

2003 - The EZLN reorganizes its government structures and creates the five Caracoles and Juntas de Buen Gobierno, which represent 27 autonomous municipalities. The movement also establishes a development program encompassing health, education, agroecology, and solidarity economy, and reorganizes its solidarity networks around its autonomous development project. ${ }^{\mathrm{m}}$ 


\begin{tabular}{|c|c|}
\hline 2006 & $\begin{array}{l}\text { - The EZLN launches La Otra Campaña ("The Other Campaign") and promotes the } \\
\text { autonomous organization of resistance against the neoliberal model; in response, } \\
\text { hundreds of civil society initiatives are organized in Mexico and other countries, } \\
\text { calling themselves Adherents to The Other Campaign. } \\
\text { - The Mexican government launches the War on Drugs, sharply increasing the } \\
\text { militarization of the country and coordinating a security agenda with the U.S. (in } \\
\text { 2016, it is estimated that more than } 100,000 \text { people have been assassinated and } \\
30,000 \text { missing in the ten years of the drug war). }\end{array}$ \\
\hline 2007 & $\begin{array}{l}\text { - The national food sovereignty and anti-GMO corn campaign Sin Maíz No Hay País } \\
\text { is launched. More than } 300 \text { civil society organizations and social movements join } \\
\text { it. }{ }^{\text {n }}\end{array}$ \\
\hline 2011 & $\begin{array}{l}\text { - Samuel Ruiz dies. } \\
\text { - The diocese begins to organize the Congress of Mother Earth. } \\
\text { - More than 15,000 Mayan beekeepers from the Yucatan Peninsula form the anti- } \\
\text { GMO coalition MAOGM. }\end{array}$ \\
\hline 2012-2 & $\begin{array}{l}013 \\
\text { - Four pre-congresses take place in the different regions of the diocese, aiming to } \\
\text { identify and propose solutions to the problems communities experience. }\end{array}$ \\
\hline 2012 & $\begin{array}{l}\text { - The EZLN organizes the March of Silence; more than 40,000 Zapatistas march on } \\
\text { five cities in Chiapas. }\end{array}$ \\
\hline 2013 & $\begin{array}{l}\text { - The EZLN organizes the La Escuelita (Little School) campaign. It invites civil } \\
\text { society members from all around the globe to visit Zapatista territory and learn } \\
\text { about the Zapatista model of development; more than 2,000 people attend. }\end{array}$ \\
\hline 2012-2 & $\begin{array}{l}017 \\
\text { - DESMI incorporates into its project the topic of the defense of the territory and } \\
\text { natural resources. In the framework of the Congress of Mother Earth, DESMI } \\
\text { coordinates an agenda for working with non-Zapatista communities in the region; } \\
\text { some of them are adherents to The Other Campaign. }\end{array}$ \\
\hline 2014 & $\begin{array}{l}\text { - The Congress of Mother Earth takes place in San Cristóbal de las Casas: more than } \\
1,000 \text { delegates attend. Eight topics are discussed. }{ }^{30} \text { Among the several statements } \\
\text { announced in the closing declaration are the defense of native maize and the } \\
\text { opposition to transgenic crops. }\end{array}$ \\
\hline 2015 & $\begin{array}{l}\text { - Pope Francis publishes the Encyclical Letter Laudato Si": On Care for Our Common } \\
\text { Home. } \\
\text { - The EZLN organizes the international seminar "Critical Thinking Against the } \\
\text { Capitalist Hydra" in the Cideci-Unitierra; more than 1,000 people attend. }{ }^{\mathrm{q}} \\
\text { - Following up on the Congress of Mother Earth, DESMI organizes the Guardians of } \\
\text { Mother Earth and Seeds project. }\end{array}$ \\
\hline 2017 & $\begin{array}{l}\text { - The National Indigenous Congress and the EZLN launch a female indigenous } \\
\text { candidate in the national presidential elections of 2018: María de Jesús Patricio. }\end{array}$ \\
\hline
\end{tabular}

Source: Author's elaboration, based on: a. (Poniatowska 1971); b. (Ruiz García 2006, Santiago 1999, 2016a, 2016b); c. (DESMI 2001, 2009); d. (Cedillo 2010, 2008); e. (Diocesis 2014, Lerna Rodríguez 2015); f. (Aubry 2004, Harvey 1998); g. (Harvey 2005); h. (Bello 2009, de Ita 2006); i. (van der Haar 2007, Villafuerte Solís et al. 1999); j. (Aubry and Angelica 1998, Klein 2015, Le Bot 1997, UN 2012, Wild 1998, Zaga 2015); k. (Barmeyer 2009, Klein 2015); 1. (CNI 1996); m. (EZLN 2003); n. (Brown 2013, Sin Maíz No Hay País 2008, Tamariz 2013); o. (EZLN 2005a); p. (Aragón 2012, Koman Ilel 2012); q. (EZLN 2015); r. (Henríquez 2017); s. (CBSNews 2016, Roberts 2017) 


\section{CHAPTER SIX}

\section{BUILDING SEED SOVEREIGNTY:}

\section{THE GUARDIANS OF MOTHER EARTH AND SEEDS PROJECT}

In this chapter, I analyze in depth some of the potential decommodification elements of DESMI's project of seed and food sovereignty in non-Zapatista communities. As I will discuss, this project of decommodification goes far beyond the idea of preventing the enclosure of seeds and is better understood as a process aiming to expand the commons. The latent power of DESMI's Guardians of Mother Earth and Seeds project lies in its capacity to embrace this process of decommodification beyond the conditions of the Zapatista context.

By the time DESMI launched the Guardians of Mother Earth and Seeds project in August 2015, the organization had already been working with these 25 indigenous and mestizo non-Zapatista communities - which I introduced in Chapter 3 - for a few years.

Table 12 focuses on the 25 communities that participate in this project, and Figure 12 shows the geographical distribution of these communities.

As can be noted in Table 10 in Chapter 5, the projects developed in non-Zapatista communities are largely similar to those in Zapatista communities. There are two main differences: the diversification in number, type, and objectives of these projects, and the institutional networks in which they are embedded. Solidarity economy projects in Zapatista communities are part of the EZLN's broader and more comprehensive agenda of indigenous autonomy and have a whole set of institutions supporting them and 
reinforcing the collectivization of productive practices - a collectivization that is materialized in the creation of collectives and cooperatives of production at the community and regional levels (see Table 10, and Chapter 3). Non-Zapatista communities, in contrast, entirely lack this socio-political and institutional framework. However, most of these communities do benefit from the support of the diocese for their political organizing and from government subsidies. The exceptions are the two mestizo communities that are adherents to the pro-Zapatista The Other Campaign, both of which are involved in land conflicts and have partially adopted Zapatista resistance policies (see Table 12).

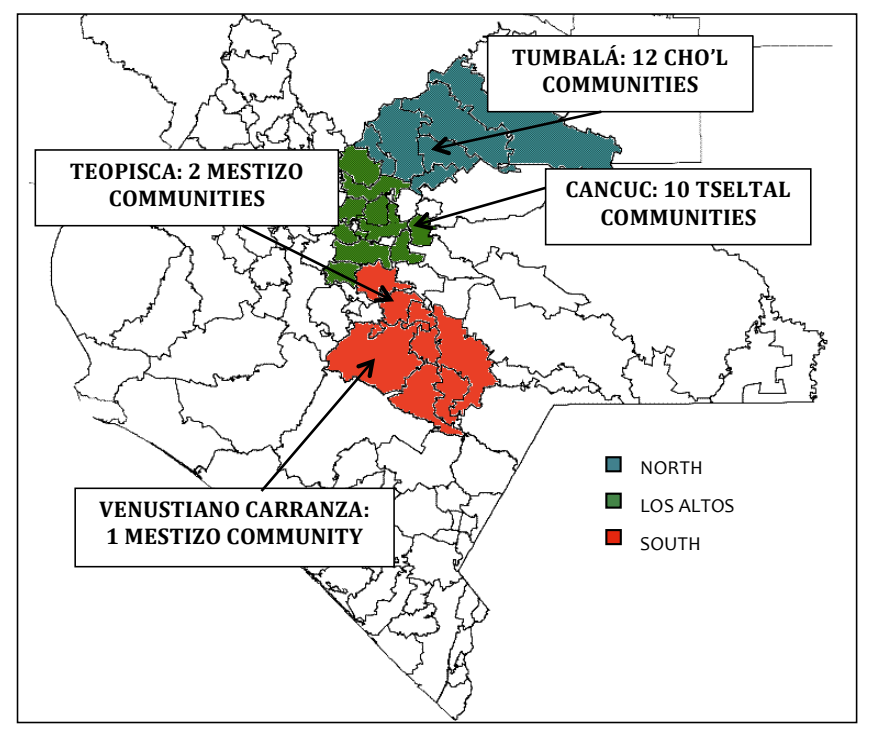

Figure 12. Communities participating in DESMI's Guardians of Mother Earth and Seeds project. Author's elaboration based on DESMI's internal documents.

The Guardians of Mother Earth and Seeds project is DESMI's first attempt to articulate a regional agenda among non-Zapatista communities. These 25 communities were invited because they had successfully maintained their collectives for more than two years; which, according to Elena, DESMI's director, is a basic measure of their 
commitment and organizing skills to implement and sustain collective projects.

Although this is a regional project, DESMI works with these 25 communities in five different groups, mainly because of the difficulties peasants have in traveling to distant places. Despite working independently from each other, all of these groups share a common agenda with specific goals and know what the other groups are doing. At the end of my fieldwork, in March 2016, DESMI was considering the possibility of incorporating some other communities into the project. Meanwhile, introductory seed sovereignty workshops had been presented in several of those potential new member communities (the workshop in San Andrés, which I described in Chapter 4, is one example).

Table 12. DESMI's Projects in Non-Zapatista Communities Participating in the Guardians of Mother Earth and Seeds Project

\begin{tabular}{|c|c|c|}
\hline Key actors & $\begin{array}{l}\text { Sub-group and key } \\
\text { characteristics }\end{array}$ & DESMI's Projects \\
\hline \multirow[t]{2}{*}{ Diocese } & $\begin{array}{l}\text { GROUP 1: } 10 \text { Tseltal } \\
\text { communities from the parish of } \\
\text { Cancúc. } \\
\text { Receive government subsidies } \\
\text { Most of the work is developed } \\
\text { with men }\end{array}$ & $\begin{array}{l}\text { - } \text { Context analysis workshops } \\
\text { - Organic coffee production and } \\
\text { - } \text { Alternative certification programs } \\
\text { - Seed sovereignty }\end{array}$ \\
\hline & $\begin{array}{l}\text { GROUP 2: } 12 \mathrm{Ch} \text { 'ol } \\
\text { communities from the parish of } \\
\text { Tumbalá. } \\
\text { Receive government subsidies } \\
\text { Most of the work is developed } \\
\text { with women }\end{array}$ & $\begin{array}{l}\text { - Firewood saving stoves and dry } \\
\text { latrines } \\
\text { - Training in agroecology, organic } \\
\text { vegetable gardens, and food security } \\
\text { - Seed sovereignty }\end{array}$ \\
\hline
\end{tabular}




\begin{tabular}{|c|c|c|}
\hline \multirow[t]{2}{*}{$\begin{array}{l}\text { Adherents to } \\
\text { The Other } \\
\text { Campaign }\end{array}$} & $\begin{array}{l}\text { GROUP 3: One mestizo } \\
\text { community from Venustiano } \\
\text { Carranza. } \\
\text { This community is involved in } \\
\text { land conflicts with paramilitary } \\
\text { groups. In } 2012 \text { it joined The } \\
\text { Other Campaign. } \\
\text { Resistance policies (the } \\
\text { rejection of services and } \\
\text { subsides from the government) } \\
\text { DESMI works with both } \\
\text { women and men }\end{array}$ & $\begin{array}{l}\text { Firewood saving stoves, dry latrines, } \\
\text { potable water, and rainwater } \\
\text { collection systems } \\
\text { - Chicken-raising cooperative } \\
\text { (women) } \\
\text { - Mushrooms and molasses-production } \\
\text { collectives (men) } \\
\text { - Training in agroecology and food } \\
\text { security } \\
\text { - Seed sovereignty }\end{array}$ \\
\hline & $\begin{array}{l}\text { GROUP 4: One mestizo } \\
\text { community from Teopisca. } \\
\text { This community was created } \\
\text { after the occupation of a finca } \\
\text { in } 1995 \text { and joined The Other } \\
\text { Campaign in } 2006 . \\
\text { Resistance policies } \\
\text { Most of the work is developed } \\
\text { with women }\end{array}$ & $\begin{array}{l}\text { Firewood saving stoves, dry latrines, } \\
\text { and water well } \\
\text { - Chicken-raising, bread-baking, herb- } \\
\text { based remedy cooperatives } \\
\text { - Collective organic vegetable and } \\
\text { herb gardens } \\
\text { - Training in agroecology and food } \\
\text { security } \\
\text { - Seed sovereignty }\end{array}$ \\
\hline $\begin{array}{c}\text { Other non- } \\
\text { Zapatista } \\
\text { communities }\end{array}$ & $\begin{array}{l}\text { GROUP 5: Four mestizo } \\
\text { families from one community in } \\
\text { Teopisca whose head of } \\
\text { household are women. } \\
\text { Receive government subsidies } \\
\text { Collaborate with other } \\
\text { organizations focused on } \\
\text { women's rights; also participate } \\
\text { in the organic farmers market in } \\
\text { San Cristóbal de las Casas. }\end{array}$ & $\begin{array}{l}\text { - } \text { Firewood saving stoves and dry } \\
\text { latrines } \\
\text { - } \quad \text { Chicken-raising collective } \\
\text { - } \quad \text { Organic vegetable garden } \\
\text { - } \quad \text { Training in agroecology and food } \\
\text { - } \quad \text { Security } \\
\text { Seed sovereignty }\end{array}$ \\
\hline
\end{tabular}

Source: Author's elaboration based on DESMI's internal documents and fieldwork. 


\section{Fencing off Non-Market Spheres From Market Encroachments: Understanding Informal Seed Systems as Commons}

The point of departure of DESMI's seed sovereignty project was raising awareness about the fundamental importance that native seeds have for the social reproduction of these peasant communities. The organization emphasized the relationship between native seeds and food security. In order to achieve this goal, DESMI conducted a series of introductory workshops in which community members discussed four questions: (1) What is the role of native seeds in their lives? (2) How do seed regulations and the introduction of GMOs affect native seeds and subsistence agriculture? (3) Are seeds part of these communities' commons? and (4) How can communities protect their seeds from external threats?

Although the responses to these questions might seem self-evident, this was not the case. In addition to the scarce (or non-existent) information these communities had regarding federal laws on seeds, there was also a set of conceptual and cognitive issues that blurred what might seem to be a straightforward analysis. Indeed, it was a clear understanding of seeds as commons that was missing in the first place (see Ostrom (1990) for a discussion about how the distinct characteristics of a particular natural resource influence its conceptualization as part of the commons, and Brush (2005) and Kloppenburg (2004) for an analysis on seeds).

The lack of an understanding of native seeds as commons can be explained by two factors. First, most peasants in these communities conceive of seeds as something that can be reproduced endlessly through individual agricultural practices, and thus are not 
finite. In other words, although communities' seed systems are the outcome of all the agricultural practices performed by their members, peasants may take for granted their individual capacity to reproduce their own seeds. Second, seeds and crop genetic resources are still conceived of by these communities as a universal commons, which can be translated into the idea that nobody owns the seeds and everyone has the right to access them for producing their own food. "These seeds come from Mother Earth; everyone can use them,"' says Rosa, a Ch'ol woman from Tumbalá. Josefa, a mestiza woman from Teopisca, concurs: "Seeds are there for people and animals to use them; even plants need their seeds to reproduce. Seeds are for everyone."2

As I discussed in Chapters 1 and 4, this conceptualization is not exclusive to these peasant communities. Rather, the idea of seeds as a "common heritage," as the FAO's Commission of Plant Genetic Resources defined them in the 1980s, was predominant in the international treaties regulating the universal practices of seed diffusion and dispersal—which are essential for genetic evolution. Indeed, these treaties used to reinforce the historical relations of reciprocity involved in seed exchanges (Brush 2005: 2-8). It was not until the $1990 \mathrm{~s}$, when neoliberal reforms aiming to privatize genetic resources were enforced, when seeds and genetic resources lost their "taken for granted" common heritage status (Brush 2005, De Schutter 2009, Golay 2016, Kloppenburg 2004). Since UPOV eliminated peasants' exception rights in 1991, the universal idea of seeds as common heritage is no longer supported on legal grounds (see Chapter 4) (Golay 2016). It is in this neoliberal context where the discussion of native seeds as part of these communities' commons is particularly relevant. DESMI's workshops attempted to 
address this conceptual vacuum.

The activities DESMI carried out in these workshops progressively increased in cognitive complexity. For instance, peasants began by identifying the crops they produce and distinguishing between those intended for self-consumption and those for the market. Peasants also explained where their seeds come from: Do they use inherited seeds? Do they exchange seeds with their neighbors or with members of other communities? Do they buy seeds? If they do, what kind of seeds, and what are the sources? (see Figure 13). As I explained in Chapter 4, almost all peasants in these communities are seed selfsufficient, which means that their native seed systems are functionally outside of commercial circuits. It is also important to reiterate that these communities are primarily focused on subsistence agriculture and that surpluses are only sporadically sold. Even those communities producing coffee for the market (Cancuc and Tumbalá) do so on a small scale. This is particularly the case since 2012 when the roya (a coffee disease) began to reduce coffee production in Chiapas (González 2016, SENASICA 2013).
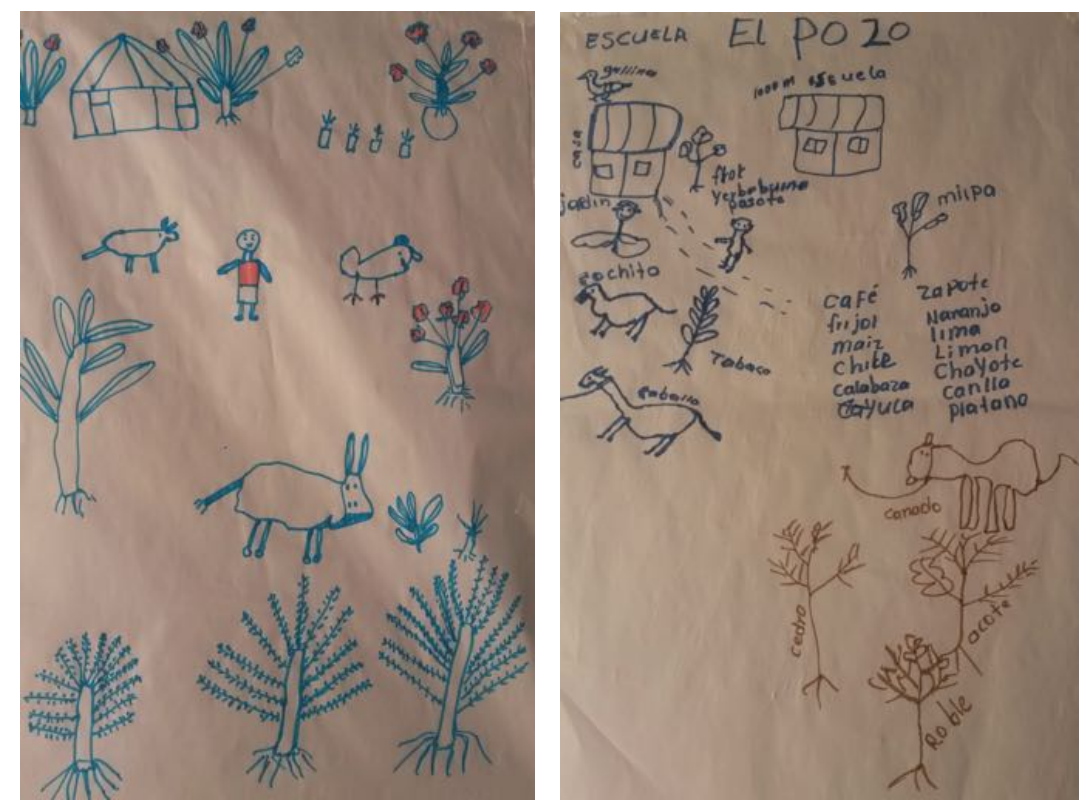


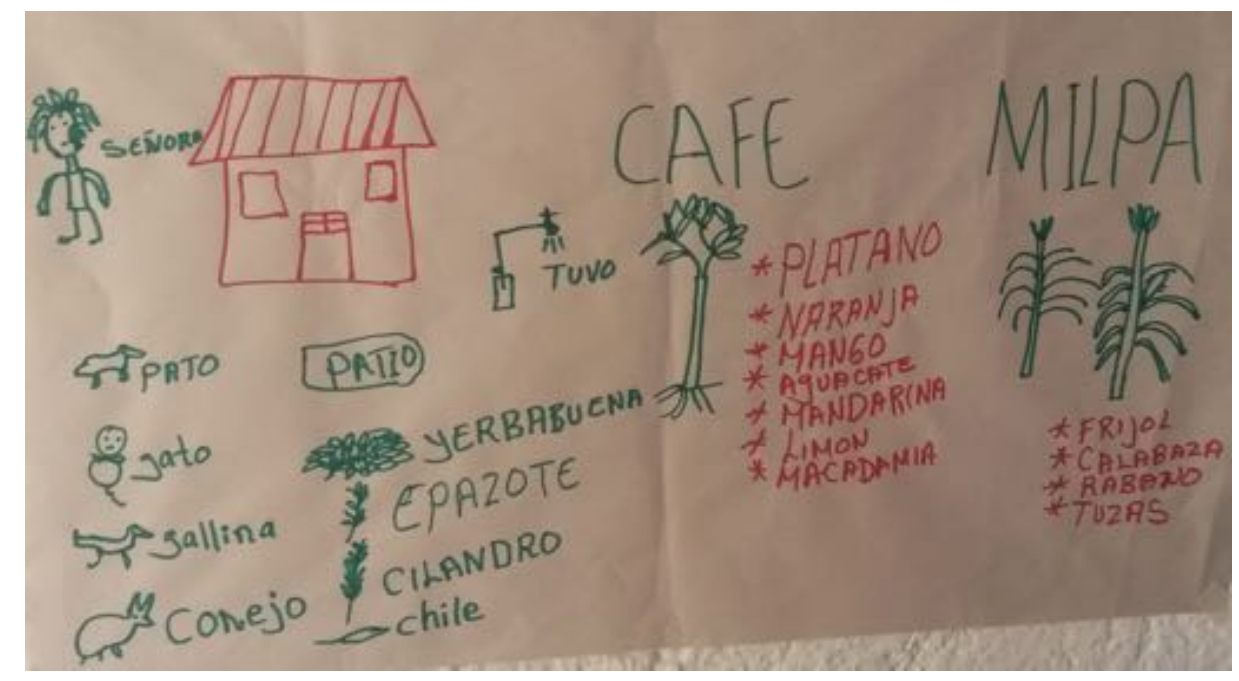

Figure 13. What do we produce? Where do our seeds come from? Using "talking maps," one of the peasant-to-peasant methods, peasants from Cancuc identified their communities as the source of their seeds. Above right and below: maps made by men. Above left: map made by women. It is worth emphasizing that all women in this group are illiterate, which is why there is nothing written on their map. Photographs by author.

In a second phase of these workshops, peasants described how they reproduce their seeds through the agricultural cycle: from the original acquisition of seeds (inherited, exchanged, bought, or self-produced), passing through the sowing, harvesting, selection, and preservation of new seeds, to the beginning of a new cycle. Indigenous peasants also talked about some of the spiritual rituals they perform during the agricultural cycle; for instance, before sowing or after harvesting their crops. The objective of this exercise was to collectively define what a native seed system means and to identify all of the processes involved in its reproduction. Although the reproduction of seed systems is common and well internalized knowledge for any peasant who reproduces his or her own seeds - they learn to do it since they are children - it can be more difficult for them to put it into words. This exercise was important for two reasons. First, it allowed peasants to view their communities' seed systems as the sum of 
individual agricultural cycles. Second, it served to identify the differences between native (informal) seed systems and industrial (formal) seed systems, a distinction that is important when seed laws are discussed.

In fact, this exercise was the preamble to the discussion of the 2007 Federal Law on Production, Certification, and Commercialization of Seeds. DESMI staff members introduced the law and explained its potential implications for communities' native seed systems. They also clarified the differences between formal and informal seed systems. This presentation was followed by a group discussion in which peasants expressed their ideas about how their communities might be affected by such regulations. It is important to recognize that, considering that DESMI is the fundamental (and frequently the only) source of this information, what peasants understand about this law is directly determined by the way DESMI interprets and explains it. These presentations are not politically impartial at all. Specifically, DESMI emphasizes the potential privatizing impacts that this law might have on native seeds, and identifies concrete actors who might benefit from such privatization — essentially Monsanto and other international corporations that control the seed and agrochemical market. However, it is necessary to point out that DESMI's interpretation of this federal law is not totally accurate, because this law regulates formal seed systems, and does not explicitly address informal seed systems (Government of Mexico 2007). 


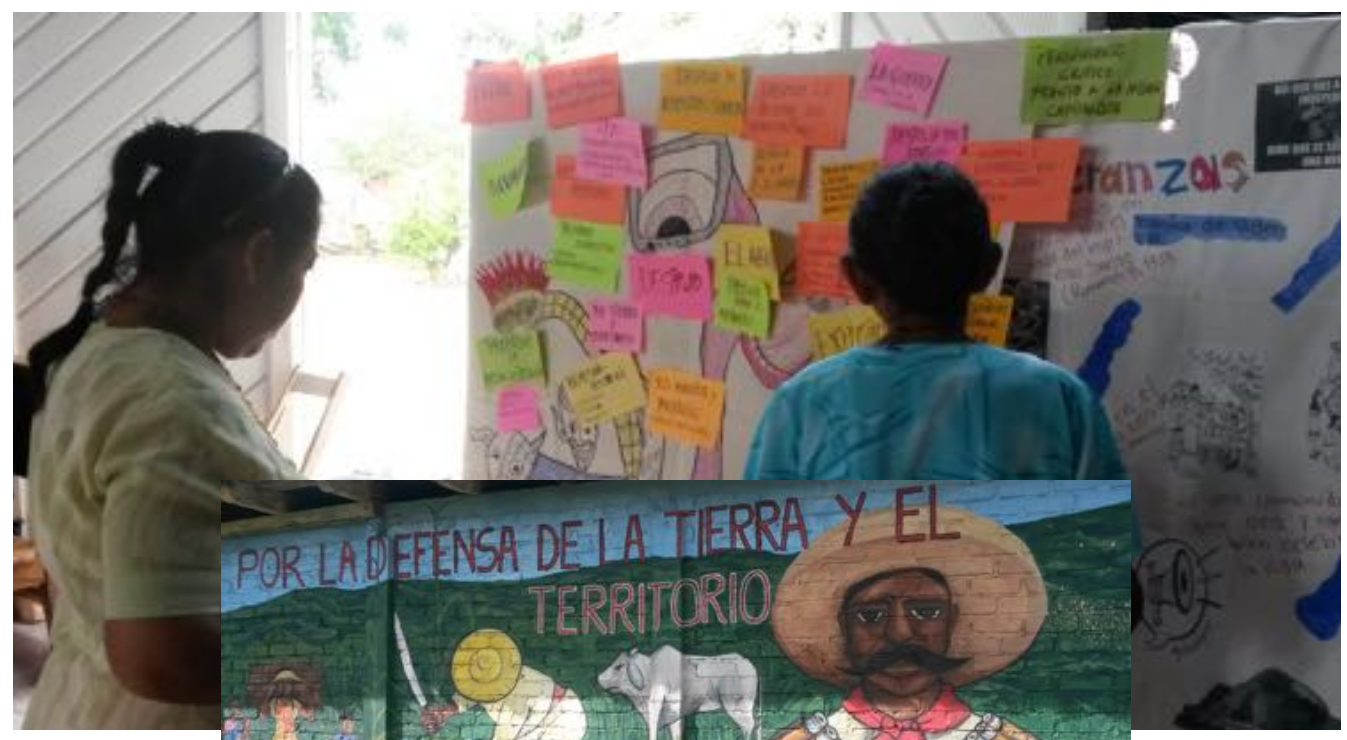

Figure 14. Introductory workshop with mestiza women: the capitalist hydra. Photograph by author.

This misinterpretation of the law is not exclusive to DESMI, however. DESMI's staff itself is influenced by the sources informing its members. For instance, at the moment of my fieldwork, the main source of information about the Mexican federal law on seeds was not the law itself, but the book Las Semillas del Hambre: Ilegalizar La Memoria Campesina (Seeds of Hunger: Illegalize the Peasant Memory, CECCAM 2009), a joint edition by well-known scholarly institutions, social movements, and international organizations such as CECCAM (Center for Change in the Mexican Countryside) in Chiapas, La Via Campesina, the Swedish Naturskyddsföreningen, and the American CS Fund and Warsh-Mott Legacy. This small book is a collection of seven case studies discussing seed laws in different countries such as India, Germany, Spain, and, of course, Mexico (among the authors are GRAIN, Vandana Shiva, and Ana de Ita). The objective is to contextualize Mexican seed regulations as part of an international process of seed privatization. A central argument of the book is that if this kind of laws continue to be 
enforced in the global South, countries that are now characterized by the prevalence of informal seed systems might end up trapped in a situation similar to that of the European Union or the U.S., where peasants have been dispossessed of their rights to freely reproduce their own seeds while attached to privatized industrial seed systems (CECCAM 2009). An excerpt from the preface—written by Alberto Gómez, from La Via Campesina North America—offers an example of the book's central argument:

The 2007 Mexican law on seeds was perceived by both peasants and experts as an example of madness, an aberration. It could not be possible that the government would attempt to prohibit and illegalize the peasant practices of selecting, saving, exchanging, selling, and re-sowing the seeds that had been used in the previous agricultural cycle. These are the very same practices that had given life to agriculture near 10,000 years ago and allowed the development of civilizations...The experience of European peasants indicates that the Mexican law is there for seed companies and corporations to use it when they consider necessary. In Europe, the large majority of peasants have lost their seeds and they now need to buy commercial seeds every year. The Mexican law on seeds prohibits peasants from selling and exchanging non-certified seeds - that is, noncommercial seeds. The law also forces peasants to pay companies a percentage [sic] if they decide to re-sow their own seeds... The objective of this book is to make clear the threats that loom over peasant seeds and put at risk the very essence of peasants (2009). 


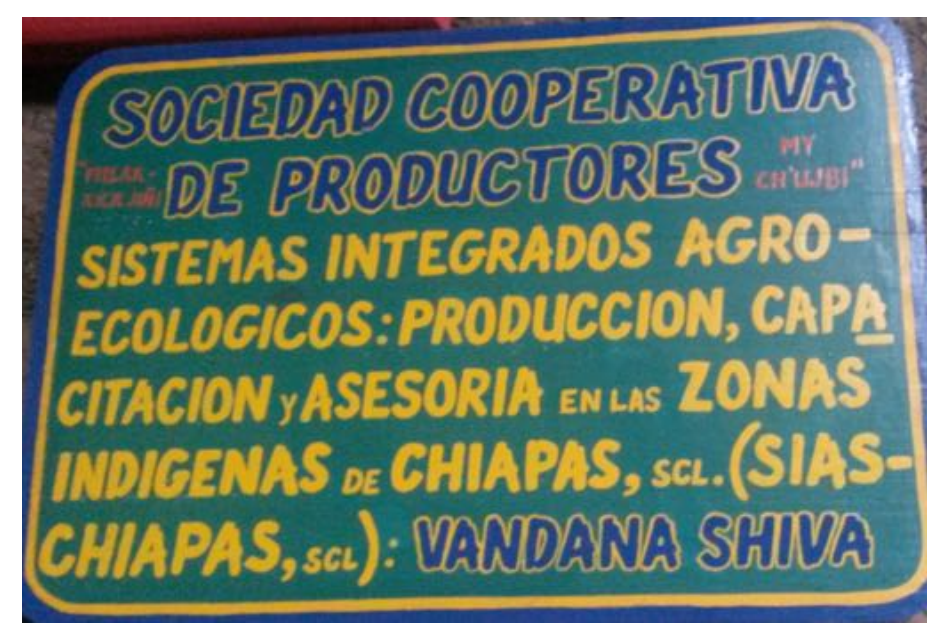

Figure 15. The Vandana Shiva cooperative society of agroecological producers in the Cideci. Photograph by author.

After a few years of working on this subject, it seems to me that resisting, on the grounds of an anti-privatization political stance - rather than on the laws' actual content—any legal initiative that could potentially lead to the regulation of native seed systems is a precautionary measure taken by many organizations (including DESMI) and social movements involved in "the defense of native seeds." And they might be right. As the long history of seed commodification suggests — and as the most recent case of Colombia illustrates (see Wattnem 2016) - these regulatory regimes establish the legal ground on which other laws targeting informal seed systems can be later implemented (Kloppenburg 2004).

At the end of this workshop session, and in line with the book Seeds of Hunger, peasants came away with a couple of clear ideas: first, that the Federal Law on Seeds is an attempt by the government to open the way for the privatization of native seeds; and second, that this law responds to Monsanto's interests and favors its long-term efforts to steal peasant communities' native seeds and replace them with GMOs. Indeed, some 
activists from other organizations in San Cristóbal and Mexico City I spoke with call this law “Monsanto's law on seeds."

It is also worth noting that even if peasants did not have information about the existence of this federal law on seeds before the workshops, almost everyone in the region knew of Monsanto and had an opinion about this corporation as an entity that wants to grab their seeds and contaminate them with GMOs. Peasants also know Monsanto because most of them use its agrochemicals, particularly glyphosate-based herbicide, in their own parcels (see Chapter 4). This widespread perception, which is also present among many other peasant communities and small industrial farmers across the country (see Camou Guerrero 2015), is not surprising after years of social movements, civil society initiatives, and NGOs targeting this corporation, including the EZLN, Sin Maíz No Hay País, MA OGM, GRAIN, and DESMI, among others. As I have argued, Monsanto has been identified by activists around the world as the ultimate representation of the biotechnology industry, not only because of its international reach but also because of its monopolistic practices targeting governments, farmers, social movements, and civil society organizations alike (Camou Guerrero 2015, Siegel and Betz 2016). On May 23 ${ }^{\text {rd }}$, 2017 alone, for example, thousands of people marched in 400 cities of 40 countries against this corporation (GMWATCH 2017, MAM 2018, RT News 2017).

The last stage in DESMI's introductory workshops consisted of peasants identifying concrete measures that they could take in order to protect their seed from potential privatization. For this exercise, peasants split into small discussion groups, wrote some notes (see Figure 16), and then shared their ideas in front of the whole group. 
Not surprisingly, all of the groups arrived at similar conclusions: first, that it is possible to prevent the introduction of GMOs into their communities if peasants avoid buying and using seeds from an unknown source-a practice that already exists in these communities; second, that it is important to explain to other members of their communities what the federal law on seeds is about and how it affects their native seeds; and third, that peasant communities are able to take care of their own seeds.

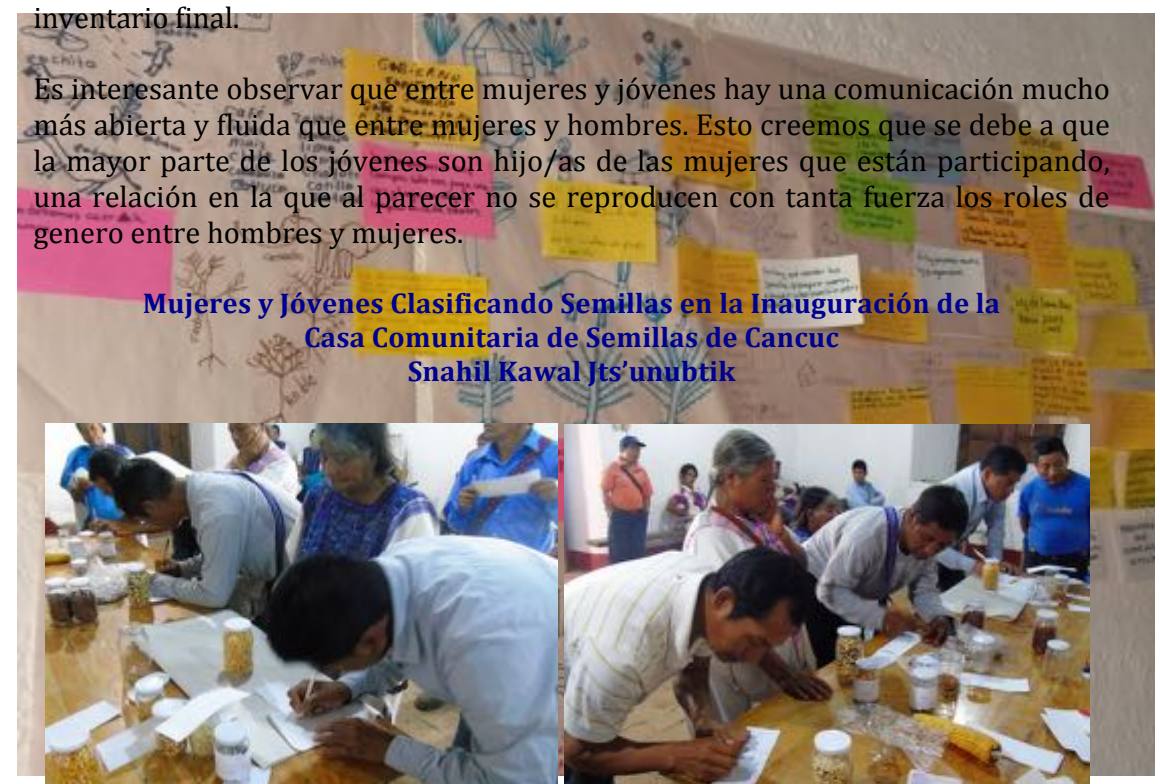

Figure 16. Peasants from Cancuc identify some strategies they can adopt in order to protect their seeds. Photograph by author.

The following quotes are some of the ideas peasants shared at the end of the workshops. It is worth noting that all of the participants emphasized the notion that native seeds are their own and that communities have the responsibility to protect them. Ruben, a mestizo peasant from Teopisca (group 4, see Table 12), said, "we need to protect our seeds from Monsanto and tell others to do the same because, if we do not defend our seeds, this corporation will appropriate them." ${ }^{3}$ The small group of mestiza women from 
Teopisca (group 5, see Table 12) also referred to Monsanto but framed the topic in different terms and introduced the issue of GMOs: "We do not like Monsanto and we want to use our own seeds. Why do we need to use other seeds if we have our own? Nobody will buy our tortillas if we give them [consumers] bad maize [transgenic corn]."4 Jtsiak, a Tseltal peasant from Cancuc, advanced the discussion, emphasizing the distrust these communities feel towards the federal government: "These are our seeds. We cannot trust the government any more; only bad things come from the government. We are tired of the government, always cheating us!...We have to protect what is ours. Seeds are ours. We do not understand very well what a transgenic [seed] is, because we did not have the opportunity to go to school, but we know that transgenic seeds are not good for us; transgenic seeds kill our seeds." Antonia, a Ch’ol woman from Tumbalá, made the connection between native seed systems and food security, which was the ultimate goal of these workshops:

Seeds are our food. Without them we have nothing to eat. It is clear for us now that we have to protect our seeds from those who want to steal them. Transgenic seeds are not good for us... We do not know how to recognize a transgenic seed from a normal seed; thus, it is better if we only use our own seeds because we know where they come from. We can keep our seeds healthy if we take care of them. ${ }^{6}$

As these quotes reflect, these workshops effectively framed native seed systems as a protected commons and contextualized them in relation to external phenomena such as the spread of GMOs, the implementation of federal laws on 
seeds, or the increasing privatization of seed systems at a global scale. This understanding of native seeds as a protected commons reinforces the politicization of seeds and the dichotomy between industrial and native seed systems.

\section{Knowing and Preserving the Commons:}

\section{Communities' Seed Inventories and Seed Banks}

Beyond opposing federal regulations on seeds and transnational corporations, DESMI's seed sovereignty project is really about expanding the knowledge that peasants have about their own seed systems. This is a prerequisite for communities to embrace their seed systems as a part of their commons. DESMI's central strategy to achieve this goal was to develop community native seed inventories and to create community seed houses (seed banks).

These exercises were an enriching experience for both DESMI and community members, and they highlighted the role that women play in the preservation and reproduction of seed systems. Women proved to have a much more extensive knowledge about seeds that men had. While men were able to identify crops, it was women who identified and named most of the plants, vegetables, medicinal herbs, flowers, trees, and animals that can be found in these communities. Women were also able to say which of those plants are edible, and how they can be reproduced. 


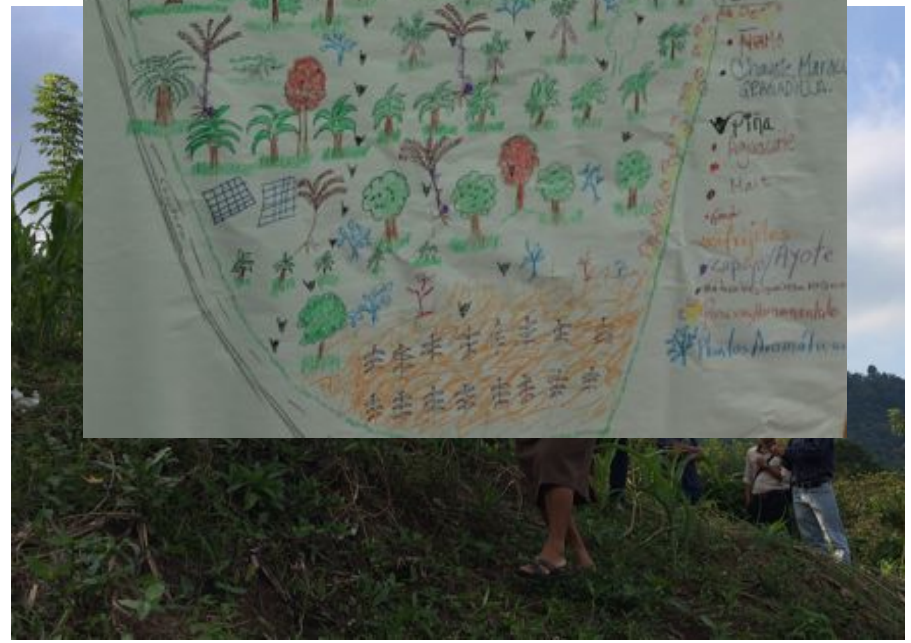

Figure 17. Mothers and children in search of native seeds, Tumbalá. Photograph by author.

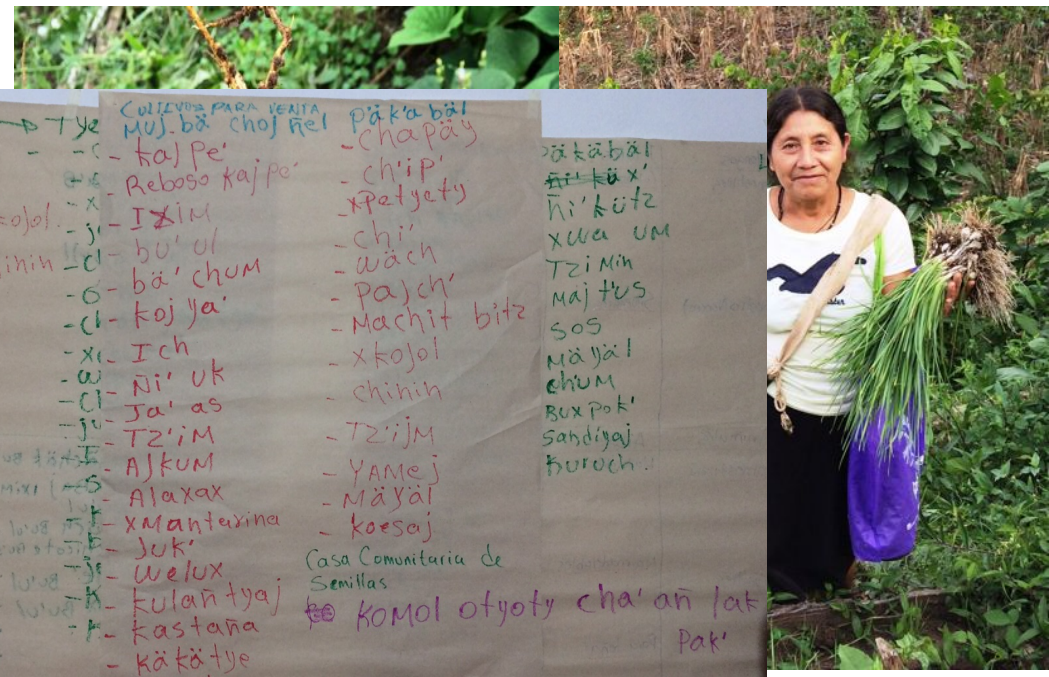

Figure 18. Woman with native peanuts, Tumbalá. Photograph by author.

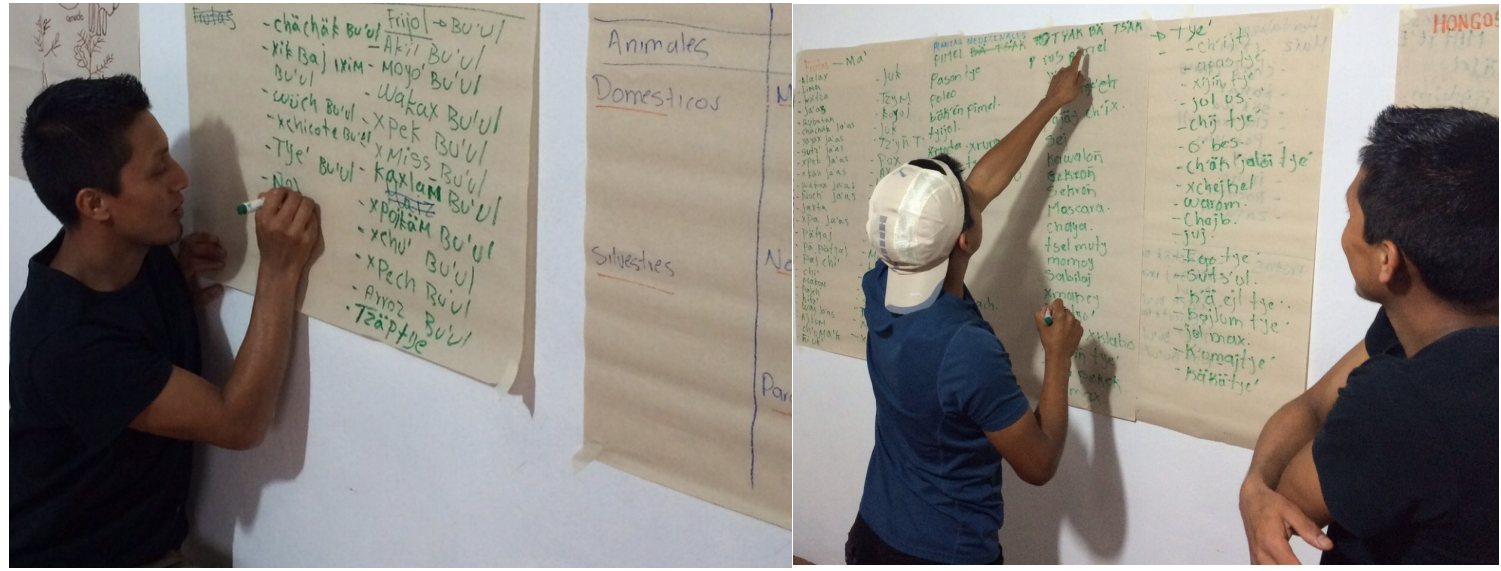

Figure 19. Youths writing down seed names for the seed inventory, Tumbalá. Photograph by author. 

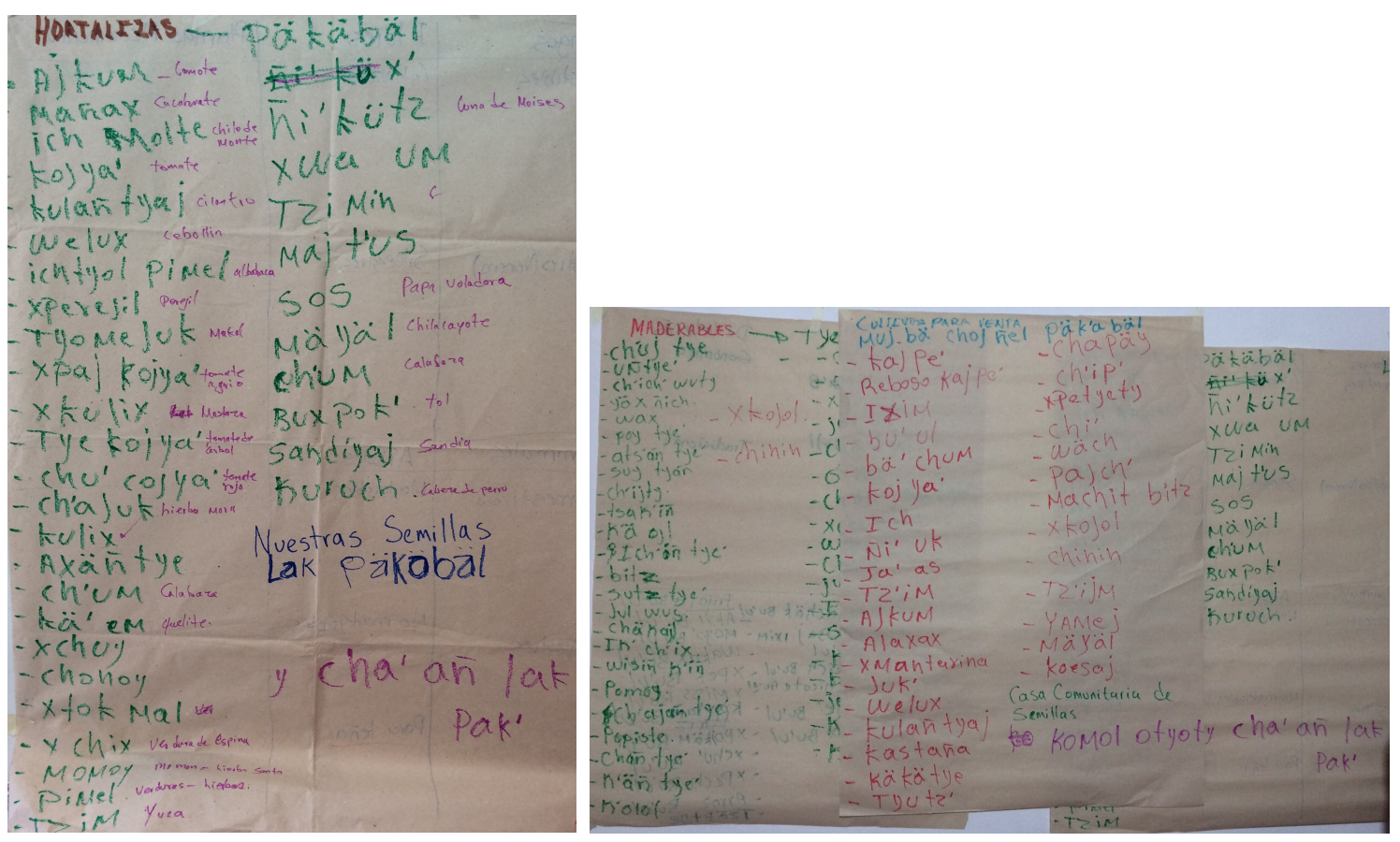

\begin{tabular}{|l|l|}
\hline \multicolumn{1}{|c|}{ Ixim-Maíz } & \multicolumn{1}{c|}{ Bu'ul-Frijol } \\
\hline Se identificaron 9 variedades: & Se identificaron 17 variedades: \\
Chak cha'b (Maíz Negro) & Akil Bu'ul \\
K'anal (Maíz Amarillo) & Moyo' Bu'ul (Frijol de Barra) \\
Sak wa (Maíz Blanco) & Wakax Bu'ul (Frijol Cubano) \\
Cha'lam sujl (Maíz Rojo) & Xpek Bu'ul (Frijol de Tierra) \\
Pek Izim (Maíz Chaparro) & Xmiss Bu'ul (Frijol Pinto) \\
Suy (Maíz Balancán) & Kaxlan Bu'ul \\
Irviro (Maíz Balancán) & Xpojkam Bu'ul (Frijol Botil) \\
Rocame & Xchu' Bu'ul \\
Zapalote & Xpech Bu'ul (Frijol de Pato) \\
& Arroz Bu'ul (Frijol Arroz) \\
& Tzaptije (Frijol de Barra) \\
& Chachak Bu'ul (Frijol Rojo) \\
& Xik Baj Ixim Bu'ul \\
& Wijch Bu'ul \\
& Xchicote Bu'ul (Frijol de Chicote) \\
& Tye' Bu'ul (Frijol de Bara) \\
& Nox Bu'ul (Frijol Verde) \\
\hline
\end{tabular}

Figure 20. Lak Pakobal ("Our Seeds," in Ch'ol): excerpt of the final inventory (maize varieties left, bean varieties right), Tumbalá. Photographs by author.

After four months of work, the final outcome was a multilingual native seed inventory (in Tseltal, Ch'ol, and Spanish) consisting of five sub-inventories, one for each group of communities. DESMI printed and distributed copies to all 25 communities that 
participate in the project. Indigenous peasants were very pleased to discover that the inventories from Cancuc and Tumbalá (groups 1 and 2, see Table 12) had, on average, 280 seed varieties, taking into account both domesticated and wild varieties of crops, vegetables, fruits, herbs, flowers, and trees. The inventories from mestizo communities were, as expected, much lower: an average of 120 varieties for groups 3 and 4; and only 42 varieties for the group of mestizo families with women as heads of household.

The making of native seed inventories served a similar function as the exercise in which communities identified and explained the different processes that are involved in the reproduction of their native seed systems. This knowledge is inherent to these peasant communities, but these exercises helped them to collectively systematize it. These workshops also opened a space in which peasants could talk about everyday practices that are so common in these communities that people do not consider them as having particular relevance. However, as I have tried to emphasize throughout this chapter, these collective practices are themselves an essential component of these communities' commons.

These exercises also helped to emphasize that even if native seeds are conceptualized of as a "common heritage" or "universal commons," seed diversity and seed systems are directly related to the peasant communities that inhabit these territories. In other words, these workshops were useful for highlighting the key role that peasants play in the reproduction, preservation, and evolution of such diversity.

Regarding the community seed houses, at the end of my fieldwork only the communities of Cancuc had created a preliminary seed bank (see Figure 18), and DESMI 
was considering advancing the project toward the creation of live seed banks - the model of seed banks developed in Zapatista territory (Mother Seeds in Resistance, see Chapter 4; and Brandt 2014 and Brown 2013). In contrast to conventional community seed banks, in which peasants preserve their seeds in containers (see Figure 18), live seed banks are collective experimental parcels where peasants reproduce seeds and experiment with different varieties. Live seed banks also accomplish a more structural goal directly related to the preservation and evolution of biodiversity: to promote the reproduction of varieties that are not frequently cultivated by peasants.

Behind DESMI's modification of the original project was the consideration that the making of the seed inventories had been quite successful and the exercise had accomplished the project's overarching goal of helping these communities to recognize the vast diversity of their seed systems.

Although peasants in the Guardians of Mother Earth and Seeds Project were able to identify more than 200 seed varieties, this does not imply that they cultivate and consume all of them. A good example is maize. Despite the high maize diversity in the region (participants identified 20 varieties in Cancuc and 17 in Tumbalá), peasants' diets mostly rely on two varieties: white and yellow maize. According to Perales, although 21 races of maize are reported in the germplasm banks for Chiapas, the average number of maize varieties cultivated per farmer in the region is between 1.1 and 2.7 (2016: 273). This implies that the large majority of varieties have been relegated to sporadic reproduction, with attendant implications for the simplification of communities' diets and biodiversity. 

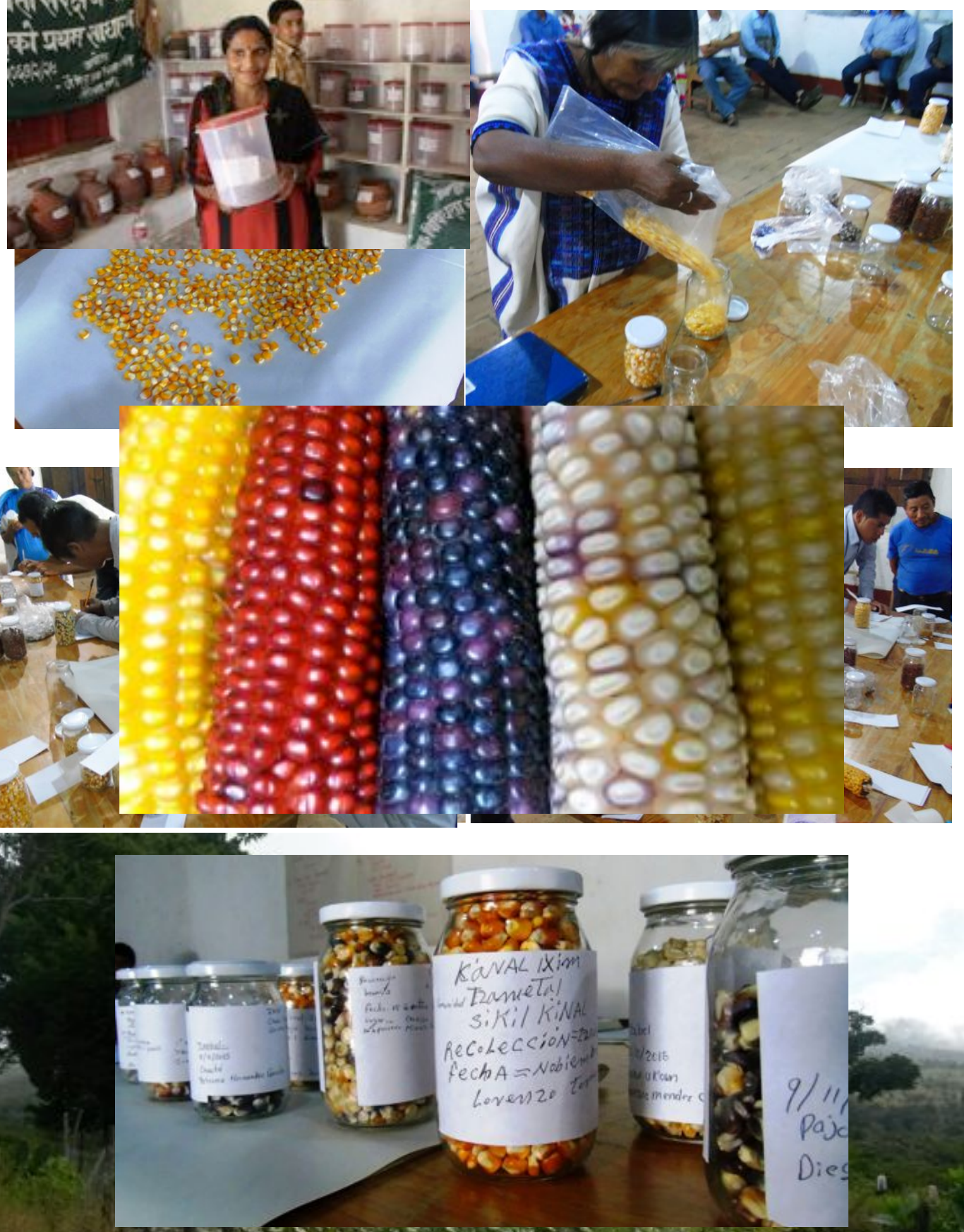

Figure 21. Snahil Kawal Jts'unubtik (“Our Community Seed House," in Tseltal): the making of a seed bank, Cancuc. Photographs by author. 
The Zapatista project of live seed banks is an attempt to reverse the impacts of this near-monoculture practice, limit crop genetic erosion, and enhance agro-biodiversity. With these objectives in mind, the Zapatista committees of agroecology work on two fronts: to promote the diversification of maize production among Zapatista peasants, and to develop collective experimental parcels. According to Jtin, a Zapatista Tseltal man from Tenejapa, "before, we cultivated white maize and, sometimes, yellow maize; after all those workshops with the organization [the EZLN], we started cultivating other varieties. Now I am producing five different colors of maize: white and yellow, but also pinto, black, and red. My children cultivate some other varieties."7

Complementing what peasants cultivate, the agroecology committees are responsible for coordinating the collective parcels, in which a wider variety of seeds are reproduced. One of the experimental parcels I visited in a community from the Oventic Caracol had 12 varieties of maize and eight varieties of beans. Besides promoting the diversification of peasants' diets, these collective parcels have the specific purpose of conserving and reproducing agro-biodiversity, a key requirement for climate change adaptation (Dyer et al. 2014, Mercer et al. 2010, 2012, Perales 2016). The development of these collective experimental parcels reinforces the long-term work that DESMI began in the late 1980s when it started to promote the diversification of maize cultivation among indigenous communities in the region (DESMI 2001). 


\section{Making the Connection:}

\section{Organic Production, Food Security, and Seed Sovereignty}

Another key axis of DESMI's seed sovereignty project is organic agriculture. As I discussed in the last chapter, the transition from conventional to organic methods of production aims to achieve at least three structural goals: to preserve these communities' ecosystems, to enhance subsistence agriculture, and to weaken peasants' dependence on external food markets and industrial inputs, primarily agrochemicals. DESMI has promoted this transition for decades, and I have already described the positive role that the international solidarity market for fair trade and organic coffee has played in the adoption and maintenance of organic agricultural practices in this region.

However, there is also a more contemporary phenomenon that has boosted this long-term transition in a decisive way. Paradoxically, this time the origin was not an alternative market based on premises of social and environmental justice, but the biotechnology industry and the worldwide spread of GMOs — which has entailed a sharp increase in the use of agrochemicals, mainly glyphosate (Benbrook 2016). As I discussed earlier, the issue of GMOs, both in Mexico and globally, has been controversial to say the least. Reinforcing this opposition from civil society is the rapid accumulation in the last few years of scientific evidence on the pervasive impacts of glyphosate on the health of both humans and ecosystems (IARC 2017, Kelland 2017, Silva et al. 2017, The Guardian 2016; see Chapter 4).

DESMI and the EZLN have been able to capitalize on this political context and articulate a conceptual connection between the political defense of native seeds and the 
adoption of organic methods of production. This connection is grounded in two complementary propositions. The first is a defensive proposition that aims to fence off the commons - in this case subsistence agriculture and native seeds - and to protect them from GMOs, agrochemicals, transnational corporations, and "privatizing" laws. The second is a proactive proposition that aims to reverse the destructive aspects of the market and enhance the resilience of native seed systems through the adoption of organic agriculture, the reproduction of biodiversity, and the implementation of crop genetic evolutionary practices (e.g., live seed banks) to adapt to climate change.

As I have discussed in the preceding chapter, the EZLN has made considerable advances in both directions. Although incomplete and uneven, these processes constitute the basis of the alternative model of agriculture in which the Zapatista decommodification project is rooted. Among the EZLN's initiatives, one of the weakest or least advanced processes is the full conversion of the milpa into organic agriculture. Paradoxically, Zapatista communities have successfully adopted organic methods of production in almost every other agricultural area: coffee, honey, vegetable and herb gardens, mushroom labs, experimental maize parcels, and even collective milpas. However, individual milpas - which happen to be the fundamental source of food for these communities - remain the one space in which agrochemicals are still widely used.

There is one key factor influencing this development: the amount of labor and expertise that organic production requires, which is considerably higher in poor and deeply degraded soils like those of the milpas in the study region. A different situation is found on those lands that were expropriated from the fincas, which are better suited for 
agriculture and are also less degraded (Barmeyer 2009). According to the researcher Hugo Perales, it would take an average of three to five years of intensive care- that is, actively implementing techniques for soil recovery such as the construction of live and dead terraces, the application of organic fertilizer, and the diversification of crops-in order to start reversing the damage that has been inflicted on the soil. For instance, in the study region, Perales calculates that it would be necessary to start with the application of about 10 tons of organic fertilizer per hectare during the first three to five yearspeasants cultivate an average of two hectares of milpa. Only after that initial period, the amount of fertilizer applied could be progressively reduced to a minimum of four to five tons per hectare, a transition that would take another eight to 10 years to complete. Moreover, Perales emphasizes, it is necessary to take into account that most of these peasant communities entirely rely on their own manual labor and do not have access to machinery (e.g., for making organic fertilizers or construct erosion-control terraces). ${ }^{8}$

Going back to the slash-burn-and-fallow methods of the traditional milpa system seems out of question in a context of land scarcity, overpopulation, and chronic deforestation. Indeed, DESMI has strongly encouraged the abandonment of slash-andburn methods altogether, and the EZLN has implemented anti-deforestation regulations that sanction peasants who burn down their forests - a measure that has been complemented with reforestation programs. ${ }^{9}$

According to Mariano, a DESMI staff member, one solution to the labor and land scarcity dilemmas might be the collectivization of the milpas — an idea, he says, that has been extensively discussed by the Zapatista leadership. On one hand, it would allow for 
the rotation of parcels, which is beneficial for the soil; on the other, it would reduce the amount of individual work required to implement agroecological techniques, all of them labor intensive. In Mariano’s words:

the implementation of the agroecological model requires the collectivization of labor. Individual families cannot make the transition alone. You cannot ask peasants to invest all of their time cultivating an organic and diversified milpa-for instance, each crop has its particular cycle, you do not sow and harvest all crops at the same time; therefore, more crops means that more time and work have to be invested in the milpa. People need to have enough time for other activities besides producing their own food. Peasants need cash, but they also need time for their political, religious, and pleasure activities. If you are part of the movement [the EZLN] you need a lot of time to accomplish your responsibilities, from community meetings to cargos [unpaid leadership positions]. You cannot live in your milpa. The collectives [coffee, honey, vegetable gardens, mushrooms] are successful because people work together and concentrate their resources. I believe that is the key. ${ }^{10}$

However, as Barmeyer (2009) and Klein (2015) have noted, challenging peasant communities' traditional structures of land tenure — materialized in individual plots of land which are "owned" by male head of households, one of the main achievements of the Mexican Revolution of 1910 - is politically risky, and it is probably one of the few issues in which the EZLN has not strongly interfered. The exceptions, Barmeyer notes, are those communities that were created on land occupied after 1994 - the hard core of 
the EZLN—which are more homogeneous in political, economic, and demographic terms than the rest of the communities that comprise the EZLN. The large majority of Zapatista communities are former comunidades agrarias or ejidos, and their participation in the movement has not interfered with their original form of land tenure. In addition, the communities that were recently formed on finca land have better agricultural soils, which has allowed them to advance agroecological practices to a higher level than the rest of the communities.

Another issue worth noting is that productive collectives are successful and sustainable because they are based on the voluntary participation of peasants - a key premise of DESMI's model of solidarity economy (DESMI 2001). The movement does not force anyone to collaborate in those collectives or to adopt agroecological practices. Encouraging the participation of peasants is the responsibility of communities themselves, and the EZLN committees of health, education, and agroecology contribute to accomplishing that objective. Taking into account these elements, it seems difficult, at least in the near future, to envision that peasants will collectivize their milpas. In this context, it is worth asking whether the Zapatista movement would be able to overcome the labor and land scarcity dilemmas that have thus far prevented advancing the agroecological model at the milpa level.

This discussion serves to contextualize the organic agriculture and food security issues raised by the Guardians of Mother Earth and Seeds project. As I mentioned earlier in the chapter, DESMI has focused most of its efforts on the creation of projects aiming to enhance communities' food security (see Table 12). Beyond these initiatives, DESMI 
has organized several workshops on agroecological techniques. These are basic trainings in which a DESMI staff member explains some methods and makes an empirical demonstration — for instance, preparing a couple of organic fertilizers or measuring the contours of a milpa to design live and dead terraces. In those communities where collective vegetable gardens or coffee nurseries have been sustained for at least two years, DESMI also introduces other experimental exercises, such as pest control or seed breeding techniques. In other words, these collectives work as small laboratories in which peasants can collectively experiment with different agroecological techniques.

At the time of my field research, resolving the milpa dilemma—that is, making the organic transition in the milpa - was still out of reach in these communities. However, it seemed to me that peasants had understood that producing organically was a fairly straightforward way to protect their native seeds. It was also clear to them that agrochemicals come from the very same source that, in their view, now is threatening their native seed systems with privatization: the biotechnology industry, and specifically Monsanto. These understandings are a key success of DESMI's seed sovereignty project. As can be deduced from the above descriptions, it is essentially a question of degree what differentiates DESMI's projects in Zapatista communities from those implemented in non-Zapatista communities. The former have a fairly long history of experimenting with agroecological techniques and the collectivization of labor, resources, and production, from which the non-Zapatista communities have greatly benefited. Many of the projects developed in non-Zapatista communities have been successfully implemented because they were first tried, developed, and refined in Zapatista 
communities. In other words, non-Zapatista communities are beneficiaries of an accumulated knowledge that has its origins in Zapatista communities. This transmission of knowledge is essential for explaining the success of those projects in communities DESMI began to collaborate with only a few years ago.

\section{Agroecology and War: Limits and Opportunities}

I want to conclude this chapter with a brief reflection on the consequences that the armed conflict has had in some of the communities that participate in this project. I will refer to the two mestizo communities that are adherents to the pro-Zapatista The Other Campaign (groups 3 and 4, see Table 12) because they have experienced the war firsthand. Both communities are involved in land conflicts and have adopted some resistance policies. Despite having some elements in common, however, these two communities have experienced the low-intensity war in opposite ways.

The community from Teopisca (group 4) is composed of 62 families who in 1995 occupied about 280 hectares of land from the finca they formerly worked on. Although these families were unable to regularize their land tenure through the Agrarian Accords of 1999 (see Table 11, and Chapter 3), they were not forced to leave their newly acquired land. Between 1995 and 2005 these families focused most of their energy on defending the land and preventing its former owners from taking it back. In 2006, when the EZLN launched The Other Campaign, 42 of the 62 families joined the Campaign and became adherents, which in this case meant that they "formally" became independent from the government, self-recognized their rights to this land, and assumed the responsibility of providing most of the basic services required for any community (e.g., potable water, 
roads, government institutions). "In 2006 we finally became a community and started working the land," said Felipe, a man in his 60s, during a group interview. "Before, we were always afraid of the patrones, who were threatening that they would come back for their lands. We were waiting for the government to recognize our right [to the land] and give us some services. That is how it worked before. You took the land and then the government came and recognized the community and granted you a title [of land ownership] and some services [water, electricity]... Now we are in resistance, we are organized." $" 11$

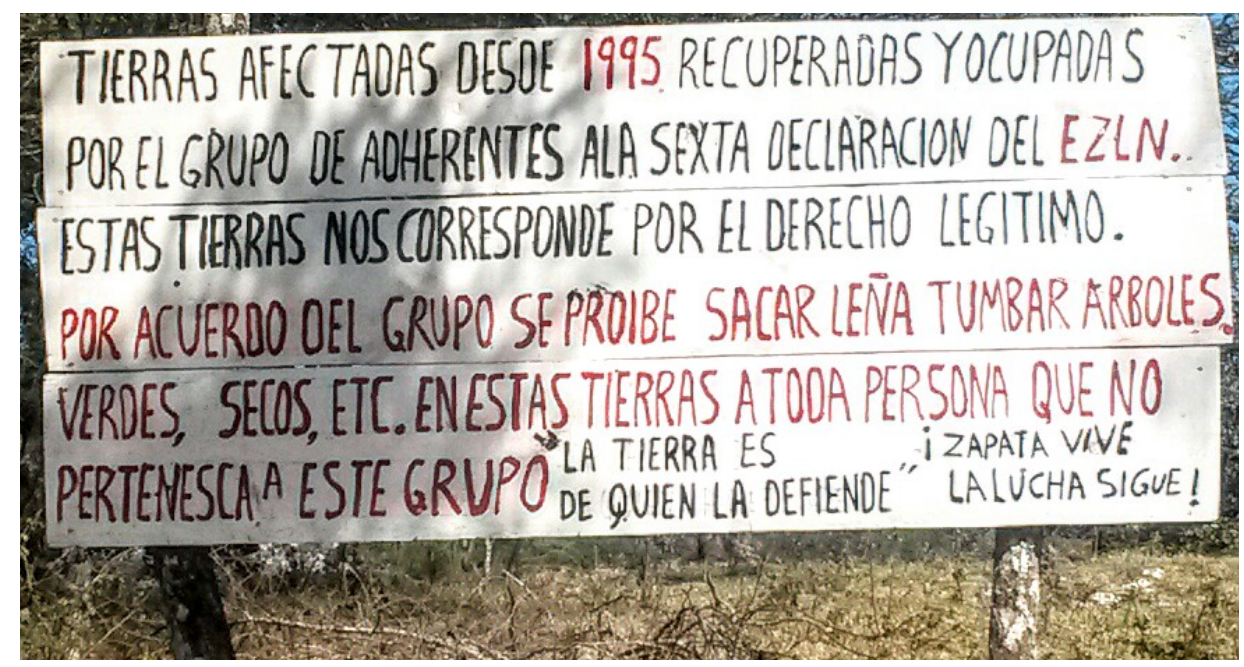

Figure 22. "The land belongs to those who defend it. Community Adherent to the Sixth [The Other Campaign]," Teopisca. Photograph by author.

Of the 25 communities that participate in the Guardians of Mother Earth and Seeds project, this particular community is where DESMI's projects are by far most consolidated. These families are not only better organized - a requirement for taking and defending land for over two decades — but they also have a solid material basis in which all these projects can be rooted. What happened here was something similar to those Zapatista communities that were formed on occupied land: these families started anew 
with the same quantity and quality of land and the same political and economic rights. As Barmeyer points out, new Zapatista communities were born from their political commitment to fight together for the land, and much of the political and socioeconomic stratification that exists in older communities is not yet present here. In other words, these communities are per se more egalitarian and it is easier for them to embrace collective projects that reinforce that common ground. Moreover, these communities are exempt from the interference of the government and political parties, whose programs and subsidies tend to reinforce socio-economic inequalities and create political divisions among their members (2009: 109-135). In addition to these elements, it is worth recognizing that this community from Teopisca - as with most communities created on finca land - has access to large amounts of high quality land and water, a privilege that very few peasant communities in the region have. These elements are key to explaining why this community has a higher number of collectives (six in total, with more than 20 different families participating in each), bigger and more productive collective organic vegetable and herb gardens, more diversified diets, and better milpas. 

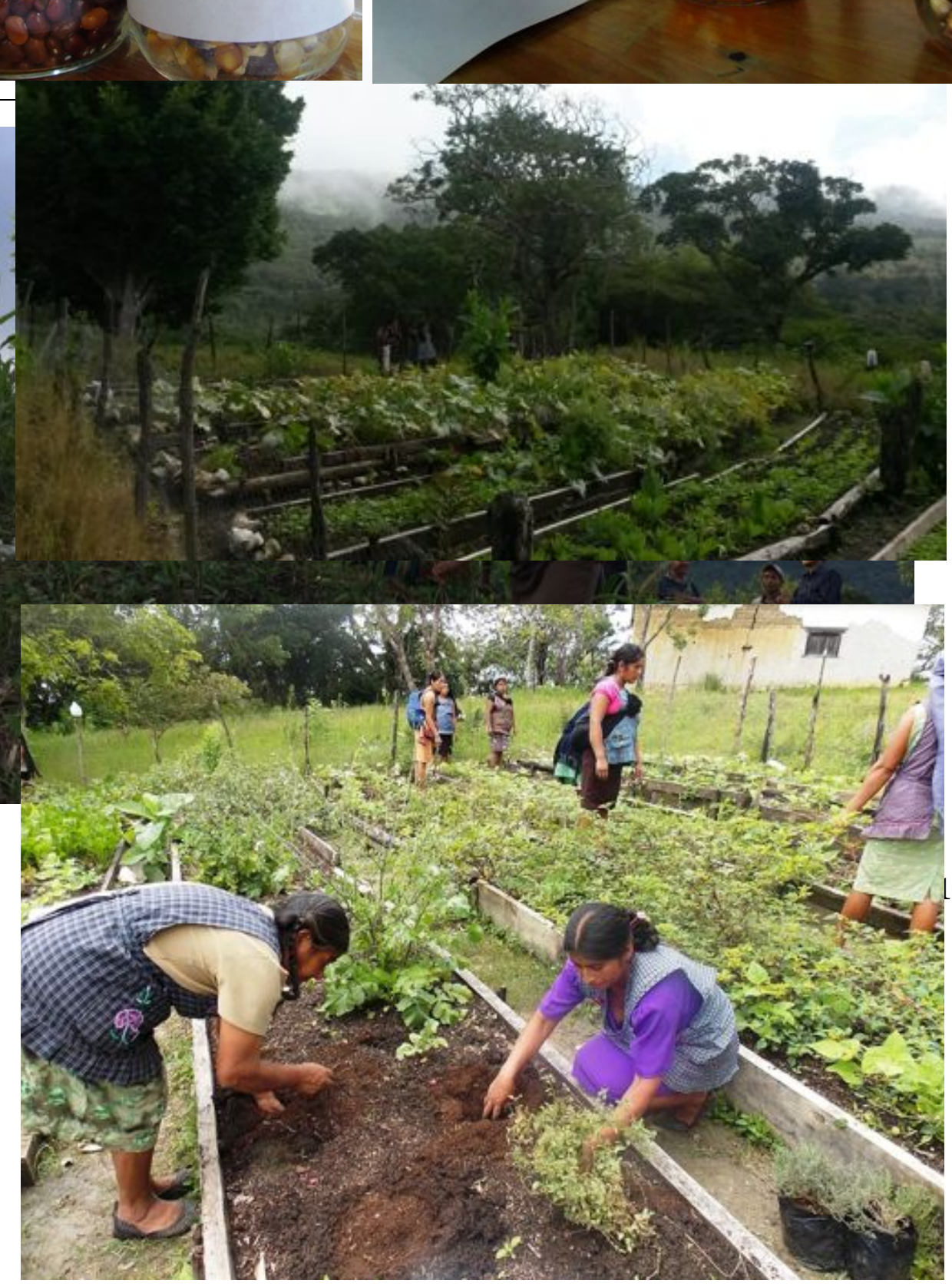

Figure 23. Collective organic vegetable garden, mestizo community, Teopisca. In addition to this garden, this community also has a very extensive organic herb garden. Photograph by author.

A very different experience is found in the community from Venustiano Carranza (group 3, see Table 12). At the time of my fieldwork, it was the most disadvantaged of the 25 communities that participate in this project. This community was created in the 
1960s on land that originally was part of a sugarcane plantation, which is the reason why this community has a collective for the production of molasses. In those years, 36 families who were working in the plantation occupied some land and demanded the government grant them the status of an ejido. In a political context in which agrarian reform was still part of the Mexican constitution, the government recognized the ejido and granted 500 hectares of land to those families, most of which was good quality land with access to water sources. "Before we took the lands, the sugarcane plantations controlled all the water in this region," says Adolfo, a man in his late 70s, during a group interview. "We did not have water on our parcels, not even to drink, but they [the plantation owners] had water for their swimming pools. They controlled all the land that had water. We were angry. We saw an opportunity when the former owners wanted to sell four ranches to someone from outside the municipality. In that moment we took the land and the government supported us." 12

This favorable situation started to change in 1994, when land occupations reached a climax after the Zapatista uprising. Some landless families started to occupy land from this ejido - more than expropriating land, those families really wanted to join the ejidobut the real problem came when paramilitary groups began to displace entire families and appropriate the ejido's best land. By 2012, after years of armed confrontations between ejido members and paramilitary groups, the original 36 families had been restricted to only 118 hectares — down from the 500 hectares that the government had granted themand they did not have access to any water at all.

That was the year when the community joined The Other Campaign. Although 
there are not many possibilities for recovering their lost lands, at least in the near future, this community has benefited from the support of the Oventic Junta de Buen Gobierno and some of the organizations that work with the EZLN, including DESMI. The Human Rights Center FRAYBA—created by Samuel Ruiz in 1989- has also been actively present in the region since 2012. Although these families continue to be threatened on a daily basis by paramilitary groups — for instance, frequently stealing their harvests or preventing peasants from accessing their milpas - the presence of the FRAYBA and other international organizations has considerably reduced the violence in the region.

These factors partially help to explain the food crisis in this community, whose households need to purchase most of their food, including maize and beans. At the time of my research, in addition to the effects of the war, a drought had impacted the region for almost four years - a phenomenon that contributed to the intensification of the conflict for water (see Chapter 4). Together, the drought and the war have eviscerated this community's capacity to produce its own food. In these conditions, DESMI's projects have been more focused on providing basic services and reinforcing the community collectives — strengthening solidarity bonds seems to be the priority for DESMI nowrather than truly attempting to make the transition to organic agriculture, which is quite difficult considering that this community does not even have water to cultivate a collective organic vegetable garden. 


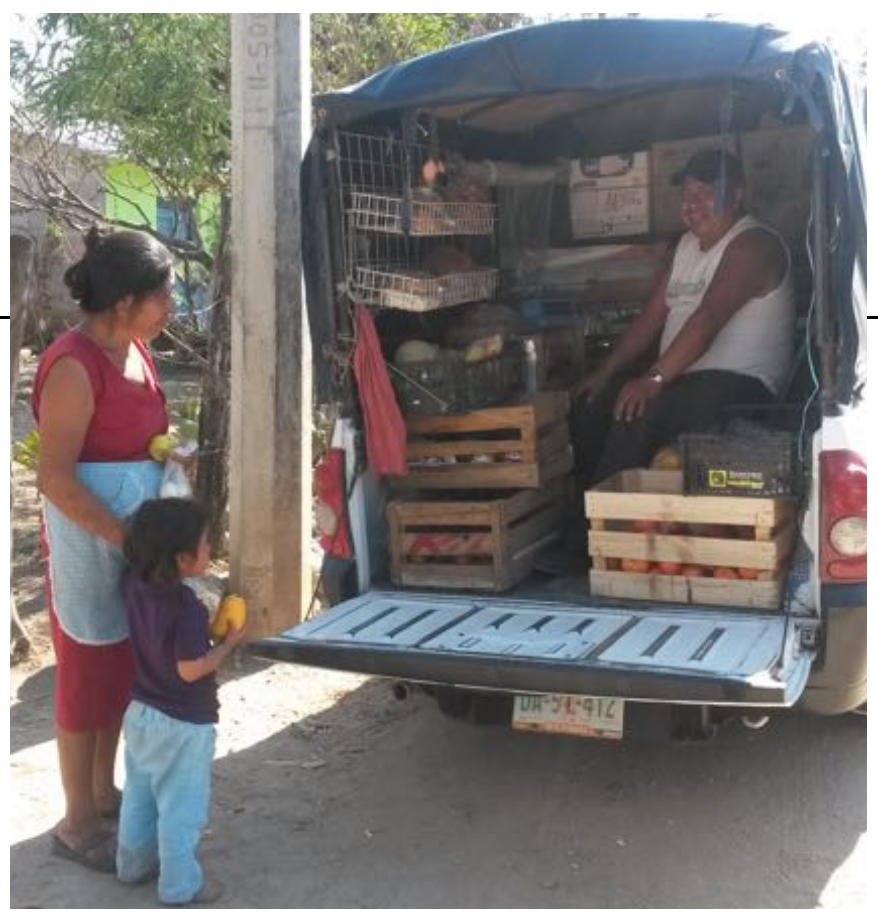

Figure 24. War, drought, and food insecurity: food truck in mestizo community, Venustiano Carranza. Photograph by author.

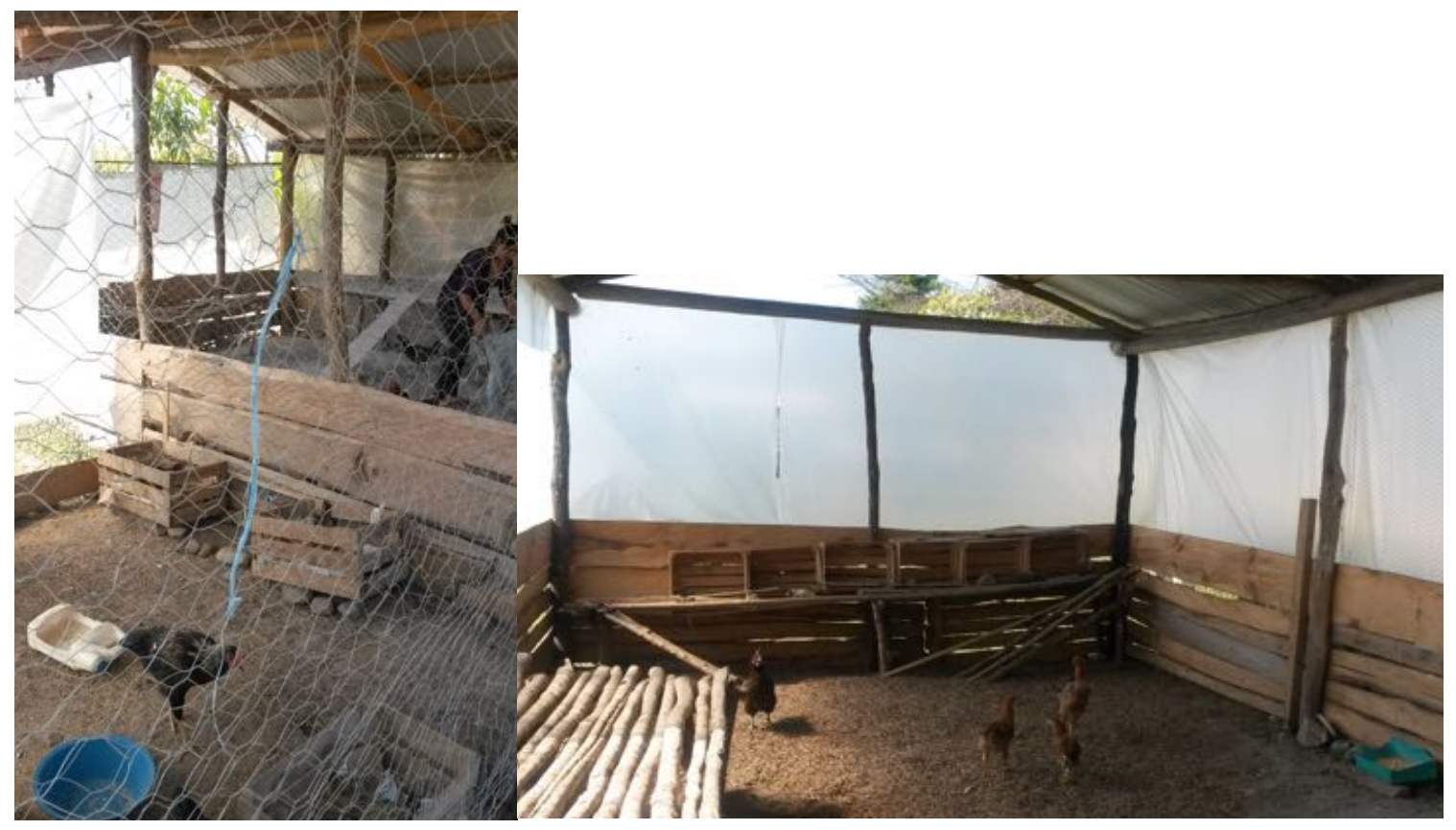

Figure 25. Chicken-raising cooperatives. Left: mestizo community, Venustiano Carranza; Right: mestizo community, Teopisca. Photographs by author. 

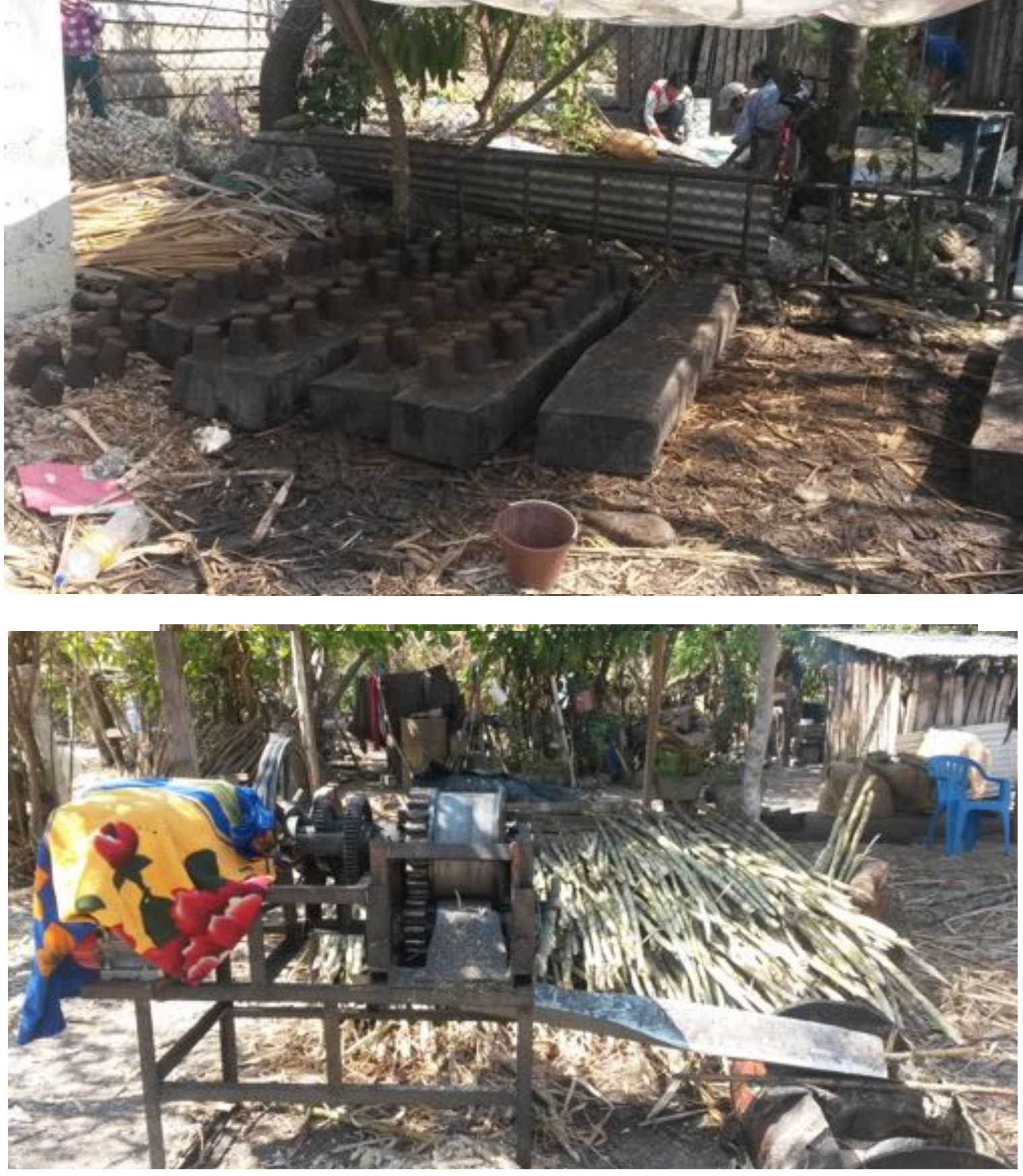

Figure 26. Molasses-production collective, mestizo community, Venustiano Caranza. Photographs by author.

Although the situation in this particular community is extreme, it is not an unknown context for DESMI. These conditions are similar to those in which the 
organization has worked for decades, first in communities that would later join the ranks of the EZLN, and then with the thousands of refugees during the climax of the lowintensity war (1994-2001). DESMI remains confident that if communities organize and work together based on solidarity principles, they can create an alternative to those severe and unfair conditions. For DESMI staff, the EZLN is empirical proof of that premise. As Mariano points out, "it is in communities with those environmental, political, and food insecurity conditions where the implementation of solidarity economy, agroecology, and seed sovereignty projects is more necessary."13

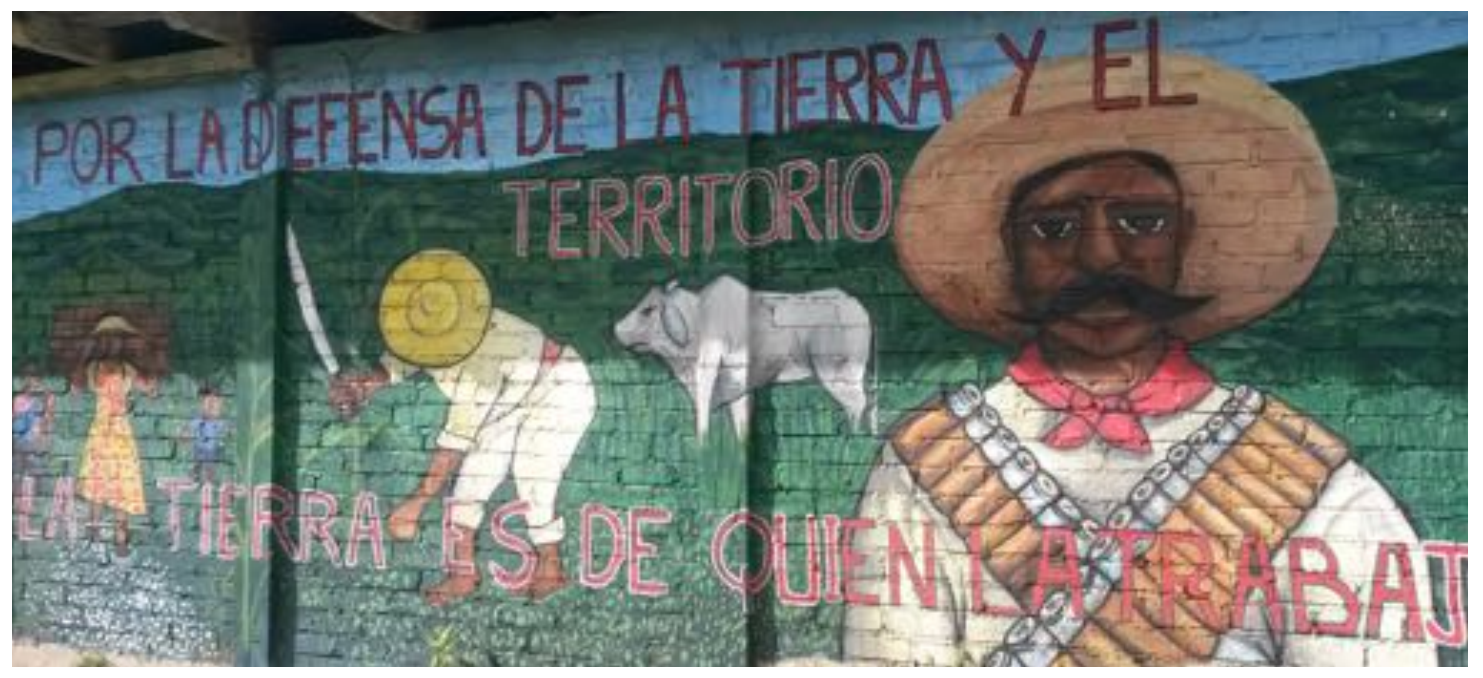

Figure 27. Emiliano Zapata, major leader of the Mexican Revolution of 1910: "The land belongs to those who work it." Community adherent to The Other Campaign, Teopisca. Photograph by author. 


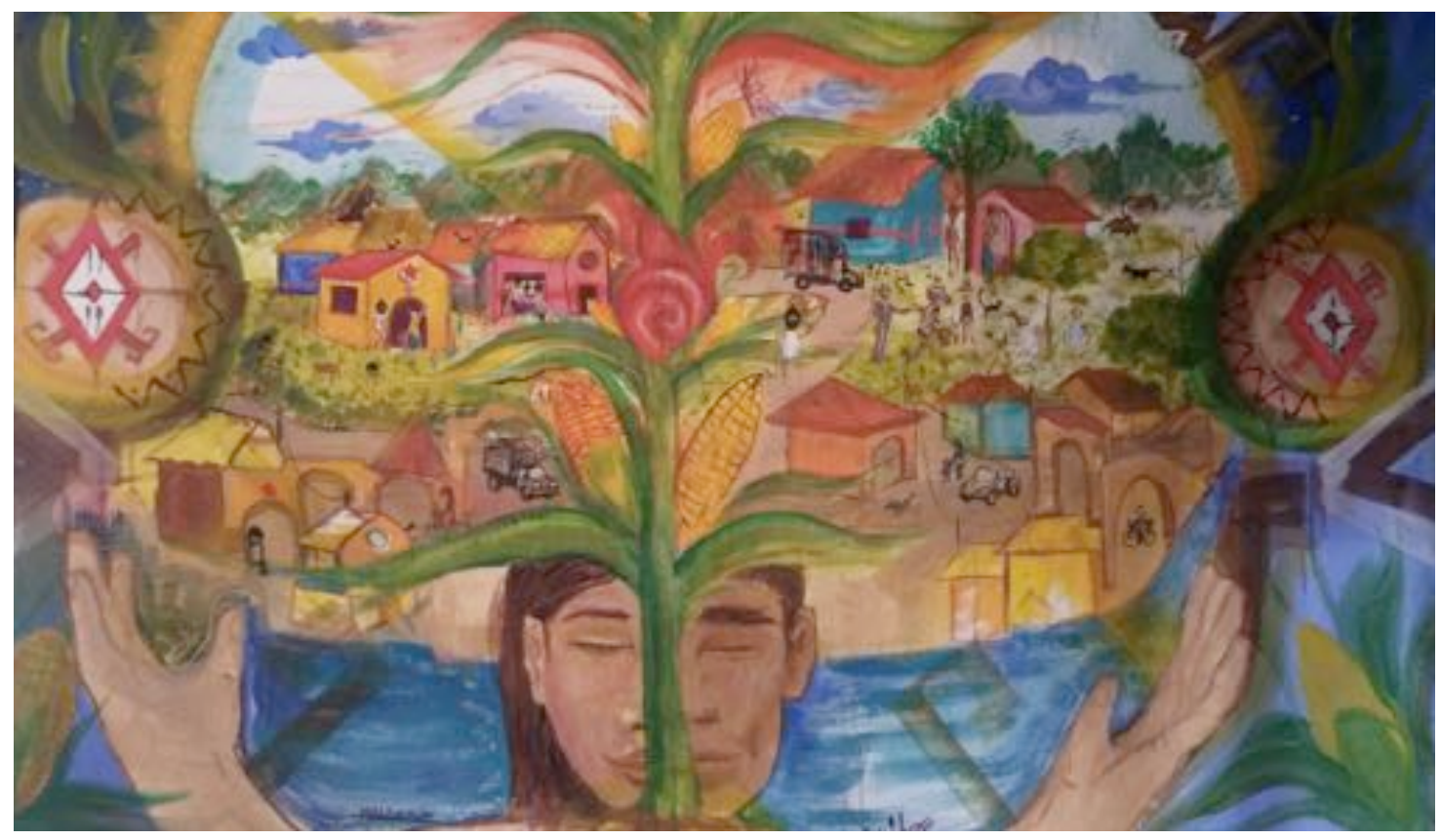

Figure 28. "Lekil Kuxlejal-Ich'el ta muk": the process of building a dignified and harmonious life, in Tseltal and Tsotsil. Mural located in CODIMUJ. Photograph by author.

\section{Conclusion}

To what extent does DESMI's Guardians of Mother Earth and Seeds project contribute to the decommodification of peasant agriculture and to protect native seeds? According to Vail, the phenomenon of decommodification is not limited to preventing or reverting the privatization of the commons (what he terms defensive practices against market encroachments), but it might also encompass:

initiatives that attempt to reverse the destructive aspects of the market by increasing the provision of public goods and by enhancing social protection. It would embrace measures that promote democratic control over the market by creating non-commodified economic circuits that are politically and socially embedded and grounded in a logic predicated on social needs rather than profit. It 
would include efforts to undermine the grip of market hegemony by increasing the transparency of the market and revealing its true social costs and consequences...Decommodification could also generate wider social benefits by ensuring basic needs, enhancing individual capacities and capabilities, promoting social cooperation and collaboration, deepening social solidarity, and improving the social capacity for collective decision making (2010: 312-313).

The practices, projects, and ideas analyzed in this chapter do offer these peasant communities several of the benefits identified by Vail. It is possible to evaluate the contributions of these projects at different levels. Their most tangible contributions are that they enhance the provision of public goods, facilitate the creation of productive collectives aimed at satisfying people's basic needs, strengthen these communities' understanding of their commons, and promote the participation of women in collective decision making.

For example, the creation of seed inventories and seed banks has several benefits in this regard. First, it helps communities to better know their seed systems and define them as protected commons (Kloppenburg 2010). Second, the way the collective process of knowledge generation and transmission around seeds operates allows this educational process to become socially embedded in these communities, because peasants are simultaneously both educators who possess knowledge and transmit it, and learners who receive and internalize new knowledge. This is a basic premise of peasant-to-peasant methods (Rosset et al. 2011). The creation of seed banks also contributes to ensuring communities' basic needs through encouraging the preservation and reproduction of 
biodiversity and the diversification of food production.

In addition to promoting more diversified and healthier diets, the production collectives also offer several other concrete benefits to these communities. For instance, in terms of developing collective capacities and creating non-commodified production circuits, these projects enable collective experimentation with organic methods of production, contribute to training community members, and reinforce the collectivization of labor and productive resources.

These projects also promote the development of solidarity relationships based on cooperation and collective decision-making. Perhaps one of the most far-reaching outcomes of these projects is that they facilitate the participation of women as leaders of the collectives. These projects not only permit women to assume a direct role in the production of food in order to complement households' food needs, but they also promote the collectivization of women's labor. Moreover, through leading these projects, women acquire an important role at the community level in the development and diffusion of agroecological techniques.

Besides promoting the production of extra food, these projects also enhance families' food security in more indirect ways. Among them is the development of a collective consciousness about the importance of adopting a diversified diet based on organic methods of production. DESMI also emphasizes that children, pregnant women, and mothers must have priority in the intake of food within households. Although this idea seems quite obvious, in peasant households it is very common for male members, both adults and children, to have priority over women and girls in the distribution and 
consumption of food. Giving women an important role in the production of food is a good first step toward changing this gender dynamic around food production and consumption. Finally, although these collectives do not resolve many of the structural problems - e.g., land scarcity, soil degradation, climate change — underlying households' limited capacities to produce and consume enough nutritious food, they do offer a minor palliative to the pervasive problem of food insecurity and malnourishment that is prevalent in the region, especially among women and girls.

Another way to evaluate the decommodifying character of these projects is to reflect on whether they effectively counteract some of the developments of industrial agriculture discussed in previous chapters-particularly the increasing commodification of seed systems, the widespread use of agrochemicals, and the displacement of selfproduced food by purchased industrial food.

Regarding seeds, although the increasing enclosure of industrial seed systems does not directly affect these communities, who almost entirely rely on their own native seeds, a key achievement of DESMI's project has been the redefinition of communities' native seed systems as a protected commons. This understanding involves several degrees of action. First, there is a clear delimitation of the regions in which transgenic seeds must not be reproduced in order to prevent the potential contamination and genetic degeneration of native varieties. Following the Zapatista project of seed sovereignty, the Guardians of Mother Earth and Seeds project promotes the designation of indigenous communities as GMO-free zones. Certainly, considering that these communities are already free of most industrial seeds, this is more a political than a pragmatic position. 
However, this declaration effectively reaffirms the dichotomy between privatized industrial seed systems and native seed systems as a protected commons. The impacts of this kind of political stance are better understood in the regional and national context. These communities' clear rejection of GMOs reinforces the national anti-GMO countermovement, which has successfully forced the government to prohibit the production of GM corn in Mexico and GM soybeans in the vicinity of indigenous territories. In this sense, every community that declares itself a GMO-free zone adds to this political countermovement against the biotechnology industry and the transnational corporations controlling it.

Second, this notion of native seeds as a protected commons also implies that communities have the responsibility to protect their native seeds from deterioration, and even destruction, as a result of unsustainable agricultural practices. This understanding entails revalorizing the role that peasant agriculture plays in the protection, reproduction, and evolution of native seed systems. In that sense, this agenda of food and seed sovereignty has successfully made the conservation and evolution of agro-biodiversity an objective per se. This understanding is important because it transcends short-term economic and utilitarian principles and places seed conservation in a broader, and more adequate, conceptual framework: the conservation of ecosystems and the sustainable use of natural resources. It is important to remember that at the time of my fieldwork, these communities were still discussing how they would implement their projects of live seed banks. It will be necessary to wait to see whether communities will effectively engage in the process of seed conservation proposed by DESMI. 
Closely related to agro-biodiversity conservation are the issues of ecosystem restoration and the adaptation of the milpa system to current environmental conditions, including climate change. DESMI has promoted agroecology as a suitable model for advancing those objectives. Although there have been important achievements in training these non-Zapatista peasants in agroecological methods, particularly at the scale of organic vegetable gardens and coffee nurseries, the transition from conventional to organic agriculture in the milpa has not yet been put in motion. Considering the difficulties that Zapatista communities have confronted in this regard, it is logical to expect that these non-Zapatista communities will face similar challenges. It is worth emphasizing that the structural difficulties behind this transition, including scarce and untrained labor, highly degraded soils, and lack of irrigation systems, might indicate that this agroecological model still needs to surpass scale limitations. In fact, the issue of how to bring agroecology and organic agriculture to scale remains one of the most controversial discussions worldwide, particularly because larger scales require different biological knowledge, technical skills, and technology (Altieri and Nicholls 2008, Khadse and Rosset 2017, Snapp and Pound 2017).

These non-Zapatista peasant communities are still only in the very first steps of learning how organic agriculture works at small scales. Indeed, DESMI's staff itself is not yet even technically qualified to scale organic agriculture up to plots of two hectares, which is the average size of the milpa in these communities. Neither do DESMI's training workshops solve the lack of needed technology such as irrigation systems or machines to produce and apply organic fertilizers and herbicides for larger areas of land. 
In the case of the EZLN, the creation of the committees of agroecology, the collectivization of some experimental milpas, and the introduction of a few collectivelyowned machines for producing organic fertilizers are important advances in this regard.

Therefore, the contributions of the Guardians of Mother Earth and Seeds project regarding the transition from conventional to organic agriculture in these non-Zapatista communities are so far limited: it has introduced an alternative method of production and raised awareness about the negative effects of agrochemicals on the environment and human health. Although these contributions are important, in practical terms none of them imply an actual displacement of agrochemicals or processed food. These peasants' diets continue to rely mostly on non-organic subsistence crops and some purchased industrial food. Hence, the effective commodification of these communities' agricultural systems and diets has not yet been fundamentally challenged by these projects.

Finally, there is another important factor that deserves to be considered when analyzing the decommodifying impacts of this project of seed and food sovereignty. I have argued that DESMI's Guardians of Mother Earth and Seeds project has successfully linked, at a cognitive level, several ideas that have contributed to the politicization of seeds and reinforced the dichotomy between subsistence agriculture and the biotechnology industry. Some of these ideas are: (1) that communities need to protect their native seeds against potential privatization and monopolization by transnational corporations such as Monsanto; (2) that communities need to resist the presence of transgenic seeds (Monsanto's seeds, in the words of respondents) within or near their territories in order to prevent genetic contamination; (3) that communities need to protect 
their native seeds from deterioration caused by environmental degradation and semimonoculture; (4) that the use of agrochemicals has greatly contributed to environmental degradation; (5) that agrochemicals, which have also pervasive negative impacts on human health, are controlled by the very same biotechnology corporations that seek to displace native seeds and impose privatized industrial seeds; and (6) that in order to effectively resist the enclosure of seeds and the introduction of GMOs, communities need to unify their efforts against biotechnology corporations, a countermovement that would eventually require the abandonment of agrochemicals.

Not surprisingly, the fact that one corporation-Monsanto—dominates the global market for both industrial seeds and agrochemicals has greatly facilitated the development of a seed sovereignty agenda that is openly opposed to the model of industrial agriculture, overall, that the biotechnology industry is aiming to impose at a global scale. In an attempt to detach from the biotechnology industry, this agenda of seed and food sovereignty has embraced agroecology and organic agriculture as an alternative to the present model of peasant agriculture. The question is whether these non-Zapatista peasant communities will be able to initiate and consolidate this transition.

Taking into account the whole range of initiatives covered in these pages — seed inventories and seed banks, training in organic methods of production, environmental awareness, production collectives, women's rights, households' food security, and the politicization of seeds, among others-I argue that DESMI's Guardians of Mother Earth and Seeds project contributes to the decommodification of peasant agriculture in the region by expanding it based on non-commodified circuits of production. These 
contributions are most tangible in three areas: ensuring basic needs (food, education and training, and infrastructure), expanding the commons (from defining seeds as a protected commons to creating production collectives and community projects), and establishing new and more inclusive spaces where community members can play an active role in the process of collective decision making.

Regarding the decommodification of those areas that are already commodified (the agrochemical milpa and household diets), the contributions of this project are still essentially limited to two aspects: raising awareness about the negative impacts of agrochemicals and processed food on communities, and proposing an alternative method of production. However, as I have discussed, this alternative model (agroecology) still needs to resolve technical limitations in order to be effective. There are also the questions of labor scarcity, the increasing dependence of households on cash income, and the loss of economic relevance of subsistence agriculture in the face of the spread of capitalist food markets. In this regard, one of DESMI's main contributions is to promote the revalorization of subsistence agriculture as an essential mechanism for enhancing communities' food security. I argue that a central contribution of this process of revalorization is the recognition that peasant agriculture in this region as it exists today is no longer sustainable but, if reformed, it could satisfy many of these communities' environmental and food needs. 


\section{CONCLUSIONS}

Seed nevertheless remains the vehicle in which many of the products of biotechnology-GMOs (genetically modified organism) in the current argot-must be embodied and valorized. As both food and means of production, seed sits at a critical nexus where contemporary struggles over the technical, social, and environmental conditions of production and consumption converge and are made manifest.

Jack Kloppenburg First the Seed (2004)

Those who control the seed, control the food

Vandana Shiva (2012)

Since the EZLN in 2002 launched Mother Seeds in Resistance, an anti-GMO initiative focused on agro-biodiversity conservation, the concept of indigenous seed sovereignty has gained political relevance in Chiapas. Sixteen years later, what began as a project limited to Zapatista-controlled autonomous communities has spread to many non-Zapatista communities and other local organizations. Today, seed sovereignty has become one of the most dynamic and powerful political agendas in the region. This is possible, I have argued, because seed sovereignty — a notion rooted in the material, spiritual, and cultural meanings these communities assign to their native seed systemshighlights their common interests as Mayan indigenous people, an identity that transcends political, religious, and territorial divisions. However, as the previous chapters have shown, this confluence around the idea of seed sovereignty is the outcome of an intense process of politicization of seeds in which several actors - Zapatista and nonZapatista communities, local organizations, and activists, social movements, and donor 
agencies from other places in Mexico and the world — have actively participated.

The politicization of seeds, however, is not a phenomenon exclusive to Chiapas, but a worldwide response to the neoliberal enclosure of seeds, agricultural systems, and food markets. The common denominator of this international countermovement is opposition to biotechnology and food corporations and their growing power to shape seed, agricultural, and food systems at a global scale. For activists around the world, GMOs, agrochemicals, intellectual property rights regimes, agribusiness, and the loss of agro-biodiversity have become the most concrete symbols of what the biotechnology and food industries propose as modern agriculture. Monsanto's practices toward consumers, governments, and peasant and indigenous communities around the world reflect the overwhelming power that biotechnology corporations have accumulated under neoliberal globalization (GLP Profiles 2017, Otros Mundos Chiapas 2013, Pietrowsli 2016, Shiva 2017, Siegel and Betz 2016, Tamariz 2013). To mention only one grievance by consumers, there is the firm opposition by biotechnology and food corporations to labeling food containing GMOs. This opposition to labeling might correspond to the fact that, according to the director of a leading grain mill quoted by Kloppenburg, "there's no such thing as certified GMO-free," because of the high degree of cross-pollination between GMO and non-GMO varieties, in addition to weak measures for separating seeds and grains (2004: 302, 317). Studies testing foods labeled as GM-free have been carried out in several countries including Mexico, the U.S., and those of the European Union, and they have systematically found that most "GM-free" foods contain transgenic traces - a revelation the industry would prefer to avoid (Callahan and Kilman 2001, 
González-Ortega et al. 2017, Strom 2015). This fact means that consumers do not have full control over the food they are eating. A parallel situation is that experienced by peasant communities in Mexico whose crops and products suffer from genetic contamination (e.g., maize in Oaxaca, honey in the Yucatan Peninsula) coming from neighboring GM plantations or unlabeled commercial grains. Both consumers and peasants have been confronted with the fact that there are essentially no effective mechanisms to regulate transnational food and agricultural corporations regarding GMOs.

In Chiapas, as in many other parts of the world, the concept of seed sovereignty was originally formulated in opposition to this transnational corporate power (Kloppenburg 2004, 2014, Siegel 2016). This political stance was concretized in civil society resistance against GMOs and, in Chiapas—similar to many other peasant communities in the global South (Camou Guerrero 2015, Navdanya 2018a, Shiva 2018, Siegel and Betz 2016) —also in favor of preserving native agro-biodiversity. Over the years, however, this local agenda of seed sovereignty has progressively evolved into a rich and complex decommodification project that is reinterpreting native seeds and subsistence agriculture as a protected commons. This framing makes explicit the responsibility of peasant communities to protect their native seeds and subsistence agriculture both from external potential threats (privatization and genetic contamination) and from agricultural practices employed by peasants in the region that inadvertently put at risk the sustenance of native seed systems (agrochemical near-monoculture, deforestation). Thus, in an attempt to preserve their native seeds, these communities have 
initiated a process of transforming their own subsistence agricultural practices.

Focusing on DESMI's Guardians of Mother Earth and Seeds project, this ethnographic research sheds light on how specific political agendas originate and evolve in the region. What is unique about this project in non-Zapatista communities is that it is the synthesis of three political projects: (1) DESMI's model of solidarity economy, (2) the EZLN's indigenous autonomy project, and (3) the diocese's anti-neoliberal political agenda that brings together elements from the liberation and Mayan theologies and from Pope Francis' Encyclical Letter. The particularities of this project allow a rich comparison between what seed sovereignty looks like in practice in Zapatista and nonZapatista communities.

Despite structural differences between Zapatista and non-Zapatista communities (including their long-term political goals and institutional and organizing capacities), they have nonetheless managed to establish as a common ground the idea of native seeds and subsistence agriculture as a protected commons. What makes this understanding so appealing for communities in the region is that it echoes the enduring pre-capitalist social relations that are inherent to them. Although indigenous communities in Chiapas have been immersed in the dynamics of the capitalist system since colonial times, they have nonetheless preserved many of their pre-capitalist social relations. The reproduction of pre-Columbian elements such as subsistence agriculture, the milpa system, native seeds, collective land ownership and labor arrangements, languages, and spiritual rituals and beliefs reflects the centrality that non-commodified social and economic structures still have in these communities. The notion of seeds and subsistence agriculture as a protected 
commons is powerful precisely because it proposes to protect and expand the noncommodified structures that are essential for the social reproduction of these communities. This conceptualization is what gives the political project of seed sovereignty its decommodifying character.

This local project of decommodification around the idea of seed and food sovereignty should be interpreted as a concrete expression of the long-term process of self-redefinition and internal transformation of indigenous communities in Chiapas that began several years before the Zapatista uprising in 1994. The EZLN is, without a doubt, the key protagonist of the indigenous movement in Chiapas; however, it is only one of the many actors who make it possible. Interpreting the indigenous movement as a spectrum, on which the Zapatista project is its most fully-developed expression, is useful for understanding why DESMI's seed and food sovereignty agenda has been so easily translated from Zapatista communities to non-Zapatista communities. This proposal of seed and food sovereignty is situated on the common terrain of the indigenous movement, which is composed of the Mayan identity and the historical idea of an indigenous autonomy that is rooted in those non-commodified structures that have sustained indigenous people for centuries.

This dissertation opened with three questions: (1) How do the increasing industrialization and commodification of seed systems and agriculture affect peasant communities in Chiapas? (2) How is the local seed and food sovereignty countermovement responding to those processes of commodification? And (3) How does this case study contribute to understanding the relationship between capital's tendency to 
enclose the commons and the protective countermovements that attempt to resist such market encroachments? In the following section I summarize the key findings and arguments of this research, and then briefly discuss some other relevant topics developed in the preceding chapters.

\section{Key Findings}

\section{Commodification and Deterioration of Subsistence Agriculture}

This study refutes the belief that exists among members of the seed sovereignty movement, both in Chiapas and other parts of the world, that privatization is one of the primary risks that the neoliberalization of agriculture poses to native seeds. Instead, I found that one of the most significant risks to the preservation and reproduction of native seeds is the deterioration of peasant agriculture. Three main factors have converged in this outcome: the neoliberal dismantling of the public institutions supporting peasant agriculture; the increasing commodification of peasants' diets and labor, and the consequent displacement of self-produced food by purchased food; and the reproduction of agricultural practices that exacerbate environmental deterioration and further undermine communities' ability to reproduce subsistence agriculture. Stemming from this observation, a prediction of this research is that if subsistence agriculture continues to lose relevance for the social reproduction of these communities, the incentive to reproduce native seeds will be reduced as well.

The deterioration of subsistence agriculture in the region is reflected in the gradual abandonment of the milpa —a complex agroforestry system—and its replacement by an agrochemical near-monoculture of maize and beans, intensified agricultural 
practices, and introduction of livestock. This process of "minimization" of the milpa has allowed peasants to keep reproducing subsistence agriculture while increasingly participating in the labor market. However, this model of agriculture has had several negative impacts on the environment, biodiversity, and human health. According to respondents, environmental degradation caused by the use of agrochemicals is a key factor explaining the decrease in productivity of the milpa. This phenomenon has, in turn, reinforced households' dependence on external food markets for complementing selfproduced food.

One of the most direct impacts of Green Revolution policies in these communities has been the chemicalization of peasant agriculture. Paradoxically, although these communities never adopted commercial seeds - the key input of the Green Revolution technological package — they did adopt the agrochemicals that accompanied those seeds. This process of chemicalization has had three important implications for these communities: (1) the partial commodification of subsistence agriculture, which is reflected in peasants' dependence on industrial inputs; (2) the degradation of the environmental conditions that make possible the reproduction of subsistence agriculture; and (3) the deterioration of human health as a result of both direct exposure to agrochemicals and consumption of non-organic food.

This case study paints a more nuanced picture of what the food sovereignty movement (and the mainstream literature analyzing it) present as the model of peasant agriculture - "the peasant way," in the words of La Via Campesina, as the basis of a sustainable and socially just food system—particularly when its virtues are highlighted in 
contraposition to the neoliberal agri-food system (Bernstein 2014, Desmarais 2015, LVC 2017, 2018a, McMichael 2014, Shiva 2016). Peasant agriculture, at least in this study region, is not synonymous with organic production, sustainable agricultural practices, or households' food security. These are still promissory goals of the food sovereignty movement and the agroecological model, not a concrete reality. What predominates today in this region is a triple model of agriculture in which traditional, organic, and conventional methods of production coexist side by side. Likewise, although subsistence agriculture continues to be the fundamental source of food for these communities, it is unquestionable that it has lost economic importance as households have become more dependent on cash markets for their social reproduction. Moreover, environmental degradation and climate change have further undermined these communities' capacity to reproduce subsistence agriculture. These issues illustrate the scale of the challenges that the seed and food sovereignty movement has to overcome in order to succeed.

\section{Seed and Food Sovereignty as Decommodification}

A key proposition of this research is to conceptualize the seed and food sovereignty agenda as a project of decommodification. This project is composed of three elements: to enhance and expand the commons, to reverse commodification, and to limit new market encroachments. Empirically, these elements are concretized in three overall objectives that are present in both DESMI's Guardians of Mother Earth and Seeds project and the Zapatista agenda of food and seed sovereignty: to reduce communities' dependence on cash markets by reinforcing and expanding subsistence agriculture based on agroecological methods of production, to limit environmental degradation and agro- 
biodiversity loss, and to protect seeds and subsistence agriculture from further deterioration and from potential external threats such as seed and land enclosure or seed genetic contamination.

The development of these three elements is uneven. The most advanced aspect of this project is the reinforcement and expansion of the commons at the community level, which is concretized in the partial collectivization of food production and the implementation of specific initiatives for agro-biodiversity conservation. Regarding the protection of the commons from new market encroachments, the main outcome of this project is that it has introduced in these communities the idea of seed and food sovereignty, which has led to the redefinition of subsistence agriculture and native seeds as a protected commons. This process has entailed the revalorization of subsistence agriculture and native seeds as fundamental elements of these communities' social and cultural reproduction. More importantly, this redefinition has emphasized the role that peasants play in the reproduction and protection of the commons. Enhancing subsistence agriculture and protecting agro-biodiversity are concrete measures through which these communities can prevent the further deterioration of subsistence agriculture in a neoliberal context that favors the integration of peasants into cash markets.

The dechemicalization of subsistence agriculture is one of the main unfulfilled goals of this project. This outcome indicates the great difficulty of reversing commodification once it has taken place. Although DESMI and the EZLN have made some important advances concerning the development of organic methods of production at small scale (e.g., collective organic vegetable gardens, coffee plots, honey production), 
the transition from conventional to organic agriculture in the milpa remains limited to some exceptional cases. Not surprisingly, I found that making the transition to organic agriculture in the milpa is easier for those communities that have good-quality soils, access to water, and are better organized, which is the case for the communities that have been recently formed on seized ex-finca land. This finding highlights the importance of having access to good quality resources — which is not the case for most indigenous communities in this region — and highlights the need to adjust the agroecological model to the conditions of communities with a higher degree of ecological marginalization. I would argue that the structural impacts of this agroecological project will remain limited until organic agriculture fully reaches these communities' primary source of food-that is, the milpa.

The story of DESMI illustrates that attempts to reverse communities' dependence on agrochemicals go back to the early 1980s, shortly after agrochemicals were first introduced among these peasant communities by the Mexican government as part of the Green Revolution. This fact suggests that there is a long-term, unresolved tension in these communities between traditional and industrial models of agriculture. It is important to highlight this issue in order to refute the idea that peasants are inherently opposed to Green Revolution technologies, which seems to be a presumption of the international food sovereignty movement (Desmarais 2015, LVC 2018a, Martínez-Torres and Rosset 2010, McMichael 2014, Navdanya 2018b, Shiva 2005, 2016). Peasants use agrochemicals because they help to partially resolve some of the constraints (e.g., labor and land scarcity, degraded and inadequate soils for agriculture) that they face in keeping 
subsistence agriculture as the main source of their food. It is undeniable that the concept of agroecology has gained influence as peasant communities affiliated with the EZLN have embraced environmental sustainability and adaptation to climate change as key priorities of their programs of environmental governance. However, this agroecological model needs to be further developed in order to fully displace agrochemicals and thus reverse the commodification of subsistence agriculture.

\section{Seed Privatization and Peasant Agriculture}

As I stated earlier, key protagonists in the seed sovereignty movement hold a strong conviction that privatization is one of the main risks that the neoliberalization of agriculture poses to native seeds (CECCAM 2009, GRAIN 2015, LVC 2013). This perception has been reinforced by the privatization of public breeding institutions all around the world, and the implementation of international and national legal frameworks regulating intellectual property rights over germplasm and seed certification (De Schutter 2009, Golay 2016, Kloppenburg 2010, 2014). The argument goes that these processes threaten peasant seed sovereignty by privatizing public research and gemplasm, in the case of IPRs, and by outlawing the practices that are necessary for the reproduction of informal seed systems, in the case of seed certification laws (GRAIN 2009, Shiva 2009, Wattnem 2016). These regulations are perceived as mechanisms of accumulation by dispossession (Wattnem 2016), which means that they favor the expropriation from peasants of their means of subsistence, in this case seeds.

I have argued that the impacts of these measures on native seeds are not so straightforward, essentially because they are aimed at regulating the functioning of 
formal (industrial) seed systems and markets. Therefore, peasants who are affected by such regulations are those who already purchase and sow commercial seeds. Native seeds, which constitute the main component of informal seed systems and are the foundation of subsistence agriculture in the global South (Badstue et al. 2007, FAO 2010), are almost entirely outside of these regulations. In the particular case of Mexico, contrary to popular belief, the 2007 Federal Law on Production, Certification, and Commercialization of Seeds does not address native seeds (Government of Mexico 2007). These misunderstandings reflect the lack of clarity about the limits between formal and informal seed systems, which is understandable considering the historical complementarity that had existed between them until the 1990s (Louwaars et al. 2013, Réseau 2011).

Since then, however, the industrial seed sector has gone through an intense and rapid process of consolidation and privatization by a few biotechnology corporations. The enclosure of industrial seed systems has been reinforced by the elimination of exemption rights for peasants and researchers over the use of protected varieties (improved, hybrid seeds), and also by the development and release of novel technologies that are patented (i.e., GMOs) (De Schutter 2009, Golay 2016). As the case of Mexico under NAFTA exemplifies, "free trade" agreements regulating agriculture have, in turn, forced the liberalization of national agriculture, seed, and food systems and their incorporation into global industrial markets (Appendini 2014, Barry 1995, Eakin et al. 2014a, Harvey 2005, McMichael 2016a, Wise 2009), which entirely rely on industrial seeds and to great extent on the biotechnology industry (Dalton et al. 2010). ${ }^{1}$ The process of standardization of 
those global markets has required the adaptation of national agricultural systems to international norms and standards, which has been achieved in part through the adoption of common technologies (seeds, agrochemicals, and other technological inputs) (Appendini 2014). Considering the unequal conditions of international trade between the global North and South, this process of homogenization has entailed the adoption by the global South of the technologies developed and controlled by corporations based in the global North (Otero 2012a, Pechlaner and Otero 2010).

The liberalization of agriculture has also demanded the restructuring of national production and consumption systems in line with the demands of global markets (Appendini 2014, Eakin et al. 2014a). In an attempt to expand and consolidate those markets, it has been necessary to dismantle alternative systems of production, commercialization, and consumption. State-controlled markets and peasant agriculture (including native seeds) have represented two of the main obstacles to the expansion of those global markets (Appendini 2014, Bello 2009, Eakin et al. 2014a). In order to overcome these barriers, neoliberal reforms aimed at dismantling the public sector in agriculture have been implemented since the 1980s (Bello 2009, Harvey 2005, McMichael 2016a). One of the main consequences of this neoliberal restructuring has been the elimination, one by one, of most of the institutional supports for peasant agriculture — protected markets for peasant production, subsidized food, technological inputs and training, infrastructure and services, and agrarian reform. Through this process, peasant agriculture and native seeds have been almost entirely relegated to the realm of subsistence agriculture, as well as sporadic surpluses for small local markets 
(Barry 1995, Bello 2009, Yúnez-Naude 2003).

From this analysis, it is possible to conclude that the privatization and corporatization of global industrial seed systems does indeed have an impact on native seeds. However, this impact is not the direct privatization of native seeds, but rather their exclusion from formal markets and their relegation to subsistence agriculture.

Furthermore, as I discussed earlier, one of the many consequences of the neglect of peasant agriculture has been the deterioration of subsistence agriculture, which, I argue, is the most immediate risk that the neoliberalization of Mexican agriculture poses to native seeds.

This discussion adds complexity to the analysis of how the dynamics of expanded reproduction and accumulation by dispossession have converged in the process of the commodification of seeds and the expansion of global industrial markets that are dominated by a few transnational corporations. Understanding how these different dynamics of capital accumulation work together, and how they affect these communities' subsistence agriculture, helps to better comprehend the intricate ways in which global processes such as the industrialization and commodification of agriculture and seeds shape local spaces.

As this research highlights, the capitalist displacement of peasant agriculture in Mexico under NAFTA is a process that strongly relies on accumulation by dispossession. More than the development of novel technologies (industrial seeds and their technological packages) and efficient global markets, it has been the power of the Mexican state, within the framework of international organizations (IMF, World Bank, 
and WTO) and their schemes of global governance, which has displaced peasant agriculture and opened new markets for capital accumulation where those novel technologies can be used and further developed.

\section{The Political Discourses of Seed Sovereignty}

The local project of seed and food sovereignty can be analyzed on two complementary levels. The first is a political, external level on which peasant communities are contesting, from a discursive platform, the neoliberal dynamics of capital accumulation that threaten peasant agriculture. The second is an affirmative, internal level, on which communities are implementing concrete measures for strengthening subsistence agriculture and reducing their vulnerability to neoliberal capital accumulation.

It is on the political level where the EZLN and DESMI have positioned indigenous communities in Chiapas as part of broader national and global social movements that oppose the neoliberalization of agriculture and food systems. The redefinition of native seeds and subsistence agriculture as a protected commons, the declaration of indigenous communities as GMO-free zones, opposition to federal laws regulating seeds and to liberalization of the national maize market, and the embrace of agroecology as "the peasant model" of agriculture are some examples of how this local project of seed and food sovereignty has been translated into concrete political agendas. Almost all of these local agendas reproduce some propositions and ideas coming from other social movements and civil society initiatives, both at the national and international levels. 
I identify four external agendas that converge in DESMI's project of food and seed sovereignty. The first is that of the international peasant movement La Via Campesina (LVC), whose definition of food sovereignty asserts the right of peasant communities to develop subsistence agriculture based on sustainable methods of production (LVC 2018a). Indeed, since this concept was launched in 1996, the political discourse of the international food sovereignty movement has practically equated agroecology with peasant agriculture - agroecology as "the peasant way," in the words of LVC (LVC 2018b). Seen from this ideological framework, peasant agriculture is inherently opposed to the Green Revolution model (McMichael 2014, Shiva 1991, 2017).

The second political agenda comes from the anti-biotechnology movement (Schurman and Munro 2010). Over the years, it has evolved into a global anti-GMO movement that contests the power that biotechnology and agri-food corporations have gained under neoliberalism, which is reflected in their overwhelming power to define agricultural and food systems at an international scale (Camou Guerrero 2015, Kloppenburg 2004, 2010, 2014, Schurman and Munro 2010, Siegel and Betz 2016). This movement has triggered a set of initiatives that range from promoting organic agriculture, to labeling GM food, to increasing the power of citizens to regulate biotechnology and food corporations.

The third political agenda is framed in the concept of national food sovereignty, which in the last two decades has gained relevance in international fora such as the FAO (Pritchard et al. 2016). This agenda focuses on the risks that "free trade" rules pose to national food security and agricultural systems, mainly in the global South. In Mexico, 
the national civil society campaign Sin Maiz No Hay País summarizes many of these arguments (Sin Maíz No Hay País 2008). So far, one of the main achievements of this campaign has been the revalorization of native maize, as opposed to imported U.S. transgenic corn.

Finally, the fourth and newest political agenda is seed sovereignty, which emerges from the confluence of these three political programs (Kloppenburg 2010, 2014). In broad terms, the idea of seed sovereignty opposes the enclosure of seeds by biotechnology corporations, the spread of monoculture agribusiness that threatens agrobiodiversity, and the displacement of native seeds by industrial seeds. It also reaffirms the right of peasant communities to preserve, reproduce, and exchange their native seeds based on non-commodified relationships (Kloppenburg 2014, LVC 2013, Navdanya 2018a, OSSI 2018).

DESMI's food and seed sovereignty project synthesizes these various external political agendas and merges them with the political projects of the EZLN and the diocese of San Cristóbal. This case study shows how deeply interconnected these local, national, and global spaces are, and how concrete political projects can emerge from the confluence of different social movements and the particularities of local spaces.

An important contribution of this political dimension of food and seed sovereignty is that it helps, in Vail's words, to "undermine the grip of market hegemony by increasing the transparency of the market and revealing its true social costs and consequences" (2010: 312). DESMI and the EZLN have been consistent in their efforts to generate a collective understanding of the costs for indigenous communities of being subordinated 
to the dynamics of capitalist markets. This understanding has been useful on two fronts: first, it has helped to reinforce the notion of subsistence agriculture, native seeds, and communities' ecosystems as a protected commons that must be fenced off from market encroachments to prevent their destruction; and second, it has helped communities to realize the current degree of deterioration of subsistence agriculture, ecosystems, and people's health. According to this political discourse, such deterioration is a result of the commodification of subsistence agriculture and of peasants' diets and labor. Following this logic, in order to reverse this damage, communities need to detach from capitalist markets and reinforce their non-commodified economic and productive circuits of social reproduction.

However, some of the assertions that DESMI and other local organizations have presented to indigenous communities are not entirely accurate. Some of those ideas are that the privatization of communities' native seeds is a major risk posed by neoliberal reforms; that the federal law on seed certification outlaws the practices that sustain the reproduction of native seed systems; that this law reflects Monsanto's desire to privatize native seeds and to introduce GMOs in indigenous territories; and that Monsanto wants communities to be dependent on its agrochemicals, which destroy communities' biodiversity and people's health. Most of these arguments, in fact, correspond more to the political discourses of international social movements than to the concrete local reality. Nevertheless, those discourses have contributed greatly to the political mobilization of indigenous communities in Chiapas around ideas of seed sovereignty.

More importantly, this political, discursive dimension of DESMI's food and seed 
sovereignty agenda has helped to define some of the affirmative internal elements of its project of decommodification. The introduction of agroecological methods of production, the creation of food production collectives and cooperatives, and the implementation of programs focused on agro-biodiversity conservation and reforestation are examples of how those political agendas have been translated into concrete community-based projects. As I discussed in chapters 5 and 6, such initiatives do indeed strengthen subsistence agriculture and reduce communities' vulnerability to neoliberal capital accumulation. These initiatives offer social protection to these peasant communities by enhancing their food security, creating non-commodified productive circuits that are based on social needs rather than profit, promoting the preservation of biodiversity, and improving the environmental conditions in which peasants live. Taking together both the political/external and the affirmative/internal dimensions, DESMI's project of food and seed sovereignty encompasses all of the five elements of decommodification identified by Vail: boundary protection, public goods provision, socially embedded circuits, social protection, and market transparency (2010: 313).

\section{Contextualizing Food and Seed Sovereignty} in the Zapatista Project of Indigenous Autonomy

The Zapatista project of food and seed sovereignty has its roots in the historical struggle of indigenous peoples for land and other productive resources in Chiapas. According to Howard (1998), this struggle is a response to the ecological marginalization imposed on indigenous communities in Chiapas by an evolving class of elites dating back to the colonial regime. From a world-systemic perspective, Gunderson (2018) argues that 
the particular timing of the major indigenous revolts that have taken place in Chiapas since the 16 th century was determined by changes in systemic cycles of capital accumulation. As this research shows, the emergence of the contemporary indigenous movement in Chiapas closely coincides with the rise of the neoliberal agri-food system beginning in the mid-1970s.

The literature on food regimes emphasizes that the configuration of global capitalist agricultural systems requires the continual restructuring of the agricultural systems of the Third World—including the dismantling of non-commodified forms of production - and their articulation to the industrialized food systems of the global North. Green Revolution policies, "free trade" treaties incorporating agriculture, intellectual property rights regimes, and the forceful dismantling of peasant agriculture under the mandate of structural adjustment programs are some of the key features that define the relationships between the global North and South under the neoliberal food regime (Araghi 2010, Bernstein 2016, Friedmann 2016, McMichael 2016a, 2016b, 2014, Otero 2012a, Pechlaner and Otero 2010, Pritchard et al. 2016).

The Zapatista project of decommodification can be better understood when analyzed in this macro-structural context, where novel dynamics of capital accumulation coincide with old structures of socio-economic stratification that have their origins in the colonial regime. Emanuel Gómez, from the University of Chapingo in San Cristóbal, suggested during our interview that the Zapatista project of indigenous autonomy can be depicted as a four-stage process of re-appropriation. ${ }^{2}$ The first stage (1983-1993) was the re-appropriation of an ideological revolutionary discourse that allowed a mass of young 
landless indigenous peasants to form a guerrilla force and to create the conditions for implementing their own agrarian reform. The second stage (1994-2003), beginning with the uprising, was the armed re-appropriation and defense of land and other productive resources. The third stage (beginning in 1994, but deepened in August 2003) has been the re-appropriation of the territory, which is being realized through the implementation of the EZLN's system of autonomous government. Finally, the fourth stage (since August 2003) has been the re-appropriation of the methods and means of production, reflecting a rejection of the Green Revolution model of agriculture and the adoption of agroecology as the axis of the Zapatista agricultural system, which corresponds to the EZLN's project of food sovereignty. ${ }^{3}$

According to Gómez, "this fourfold process of re-appropriation is what has allowed the EZLN to consolidate in material form its agenda of indigenous autonomy...Without the re-appropriation of the means of production and other resources that are essential for the survival of indigenous communities, it would have been impossible to advance the Zapatista project. It was necessary for the EZLN to contest the prevailing power relationships by breaking down the monopoly by local elites over the means of production." ${ }^{4}$ As Gómez's description suggests, the Zapatista project of indigenous autonomy is itself a project of decommodification that has evolved from an initial stage of "repossession" of the commons, as Kloppenburg puts it (2010), to the effective creation of an autonomous system for governing them.

This conceptualization of the Zapatista movement is useful for better contextualizing DESMI's food and seed sovereignty agenda as part of a broader project 
of decommodification that has its roots in the historical, anti-colonial struggle of indigenous peoples to recover their lands and other productive resources that local and national elites had expropriated from them since colonial times.

\section{Contributions}

This ethnographic case study expands the literature on the political economy of seeds and, more broadly, on the political economy of agri-food systems, by illustrating how indigenous communities contest both conceptually and in practice the dynamics of capital accumulation that threaten native seeds and peasant agriculture, as well as their own survival as people who live from the land. It also helps to operationalize both theoretically and empirically the concept of seed sovereignty as decommodification, including the redefinition of native seeds and subsistence agriculture as a protected commons. It also establishes a distinction between the political/external and affirmative/internal dimensions of seed sovereignty.

Regarding the literature on the Zapatista movement, this research contributes to several lines of analysis. The most important is the issue of the political relationship between Zapatista and non-Zapatista communities and how regional political agendas emerge from the collaboration between them. I emphasize the role that local and external organizations play as bridges of communication between both types of communities. This is likely the first ethnographic study analyzing the impacts that the Zapatista project of indigenous autonomy has on non-Zapatista communities, including the adoption by the latter of political projects that were originally developed by the EZLN. I argue that this transmission of political agendas from Zapatista to non-Zapatista communities is a 
tangible example of the hegemony that the EZLN has attained in the region.

This dissertation also contributes to the scholarship on the EZLN's model of indigenous autonomy, by focusing on the area of agroecology. There are several studies analyzing the Zapatista systems of education, health, and autonomous government (Barmeyer 2009, Baronnet 2009, Baronnet et al. 2011, Cuevas 2007, Zaga 2015). The topic of gender and women's rights has also been extensively studied (Forbis 2011, Klein 2015). However, the area of agroecology, which is one of the key axes of the Zapatista project, has been practically neglected by researchers. Focusing on DESMI, I have contributed to tracing the origins and evolution of this agroecological model. The preceding chapters show that the project of strengthening subsistence agriculture as a mechanism for reinforcing communities' autonomy is as old as the Zapatista movement itself. They also highlight the importance that solidarity markets for organic products (primarily coffee and honey) have had in the development of organic agriculture in the region. This finding is relevant because it indicates the importance that consumers and activists in the global North who support solidarity markets might play in spreading organic agriculture in peasant communities in the global South.

One of the purposes of this dissertation was to identify and analyze some of the challenges the indigenous movement in Chiapas has to confront in order to advance its decommodification and anti-capitalist agenda. I have argued that the decommodification of agriculture and food, and underlying it, the decommodification of nature, is a project that deserves to be pursued.

This analysis also contributes to understanding some of the dynamics of the 
capitalist system that governs agriculture today. Although these peasant communities are apparently situated outside of the norms of industrial agriculture, essentially because they are focused on subsistence agriculture, this dissertation demonstrates that the capitalist system has indeed permeated peasant agriculture in several major ways. The widespread use of agrochemicals, the partial abandonment of subsistence agriculture in favor of cashgenerating activities, and the commodification of diets through the adoption of purchased industrial food, are some elements that show the degree to which these communities are immersed in the dynamics of capitalism.

The decommodifying, anti-capitalist potential of seed and food sovereignty lies primarily in its capacity to reverse some of the commodification processes discussed above. This decommodification agenda requires the proposition of viable and sustainable alternatives to the current model of peasant agriculture, and to the pervasive problems of food insecurity and environmental degradation that persist in peasant communities in Chiapas. As I have discussed extensively, the challenges that communities must overcome in order to build and sustain such alternatives are immense. However, I believe that DESMI and the Zapatista movement are advancing in the correct direction because they have identified as a key goal of their agendas the decommodification of nature, and, central to it, the decommodification of agriculture and food production. This dissertation aims to contribute to that process of reflection and transformation. 


\section{NOTES}

\section{Introduction}

${ }^{1}$ In 2014, the "Oregon Right to Know" campaign, a non-partisan grassroots ballot initiative to require labeling food in grocery stores produced through genetic engineering, was narrowly defeated in Oregon's November $4^{\text {th }}$ general election by just 812 votes, out of more than 1.5 million cast. This grassroots initiative generated a corporate-funded antiGMO-labeling campaign, the "No on 92 Coalition", which raised \$20.8 million. All donations were corporate contributions, and all of them came from outside of Oregon. The main donors were Monsanto, Pepsico, Mead Johnson and DowAgroSciences (see: https://www.facebook.com/oregonrighttoknow/

\section{Chapter One}

${ }^{1}$ Since grain grows near the top of plant, heavy grain yields would make the plants topheavy and would induce them to fall over. This problem is known as "lodging" (Gollin et al. 2016: 9).

${ }^{2}$ Hugo Perales, personal communication, 2016.

${ }^{3}$ Juan, interview, San Cristóbal, 2015.

${ }^{4}$ Ibid.

${ }^{5}$ Elinor Ostrom, Nobel Prize: http://www.nobelprize.org/nobel_prizes/economicsciences/laureates/2009/ostrom-facts.html

${ }^{6}$ According to Ostrom, "the term "common-pool resource" refers to a natural or manmade resource system that is sufficiently large as to make it costly (but not impossible) to exclude potential beneficiaries from obtaining benefits from its use" (1990: 30).

${ }^{7}$ The CPR is itself located within one country and the number of individuals affected varies from 50 to 15,000 persons who are heavily dependent on the CPR for economic returns (Ostrom 1990: 26)

${ }^{8}$ Ostrom proposed eight principles for designing sustainable CPR self-governed institutions: (1) the boundaries of a resource system, as well as the individuals or households with property rights, are clearly defined; (2) rules are used that allocate benefits proportional to the inputs that are required; (3) collective-choice arrangements through which most of the individuals affected by a resource regime are authorized to participate in making and modifying their rules; (4) monitoring and enforcement of the rules; (5) graduated sanctions; (6) conflict-resolution mechanisms which must be rapid, low-cost, and local; (7) minimal recognition of rights to organize by external governmental authorities; and (8) for CPR that are parts of larger resource systems, a nested hierarchical structure of decision making for governing activities that are organized in multiple layers; this permits governing the interdependencies among smaller units (1990: 90, 2008).

${ }^{9}$ Ibid.

${ }^{10}$ OSSI, “About."

${ }^{11}$ Federal Law on Plant Varieties, 1996:

http://www.upov.int/upovlex/en/text.jsp?file_id=224281 
${ }^{12}$ Federal Law on Biosecurity of Genetically Modified Organisms, 2005:

https://www.loc.gov/law/help/restrictions-on-gmos/mexico.php

${ }^{13}$ Federal Law on the Production, Certification and Trade of Seeds, 2007: http://www.wipo.int/wipolex/en/text.jsp?file id=200406

${ }^{14}$ To discuss the concept more formally and democratically, La Via Campesina organized two major international conferences on food sovereignty: in 2001 in Havana, Cuba, The World Forum on Food Sovereignty; and in 2007 in Mali, the Nyeleni Forum on Food Sovereignty. This latter event brought together 600 representatives from peasant communities, landless people, scholars, urban and rural grassroots organizations, consumers, and environmental and urban movements from more than 80 countries. Pimbert notes that "the broad range of farmers and other citizens involved in these ongoing discussions has decisively shaped the concept of food sovereignty over the last decade. The concept has thus been discussed, debated and defined under the leadership of La Via Campesina, but with the support and participation of a growing number of other organizations" (Pimbert 2009: 6-7).

Then, other two international conferences were organized - at Yale University in September 2013, and at the International Institute of Social Studies (ISS) in The Hague in January 2014 - where scholars and food sovereignty activists engaged in a critical dialogue. The character of such encounters - opening questions about the meanings, objectives, and possibilities of such radical changes, and attempting to elucidate how those changes could be triggered and sustained at multiple scales and contexts - reflects that food sovereignty is a highly contested concept and it is still in process of definition (Edelman 2014).

${ }^{15}$ The expansion of agribusiness sustaining this industrial complex has been identified as one of the central forces driving land and water grabs worldwide. Though there is not consensus regarding the methodology for measuring land and water grabs, estimations made by the Land Matrix Global Observatory, an international coalition of research institutes monitoring large-scale land acquisitions ( $<200$ hectares), calculates that almost 50 million hectares have been sold, leased or concessioned worldwide since the year 2000. According to the Observatory, most of these land transfers have taken place in the global South, and the United States is the main investor with the acquisition of almost 10 million hectares.

${ }^{16}$ van der Ploeg identifies six major dynamics defining the contemporary peasantry and its counter-proposal to the project of modernization and industrial agriculture, which he terms "dialectics of continuity and change that link peasant farming from earlier times to the current peasant configurations and which simultaneously differentiate the former from the latter" (2010:2): (1) land and ecological exchange; (2) autonomy and production for self-consumption; (3) actively constructed distantiation from markets; (4) dynamic co-production; (5) multiple resistance; and (6) extended networks.

${ }^{17}$ In 2009, a multidisciplinary study analyzing gene flow and the possible introduction of transgenes into native maize in the region of the Sierra Juarez, Oaxaca, Mexico, confirmed transgene presence in local native maize (Pineiro-Nelson 2009: 759). This research reinforces the growing concern that a possible consequence of planting 
genetically modified organism (GMOs) in centers of crop origin is unintended gene flow into traditional landraces (See also Dyer et al. 2009).

\section{Chapter Two}

${ }^{1}$ While scholars concur that the majority of communal lands were expropriated during those years, there is not agreement about the precise extent of those confiscations or the integration of indigenous labor into the finca economy (Katz 1974: 1). This is essentially a methodological disagreement about how to measure land concentration and the distribution of labor force in the fincas using the data presented in the national censuses of 1895 and 1910, which had only established two raw classifications for rural population: farmers and peones (see Meyer 1986: 491 for a critical discussion).

${ }^{2}$ According to Rus, between 1837 and 1889, three years before the Ejidos Law, the numbers of fincas in Chiapas grew from 853 to 3,159 (2003: 263).

${ }^{3}$ For instance, Guerra (1985: 479) and Meyer (1986: 500) estimate that the proportion of the national rural population living in the haciendas in 1910 did not exceed 30 percent. These numbers reinforce the work of Friedrich Katz (1974), who found that "permanent resident peons generally constituted a minority of the work force on most Mexican haciendas. The main work on haciendas was carried out by temporary workers" (1974: 5). Katz identifies four broad categories of workers in the fincas: (1) permanent resident peons or peones acasillados; (2) temporary workers who worked the terrateniente's fields for a limited time in the year; (3) tenants; and (4) sharecroppers (1974: 4).

${ }^{4}$ According to published data from Vice-President Corral, in 1908 the government had more than 50,000 soldiers "who were ready to take the field at an hour's notice" (in Turner 1910: 142). To these numbers, Turner added the rurale forces or paramilitary groups - 7,000 to 9,000 individuals - who were spread all over the country, "a mounted police usually selected from the criminal classes...whose energies have been turned to robbing and killing for the government" (1910: 178).

${ }^{5}$ Sanderson calculates that by 1970 more than 60 percent of Chiapas' agricultural land had been granted to ejidos (1984: 100)

${ }^{6}$ Sebastian, interview, San Cristóbal, February 2016.

${ }^{7}$ Sebastian and Elena, interviews, February 2016, San Cristóbal de las Casas.

${ }^{8}$ The 1971-1974 run-up in prices that had been triggered by a sudden increase in the global demand for grains and oilseeds was followed by a drop in commodities prices (Peters 2009, Arslan 2003). Indeed, since 1971 global agricultural commodity markets have become highly volatile and cyclical price-crises are recurrent (i.e., 1984, 1996, 2008) (Peters 2009). Throughout these years commodities' real prices (although not nominal prices) have systematically fallen (Arslan 2003). This is the case for most of Mexican agro-exports such as cocoa, coffee, sugar, rubber, cotton, maize, and wheat.

${ }^{9}$ The fiscal crisis of the late 1960s, reinforced in 1975 by the collapse of the agro-export sector, precluded Mexico from further developing its production of durable consumer goods, heavy intermediate goods, and capital goods industries. At the beginning of the 1970s, Mexican industrialization had stagnated at the first stage of non-durable consumer goods and light intermediates production (Ros 1993: 3, Cueva 1977: 184-200). 
${ }^{10}$ On October 2, during a pacifist protest in Mexico City, military and paramilitary groups assassinated almost 300 students and injured more than 1,000; the massacre was followed by a wave of political repression that lasted several years (Poniatowska 1971).

${ }^{11}$ Salinas's opponent was the leftist Cuauhtémoc Cárdenas, Lázaro Cárdenas's son, who overwhelmingly had won the popular vote. Following the election, Salinas de Gortari openly threatened using the military force to counteract any demostration denouncing the electoral fraud.

${ }^{12}$ The aims of the Agricultural Sector Adjustment Loan I were: "to strengthen policy reforms and to sustain an agricultural policy dialogue with the Government. Specific objectives were to: (a) remove global food subsidies and target remaining food subsidies to the poor; (b) reduce government intervention in agricultural markets, including movement from guaranteed prices for wheat, barley, rice, sorghum, soybean, sesame, sunflower, cottonseed and copra towards market-determined pricing; (c) abolish export controls and quantitative restrictions (QRs) on key products; (d) reduce the role of agriculture parastatals; (e) liberalize agricultural trade; (f) cut subsidies to inputs; (g) better the efficiency of public investment in agriculture and raise it in real terms; and (h) decentralize and cut staff of the agricultural ministry" (World Bank 1994: iii).

${ }^{13}$ The objectives of the Agricultural Sector Adjustment Loan II were to "support: (a) trade policy reforms that increase competition and reduce the government's role in the production, planning, marketing, storage and processing of agricultural products and inputs, and by allowing more competition from the private sector; (b) revision in the allocation of government expenditure in consumer programs by eliminating generalized food subsidies and increasing spending for improved targeted food assistance and nutritional programs; and (c) the institutional transition of SARH (Secretaría de Agricultura y Recursos Hidráulicos) to a smaller but more effective role in agriculture, emphasizing policy formulation and implementation and basic regulatory function" (World Bank 1991: i).

\section{Chapter Three}

${ }^{1}$ According to Nations and Night, during the colonial period the process of population of the Lacandon rainforest was marked by cycles of indigenous immigration into the rainforest - some of them fleeing disease and disruption in their original territoriesfollowed by their forced relocation by colonizers into Spanish-controlled villages on the jungle's western and southern fringes. The period of isolation of the few who managed to remain in the middle of the jungle - a group of Mayan Yucatec-speaking refugees from Guatemala, who inherited the name of the original Lacandones-"ended in the 1940s, when the Ley de Reforma Agraria was applied in northeastern Chiapas, and most of the tropical lowlands was reclassified as national territory. As such, the Lacandon jungle was opened to colonization." Stimulated by this policy, large numbers of Tseltal and Choles Maya returned to the ancestral home from which their ancestors had been removed in the sixteenth century. One decade later, in the 1950s, Tseltales and Tsotsiles from Los Altos arrived in the jungle in search of land (1980: 2-3). 
${ }^{2}$ According to Wolf, "the Crown encouraged the organization of the Indian population into compact communities with self-rule over their own affairs, subject to supervision and interference at the hands of royal officials. Many of the cultural forms of this community organization are pre-Hispanic in origin, but they were generally repatterned and charged with new functions. We must remember that the Indian sector of society underwent a serious reduction in social complexity during the $16^{\text {th }}$ and $17^{\text {th }}$ centuries. The Indians lost some of their best lands and water supply, as well as the larger part of their population. As a result of this social cataclysm, as well as of government policy, the repatterned Indian community emerged as something qualitative new: a corporate organization of a local group inhabited by peasants. Each community was granted a legal charter and communal lands; equipped with a communal treasury and administrative center; and connected with one of the newly-established churches. It was charged with the autonomous enforcement of social control, and with the payment of dues" (1956: 1067). This is the origin of contemporary indigenous communities. Together with ejidos, these two forms of collective landholding constitute the "social sector." Federal territory and private ownership are the other two forms of land tenure in the agrarian system in Mexico.

${ }^{3}$ Roberto and Luis, interviews, San Cristóbal. 2016.

${ }^{4}$ The word Caracol also connotes the conch shell the Mayans traditionally used to call a meeting. The spiral figure represents dialogue as well, a central concept of the Zapatista project (Klein 2015: 174).

5 The Women's Revolutionary Law, enacted in 1994, establishes ten rights: 1. Women, regardless of their race, creed, color or political affiliation, have the right to participate in the revolutionary struggle in any way that their desire and capacity determine; 2 . Women have the right to work and receive a just salary; 3 . Women have the right to decide the number of children they have and care for; 4 . Women have the right to participate in the matters of the community and to fill cargos if they are freely and democratically elected; 5. Women and their children have the right to primary attention in their health and nutrition; 6. Women have the right to education; 7 . Women have the right to choose their partner and are not obligated to enter into marriage; 8 . Women have the right to be free of violence from both relatives and strangers. Rape and attempted rape will be severely punished; 9. Women will be able to occupy positions of leadership in the organization and hold military ranks in the revolutionary armed forces; and 10. Women will have all the rights and obligations which the revolutionary laws and regulations provide.

${ }^{6}$ Javier, interview, Tenejapa, January 2017.

${ }^{7}$ Ibid.

${ }^{8}$ Ranges are determined by the relation between communities and conflict intensity, measured by the distance in $\mathrm{Km}$ between a community and a police or military position; what Zaga calls "areas of influence of the conflict," which go from 10 to $30 \mathrm{~km}$. ${ }^{9}$ Alberto, interview, September 2016.

${ }^{10}$ The San Andrés Accords proposed federal legislation granting civil rights and autonomy to indigenous peoples, which both the EZLN and the federal government signed in 1996 as part of the peace dialogue, but then the government refused to grant it the status of law. Despite mass support from civil society for the EZLN, the government 
refused to ratify the Accords, and on April 28, 2001, instead approved the Indigenous Law. It was a unilateral document that did not respond to the original Accords and the EZLN refused to accept it.

${ }^{11}$ Marcelino, interview, Cancuc, February 2016.

\section{Chapter Four}

${ }^{1}$ The Popol Vuh recounts the creation of the earth and humanity. It is a pre-conquest narrative dating to the Post-classic period, roughly between CE 1000-1500.

${ }^{2}$ Badstue et al. define seed system as "the set of sources of seed and related information, practices and transactional arrangements on which farmers rely to obtain seed for agricultural production" (2007: 1591)

${ }^{3}$ The Indian Theology is an autochthonous branch of the liberation theology or the "preference for the poor" doctrine, as it is called in Chiapas. It was born from the confluence between Catholicism and Mayan spirituality in the diocese of San Cristóbal at the beginning of the 1990s. This development was an indirect outcome of the institutionalization of an indigenous diaconate in 1973, promoted in the diocese by Bishop Samuel Ruiz, but it also reflects the growing importance of indigenous traditions, philosophies, and practices in a regional context marked by the Zapatista struggle for indigenous autonomy. Members of the Indian Theology are part of the Diocese of San Cristóbal; however, there are many practitioners of the Mayan theology who do not hold an official position in the Catholic Church. Some of them might have different cargos or spiritual positions in their own communities. There is also a growing group of indigenous intellectuals, as Jxun and Xaw, who contribute to the documentation, study, interpretation, and reproduction of traditional practices in indigenous communities. Jxun and Xaw, personal communication.

${ }^{4}$ The territorial area of the diocese of San Cristóbal coincides almost exactly with the region of conflict; see Figure 11 in Chapter 5.

${ }^{5}$ Xaw and Jxun, collective interview, February 2016.

${ }^{6}$ This description summarizes the information I gathered from different informants in different ceremonies.

7 Michele Gamburd definition, personal communication, May 2018, Portland, Oregon.

${ }^{8}$ Susana, interview, Teopisca, December 2015.

${ }^{9}$ Ramiro, interview, Venustiano Carranza, February 2016.

${ }^{10}$ Agustina, fieldnotes, Tumbalá, February 2016.

${ }^{11}$ José, interview, Cancuc, December 2015.

12 Juanita, fieldnotes, Tenejapa, December 2015.

${ }^{13}$ Lorenzo, fieldnotes, San Cristóbal, November 2015.

${ }^{14}$ Loxa, interview, Oventic, December 2015.

${ }^{15}$ Isabela, interview, San Andrés, October 2015.

${ }^{16}$ Hugo Perales, personal communication.

${ }^{17}$ Marcelo, fieldnotes, Cancuc, September 2015.

${ }^{18}$ Rosario, fieldnotes, Teopisca, January 2016. 
${ }^{19}$ Marcelo, fieldnotes, Cancuc, January 2016.

${ }^{20}$ Nations and Nigh write: "the agricultural and silvicultural techniques of the ancient Maya - techniques based on ridged fields, water control, intercropping schemes, and complex scheduling of activities - are for the most part lost to scientific inquiry. Much of this specialized knowledge perished in the massive depopulation which followed the Spanish conquest of the Maya area; only a few Maya groups continue to use elements of this practical environmental knowledge...The Spanish conquest destroyed the technical elite class that engineered such intensive food-production sites, but, even more importantly, depopulation caused by post-conquest war and disease removed the economic motive for such complex hydraulic control" (1980: 2, 26). The most comprehensive contemporary study analyzing demographic changes of indigenous peoples in America after the arrival of Cristobal Colón calculates that as a result of both slavery and epidemics, indigenous population decreased from 53.9 million people in 1492 to 5.6 million in 1650 - that is a decrease of 90 percent in the indigenous population (Denevan 1992: xxix).

${ }^{21}$ Hugo Perales, personal communication, 2017.

${ }^{22}$ Manuel, interview, San Cristóbal, January 2016.

${ }^{23}$ Hugo Perales, interview, San Cristóbal, February 2016.

${ }^{24}$ Alux, interview, Tenejapa, February 2016.

${ }^{25}$ Don Antonio, interview, Teopisca, December 2015.

${ }^{26}$ Fieldnotes.

${ }^{27}$ Hugo Perales, interview, San Cristóbal, February 2016.

${ }^{28}$ Petul, interview, San Cristóbal, February 2016.

${ }^{29}$ Marcela, interview, February 2016.

${ }^{30}$ Manuel, fieldnotes, September, 2015.

${ }^{31}$ Hugo Perales, interview, San Cristóbal, February 2016.

${ }^{32}$ Mariano, interview, San Cristóbal, October 2015.

${ }^{33}$ Jxun, interview, Cancuc, October 2015.

${ }^{34}$ In their study analyzing the adoption rate of HYVs and its impact on GDP per capita among 84 developing countries, Gollin et al. found that the average country had an HYV adoption rate of 27 percent in 2000. This has translated into a 50 percentage point contribution to growth in GDP per capita during the period 1960-2000. Considering that the HYV adoption rate is positively correlated with country size and level of industrialization, there is a huge variation in adoption among countries. On the one extreme, there are countries such as India and Brazil with adoption rates of 75 and 55 percent respectively; on the other, some African countries such as Nigeria have an adoption rate of only 20 percent. However, when the developing world is considered as a whole - all 84 countries taken together - the HYV adoption rate increases to 58 percent, which implies a 139 percentage point GDP growth contribution. "The numbers strongly suggest that the Green Revolution has been a very important source of economic growth in developing countries," write Gollin et al. "Our results show that about 60 percent of the effect on income per capita can be attributed to productivity increases in agriculture, whereas the remaining 40 percent comes from the movement of workers out of agriculture and into more productive occupations" (2016: 30-31). 
${ }^{35}$ Quist and Chapela's controversial results were later corroborated by a multidisciplinary research coordinated by the Universidad Autónoma de México (UNAM) published in 2009 (Piñeyro-Nelson 2009).

${ }^{36}$ According to De Schutter, the Special Rapporteur on the Right to Food from the United Nations, "the right to food is the right to have regular, permanent and unrestricted access, either directly or by means of financial purchases, to quantitatively and qualitatively adequate and sufficient food corresponding to the cultural traditions of the people to which the consumer belongs, and which ensure a physical and mental, individual and collective, fulfilling and dignified life free of fear" (UN 2017).

${ }^{37}$ This court decision took place after Monsanto presented two applications (still pending) for the commercial planting of GM corn on 700,000 hectares (1.7 million acres) in the northwestern state of Sinaloa, now the country's largest corn-producing area. Due to the mass citizen mobilizations against Monsanto and GM corn, the government decided to deny the permits. Then, in 2015, a court decision reaffirmed the moratorium and ordered Sagarpa to "suspend all activities involving the planting of transgenic corn in the country and end the granting of permission for experimental and pilot commercial plantings." This success, however, was only partial. After 93 appeals by the biotech industry, a new court decision allowed the experimentation and implementation of pilot programs if they met all safety measures for preventing contamination (Enciso 2015, Lesperance 2017).

${ }^{38}$ In 2012, the Sagarpa, under the leadership of Jorge Kondo, authorized the commercial planting of Monsanto's GM RR Soybean on 253,500 hectares in seven states of Mexico: Campeche, Quintana Roo, Yucatán, Chiapas, San Luis Potosi, Tamaulipas, y Veracruz (La Jornada del Campo 2015).

${ }^{39}$ Mariano, interview, San Cristóbal, October 2015.

${ }^{40}$ Hugo Perales, interview, San Cristóbal, February 2016.

${ }^{41}$ Eakin et al. define households as 'maize sellers' if they were producing more than needed to meet subsistence requirements. They establish a per capita consumption estimate of $200 \mathrm{~kg} /$ year per child under twelve and $274 \mathrm{~kg} / \mathrm{year}$ per adult, and calculate the total consumption requirements for each household. Households that produced equal to, or less than, 1.25 times expected consumption were classified as 'non-sellers' of maize and households that produced more than 1.25 their expected consumption were classified as 'sellers' (2014: 139-140).

${ }^{42}$ José, interview, Tenejapa, February 2016.

${ }^{43}$ Fieldnotes, San Andrés, October 2015.

${ }^{44}$ Marcelino, interview, Cancuc, February 2016.

${ }^{45}$ Sebastian, interview, San Cristóbal, February 2016.

${ }^{46}$ Jimena, interview, Venustiano Carranza, February 2016.

${ }^{47}$ Juanita, interview, Teopisca, February 2016.

${ }^{48}$ Fieldnotes.

${ }^{49}$ Prospera offers up to two scholarships per household from primary to high school, and the amount of money is slightly higher for female students.

${ }^{50}$ Jtin, interview, Tenejapa, January 2016.

${ }^{51}$ Rosa, interview, Tumbalá, February 2016. 
${ }^{52}$ Josefa, interview, Teopisca, December 2015.

${ }^{53}$ Ana, interview, Tumbalá, February 2016.

${ }^{54}$ Javier, fieldnotes, San Andrés, October 2015.

${ }^{55}$ Marcela, interview, San Cristóbal, December 2015.

${ }^{56}$ Salvador, fieldnotes, San Andrés, October 2015.

${ }^{57}$ Agustino, interview, Cancuc, January 2016.

${ }^{58}$ Julian, fieldnotes, San Andrés, October 2015.

${ }^{59}$ Ruben, interview, Cancuc, February 2016.

${ }^{60}$ Marta, interview, Venustiano Carranza, February 2016.

${ }^{61}$ Maricela and Esmeralda, interview, Venustiano Carranza, February 2016.

${ }^{62}$ Emanuel Gómez, Interviw, San Cristóbal, February 2016.

${ }^{63}$ Jaime, interview, Venustiano Carranza, February 2016.

${ }^{64}$ Recording, October 2015.

${ }^{65}$ Recording, October 2015.

${ }^{66}$ Margarita, interview, San Andrés, October 2015.

\section{Chapter Five}

${ }^{1}$ Luis, interview, San Cristóbal, February 2016.

${ }^{2}$ Sebastian, interview, San Cristóbal, March 2016.

${ }^{3}$ Mariano, interview, San Cristóbal, November 2015.

${ }^{4}$ Ibid.

${ }^{5}$ Interestingly, it was the first bishop of the Diocese of San Cristóbal, the Spanish Dominican friar Bartolomé de las Casas (1484-1566), who was appointed as the "Protector of the Indians" by the Spanish crown. His advocacy for indigenous rights was a determinant factor influencing the writing of the papal bull Sublimis Deus of 1537, which recognized the status of the Indians as rational beings. Then, in 1542 Bartolomé de las Casas wrote $A$ Short Account of the Destruction of the Indies, one of the most important chronicles of the first decades of colonization of America. It narrates the atrocities - torture, murder, mutilation — committed by the colonizers against indigenous peoples. Bartolomé de las Casas sent it to Carlos V, King of Spain and Holy Roman Emperor, and requested the implementation of laws abolishing slavery and protecting the lives of natives. In response, the crown enacted that same year the New Laws of the Indies for the Good Treatment and Preservation of the Indians. The laws abolished slavery and established the provisions for the gradual dismantling of the encomienda, a labor system instituted in 1503 granting conquerors rights to a specified amount of Indian tribute and labor, held in perpetuity by the encomendero and his descendants. However, these laws they were never fully implemented (Dumont 2009: 183-263, Wild 1998). The encomienda lasted until 1720 (Zamorano 2001: 39). If not in law, slavery of indigenous people remained the soul of the encomienda. It was only after Samuel Ruiz started to advocate for the institutionalization of an indigenous deaconate when the Catholic Church incorporated it as part of its canon. However, after Samuel Ruiz's death, the Vaticano reverted this decision. 
${ }^{6}$ 1989: Human Rights Center Fray Bartolome de las Casas (FRAYBA); 1994: the international coalition of civil organizations SIPAZ (International Service for Peace); 1996: Commission for the Support to Communal Unity and Reconciliation (CORECO) and the Bible School of Holistic Formation (which becomes the Institute of Intercultural Studies and Research, INESIN, in 2002); 1998: Services and Advices for Peace (SERAPAZ) in Mexico City.

${ }^{7}$ Sebastian, interview, San Cristóbal, February 2016.

${ }^{8}$ Interviews and personal communication with DESMI staff; 2015-2016.

${ }^{9}$ For instance, in 1974 The Quiptic Ta Lecubtesel, and the ejidal unions Tierra y Libertad and Lucha Campesina were created in the Lacandona region. Between 1976-1980, in the northern region, a peasant alliance of 37 ejidos occupied 19 fincas. In 1979, the Coordinadora Nacional Plan de Ayala (CNPA) was created in Mexico City and the diocese helps to expand its influence in Chiapas; in 1980, Tierra y Libertad and Lucha Campesina created the Unión de Uniones Ejidales y Grupos Campesinos Solidarios de Chiapas, which integrates 150 communities from 11 municipalities. In 1980, the Coordinadora Provisional de Chiapas (CPCH), the local version of the CNPA, was created in Venustiano Carranza; and in 1982, the Organizacion Campesina Emiliano Zapata (OCEZ) was created from a fusion of $\mathrm{CPCH}$ and ejidos from the municipalities of Simojovel and Las Margaritas.

${ }^{10}$ Interviews and personal communication with DESMI staff; 2015-2016.

${ }^{11}$ Sebastian and Elena, personal communication.

${ }^{12}$ Maricela, interview, San Cristóbal, January 2016.

${ }_{13}^{13}$ Mateo, interview, San Cristóbal, February 2016.

${ }^{14}$ Personal communication with DESMI staff.

${ }^{15}$ Sebastian, personal communication.

${ }^{16}$ Julia, interview, San Cristóbal, February 2016.

${ }^{17}$ Elena, interview, San Cristóbal, February 2016.

${ }^{18}$ Ibid.

${ }^{19}$ Sebastian, interview, San Cristóbal, March 2016.

${ }^{20}$ Elena, interview, San Cristóbal, February 2016.

${ }^{21}$ Sebastian, interview, San Cristóbal, March 2016.

${ }^{22}$ Ibid.

${ }^{23}$ Ibid.

${ }^{24}$ Ibid.

${ }^{25}$ INESIN coordinates the agenda of Spirituality and Ecology; CORECO, SERAPAZ, SIPAZ, and UCCS are responsible for Context Analysis; FRAYBA coordinates Legal and Organizational Support; and DESMI coordinates Food Sovereignty and Agroecology (GAP 2015).

${ }^{26}$ Mariano, personal communication, December 2015.

${ }^{27}$ Several people I interviewed from the Pastoral, INESIN, and DESMI referred to these meetings; and some of them took place during my fieldwork.

${ }^{28}$ Pedro, interview, San Cristóbal, February 2016.

${ }^{29}$ Luis, interview, San Cristóbal, February 2016. 
${ }^{30}$ Land and territory, land and family, land and migration, land and food sovereignty, land and strategic natural resources, land and youths, land and women, and land, alternative education, and health.

\section{Chapter Six}

${ }^{1}$ Fieldnotes from Tumbalá, November 7-10, 2016.

${ }^{2}$ Fieldnotes from Teopisca (group 4), October 15, 2016.

${ }^{3}$ Fieldnotes from Teopisca (group 4), October 15, 2016.

${ }^{4}$ Fieldnotes from Teopisca (group 5), September 3, 2016.

${ }^{5}$ Fieldnotes from Cancuc, September 9, 2016.

${ }^{6}$ Fieldnotes from Tumbalá, November 7-10, 2016.

${ }^{7}$ Jtin, interview, Tenejapa, January 2016.

${ }^{8}$ Hugo Perales, personal communication.

${ }^{9}$ Elena, personal communication, January 2016.

${ }^{10}$ Mariano, interview, October 2016.

${ }^{11}$ Felipe, interview, Teopisca, February 2016.

${ }^{12}$ Adolfo, interview, Venustiano Carranza, February 2016.

${ }^{13}$ Mariano, personal communication, December 2015.

\section{Conclusions}

${ }^{1}$ Hugo Perales, personal communication.

2 Emanuel Gómez, interview, February 2017, San Cristóbal de las Casas.

${ }^{3}$ Ibid.

${ }^{4}$ Ibid.

\section{Appendix: Research Methods}

${ }^{1}$ Such negative perceptions have become stronger after several "biopiracy scandals" in the region in the last two decades. Particularly controversial was the Maya International Cooperative Biodiversity Group (Maya ICBG) bioprospecting project for Los Altos of Chiapas (a joint research between the University of Georgia in the U.S. and Ecosur in Chiapas), which began in 1999 and concluded few years latter with an open confrontation between communities and the research centers involved in the project (see ETC Group 1999, Berlin 1999, Night 2002). 


\section{REFERENCES}

Alire Garcia, David. 2017. "Monsanto Sees Prolonged Delay on GMO Corn Permits in Mexico." Reuters, January 30. Retrieved October 11, 2017

(https://www.reuters.com/article/us-mexico-monsanto/monsanto-sees-prolongeddelay-on-gmo-corn-permits-in-mexico-idUSKBN15E1DJ).

Altieri, Miguel, and Clara Nicholls. 2008. "Scaling up Agroecological Approaches for Food Sovereignty in Latin America." Development 51(4):472-480.

Appendini, Kirsten. 2001. "Land Regularization and Conflict Resolution: The Case of Mexico." Report for FAO (Food and Agriculture Organization of the United Nations), Rural Development Division.

Appendini, Kirsten. 2014. "Reconstructing the Maize Market in Rural Mexico." Journal of Agrarian Change 14(1):1-25. Doi: 10.1111/joac.12013.

Araghi, Farshad. 2010. "Food Regimes and the Production of Value: Some Methodological Issues." The Journal of Peasant Studies 30(2):41-70.

Aragón, J. M. 2012. Zapatistas Silent Mobilization. Pan Left Productions. YouTube Website. Retrieved October 16, 2017 (https://www.youtube.com/watch?v=5K_z_ceSlwE).

Arslan Gurkan, Ali. 2003. "Commodity Price Development Since the 1970s." Report for FAO (Food and Agriculture Organization of the United Nations), Commodities and Trade Division. Retrieved October 15, 2017 (http://www.fao.org/docrep/006/Y4344E/y4344e0g.htm\#TopOfPage).

Aubry, Andrés. 2004. "El Congreso Indígena de 1974, 30 Años Después," La Jornada, October 15. Retrieved November 17, 2017

(http://www.jornada.unam.mx/2004/10/15/012a1pol.php?origen=opinion.php\&fly $=1)$.

Aubry, Andrés, and Inda Angélica. 1998. "Who Are the Paramilitaries in Chiapas?" NACLA Report on the Americas 31(5):8-9.

Badstue, Lone, Mauricio Bellon, Julien Berthaud, Alejandro Ramírez, and Xóchitl Juárez. 2007. "The Dynamics of Farmers' Maize Seed Supply Practices in the Central Valleys of Oaxaca, Mexico." World Development 35(9):1579-1593.

Badstue, Lone, Mauricio Bellon, Julien Berthaud, Xóchitl Juárez, Irma Manuel Rosas, Ana Maria Solano, and Alejandro Ramírez. 2006. "Examining the Role of Collective Action in an Informal Seed System: A Case Study from the Central Valleys of Oaxaca, Mexico." Human Ecology 34(2):249-273.

Baines, Joseph. 2015. "Fuel, Feed and the Corporate Restructuring of the Food Regime." Journal of Peasant Studies 42(2):295-321.

Baker, Lauren. 2013. Corn Meets Maize: Food Movements and Markets in Mexico. Lanham, MD: Rowman \& Littlefield.

Bakker, Karen. 2005. "Neoliberalizing Nature? Market Environmentalism in Water Supply in England and Wales." Annals of the Association of American Geographers 95(3):542-565.

Barbosa, Fabio, and Nicolás Domínguez. 2006. "Situación de las Reservas y el Potencial Petrolero de México." Economía UNAM 3(7):79-102. 
Barkin, David. 1987. "The End to Food Self-sufficiency in Mexico." Latin American Perspectives 14(3):271-297.

Barmeyer, Niels. 2009. Developing Zapatista Autonomy. Albuquerque, NM: University of New Mexico Press.

Baronnet, Bruno. 2009. "Autonomía y Educación Indígena: las Escuelas Zapatistas de Las Cañadas de la Selva Lacandona de Chiapas, México." Tesis Doctoral, Departamento de Sociología, Colegio de México, Ciudad de México, México.

Baronnet, Bruno, Mariana Mora Bayo, and Richard Stahler-Sholk. 2011. Luchas Muy Otras: Zapatismo y Autonomía en las Comunidades Indígenas de Chiapas. Ciudad de México, México: CIESAS, UAM-Xochimilco, UNACH.

Barry, Tom. 1995. Zapata's Revenge: Free Trade and the Farm Crisis in Mexico. Boston: South End Press.

Baumann, Friederike. 1983. "Terratenientes, Campesinos y la Expansión de la Agricultura Capitalista en Chiapas, 1986-1916." Mesoamérica 4(5):8-63.

Bautista, Marvin. 2016. "Chiapas Sí Podrá Cultivar Soya Transgénico, Aclara la SCJN," Diario de Facto, Marzo 12. Retrieved November 23, 2017 (http://defacto.mx/municipios/chiapas-podra-cultivar-soya-transgenico-aclara-lascjn/).

Bautista, Marvin. 2017. "Adiós a la Semilla Transgénica en Chiapas: Productores de Soya," Reporte Ciudadano Chiapas, Mayo 29. Retrieved October 16, 2017 (http://www.reporteciudadanochiapas.com/?p=146273).

Bell, Michael, and Philip Lowe. 2000. "Regulated Freedoms: The Market and the State, Agriculture and the Environment." Journal of Rural Studies 16:285-294.

Bellingeri, Marco, and Isabel Gil Sánchez. 1980. "Las Estructuras Agrarias Bajo el Porfiriato." Pp. 315-337 in México en el Siglo XIX, 1821-1910: Historia Económica de la Estructura Social, edited by Ciro Cardoso, Flamarion Santana, and José Antonio Bátiz Vázquez. Ciudad de México, México: Patria.

Bellinghausen, Hermann. 2012. "Se Movilizan Más De 40 Mil Zapatistas En 5 Municipios De Chiapas." La Jornada, Deciembre 22. Retrieved: May 28 (http://www.jornada.unam.mx/2012/12/22/politica/002n1pol).

Bello, Walden. 2009. The Food Wars. Brooklyn: Verso.

Bellon, Mauricio, David Hodson, and Jon Hellin. 2011. "Assessing the Vulnerability of Traditional Maize Seed Systems in Mexico to Climate Change." PNAS 108(33):13432-13437. doi: 10.1073/pnas.1103373108.

Benbrook, Charles. 2016. "Trends in Glyphosate Herbicide Use in the United States and Globally." Environmental Sciences Europe 28(3):1-15.

Benjamin, Thomas. 1990. El Camino a Leviatán: Chiapas y el Estado Mexicano, 18911947. Ciudad de México, México: Consejo Nacional para la Cultura.

Benz, Bruce, Hugo Perales, and Stephen Brush. 2007. "Tzeltal and Tzotzil Farmer Knowledge and Maize Diversity in Chiapas, Mexico." Current Anthropology 48(2):289-300.

Berlin, Brent, Elois Ann Berlin, José Carlos Fernández Ugalde, Luís García Barrios, David Puett, Robert Nash, and Mario González-Espinoza. 1999. "The Maya ICBG: Drug Discovery, Medical Ethnobiology, and Alternative Forms of 
Economic Development in the Highland Maya Region of Chiapas, Mexico." Pharmaceutical Biology 37(4):127-144.

Bernstein, Henry. 2014. "Food Sovereignty Via the 'Peasant Way': A Sceptical View." Journal of Peasant Studies 41(6):1031-1063.

Bernstein, Henry. 2016. "Agrarian Political Economy and Modern World Capitalism: The Contributions of Food Regime Analysis." The Journal of Peasant Studies 43(3):611-647. doi: 10.1080/03066150.2015.1101456.

Bonny, Sylvie. 2017. "Corporate Concentration and Technological Change in the Global Seed Industry." Sustainability 9(9):1-25. doi: 10.3390/su9091632.

Booth, John, Christine Wade, and Thomas Walker. 2014. Understanding Central America: Global Forces, Rebellion, and Change. Boulder, CO: Westview Press.

Borras, Jr. Saturnino, Philip McMichael, and Ian Scoones. 2010. "The Politics of Biofuels, Land and Agrarian Change: Editors' Introduction." Journal of Peasant Studies 37(4):575-592.

Bourne, Joel, and Robert Clark. 2007. "Green Dreams. Making Fuel from Crops Could Be Good for the Planet, After a Breakthrough or Two." National Geographic October:38-59.

Brandt, Marisa. 2014. "Zapatista Corn: A Case Study in Biocultural Innovation." Social Studies of Science 44(6):874-900.

Bray, Chad. 2017. "Bayer-Monsanto Deal Faces Deeper Scrutiny in Europe," New York Times, August 22. Retrieved December 9, 2017

(https://www.nytimes.com/2017/08/22/business/dealbook/bayer-monsantoeu.html?emc $=$ eta1\&_r=0).

Brown, Peter. 2013. "Maya Mother Seeds in Resistance of Highland Chiapas in Defense of Native Corn." Pp. 151-76 in Seeds of Resistance, Seeds of Hope: Place and Agency in the Conservation of Biodiversity, edited by Virginia Nazarea, Robert Rhoades, and Jenna Andrews-Swann. Tucson, AZ: The University of Arizona Press.

Brush, Stephen, and Hugo Perales. 2007. "A Maize Landscape: Ethnicity and AgroBiodiversity in Chiapas Mexico." Agriculture, Ecosystems \& Environment 121(3):211-221. doi: 10.1016/j.agee.2006.12.018.

Brush, Stephen. 2005. Farmers' Rights and Protection of Traditional Agricultural Knowledge. Washington, D.C.: International Food Policy Research Institute.

BSPB, The British Society of Plant Breeders. 2013. "FAQs on Farm-Saved Seed". Retrieved April 3, 2018 (http://www.bspb.co.uk/sg_userfiles/FarmSaved_Seed_FAQs_FINAL_Aut13.pdf).

Buckler, Edward, and Natalie Stevens. 2005. "Maize Origins, Domestication, and Selection." Pp. 67-90 in Darwin's Harvest, edited by Timothy. Motley, Nyree Zerega, and Hugh Cross. New York: Columbia University Press.

Busch, Christopher, and Jaqueline Geohegan. 2010. "Labor Scarcity as an Underlying Cause of the Increasing Prevalence of Deforestation Due to Cattle Pasture Development in the Southern Yucatan Region." Regional Environment Change 10(3):191-203. 
Callahan, Patricia, and Scott Kilman. 2001. "Seeds of Doubt: Some Ingredients Are Genetically Modified, Despite Label Claims," Wall Street Journal, April 5.

Camou Guerrero, Teresa. 2015. Sunú. Sunú Website. Retrived October 12, 2017 (http://sunudoc.com/en/homepage/).

Campell, Richmond. 1985. "Background for the Uninitiated." Pp. 3-41 in Paradoxes of Rationality and Cooperation, edited by Richmond Campell, and Lanning Sowden. Vancouver: University of British Columbia Press.

Castellanos, Laura. 2014. "Gobierna el EZLN a 250 mil Indígenas," El Universal, January 2. Retrieved September 18, 2017

(http://chacatorex.blogspot.com/2014/01/gobierna-el-ezln-250-milindigenas.html).

Castellanos, Rosario. 1957. Balún-Canán. Ciudad de México, México: Fondo de Cultura Económica.

CBSNews. 2016. "100,000 Dead, 30,000 Missing: Mexico’s War on Drugs Turns 10." Retrieved February 4, 2018 (https://www.cbsnews.com/news/100000-dead30000-missing-mexico-war-on-drugs-turns-10/).

CECCAM, Centro de Estudios para el Cambio en el Campo Mexicano. 2009. Las Semillas del Hambre: Ilegalizar la Memoria Campesina. Ciudad de México: CECCAM.

Cedillo, Adela. 2010. "El Suspiro del Silencio. De la Reconstrucción de las Fuerzas de Liberación Nacional a la Fundación del Ejército Zapatista de Liberación Nacional (1974-1983)." Tesis de Maestría, Departamento de Historia, Facultad de Filosofía y Letras, UNAM, México.

Cedillo, Adela 2008. "El Fuego y el Silencio: Historia de las Fuerzas de Liberación Nacional Mexicanas (1969-1974)." Tesis de Licenciatura, Departamento de Historia, Facultad de Filosofía y Letras, UNAM, México.

CEDOZ, Centro de Documentación sobre Zapatismo. 2018a. "Listado de Caracoles, Juntas de Buen Gobierno y Municipios Autónomos Zapatistas." Retrieved April 2, 2018 (http://www.cedoz.org/site/content.php?doc=481\&cat=82).

CEDOZ, Centro de Documentación sobre Zapatismo. 2018b. "Mapas." Retrieved April 2, 2018 (http://cedoz.org/site/content.php?cat=20).

CH, Catholic Hierarchy. 2017. "Diocese of San Cristóbal De Las Casas." Retrieved November 10, 2017 (http://www.catholic-hierarchy.org/diocese/dsncr.html).

Chao, Manu. 2017. Seeds of Freedom. Youtube Website. Retrieved March 21, 2018 (https://www.youtube.com/watch?v=-7LPVdBy_1o).

Chiapas, Gobierno. 2016. Estadística de Población. Retrieved July 16, 2017 (http://www.haciendachiapas.gob.mx/marcojuridico/Estatal/informacion/Lineamientos/Normativos/2016/XXII-EstadisticaPoblacion.pdf).

Chomsky, Noam. 2013. Occupy: Reflections on Class War, Rebellion, and Solidarity. Westfield, NJ: Zuccotti Park Press.

CIEPAC, Centro de Investigaciones Económicas y Políticas de Acción Comunitaria. 2018. "Grupos Paramilitares en Chiapas." Retrieved January 30, 2018 
(http://autonomiaautogestion.unach.mx/index.php?option $=$ com_content\&task $=$ vie w\&id=99\&Itemid=156).

CNI, Congreso Nacional Indígena. 2017. "La Asamblea del CNI Nombra Vocera del Concejo Indígena de Gobierno." Retrieved: May 28, 2017 (https:/www.congresonacionalindigena.org/2017/05/28/la-asamblea-del-cninombra-vocera-del-concejo-indigena-de-gobierno/).

CNI, Congreso Nacional Indígena. 1996. "Nunca Más un México sin Nosotros." YouTube Website. Retrieved September 28, 2017 (https://www.youtube.com/watch?v=t4vbvo3b-_Q).

COFEPRIS, Secretaria de Salud. 2015. "Lista de Evaluación de Inocuidad Caso por Caso de los Organismos Genéticamente Modificados (OGMs)". Retrieved October 27, 2017 (http://www.cofepris.gob.mx/AZ/Documents/OGMs/ogm.pdf).

Confino, Jo. 2012, "Vandana Shiva: Corporate Monopoly of Seeds Must End," The Guardian, October 2. Retrieved March 17, 2018

(https://www.theguardian.com/sustainable-business/vandana-shiva-corporatemonopoly-seeds).

Coomes, Oliver, Shawn McGuire, Eric Garine, Sophie Caillon, Doyle McKey, Elise Demeulenaere, Devra Jarvis, Guntra Aistara, Adeline Barnaud, Pascal Clouvel, Laure Emperaire, Selim Louafi, Pierre Martin, Francois Massol, Marco Pautasso, Chloe Violon, and Jean Wencelius. 2015. "Farmer Seed Networks Make a Limited Contribution to Agriculture? Four Common Misconceptions." Food Policy 56:41-50.

Córdova, Arnaldo. 1977. "México: Revolución Burguesa y Política de Masas." Cuadernos Políticos 13(Julio-Septiembre):85-101.

Cortés, Alberto. 2009. Corazón Del Tiempo. YouTube Website. Retrieved June 22, 2017 (https://www.youtube.com/watch?v=Vfz6gNb81PU).

Cueva, Agustín. 1977. El Desarrollo del Capitalismo en América Latina. Ciudad de México, México: Siglo XXI.

Cuevas, J. H. 2007. “Health and Autonomy: The Case of Chiapas." Report for WHO (World Health Organization), Health Systems Knowledge Network Commission. Rome. Retrieved January 21, 2018 (http://www.who.int/social_determinants/resources/csdh_media/autonomy_mexic o_2007_en.pdf).

Dalton, Timothy .J., C. Leigh Anderson, Leslie Lipper, and Alder Keleman. 2010. "Markets and Access to Crop Genetic Resources." Pp. 15-30 in Seed Trade in Rural Markets: Implications for Crop Diversity and Agricultural Development, edited by Leslie Lipper, C. Leigh Anderson, and Timothy J. Dalton. London: FAO and Earthscan.

de Ita, Ana. 2009 "Semillas Campesinas entre el Estado y las Transnacionales." Pp. 29-48 in Las Semillas Del Hambre: Illegalizar La Memoria Campesina, edited by CECCAM, Ciudad de México, México.

de Ita, Ana. 2006. "Land Concentration in Mexico after Procede." Pp. 148-164 in Promised Land. Competing Visions of Agrarian Reform, edited by Peter Rosset, Raj Patel, and Michael Courville. Oakland, CA: Food First Books. 
de Janvry, Alain. 1981. The Agrarian Question and Reformism in Latin America. Baltimore: Johns Hopkins University Press.

de Janvry, Alain, Elisabeth Sadoulet, and Gustavo Gordillo. 1995. "Nafta and Mexico's Maize Producers." World Development 23(8):1349-1362.

de Janvry, Alain, Kyle Emerick, Marco Gonzalez-Navarro, and Elisabeth Sadoulet. 2015. "Delinking Land Rights from Land Use: Certification and Migration in Mexico." American Economic Association 105(10):3125-3149.

de la Peña, Sergio. 1979. La Formación del Capitalismo en México. Ciudad de México, México: Siglo XXI Editores-UNAM.

De Schutter, Olivier 2009. "Seed Policies and the Right to Food: Enhancing Agrobiodiversity, Encouraging Innovation." Report for the United Nations General Assambly. Rome: FAO.

de Vos, Jan. 2002. Una Tierra para Sembrar Sueños. Historia Reciente de la Selva Lacandona, 1950-2000. Ciudad de México, México: Fondo de Cultura Económica.

de Vos, Jan. 1995. "El Lacandón: Una Introducción Historica." Pp. 331-61 in Chiapas: Los Rumbos de Otra Historia, edited by Juan Viqueira and Mario Humberto Ruz. Ciudad de México, México: UNAM.

de Vos, Jan. 1988. Oro Verde. La Conquista de la Selva Lacandona por los Madederos Tabasqueños, 1822-1949. Ciudad de México, México: Fondo de Cultura Económica.

Denevan, William. 1992. The Native Population of the Americas in 1492. Madison, WI: The University of Wisconsin Press.

Desmarais, Annette Aurelie. 2015. "The Gift of Food Sovereignty." Canadian Food Studies 2(2):154-163.

DESMI, Desarrollo Económico y Social de los Mexicanos Indígenas. 2017. "Economía Solidaria." Retrieved November 11, 2017 (http://www.desmi.org/economia.html).

DESMI. 2009. "La Agricultura Sostenible y la Soberanía Alimentaria para la Autonomía y la Autogestión Comunitaria." Pp. 139-175 in Agricultura Sostenible Campesino-indígena, Soberanía Alimentaria y Equidad de Género, edited by Eckart Boege, and Tzinnia Carranza. Ciudad de México, México: Pidaassa, Pan para el Mundo, and Xilotl.

DESMI. 2001. Si Uno Come, Que Coman Todos. Ciudad de México, México: DESMI and Oxfam.

Diemont, Stewart, Jay Martin, Samuel Levy-Tacher, Ronald Nigh, Pedro Ramírez López, and Duncan Golicher. 2005. "Lacandon Maya Forest Management: Restoration of Soil Fertility Using Native Tree Species." Ecological Engineering 28(3):205-12.

Diócesis, de San Cristóbal de las Casas. 2014. "Congreso de la Madre Tierra:

Comunicado Final." Retrieved November 11, 2017

(http://oclacc.org/redes/teologia/2014/02/congreso-de-la-madre-tierracomunicado-final/).

Diócesis, de San Cristóbal de las Casas. 2013. "Directorio Diocesano." Retrieved November 18, 2017 (http://diocesisdesancristob.wixsite.com/nada/services). 
Dumont, Jean. 2009. El Amanecer de los Derechos del Hombre: La Controversia de Valladolid. Madrid, España: Encuentro.

Dyer, George, Alejandro López-Feldman, Antonio Yúnez-Naude, and Edward Taylor. 2014. "Genetic Erosion in Maize's Center of Origin." PNAS 111(39):1409414099. doi: 10.1073/pnas.1407033111.

Dyer, George, and Antonio Yúnez-Naude. 2003. Nafta and Conservation of Maize Diversity in Mexico. Report for the Commission for Environmental Cooperation. Montreal: NAFTA.

Dyer, George, and Edward Taylor. 2008. "A Crop Population Perspective on Maize Seed Systems in Mexico." PNAS 105(2):470-475.

Dyer, George, Antonio Serratos-Hernández, Hugo Perales, Paul Gepts, Alma PiñeyroNelson, Angeles Chávez, Noé Salinas-Arreortua, Antonio Yuñez-Naude, Edward Taylor, and Elena Álvarez- Buylla. 2009. "Dispersal of Transgenes through Maize Seed Systems in Mexico." Plos One 4(5). doi: 10.1371/journal.pone.0005734.

Eakin, Hallie, Hugo Perales, Kirsten Appendini, and Stuart Sweeney. 2014a. "Selling Maize in Mexico: The Persistence of Peasant Farming in an Era of Global Markets." Development and Change 45(1):133-155.

Eakin, Hallie, Julia C. Bausch, and Stuart Sweeney. 2014b. "Agrarian Winners of Neoliberal Reform: The 'Maize Boom' of Sinaloa, Mexico." Journal of Agrarian Change 14(1):26-51.

Eakin, Hallie, Kirsten Appendini, Stuart Sweeney, and Hugo Perales. 2015. "Correlates of Maize Land and Livelihood Change among Maize Farming Households in Mexico." World Development 70:78-91. doi: 10.1016/j.worlddev.2014.12.012.

Edelman, Marc, Tony Weis, Amita Baviskar, Saturnino Borras Jr., Eric Holt-Giménez Deniz Kandiyoti, and Wendy Wolford. 2014. "Introduction: Critical Perspectives on Food Sovereignty." The Journal of Peasant Studies 41(6):911-931. doi: 10.1080/03066150.2014.963568.

Ehrenfeld, David. 1972. Conserving Life in Earth. New York: Oxford University Press. Enciso, Angélica. 2015. "Tribunal Ordena al Gobierno Federal Suspender Permisos a Transgénicos," La Jornada, November 4. Retrieved October, 17, 2017 (http://www.jornada.unam.mx/2015/11/04/sociedad/038n1soc).

Escobar, Arturo, and Sonia Álvarez (edit.). 2018. The Making of Social Movements in Latin America. Identity, Strategy, and Democracy. NY: Routledge.

Esping-Andersen, Gosta. 1990. The Three Worlds of Welfare Capitalism. Cambridge, U.K.: Polity.

ETC Group. 1999. "Organizaciones Indigenas Denuncian Biopirateria en Chiapas," December 1. Retrieved January, 10, 2018 (http://www.etcgroup.org/es/content/organizaciones-indigenas-denuncianbiopirateria-en-chiapas).

Evenson, R.E., and D. Gollin. 2003. "Assessing the Impact of the Green Revolution, 1960 to 2000." Science 300:758-762.

EZLN, Ejercito Zapatista de Liberación Nacional. 2016a. "Y Mientras Tanto...Las Comunidades Partidistas." Enlace Zapatista, Febrero 21. Retrieved July 20, 2017, 
2017 (http://enlacezapatista.ezln.org.mx/2016/02/21/y-mientras-tanto-en-lascomunidades-partidistas/).

EZLN. 2016b. "Y en las Comunidades Zapatistas?" Enlace Zapatista, Febrero 23. Retrieved July 07, 2017, 2017 (http://enlacezapatista.ezln.org.mx/2016/02/23/yen-las-comunidades-zapatistas/).

EZLN. 2015. El Pensamiento Crítico Frente a la Hidra Capitalista, Vol. 1, edited by CIDECI, Ciudad de México, México: CIDECI.

EZLN. 2014a. Gobierno Autónomo II. Chiapas, México: EZLN.

EZLN. 2014b. Gobierno Autónomo I. Chiapas, México: EZLN.

EZLN. 2014c. Participación de las Mujeres en el Gobierno Autónomo. Chiapas, México: EZLN.

EZLN. 2014d. Resistencia Autonóma. Chiapas, México: EZLN.

EZLN. 2012. "Did You Listen?" Enlace Zapatista January 1. Retrieved May 28, 2017 (http://enlacezapatista.ezln.org.mx/2013/01/02/communique-of-the-clandestineindigenous-revolutionary-committee-general-command-of-the-zapatista-nationalliberation-army-mexico/).

EZLN. 2005. "Sixth Declaration of the Selva Lacandona." Enlace Zapatista, Junio 12. Retrieved November 28, 2017 (http://enlacezapatista.ezln.org.mx/sdsl-en/).

EZLN. 2003, "Chiapas: La Treceava Estela." Komanilel Julio 13. Retrieved November 15, 2017 (http://komanilel.org/BIBLIOTECA_VIRTUAL/treceava_estela.pdf).

EZLN. 2001. "Comandanta Esther in the Congress of the Union." Schools for Chiapas, March 21. Retrieved May 282017 (http://schoolsforchiapas.org/wpcontent/uploads/2014/03/Comandanta-Esther-in-the-Congress-of-the-Union.pdf).

EZLN. 1994a, "First Declaration of the Lacandona Jungle." Schools for Chiapas, January 1. Retrieved May 12, 2017 (http://schoolsforchiapas.org/wpcontent/uploads/2014/03/1st-Declaration-of-the-Lacandona-Jungle.pdf).

EZLN. 1994b. "Ley Agraria Revolutionaria." CEDOZ, January 1. Retrieved May 12th, 2017 (http://www.cedoz.org/site/content.php?doc=1044\&cat=74 - 5).

EZLN. 1994c. Zapatista Women's Revolutionary Laws. Schools for Chiapas, January 1.

Retrieved June 32017 (http://schoolsforchiapas.org/wpcontent/uploads/2014/03/Zapatista-Womens-Revolutionary-Laws.pdf).

FAO. 2017. "About Right to Food." Retrieved November 20, 2017

(http://www.fao.org/righttofood/about-right-to-food/en/).

FAO. 2011. "Climate Change and Food Security in the Context of the Cancun Agreements." Retrieved November 2, 2017

(https://unfccc.int/resource/docs/2011/smsn/igo/121.pdf).

FAO. 2010. "The Second Report on the State of the World's Plant Genetic Resources for Food and Agriculture." Retrieved October 2, 2017

(http://www.fao.org/docrep/013/i1500e/i1500e00.htm)

Favre, Henri, and Elsa Frost. 1973. Cambio y Continuidad entre los Mayas de México: Contribución al Estudio de la Situación Colonialista en América Latina. Ciudad de México, Mexico: Siglo XXI.

Fitting, Elizabeth. 2011. The Struggle for Maize. Durham, NC: Duke University Press. 
Fletcher, Robert, Wolfram H. Dressler, Zachary R. Anderson, and Bram Büscher. 2018. "Natural Capital Must Be Defended: Green Growth as Neoliberal Biopolitics." The Journal of Peasant Studies. doi: 10.1080/03066150.2018.1428953.

Food \& Water Watch. 2013. Biotech Ambassadors. How the U.S. State Department Promotes the Seed Industry's Global Agenda. Washington D.C.: Food \& Water Watch. Retrieved July 29, 2017

(https://www.foodandwaterwatch.org/sites/default/files/Biotech\%20Ambassadors \%20Report\%20May\%202013.pdf).

Forbis, Melissa. 2011. "Autonomía y un Puñado de Hierbas. La Disputa por las Identidades de Género y Étnicas por Medio del Sanar." Pp. 371-407, in Luchas "Muy Otras." Zapatismo y Autonomía en las Comunidades Indígenas de Chiapas, edited by Bruno Baronnet, Mariana Mora Bayo, Richard Stahler-Sholk. Ciudad de México, México: UAM-Xochimilco, CIESAS, UACH.

Ford, Anabel, and Ronald Nigh. 2009. "Origins of the Maya Forest Garden: Maya

Resource Management." Journal of Ethnobiology 29(2):213-236.

Friedmann, Harriet. 2016. "Commentary: Food Regime Analysis and Agrarian Questions: Widening the Conversation." The Journal of Peasant Studies 43(3):671-692. doi: 10.1080/03066150.2016.1146254.

Friedmann, Harriet. 2015. "Agriculture and the Social State: Subsidies or Commons?". Journal of International Law and International Relations 11(2):116-130.

Friedmann, Harriet. 2005. "From Colonialism to Green Capitalism: Social Movements and Emergence of Food Regimes." Pp. 227-264, in New Directions in the Sociology of Global Development, edited by Frederick Buttel, and Philip McMichael. San Diego, CA: ELSEVIER.

Friedmann, Harriet, and Philip McMichael. 1989. "Agriculture and the State System: the Rise and Decline of National Agricultures, 1870 to the Present." Sociologia Ruralis 29(2):93-117.

GAP, Grupo de Apoyo Pastoral. 2015. Grupo de Apoyo Pastoral para el Seguimiento de los Procesos de la Pastoral de la Madre Tierra. Chiapas, México.

García de León, Antonio. 2002. Resitencia y Utopía. Memorial de Agravios y Crónica de Revueltas y Profecías Acaecidas en la Provincia de Chiapas. Ciudad de México, México: ERA.

García de León, Antonio. 1995. "La Vuelta del Katún. Chiapas: a Veinte Años del Primer Congreso Indígena." Chiapas 1(Enero). Retrieved November 2010, 2017 (http://www.revistachiapas.org/No1/ch1leon.html).

Gilly, Adolfo. 2001. El Cardenismo: Una Utopía Mexicana. Ciudad de México, México: ERA.

Gilly, Adolfo. 1994. La Revolución Interrumpida. Ciudad de México, México: ERA.

Gilly, Adolfo. (1971) 2015. "Tres Concepciones de la Revolución Mexicana (1971)." Pp. 67-84 in Antología del Pensamiento Crítico Mexicano Contemporáneo, edited by Elvira Concheiro, Alejandro González, Aldo Guevara, Jaime Ortega, y Víctor Pacheco. Argentina: CLACSO. 
Glassman, Jim. 2006. "Primitive Accumulation, Accumulation by Dispossession, Accumulation by 'Extra-Economic' Means." Progress in Human Geography 30(5):608-625. doi: 10.1177/0309132506070172

GLP Profiles. 2017. "March against Monsanto: Once Grassroots Movement Now Big Business, Angry Moms Target GMOs, Vaccines, Chemicals." Genetic Literacy Project. Retrieved December 9, 2017 (https://geneticliteracyproject.org/glpfacts/march-against-monsanto/).

GMWATCH. 2017. "Two Thousand People March against Monsanto and Syngenta in Switzerland." Retrieved December 9, 2017

(http://www.gmwatch.org/en/news/latest-news/17638-two-thousand-peoplemarch-against-monsanto-and-syngenta-in-switzerland).

Gobierno de Mexico. 2017. "Prospera Montos de Apoyos Enero a Junio 2017." Retrieved October 28, 2017 (https://www.gob.mx/cms/uploads/attachment/file/206673/MONTOS_MENSUA LES PRIMER SEMESTRE 2017.pdf).

Gobierno de Mexico. 2007. Ley Federal de Producción, Certificación y Comercio de Semillas. Congreso de la Unión, Junio 15. Retrieved September 302015 (http://www.diputados.gob.mx/LeyesBiblio/pdf/LFPCCS.pdf).

Golay, Christiphe. 2016. "The Right to Seeds and Intellectual Property Rights." Report for United Nations Human Rights Council. May 19. Retrieved October 24, 2017 (https://defendingpeasantrights.files.wordpress.com/2016/11/legal-analysis-rightto-seeds-and-iprs-c-golay.pdf).

Goldman, Michael. 2005. Imperial Nature: The World Bank and Struggles for Social Justice in the Age of Globalization. New Haven: Yale University Press.

Gollin, Douglas, Casper Worm Hansen, and Asger Wingender. 2016. Two Blades of Grass: The Impact of the Green Revolution. Oxford: Centre for the Study of African Economies, University of Oxford.

Gómez, Alberto. 2009. "Prefacio." Pp. 7-8 in Las Semillas del Hambre: Illegalizar la Memoria Campesina, edited by CECCAM. Ciudad de México, México: CECCAM.

Gómez Martínez, Emanuel. 2016. Maíz, Milpa, Milperos y Agricultura Campesina en Chiapas. Ciudad de México, México: Universidad Autónoma Metropolitana. González, Yussel. 2016. "Café de México: una Industria Golpeada." Expansion. Retrieved October 29, 2017 (http://expansion.mx/economia/2016/07/26/la-royaenfermedad-que-golpea-al-cafe-en-mexico).

González-Ortega, E., A. Piñeyro-Nelson, E. Gómez-Hernández, E. MonterrubioVázquez, M. Arleo, J. Dávila-Velderrain, C. Martínez-Debat, and E.R. ÁlvarezBuylla. 2017. "Pervasive Presence of Transgenes and Glyphosate in MaizeDerived Food in Mexico." Agroecology and Sustainable Food Systems 41(910):1146-1161.

GRAIN. 2013. "Resistance to GMOs in Mexico. Hands off our Maize!" May 16, 2013. Retrieved October 9, 2017 (https://www.grain.org/article/entries/4725-hands-offour-maize-resistance-to-gmos-in-mexico). 
GRAIN. 2009. "La Nueva Ley de Semillas de México." Pp. 15-28 in Las Semillas del Hambre: Illegalizar la Memoria Campesina, edited by CECCAM. Ciudad de México, México: CECCAM.

GRAIN, and La Vía Campesina. 2015. "Seed Laws That Criminalise Farmers." April 8. Retrieved April 2, 2018 (https://www.grain.org/article/entries/5142-seed-lawsthat-criminalise-farmers-resistance-and-fightback).

Guerra, François-Xavier. 1985. Le Mexique de L'ancien Régime a la Révolution. Paris: Editions L'Harmattan.

Gunderson, Christopher. 2018. "Cycles of Accumulation, Cycles of Struggle: The Zapatista Revolt in World-Systemic Perspective." Critical Sociology:1-15. doi: $10.1177 / 0896920517745116$.

Hardin, Garrett. 1978. "Political Requirements for Preserving Our Common Heritage." Pp. 310-17 in Wildlife and America, edited by H. Bokaw. Washington, D.C.: Council of Environmental Quality.

Hardin, Garrett. 1968. "The Tragedy of the Commons." Science 162:1243-1248.

Harvey, David. 2014. Seventeen Contradictions and the End of Capitalism. London: Profile Books LTD.

Harvey, David. 2011. "The Future of the Commons." Radical History Review 2011(109):101-107.

Harvey, David. 2005. A Brief History of Neoliberalism. New York: Oxford University Press.

Harvey, David. 2004. "The 'New' Imperialism: Accumulation by Dispossession." Socialist Register 40: 63-87.

Harvey, David. 2003. The New Imperialism. New York: Oxford University Press. Harvey, Neil. 1998. The Chiapas Rebellion. Durham, NC: Duke University Press. Heat, John Richard. 1990. Enhancing the Contribution of Land Reform to Mexican Agricultural Development. Report for the World Bank. New York: World Bank. Retrieved October 15, 2017

(http://documents.worldbank.org/curated/en/869711468776991462/Enhancingthe-contribution-of-land-reform-to-Mexican-agricultural-development).

Henderson, Thomas Paul. 2016. "State-Peasant Movement Relations and the Politics of Food Sovereignty in Mexico and Ecuador." Journal of Peasant Studies:1-23. doi: http://dx.doi.org/10.1080/03066150.2016.1236024.

Henríquez, Elio. 2017. "María de Jesús Patricio, Candidata de CNI-EZLN a la Presidencia." La Jornada, Mayo 29. Retrieved: May 292017 (http://www.jornada.unam.mx/2017/05/29/politica/005n1pol).

Hewitt de Alcantara, Cynthia. 1976. Modernizing Mexican Agriculture: Socioeconomic Implications of Technological Change 1940-1970. Geneva: United Nations Research Institute for Social Development (UNRISD).

Homer-Dixon, Thomas. 1995. "Environmental Scarcity and Violent Conflict: The Case of Chiapas, Mexico." Retrieved July 272017

(https://homerdixon.com/environmental-scarcity-and-violent-conflict-the-case-ofchiapas-mexico/). 
IARC, International Agency for Research on Cancer. 2017. "Some Organophosphate Insecticides and Herbicides." IARC Monographs. Vol. 112. Lyon, France: World Health Organization.

IICA, Instituto Interamericano de Cooperación para la Agricultura. 2012. Atlas De Propiedad Social y Servicios Ambientales En México. Gobierno de México. Retrieved June 12, 2017

(http://www.ccmss.org.mx/descargas/Atlas_de_propiedad_social_y_servicios_am bientales_en_Mexico.pdf).

IICA. 2012a. Potencial de Servicios Ambientales en la Propiedad Social de México. Gobierno de México. Retrieved June 12, 2017 , (http://www.ccmss.org.mx/descargas/Potencial_de_servicios_ambientales_en_la_ propiedad_social_en_Mexico.PDF).

INEGI, Instituto Nacional de Estadística y Geografía 2016. Estadísticas a Propósito del Día Internacional de los Pueblos Indígenas. Gobierno de México. Ciudad de México, México: INEGI.

INEGI. 2010. Censo de Población y Vivienda. Gobierno de México. Ciudad de México, México: INEGI.

Jaffee, Daniel 2014. Brewing Justice: Fair Trade Coffee, Sustainability, and Survival. Oakland, CA: University of California Press.

Jaffee, Daniel, and Soren Newman. 2013. "A More Perfect Commodity: Bottled Water, Global Accumulation, and Local Contestation." Rural Sociology 78(1):1-28.

Katz, Friedrich. 1974. "Labor Conditions on Haciendas in Porfirian Mexico: Some Trends and Tendencies." The Hispanic American Historical Review 54(1):1-47.

Kelland, Kate. 2017. "Cancer Agency Left in the Dark over Glyphosate Evidence." Reuters, June 14. Retrieved October 29, 2017 (https://www.reuters.com/article/usglyphosate-cancer-data-specialreport/special-report-cancer-agency-left-in-thedark-over-glyphosate-evidence-idUSKBN1951VZ).

Khadse, Ashlesha, and Peter Rosset. 2017. "Scaling up Agroecological Approaches." Pp. 243-58 in Agroecology, Ecosystems and Sustainability in the Tropics, edited by G. Poyyamoli. New Delhi: Studera Press.

Klein, Hilary. 2015. Compañeras: Zapatista Women's Stories. New York: Seven Stories Kloppenburg, Jack. 2014. "Re-Purposing the Master's Tools: The Open Source Seed Initiative and the Struggle for Seed Sovereignty." The Journal of Peasant Studies 41(6):1225-1246.

Kloppenburg, Jack. 2010. "Impeding Dispossession, Enabling Repossession: Biological Open Source and the Recovery of Seed Sovereignty." Journal of Agrarian Change 10(3):367-388.

Kloppenburg, Jack. 2004. First the Seed. The Political Economy of Plant Biotechnology. Madison, WI: University of Wisconsin Press.

Koman Ilel. 2012. "Movilización Zapatista 21 de Diciembre de 2012." Retrieved: May 28, 2017 (http://komanilel.org/2012/12/24/movilizacion-zapatista-21-dediciembre-de-2012/).

Kuper, Adam. 2003. "The Return of the Native." Current Antropology 44(3): 389-402. 
La Jornada del Campo. 2015a. "Geneticamente Alterados." La Jornada, Vol. 98, Noviembre 20. Retrieved January 6, 2017 (http://www.jornada.unam.mx/2015/11/21/delcampo.html).

La Jornada del Campo. 2015b. "Fallo Favorable a Apicultores vs Soya Transgénica Garantiza el Derecho a la Consulta pero Soslaya el Tema Ambiental." La Jornada, Noviembre 21. Retrieved October 16, 2017 (http://www.jornada.unam.mx/2015/11/21/cam-fallo.html).

Lappé, Frances 2011. Diet for a Hot Planet: The Climate Crisis at the End of Your Fork and What Can You Do About It. New York: Bloomsbury

Lappé, Frances, and Joseph Collins 2015. World Hunger. 10 Myths. New York: Food First Books.

Las Abejas. 1997. "La Masacre de Acteal." Retrieved: May 29, 2017 (http://acteal.blogspot.com/p/la-masacre-de-acteal.html).

Lawrence, Deborah, Paolo D’Odorico, Lucy Diekmann, Marcia DeLonge, Rishiraj Das, and James Eaton. 2007. "Ecological Feedbacks Following Deforestation Create the Potential for a Catastrophic Ecosystem Shift in Tropical Dry Forest." PNAS 105(8):20696-20701.

Le Bot, Yvon. 1997. El Sueño Zapatista. Barcelona, España: Plaza \& Janés.

Leal, Juan Felipe. 1984. México: Estado, Burocracia y Sindicalismo. Ciudad de México, México: Ediciones El Caballito.

Leal, Juan Felipe. 1974. La Burguesía y el Estado Mexicano. Ciudad de México, México: Ediciones El Caballito.

Lerna Rodríguez, Enriqueta 2015. "La Pastoral de la Madre Tierra en Chiapas. Panorámica de la Lucha Persistente de un Credo Político-Religioso." Revista Iberoamericana de Teología XI(21):65-88.

Lesperance, Andrea. 2017. "Lessons from Mexico to Canada: GM Crops as Threats to Indigenous Ways of Life." ABS Canada. Retrieved October 162017 (https://www.abs-canada.org/uncategorized/lessons-from-mexico-to-canada-gmcrops-as-threats-to-indigenous-ways-of-life/).

Leyva Solano, Xochitl, and Gabriel Ascencio Franco. 1996. Lacandona al Filo del Agua. Ciudad de México, México: CIESAS, UNAM, FCE.

Lomnitz-Adler, Claudio. 2004. "The Depreciation of Life During Mexico City's Transition into "the Crisis"." Pp. 47-70 in Wounded Cities, edited by Jane Schneider, and Ida Susser. New York: Berg.

López Intzín, Juan. 2013. "Ich’el Ta Muk': La Trama en la Construcción Mutua y Equitativa del Lekil Kuxlejal (Vida Plena-Digna-Justa)." Pp. 18-40 in SentiPensar el Género: Perspectivas desde los Pueblos Originarios, edited by Georgina Méndez Torres, Juan López Intzín, Sylvia Marcos, and Carmen Osorio Hernández. Jalisco, México: Red-IINPIM, Red de Feminismos Descoloniales, and La Casa del Mago.

Louwaars, Niels, Walter Boef, and Janet Edeme. 2013. "Integrated Seed Sector Development in Africa: A Basis for Seed Policy and Law." Journal of Crop Improvement 27(2):186-214. 
Lowenhaupt Tsing, Anna. 2015. The Mushroom at the End of the World: On the Possibility of Life in Capitalist Ruins. Princenton, NJ: Princenton University Press.

Luxemburg, Rosa. 1913. The Accumulation of Capital. London: Routledge and Kegan Paul LTD.

LVC, La Vía Campesina. 2018a, "Food Sovereignty.” Retrieved March 20, 2018 (https://viacampesina.org/en/).

LVC. 2018b. "The International Peasant's Voice." Retrieved March 6, 2018 (https://viacampesina.org/en/international-peasants-voice/).

LVC. 2017, "Agroecology Is Not Just About How We Work with the Land, but Also About How We Work with Each Other as People: Peasant Youth of La Via Campesina." Retrieved March 17, 2018 (https://viacampesina.org/en/agroecology-not-just-work-land-but-also-about-wework-as-people/).

LVC. 2016. "16th October: For People's Food Sovereignty and against Transnational Corporations." Retrieved Dec. 16, 2016 (https://viacampesina.org/en/index.php/main-issues-mainmenu-27/foodsovereignty-and-trade-mainmenu-38/2156-16th-october-for-peoples-foodsovereignty-and-against-transnational-corporations).

LVC. 2013. "La Via Campesina: Our Seeds, Our Future." Retrieved March 17, 2018 (https://viacampesina.org/en/wp-content/uploads/sites/2/2013/06/ENnotebook6.pdf).

MacLeod, Dag. 2004. Downsizing the State: Privatization and the Limits of Neoliberal Reform in Mexico. State College: Pennsylvania University Press.

MAM, March Against Monsanto. 2018. "March Against Monsanto." Retrieved March 17, 2018 (https://www.march-against-monsanto.com/home/).

MAM. 2017. "MAM Flyer B 2017." Retrieved March 17, 2018 (https://www.marchagainst-monsanto.com/flyer/).

Mamdani, Mahmood. 2001. When Victims Become Killers. Colonialism, Nativism, and the Genocide in Rwanda. Princenton, NY: Princenton University Press.

Martínez-Torres, Maria Elena, and Peter Rosset. 2010. "La Via Campesina: The Birth and Evolution of a Transnational Social Movement." The Journal of Peasant Studies 37(1):149-175. doi: 10.1080/03066150903498804.

Marx, Karl. 2015. Capital: Critique of Political Economy. Vol. I. Book One: The Process of Production of Capital. Moscow, USSR: Progress Publishers,.

McCune, Nils, Francisco Guevara-Hernández, Jose Nahed-Toral, Paula Mendoza-Nazar, Jesus Ovando-Cruz, Benigno Ruiz-Sesma, and Leopoldo Medina-Sanson. 2012. "Social-Ecological Resilience and Maize Farming in Chiapas, Mexico." Pp. 485512 in Sustainable Development. Authoritative and Leading Edge Content for Environment Management, edited by Sime Curkovic: INTECH.

McKay, Ben, Ryan Nehring, and Marigold Walsh-Diley. 2014. "The 'State' of Food Sovereignty in Latin America: Political Projects and Alternative Pathways in Venezuela, Ecuador and Bolivia." Journal of Peasant Studies 41(6):1175-1200. 
McMichael, Philip. 2016a. "Commentary: Food Regime for Thought." The Journal of Peasant Studies 43(3):648-670. doi: 10.1080/03066150.2016.1143816.

McMichael, Philip. 2016b. Development and Social Change. A Global Perspective. 5th Edition. Los Angeles: SAGE.

McMichael, Phillip. 2014. "Historicizing Food Sovereignty." The Journal of Peasant Studies 41(6):933-957. doi: 10.1080/03066150.2013.876999.

McMichael, Philip. 2013. Food Regimes and Agrarian Questions. Halifax, NS: Fernwood.

McMichael, Philip. 2012. "The Land Grab and Corporate Food Regime Restructuring." The Journal of Peasant Studies 39(3-4):681-701. doi: 10.1080/03066150.2012.661369

McMichael, Phillip. 2010. "Agrofuels in the Food Regime." Journal of Peasant Studies 37(2010):609-629.

McMichael, Philip. 2009. "A Food Regime Genealogy." Journal of Peasant Studies 36(1):139-169.

McMichael, Philip. 2005. "Global Development and the Corporate Food Regime." Pp. 265-99 in New Directions in the Sociology of Global Development, edited by Frederick Buttel, and Philip McMichael. San Diego, CA: ELSEVIER.

Mercer, Kristin, and Hugo R. Perales. 2010. "Evolutionary Response of Landraces to Climate Change in Centers of Crop Diversity." Evolutionary Applications 3(56):405-584. doi: 10.1111/j.1752-4571.2010.00137.x.

Mercer, Kristin L., Hugo R. Perales, and Joel D. Wainwright. 2012. "Climate Change and the Transgenic Adaptation Strategy: Smallholder Livelihoods, Climate Justice, and Maize Landraces in Mexico." Global Environment Change 22(2):495-504. doi: 10.1016/j.gloenvcha.2012.01.003.

Meyer, Jean. 1986. "Haciendas y Ranchos, Peones y Campesinos en el Porfiriato. Algunas Falacias Estadísticas." Historia de Mexico XXXV(3):477-509.

Migration News. 1995. "Mexico: Immigration and Nafta." Migration News 2(11). Retrieved November 92017 (https://migration.ucdavis.edu/mn/more.php?id=789).

Molina, Marta. 2013. "Lessons in Organization and Dignity from the Zapatistas." Waging Non Violence, January 3. Retrieved November 8, 2017 (https://wagingnonviolence.org/feature/lesson-in-organization-and-presencefrom-the-zapatistas/).

Moore, Jason W. 2015. Capitalism in the Web of Life: Ecology and the Accumulation of Capital. New York: Verso.

Moore, Jason W. 2012. "Cheap Food and Bad Money: Food, Frontiers, and Financialization in the Rise and Demise of Neoliberalism." Review 33(2/3):225261.

Moore, Jason W. 2010. "The End of the Road? Agricultural Revolutions in the Capitalist World-Ecology, 1450-2010." Journal of Agrarian Change 10(3):389-413.

Morales, Mariana. 2016. "La Empresa Monsanto ya Produce en Chiapas 12 mil Hectáreas de Soya Transgénica," El Heraldo de Chiapas, Marzo 3. Retrieved November 2, 
2017 (https://viaorganica.org/la-empresa-monsanto-ya-produce-en-chiapas-12mil-hectareas-de-soya-transgenica/).

Nations, James, and Ronald Nigh. 1980. "The Evolutionary Potential of Lacandon Maya Sustained-Yield Tropical Forest Agriculture." Journal of Anthropological Research 36(1):1-30.

Navdanya. 2018a. "Navdanya". Retrieved March 17, 2018 (http://www.navdanya.org/site/index.php).

Navdanya. 2018b. "What Is Agroecology?" Retrieved March 17, 2018 (http://www.navdanya.org/site/2017-03-29-08-02-10/what-is-agroecology).

Naylor, Lindsay B. 2014. "Decolonial Autonomies: Fair Trade, Subsistence and the Everyday Practice of Food Sovereignty in the Highlands of Chiapas." Ph.D. Dissertation, Department of Geography, University of Oregon.

Nigh, Ronald. 2002. "Maya Medicine in the Biological Gaze." Current Anthropology 43(3):451-477.

Nigh, Ronald, and Stewart Diemont. 2013. "The Maya Milpa: Fire and the Legacy of Living Soil." Frontiers in Ecology and the Environment 11:e45-e54.

OCA, Organic Consumer Association. 2004, "Zapatistas Launch Campaign against Genetically Engineered Corn." Retrieved October 22, 2017 (https://www.organicconsumers.org/old_articles/chiapas/zapatistas050404.php).

Ochoa-Gaona, Susana, and Mario González-Espinosa. 1999. "Land Use and Deforestation in the Highlands of Chiapas, Mexico." Applied Geography 20(2000):17-42.

Offe, Claus. 1996. Modernity and the State. Basingstoke, UK: Palgrave.

Olesen, Thomas. 2005. International Zapatismo: The Construction of Solidarity in the Age of Globalization. NY: Zed Books.

Olson, Mancur. 1965. The Logic of Collective Action. Public Goods and the Theory of Groups. Cambridge, Mass: Harvard University Press.

OSSI, Open Source Seed Initiative. 2018. "Open Source Seed Initiative." Retrieved March 17, 2018 (https://osseeds.org/).

OSSI. 2018. "FAQs". Retrieved April 7, 2018 (https://osseeds.org/faqs/).

Orgambides, Fernando. 1992. "México llega al Primer Mundo. Unanimidad sobre los Efectos Positivos del Tratado de Libre Comercio." El País, Agosto 13. Retrieved January, 10, 2018 (https://elpais.com/diario/1992/08/13/economia/713656802_850215.html).

Ostrom, Elinor. 1990. Governing the Commons. The Evolution of Institutions for Collective Action. Cambridge, U.K.: Cambridge University Press.

Otero, Gerardo. 2012a. "The Neoliberal Food Regime in Latin America: State, Agribusiness Transnational Corporations and Biotechnology." Canadian Journal of Development Studies 33(3):282-294.

Otros Mundos Chiapas. 2013. "Jornada Mundial Contra Monsanto y el Maíz Transgénico en Chiapas." Mayo 23. Retrieved October 18, 2017 (http://otrosmundoschiapas.org/index.php/temas-analisis/43extractivismo/agroindustria/transgenicos/1488-jornada-mundial-contra-monsantoy-el-maiz-transgenico-en-chiapas). 
Paz, Octavio. 1994. "El Nudo de Chiapas." El País, Enero 7. Retrieved February 20, 2018 (https://elpais.com/diario/1994/01/07/opinion/757897210_850215.html)

Pechlaner, Gabriela, and Gerardo Otero. 2010. "The Neoliberal Food Regime: Neoregulation and the New Division of Labor in North America." Rural Sociology 75(2):179-208. doi: 10.1111/j.1549-0831.2009.00006.x

Perales, Hugo. 2016. "Landrace Conservation of Maize in Mexico: An Evolutionary Breeding Interpretation." Pp. 271-281 in Enhancing Crop Genepool Use: Capturing Wild Relative and Landrace Diversity for Crop Improvement edited by N. Maxted, Ehsan Dulloo, and Brian Ford-Lloyd. Oxford UK: CABI.

Perales, Hugo, and Duncan Golicher. 2014. "Mapping the Diversity of Maize Races in Mexico." Plos One 9(12):1-20.

Perales, Hugo, Bruce Benz, and Stephen Brush. 2005. "Maize Diversity and Ethnolinguistic Diversity in Chiapas, Mexico." PNAS 102(3):949-954.

Perales, Hugo, B. Brush, C. Qualset. 2003a. "Landraces of Maize in Central Mexico: An Altitudinal Transect." Economic Botany 57(1):1-20.

Perales, Hugo, B. Brush, O. Qualset. 2003b. "Dynamic Management of Maize Landraces in Central Mexico." Economic Botany 57(1):21-34.

Perales, Hugo, S. B. Brush, C. O. Qualset. 1998. "Agronomic and Economic Competitiveness of Maize Landraces and in Situ Conservation in Mexico." Pp. 109-126 in Farmers, Gene Banks and Crop Breeding: Economic Analyses of Diversity in Wheat, Maize, and Rice., edited by Melinda Smale. Springer. doi: 10.1007/978-94-009-0011-0.

Peters, May, Suchada Langley, and Paul Westcott. 2009. "Agricultural Commodity Price Spikes in the 1970s and 1990s: Valuable Lessons for Today." United States

Department of Agriculture, March 1. Retrieved September 15, 2017 (https://www.ers.usda.gov/amber-waves/2009/march/agricultural-commodityprice-spikes-in-the-1970s-and-1990s-valuable-lessons-for-today/).

Pietrowsli, Alex. 2016. "Victory in Mexico: Indigenous Activists Win Major Court Rulings against Monsanto," True Activist, August 23. Retrieved October 16, 2017 (http://www.trueactivist.com/victory-in-mexico-indigenous-activists-win-majorcourt-rulings-against-monsanto/).

Pimbert, Michel. 2009. Towards Food Sovereignty. London, UK: IIED.

Piñeyro-Nelson, A., J. van Herwaarden, H. Perales, J. Serratos-Hernández, A. Rangel, M. Hufford, P. Gepts, A. Garay-Arroyo, R. Rivera-Bustamante, and E. ÁlvarezBuylla. 2009. "Transgenes in Mexican Maize: Molecular Evidence and Methodological Considerations for GMO Detection in Landrace Populations." Molecular Ecology 18(4):750-761. doi: 10.1111/j.1365-294X.2008.03993.x.

Piperno, Dolores, Anthony Ranere, Irene Holst, Jose Iriarte, and Ruth Dickau. 2009. "Starch Grain and Phytolith Evidence for Early Ninth Millennium B.P. Maize from the Central Balsas River Valley, Mexico." PNAS 106(13):5019-5024.

Polanyi, Karl. 1944. The Great Transformation. The Political and Economic Origins of Our Time. Boston: Beacon, Press.

Poniatowska, Elena. 1971. La Noche De Tlatelolco. Ciudad de México, México: Ediciones Era. 
Pons, Carlos. 2012. Seeds of Transition: Voice of the Wind.

(http://www.lavozdelviento.org/).

Pritchard, Bill, Jane Dixon, Elizabett Hull, and Chetan Choithani. 2016. "'Stepping Back and Moving In': The Role of the State in the Contemporary Food Regime." The Journal of Peasant Studies 43(3):693-710.

Quist, David, and Ignacio H. Chapela. 2001. "Transgenic DNA Introgressed into Traditional Maize Landraces in Oaxaca, Mexico." Nature 414(6863):541-543.

Radel, Claudia, Birgit Schmook, Jamie Mcevoy, Crisol Mendez, and Peggy Petrzelka. 2012. "Labour Migration and Gendered Agricultural Relations: The Feminization of Agriculture in the Ejidal Sector of Calakmul, Mexico." Journal of Agrarian Change 12(1):98-119.

Ramírez Cuevas, Jesus. 2007. "La Masacre de Acteal, Culminación de una Política de Estado Contra Indígenas." La Jornada, Deciembre 22. Retrieved: May 29, 2017 (http://www.jornada.unam.mx/2007/12/22/index.php?article=007n1pol\&section= politica).

Réseau, Semences Paysannes. 2011. Seeds and Farmers' Rights. How International Regulations Affect Farmer Seeds. Aiguillon, France: Réseau Semences Paysannes.

Reyes Ramos, María Eugenia. 1992. El Reparto de Tierras y la Política Agraria en Chiapas, 1914-1988. Ciudad de México, México: UNAM.

Ríos González, Adriana. 2013. "Uso de Modelos Predictivos y Conceptuales para la Evaluación Ambiental y el Análisis de la Percepción de Riesgo por Uso de Plaguicidas: Una Opción para el Manejo de Riesgos en Chiapas." Tesis de Doctorado, Departamento de Ciencias en Ecología y Desarrollo Sustentable, Ecosur, Chiapas.

Rivera, Ramírez F., and A. Contreras Corral. 2015. "Cambios en las Características Sociodemograficas y Económicas de los Hogares Rurales de México: 20022007." Pp. 57-91 in La Economia del Campo Mexicano: Tendencias y Retos Para su Desarrollo., edited by A. Yuñez-Naude, F. Rivera Ramírez, M.A. Chevez Alvarado, J.J. Mora Rivera y J.E. Taylor. Ciudad de México, México COLMEX.

Roberts, Elizabeth. 2017. "Report: Mexico Was Second Deadliest Country in 2016." CNN, May 10. Retrieved February 4, 2018 (https://www.cnn.com/2017/05/09/americas/mexico-second-deadliest-conflict2016/index.html).

Ronfeldt, David, John Arquilla, Graham E. Fuller, and Melissa Fuller. 1998. The Zapatista Social Netwar in Mexico. Santa Monica, CA: RAND.

Ros, Jaime. 1993. Mexico's Trade and Industrialization Experience since 1960: A Reconsideration of Past Policies and Assessment of Current Reform. Working Paper 186 for the Kellogg Institute.

Rosenzweig, Fernando. 1960. "Las Exportaciones Mexicanas de 1877 a 1911." El Trimestre Económico 27(108):537-551.

Rosset, Peter, and Maria Elena Martinez-Torres. 2012. "Rural Social Movements and Agroecology: Context, Theory and Process." Ecology and Society 17(3):17-29. 
Rosset, Peter, Braulio Machín Sosa, Adilén María Roque Jaime, and Dana Rocío Ávila Lozano. 2011. "The Campesino-to-Campesino Agroecology Movement of Anap in Cuba: Social Process Methodology in the Construction of Sustainable Peasant Agriculture and Food Sovereignty." The Journal of Peasant Studies 38(1):161191.

Rosset, Peter, Maria Elena Matinez-Torres, and Luis Hernández-Navarro 2005. "Zapatismo in the Movement of Movements." Development 48(2):35-41.

RT News. 2017. "World Stands up Against Monsanto: Over 400 Cities Protest Gmos," May 24. Retrieved December 9, 2017 (https://www.rt.com/news/261573monsanto-global-protests-gmo/).

Ruiz García, Samuel. 2006. Cómo Me Conviertieron los Indígenas. Ciudad de México, México: SERAPAZ and Frayba.

Rus, Jan. 2012. El Ocaso de las Fincas y la Transformación de la Sociedad Indígena de Los Altos de Chiapas 1974-2009. Tuxtla, México: UNICACH.

Rus, Jan. 2003. "Coffee and the Recolonization of Highland Chiapas, Mexico: Indian Communities and Plantation Labor, 1892-1910." Pp. 257-85 in The Global Coffee Economy in Africa, Asia and Latin America, edited by William Gervase ClaranseSmith, and Steven Topik. New York: Cambridge University Press.

Rus, Jan. 1994. "The Comunidad Revolucionaria Institucional: The Subversion of Native Government in Highland Chiapas, 1936-1968." Pp. 265-300 in Everyday Forms of State Formation:Revolution and the Negotiation of Rule in Modern Mexico, edited by Gilbert M. Joseph. Durham, NC: Duke University Press.

Salinas de Gortari, Carlos. 1994. "El Discurso Inicial de Salinas Frente Al EZLN." Aristegui Noticias, Diciembre 30. Retrieved February 27, 2018 (https://aristeguinoticias.com/3012/mexico/video-el-discurso-inicial-de-salinasfrente-al-ezln/).

Salinas de Gortari, Carlos. 1992. "Discurso de Carlos Salinas de Gortari con Motivo de la Culminación del TLC: Tratado de Libre Comercio México-Estados UnidosCanadá". Retrieved January, 10, 2018

(https://es.wikisource.org/wiki/Discurso_de_Carlos_Salinas_de_Gortari_con_mot ivo de la culminaci\%C3\%B3n del TLC: Tratado de Libre Comercio M\%C3 \%A9xico-Estados_Unidos-Canad\%C3\%A1).

Sanahuja, Jose Antonio. 2000. "Trade, Politics, and Democratization: The 1977 Global Agreement Between the European Union and Mexico." Journal of Interamerican Studies and World Affairs. 42(2): 35-62.

Sanderson, Steven E. 1981. Agrarian Populismo and the Mexican State: The Struggle for Land in Sonora. Berkeley: University of California Press.

Sanderson, Susan Walsh. 1984. Land Reform in Mexico: 1910-1980. Orlando, Florida: Academic Press.

Santiago, Jorge. 2016a. La Pasión de Servir al Pueblo. Entrevista a Jtatic Samuel. San Cristóbal de las Casas, México: Editorial Fray Bartolomé de las Casas.

Santiago, Jorge. 2016b. "El Congreso Indígena de 1974: Buscando Nuestras Raíces," Ojarasca, La Jornada, Mayo. Retrieved November 10, 2017 
(http://ojarasca.jornada.com.mx/2016/05/13/rogelio-cuellar-imagenes-de-uncongreso-historico-5011.html).

Santiago, Jorge. 1999. La Búsqueda de la Libertad: Entrevista a Samuel Ruiz. Chiapas, México: Editorial Fray Bartolomé de las Casas.

Sassen, Saskia. 2014. Expulsions: Brutality and Complexity in the Global Economy. Cambridge: Harvard University Press.

Saxe-Fernández, John. 2002. La Compra-Venta De México. Ciudad de México: Pláza \& Janés.

Saxe-Fernández, John, and Gian Carlo Delgado. 2001. Banco Mundial y Desnacionalización Integral en México. Ciudad de México, México: UNAMCEIICH.

Saxe-Fernández, John, and Omar Núñez Rodríguez. 2001. "Globalización e Imperialism: La Transferencia de Excedentes de América Latina." Pp. 87-166 in Globalización, Imperialism y Clase Social, edited by John Saxe-Fernández, James Petras, Henry Veltmeyer, and Omar Núñez. Buenos Aires, Argentina: LUMEN.

Schatan, Jacobo. 1998. El Saqueo De América Latina: Deuda Externa, Neoliberalismo y Globalización. Santiago de Chile, Chile: LOM and CENDA.

Schiavoni, Christina. 2016. "The Contested Terrain of Food Sovereignty Construction: Toward a Historical, Relational and Interactive Approach." The Journal of Peasant Studies 44(1): 1-32. doi 10.1080/03066150.2016.1234455.

Schmook, Birgit. 2010. "Shifting Maize Cultivation and Secondary Vegetation in the Southern Yucatan: Successional Forest Impacts of Temporal Intensification." Regional Environment Change 10(3):233-246.

Schools for Chiapas. 2017. "GMO-Free Zapatista Seed Corn." Retrieved December 2, 2017 (http://www.schoolsforchiapas.org/store/coffee-corn-and-agricultural/gmofree-zapatista-seed-corn/).

Schurman, Rachel, and William A. Munro. 2010. Fighting for the Future of Food: Activists Versus Agribusiness in the Struggle over Biotechnology. Minneapolis: University of Minnesota Press.

Semple, Kirk. 2017. "Mexico Ready to Play the Corn Card in Trade Talks," The New York Times, April 2. Retrieved October 18, 2017 (https://www.nytimes.com/2017/04/02/world/americas/mexico-corn-naftatrade.html?emc $=$ eta1\&_r=0).

SENASICA, Servicio Nacional de Sanidad, Inocuidad y Calidad Agroalimentaria. 2013. "Situación Epidemiológica de la Roya del Cafeto en México." Gobierno de México, SAGARPA. Retrieved October 24, 2017 (http://www.infocafes.com/descargas/biblioteca/244.pdf).

Shiva, Vandana. 2018. "Seed Sovereigty, " Lexicon of Food. Retrieved March 19, 2018 (https://www.lexiconoffood.com/seeds-and-grains/seed-sovereignty).

Shiva, Vandana. 2017. "The Seeds of Suicide: How Monsanto Destroys Farming," Global Research, February 27. Retrieved January 18, 2018 (https://www.globalresearch.ca/the-seeds-of-suicide-how-monsanto-destroysfarming/5329947). 
Shiva, Vandana. 2016. Who Really Feeds the World? The Failures of Agribusiness and the Promise of Agroecology. Berkeley, CA: North Atlantic Books.

Shiva, Vandana. 2009. "La Ley de Semillas y la ley de Patentes de la India: Sembrando las Semillas de la Dictadura." Pp. 107-32 in Las Semillas del Hambre: Illegalizar la Memoria Campesina, edited by CECCAM. Ciudad de México, México: CECCAM.

Shiva, Vandana. 2005. Earth Democracy: Justice, Sustainability, and Peace. Berkeley, CA: North Atlantic Books.

Shiva, Vandana. 1991. The Violence of Green Revolution. Third World Agriculture, Ecology and Politics. Penang, Malasya: Jutaprint.

Shotwell, Alexis. 2016. Against Purity: Living Ethically in Compromised Times. Minneapolis: University of Minnesota Press.

Siegel, Taggart, and Jon Betz. 2016. Seed. The Untold Story. (https://www.seedthemovie.com/).

Silva, Vera, Luca Montanarella, Arwyn Jones, Oihane Fernández-Ugalde, Hans G. J. Mol, Coen J. Ritsema, and Violette Geissen. 2017. "Distribution of Glyphosate and Aminomethylphosphonic Acid (Ampa) in Agricultural Topsoils of the European Union." Science of the Total Environment. 621:1352-1359. doi: 10.1016?.j.scitotenv.2017.10.093.

Sin Maíz No Hay País. 2008. "Campaña Nacional en Defensa de la Soberanía Alimentaria y la Reactivación del Campo Mexicano Sin Maíz No Hay País y Sin Frijol Tampoco ¡Pon a México En Tu Boca!" Retrieved October 18, 2017 (http://sinmaiznohaypais.org/quienes-somos-la-campana).

Smith, Adam. 1776. An Inquiry into the Nature and Causes of the Wealth of Nations Chicago: The University of Chicago Press.

Smith, Robert. 1981. "Resolving the Tragedy of the Commons by Creating Private Property Rights in Wildlife." CATO Journal 1:439-468.

Snapp, Sieglinde, and Barry Pound. 2017. Agricultural Systems. Agroecology and Rural Innovation for Development. Burlington, MA: Elsevier.

Sotelo, Paz Clara Elizabeth. 2017. "El Parentesco en la Transmisión de Semillas Campesinasen Las Margaritas, Chiapas." Tesis de Maestría, Departamento de Agroecología, ECOSUR, Chiapas, México.

Starr, Amory, María Elena Martínez-Torres, and Peter Rosset. 2011. "Participatory Democracy in Action: Practices of the Zapatistas and the Movimento Sem Terra." Latin American Perspectives 38(1)(176):102-119.

Stavenhagen, Rodolfo. 2013. The Emergence of Indigenous Peoples. Springer. eBook ISBN: 978-3-642-34144-1.

Strom, Stephanie. 2015. "Many G.M.O.-Free Labels, Little Clarity over Rules," New York Times, January 30. Retrieved February 19, 2018 (https://www.nytimes.com/2015/01/31/business/gmo-labels-for-food-are-in-highdemand-but-provide-little-certainty.html).

Tamariz, Gabriel. 2013. "GM Crops vs. Apiculture. An Ecological Distribution Conflict in the Mayan Region of Mexico." Tesis Master, Institut de Ciència i Tecnologia Ambientals, ICTA, , Autonomous University of Barcelona. 
Tannenbaum, Frank. 1929. The Mexican Agrarian Revolution. New York: Macmillan. The Guardian. 2016. "Glyphosate Unlikely to Pose Risk to Humans, UN/WHO Study Says," The Guardian, May 16. Retrieved October 29, 2017

(https://www.theguardian.com/environment/2016/may/16/glyphosate-unlikely-topose-risk-to-humans-unwho-study-says).

Thompson, Roberto, María del Carmen García Aguilar, and Mario Castillo Huerta. 1988. Crecimiento y Desarrollo Económico en Chiapas, 1982-1988: Cambio Estructural en Chiapas. Chiapas, Mexico: UNIACH.

Tinoco-Ojanguren, Rolando, and David C. Halperin 2010. "Poverty, Production, and Health: Inhibition of Erythrocyte Cholinesterase Via Occupational Exposure to Organophosphate Insecticides in Chiapas, Mexico." Archives of Environmental Health: An International Journal 53(1):29-35.

Turner, John Kenneth. 1910. Barbarous Mexico. Chicago: Charles H. Kerr \& Company. U.K. Government. 2018. "Farm Saved Seed." September 7. Retrieved April 7, 2018 (https://www.gov.uk/guidance/farm-saved-seed).

U.S. Grains Council. 2017. "Corn Production and Exports." U.S. Grains Council. Retrieved October 27, 2017 (http://www.grains.org/buyingselling/corn).

UN, United Nations, Human Rights Office of the High Commissioner. 2017, "Special Rapporteur on the Right to Food." Retrieved October 16, 2017 (http://www.ohchr.org/EN/Issues/Food/Pages/FoodIndex.aspx).

UN, United Nations, Human Rights Office of the High Commissioner. 2012. Estudio Sobre los Desplazados por el Conflicto Armado en Chiapas. Ciudad de México, México: United Nations.

UN-Millenium, Ecosystem Assessment 2005. Ecosystems and Human Well-Being: Synthesis. Washington D.C.,: Island Press.

UNDP, United Nations Development Program. 2015. Índice De Desarrollo Humano Para Las Entidades Federativas, México 2015. Ciudad de México, México: PNUD.

UNDP. 2014. Índice de Desarrollo Humano Municipal en México. Ciudad de México, México: PNUD.

Ureta, Carolina, Enrique Martínez-Meyer, Hugo R. Perales, and Elena R. Álvarez-Buylla. 2012. "Projecting the Effects of Climate Change on the Distribution of Maize Races and Their Wild Relatives in Mexico." Global Change Biology 18(3):19731082. doi: 10.1111/j.1365-2486.2011.02607.x.

USDA. 2017. "Adoption of Genetically Engineered Crops in the U.S.." United States Department of Agriculture. Retrieved October 4, 2017 (https://www.ers.usda.gov/data-products/adoption-of-genetically-engineeredcrops-in-the-us.aspx).

Vail, John. 2010. "Decommodification and Egalitarian Political Economy." Politics and Society 38(3):310-346.

van der Ploeg, Jan Douwe 2010. "The Peasantries of the Twenty-First Century: The Commoditisation Debate Revisited." The Journal of Peasant Studies 37(1):1-30. doi: 10.1080/03066150903498721. 
van der Haar, Gemma. 2007. "Land Reform, the State, and the Zapatista Uprising in Chiapas." The Journal of Peasant Studies 32(3-4):484-507.

Veltmeyer, Henry, and James Petras. 2008. "Peasants in an Era of Neoliberal Globalization: Latin America on the Move." Theomai 18(2): 4-29.

Veltmeyer, Henry, and James Petras. 1997. Neoliberalism and Class in Latin America. New York: Steve Vieux.

Villafuerte Solís, Daniel., S. Meza Díaz, G. Ascencio Franco, M.C. García Aguilar, C. Rivera Farfán, M. Lisbona Guillén, and J. Morales Bermúdez. 1999. La Tierra en Chiapas: Viejos Problemas Nuevos. Ciudad de México: Fondo de Cultura Económica.

Villanueva-Gutiérrez, R., C. Echazarreta-González, D. W. Roubick, and B. MoguelOrdóñez. 2014. "Transgenic Soybean Pollen (Glycine Max L.) in Honey from the Yucatán Peninsula, Mexico." Scientific Reports 4(4022):1-4.

Voces Feministas. 2017. "María de Jesús Patricio Candidata Presidencial del EZLN para el 2018." Retrieved: May 282017

(https://vocesfeministas.com/2017/05/28/maria-jesus-patricio-candidata-ezln/).

Wasserstrom, Robert. 1977. "Land and Labour in Central Chiapas: A Regional Analysis." Development and Change 8(4):441-463.

Wattnem, Tamara. 2016. "Seed Laws, Certification and Standardization: Outlawing Informal Seed Systems in the Global South." The Journal of Peasant Studies 43(4): 850-867. doi: 10.1080/03066150.2015.1130702.

Weis, Tony. 2013. The Ecological Hoofprint. The Global Burden of Industrial Livestock. London, U.K.: Zed Books.

White, Ben, and Anirban Dasgupta. 2010. "Agrofuels Capitalism: A View from Political Economy." Journal of Peasant Studies 37(4):593-607.

Wild, Nettie. 1998. A Place Called Chiapas. YouTube Website (https://www.youtube.com/watch?v=m9cuC1Cex0s).

Wilkes, Garrison. 2004. "Corn, Strange and Marvelous: But Is a Definitive Origin Known?" Pp. 3-63 in Corn. Origin, History, Technology, and Production, edited by Wayne Smith, Javier Betrán, and E. C. A Runge. Hoboken, NJ: Wiley.

Wise, Timothy. 2009. "Agricultural Dumping under Nafta: Estimating the Costs of U.S. Agricultural Policies to Mexican Producers." Mexican Rural Development Research Projects. Vol. 7. Washington D.C., Washington, DC: Woodrow Wilson Center for International Scholars.

Wittman, Hannah, Annette Aurelie Desmarais, and Nettie Wiebe. 2010. Food Sovereignty. Reconnecting Food, Nature and Community. Oakland, CA: Food First Books.

Wolf, Eric. 1959. Sons of the Shaking Earth. Chicago: University of Chicago Press.

Wolf, Eric 1956. "Aspects of Group Relations in a Complex Society: Mexico." American Anthropologist 58(6):1065-1078.

World Bank. 1988. "Loan Agreement (Agricultural Sector Loan) between International Bank for Reconstruction and Development and Nacional Financiera, S.N.C.." World Bank. 
World Bank. 1991. "Report and Recomendation of the International Bank for Reconstruction and Development to the Executive Directors on a Proposed Agricultural Sector Adjustment Loan Ii in an Amount Eqivalent to Us $\$ 400$ Millions to Nacional Financiera S.N.C. With the Guaratee of Te United Mexican States." World Bank.

World Bank. 1994. "Project Completion Report. Mexico. Agricultural Sector Adjustment Loan." World Bank.

Wright, Erik Olin. 2010. "The Tasks of Emancipatory Social Science." Pp. 10-29 in Envisioning Real Utopias. London: Verso

Yuñez-Naude, Antonio. 2003. "The Dismantling of Conasupo, a Mexican State Trader in Agriculture." The World Economy 26(1):97-122.

Zaga, Daniel 2015. "Masked Development: Exploring the Hidden Benefits of Thezapatista Conflict." Working Paper, Graduate Institute of Geneva. Retrieved July 3, 2017

(https://www.researchgate.net/publication/284189004_Masked_Development_Ex ploring_the_Hidden_Benefits_of_the_Zapatista_Conflict).

Zamorano, Varea Paulina. 2001. "Notas sobre la Vida y Desintegracion de la Encomienda. 1700-1720." Cuadernos de Historia 21(Diciembre):37-60. 


\section{APPENDIX: RESEARCH METHODS}

The point of ethnography is to learn how to think about a situation together with one's informants...It takes concrete histories to make any concept come to life.

Anna Lowenhaupt Tsing The Mushroom at the End of the World

Here I reflect on how this ethnographic research was conducted. In the first section I trace the timeline of my fieldwork in Chiapas and discuss the issue of access. The second section presents and discusses the methods used for data collection and data analysis. In an attempt to avoid a dry description of methods, this section also discusses the respondents whose words and ideas are quoted and discussed in this dissertation; a strong emphasis is put on those people whom I consider to be key informants in this research. The third section is a reflection on the methods and some of the limitations of this ethnographic work. In the last section I present a brief discussion on my own positionality and the apparent contradictions that exist between my role as a solidarity activist supporting the Zapatista movement and my role as an independent researcher carrying out an academic study about this indigenous movement.

\section{Research Timeline and Access}

I collaborated with DESMI as a full-time volunteer from August 2015 to March 2016. My main work, as I mentioned in the introduction, was to support DESMI staff with all the activities related to the Guardians of Mother Earth and Seeds project. I attended and documented all the project workshops, meetings, and activities during that period. Being part of DESMI allowed me to have unrestricted access to communities, 
people, and other organizations. I also benefited from being able to travel to many different communities accompanied by people from DESMI, which is an exceptional privilege in a context of low-intensity war.

I can identify four different periods in my collaboration with DESMI:

August-September 2015: The adaptation period. I joined DESMI and began to attend and help systematize the workshops of the Guardians of Mother Earth and Seeds Project. During these months only the most essential information was shared with me and I had to figure out for myself what DESMI was about.

October 2015: The access period. Elena invited me to organize a three-day seed sovereignty workshop with the parish of San Andrés - a potential new member of the project. This workshop was particularly important for two reasons: first, the high number of communities that would participate (about 60); and second, it marked the first time that DESMI had worked with these non-Zapatista communities. All DESMI staff except Elena would participate in the workshop. I had three responsibilities: to coordinate the presentations, to introduce the Guardians of Mother Earth and Seeds project during the workshop, and to write up the documentation of the event. The workshop was a success, and I am sure that this was the moment when I was really granted access to DESMI.

October 2015-March 2016: The immersion period. After the workshop in San Andrés, I was allowed to participate in almost all activities of the organization-in addition to the Guardians of Mother Earth project — and was even invited to visit Zapatista territory. This was the period when I began to have a more comprehensive 
understanding of DESMI's work and its relationships with both Zapatista and nonZapatista communities.

January-March 2016: The formal interview period. During these months I was allowed to carry out formal semistructured interviews with community members and with the staff of other organizations for my own research. Elena connected me with key people from DESMI — including members of DESMI's external consultant board — and other organizations, and allowed me to take time in the office for those interviews. Finally, between February and March, I conducted one last interview with each of the DESMI staff members. My final interview was with Sebastian, DESMI's former director. It was in that interview, which lasted about three hours, that Sebastian recounted for me the story of DESMI since 1969.

In order to complement my work at DESMI, I tried to immerse myself in all possible spaces and activities in San Cristóbal de las Casas that were "open" to those activists willing to approach the EZLN. My previous experiences with the Zapatista movement were crucial for achieving this re-immersion. During my eight-month stay in San Cristóbal, I lived in a relatively well-known community house - a middle-sized house in which 30 or more people sleep in bunk beds and share one small kitchen and three bathrooms - where activists from around the world stay between their visits to Zapatista communities as peace observers for the Frayba Human Rights Center. The daily coexistence with activists allowed me access to information about the low-intensity war conditions that Zapatista communities were experiencing, but also about the organizations these activists belonged to, and the kind of relationship and projects those 
organizations had with the EZLN. I was also able to ask people what motivated them to collaborate with the Zapatista movement, when they had begun visiting Zapatista communities, and what other social movements or social justice issues they were engaged with. These conversations helped me to understand how those international activists perceived the Zapatista movement and what kind of links existed between the EZLN and international NGOs and social movements.

I also attended and participated in most of the political economy seminars and conferences organized by the Cideci - the Zapatista university, which is located in San Cristóbal — and other local organizations. The seminars at the Cideci were an invaluable source of information for my research, because they explicitly aim to complement many of the intellectual discussions that take place among the high ranks of the Zapatista movement. The Cideci is the main space in which the EZLN and civil society reflect on political economy issues such as capital accumulation, war, anti-neoliberal social movements, and anti-capitalist alternatives. For example, it was in the Cideci where the international seminar "Critical Thinking Against the Capitalist Hydra" took place in 2015. The seminars I attended were useful because they allowed me to better understand some of DESMI's projects and its goals, and to contextualize DESMI in relation to the Zapatista movement.

However, it was my friendship with Juan, a Tseltal Zapatista man in his forties and a key informant for this research, which opened up to me an entirely new space in Zapatista communities. Juan not only invited me to his community on a regular basis and allowed me to informally interview members of his family, most of whom held different 
cargos in the Zapatista government - two of them were agroecology promoters from the Oventic Caracol_-but he also introduced me to the cosmovision of indigenous Zapatista communities. Juan is a well-known intellectual from the Oventic region who has extensively written about the indigenous concept Lekil Kuxlejal-Ich'el ta muk' (the process of building a life to be lived in dignity and harmony), a very popular idea in the context of the Zapatista movement (see Chapter 4). I first heard about this concept through him. Juan also introduced me to the Mayan theology and put me in contact with several other practitioners. Juan soon became my main interpreter of the Zapatista world and he helped me to decipher much of the information I gathered during my visits to Zapatista communities with DESMI staff.

There was one more person who became an essential informant for this project: the researcher Hugo Perales, from Ecosur, the regional university. One of the best-known researchers on maize in Mexico, he introduced me to the world of maize and the peasant practices that have allowed its reproduction, conservation, and evolution for millennia. The multiple conversations with Hugo that followed fieldwork were essential to remove my misconceptions about maize, native seeds, and seed sovereignty, and helped me to ground my arguments in empirical facts. Hugo unconditionally shared with me the knowledge he has developed over decades of work with peasant communities in Chiapas. Similar to my first encounter with Elena, having met Juan and Hugo Perales was also a stroke of luck. Aside from community members, then, this research is the outcome of my encounter with five other key actors who opened to me, and helped me to interpret 
and navigate, the world of peasant communities in Chiapas: Elena, Juan, Hugo Perales, DESMI, and the Cideci.

\section{Methods}

This qualitative research incorporates three main components: (1) participant and nonparticipant observation; (2) semistructured interviews with community members, DESMI staff, members of the pastoral of the diocese of San Cristóbal, the staff of other local NGOs, and scholars from public universities and research centers in San Cristóbal; and (3) document analysis.

\section{Participant and Nonparticipant Observation}

As can be deduced from the previous sections, participant and nonparticipant observation was a key component of this ethnographic research. Everyday conversations, informal individual and group interviews (not audio recorded), photographs, and detailed fieldnotes from all kind of activities I engaged in (workshops, meetings, seminars, ceremonies, conferences, family celebrations, and many other daily activities) constitute important sources of empirical data for this dissertation.

Most of the data collection through participant and nonparticipant observation happened in the context of my work with DESMI. The task of collecting data was considerably facilitated - even encouraged — because of my responsibility to document the trajectory of the Guardians of Mother Earth and Seeds project. This role allowed me to take substantial, detailed notes during workshops and meetings, take photographs, ask both peasants and members of the Church pastoral for particular data or clarification of 
information, and carry out group interviews with community members in order to assess the project's objectives, strategies, and outcomes.

This role also facilitated my developing of trustworthy relationships with members of the pastoral, which were essential in order to coordinate workshops among DESMI, the parishes, and communities. These quotidian interactions were extremely useful for approaching the diocese's work and the experiences, motivations, and ideas of the people who make it possible.

Having the freedom to openly collect all these data would simply have been impossible outside of my responsibility to conduct and record this project. Indeed, aside from the 25 communities comprising the Guardians of Mother Earth and Seeds project, I was not allowed to collect such detailed information in any other community. For instance, I could not take photographs or even notes during my visits to Zapatista communities. Neither could I ask people questions that were not strictly related to the projects that concerned our visits. In those cases, I was restricted to carrying out nonparticipant observation. After leaving these Zapatista communities, I would take detailed fieldnotes in order to record the information, ideas, and impressions that had arisen during the visit. In the other non-Zapatista communities that did not participate in the Guardians of Mother Earth and Seeds project, I had much more freedom to interact with people and take notes than in Zapatista communities; however, I was not allowed to take photographs or ask questions that were too specific.

The situation was similar in those Zapatista and non-Zapatista communities I visited with Juan. Because these were more personal visits, many of them in the context 
of family meetings, ceremonies, or celebrations, it would have been inappropriate to take notes and photographs, or ask people for information outside the topics concerning the visit. Detailed fieldnotes constitute the main record of these visits. Later, equipped with my notebook, I would ask Juan for clarifications, interpretations, and more information.

I want to reiterate that Juan helped me to interpret and complement much of the information I gathered from all of the communities during my fieldwork. He was able to answer several of my questions concerning peasant agriculture, communities' spiritual and cultural practices, and many other issues related to the Zapatista movement. Juan is in a unique position not only because he belongs to a Zapatista family and is a practitioner of the Mayan Theology, but also because he is a staff member of one of the most important human rights organization in Chiapas. He is also an intellectual educated in philosophy and a multilingual interpreter who speaks Tseltal (his mother tongue), Tsotsil, and Spanish. In addition to all the information, insight, and experiences that Juan shared with me, he also facilitated my encounter with many people, most of them Zapatistas and/or practitioners of the Mayan theology, whom I would later formally and informally interview (both audio recorded or non-audio recorded).

\section{Semistructured Interviews}

Complementing participant and nonparticipant observation are the 63 semistructured interviews I conducted at the end of my fieldwork. This includes 39 interviews with Zapatista and non-Zapatista community members, 13 interviews with staff members of DESMI and other local organizations and activists, six interviews with active and former members of the pastoral of the diocese of San Cristóbal, and five 
interviews with scholars from public universities and research centers in San Cristóbal: El Colegio de la Frontera Sur (Ecosur), University of Chapingo, and the Center for Studies for Change in the Mexican Countryside (CECCAM).

All of the interviews took place in Chiapas; the specific places were determined by respondents' geographic location. I conducted interviews in communities and parishes, universities, the offices of DESMI's and other organizations, and coffee shops in San Cristóbal. These interviews lasted between 45 minutes and three hours. I personally conducted, digitally recorded, transcribed, and coded all interviews. I also translated into English all the quotes from interviews that are cited in this dissertation. All semistructured interviews were conducted with the sole purpose of collecting data for this dissertation and I did not share the information contained in them with anyone. The only exceptions were two interviews in which the respondents explicitly asked me for a PDF copy of the transcription. Not all of the interviews are cited in this dissertation.

In order to protect informants' identities, pseudonyms were used for all respondents except the five scholars. A similar intention shaped my use of place names: I have identified the names of municipalities instead of individual communities, with the purpose of protecting communities' anonymity and preventing any possible risk.

Following a similar logic, I did not identify any organizations and NGOs other than DESMI.

Because the semistructured interviews took place only at the end of my eight months of fieldwork (from mid-January through the end of March 2016), they enabled me to enhance and give coherence to my previous observations and experiences in the 
field. The interviews allowed me to complement, reiterate, compare, and/or challenge the information I had gathered during the earlier stages of my fieldwork. In other words, semistructured interviews helped me to put together the different pieces of the puzzle and identify and address some of the gaps that had been neglected up to that point.

Moreover, most of these interviews were also a disclosure exercise - a kind of farewell—in which respondents shared with me more comprehensive and confidential stories than those they had told me during our previous and more informal conversations. It is likely that after months of having worked together, respondents felt comfortable telling me "a little more" about their communities, projects, and organizations, and their personal trajectories, desires, and fears. In addition to obtaining information directly related to communities and DESMI, these interviews were invaluable for deepening my understanding of the Zapatista movement and the people who give life to it, and the rich and diverse ways in which non-Zapatista communities and other actors understand and relate with the indigenous movement.

\section{(1) Interviews with Community Members}

At the time I conducted my fieldwork, 25 indigenous and mestizo non-Zapatista communities comprised the Guardians of Mother Earth and Seeds project (see Chapters 3 and 6). I interviewed people and gathered information from all 25 communities. The respondents from indigenous communities were the same people who already had the responsibility of representing their community in the project (communities had assigned between two and four representatives who were obligated to attend all the workshops). The dynamic in the two mestizo communities was different because every workshop was 
carried out inside these communities, which allowed many community members, between 12 and 40 people, to attend the workshops. All of the individual respondents, in both indigenous and mestizo communities, were voluntarily suggested by members of their communities, basically due to their fluency in Spanish. All of the interviews took place in public spaces and in the presence of other community members who corroborated and complemented the information.

The ethnographic chapters of this dissertation are largely focused on these 25 communities. However, I also had the opportunity to visit several other Zapatista and non-Zapatista communities, in the company of DESMI staff and Juan, where I also engaged in participant and non-participant observation, talked to people, carried out informal interviews, and took fieldnotes. The information I gathered in those communities not participating in the Guardians of Mother Earth and Seeds project was invaluable for contextualizing, interpreting, and complementing the information I collected from the 25 communities that were the focus of my ethnographic research. All of the interviews with Zapatista community members that are cited in this dissertation come from those external, non-participating communities. In contrast, the large majority of the quotes from non-Zapatista community members that I include in this dissertation come from the 25 communities that do comprise the Guardians of Mother Earth and Seeds project.

(2) Interviews with Members of the Pastoral of the Diocese of San Cristóbal I conducted a total of six interviews with active and former members of the pastoral. Four of those interviews took place within the framework of the Guardians of 
Mother Earth and Seeds project. These respondents were the same people who were responsible for coordinating DESMI's workshops with the parishes and communities. At the time of the interviews, I had been working with them for several months, which greatly facilitated our conversations. I conducted these interviews a couple of months before the end of my fieldwork, and only after the authorization of Elena (DESMI's director).

I also interviewed two former members of the diocese who had collaborated with DESMI in the 1980s and 1990s while working in peasant communities as members of the pastoral. These two interviews were invaluable for this research because they offered an external recounting of DESMI's story and some of the ways in which this organization has impacted peasant communities. These interviews also offered insight into the relationships between peasant communities in the region and the clandestine guerrilla movement in the Lacandón rainforest. Elena and Sebastian (DESMI's former director) put me in contact with these two respondents.

\section{(3) Interviews with Staff Members of DESMI and Other Local Organizations}

In addition to everyday interactions and long informal conversations with all members of DESMI staff - including the receptionist and the two accountants - I conducted semistructured interviews with all four responsables de area (the people who were responsible for a particular group of communities), as well as Elena, Sebastian, and some other members of the organization's board of external consultants. These semistructured interviews took place at the very end of my fieldwork and they helped me to expand my understanding of particular topics. During these interviews I was able to 
ask very specific questions about the organization — information that I was unable to access to other means_-and about how respondents perceived themselves as part of DESMI and in relation to the Zapatista movement. These interviews complemented, and in some ways culminated, the multiple conversations and informal interviews (nonrecorded) that had taken place during the previous months.

With the help of Elena and Juan I was also able to interview several members of other local organizations. Some of these interviews were not recorded (in accordance with respondents' requests) but I was allowed to take comprehensive notes during the process.

\section{(4) Interviews with Scholars}

In order to complement the universe of peasant communities and the people and organizations working with them, I conducted five interviews with scholars from public universities in San Cristóbal. I first met and interviewed Dr. Bruce Fergurson, from the Department of Agroecology at Ecosur. He recommended that I contact other researchers from Ecosur, the University of Chapingo, and CECCAM, and provided me with their contact information. All of the scholars whom I interviewed conduct research on the topics of food sovereignty, agroecology, and/or native maize. These interviews were particularly useful for contextualizing my case study as a part of broader bodies of scholarship on these topics. These interviews also helped me to interpret information through additional theoretical and conceptual frameworks. The researchers also shared and commented on their own work with me and suggested other studies that could complement my fieldwork. Although all of these interviews were useful, I want to 
emphasize that Hugo Perales, from the Department of Agroecology at Ecosur, has contributed immensely to this research. Countless Skype conversations with him followed our first in-person interview in San Cristóbal, in February 2016, and most of the academic studies on maize that are cited in this dissertation were his recommendation. He also helped me to interpret my data.

\section{Document Analysis}

Another important component of data gathering was collecting relevant documents. I was given access to most of DESMI's documents related to the Guardians of Mother Earth and Seeds project. Considering that the project was new at the time of my arrival at DESMI, there were just a few documents with only the most basic information about the project: the number of communities, objectives and goals, timelines, subprojects, and the names of the international agencies collaborating with the project.

Elena also shared with me the documents DESMI had collected in past years from the pastoral of Mother Earth and the 2014 Diocesan Congress of Mother Earth. I was also allowed access to DESMI's library, which comprises an outstanding collection of books about the contemporary history of Chiapas and the Zapatista movement, in addition to DESMI's historical documents and publications. Although public, most of the documents referenced in this section are difficult to access. For instance, many published books had been discontinued by publishers and bookstores, and public libraries did not hold copies of them. Only few people had collected, organized, and systematized all the documents 
from the Congress of Mother Earth as Elena had, and DESMI's publications were not broadly distributed, making it possible to access them only through its own library.

These documents were invaluable for complementing, triangulating, and interpreting the information I gathered in the field. They were also useful for identifying important topics that I would later address during my interviews. Having access to such diverse historical and contemporary documents allowed me to assemble a broad, rich picture of the contemporary history of Chiapas.

\section{Data Analysis}

Interviews. I fully transcribed all 63 interviews from the audio recordings into Word documents. The transcripts were then coded and indexed to frequently occurring themes and, eventually, to specific sections of the dissertation. I translated from Spanish to English all of the fragments that are used as quotes in this dissertation.

Observation. The fieldnotes gathered through participant and non-participant observation were partially transcribed into a Word document and then coded and indexed according to themes and chapters.

\section{Reflections on Methods and Limitations of Research}

My collaboration with DESMI as a volunteer had substantial benefits for this research. Besides the fundamental fact that DESMI is one of the key actors analyzed in this dissertation, this organization also constituted my main entrée to peasant communities and other local organizations in the region. Traveling across Chiapas, accessing peasant communities and local organizations, and building trustful relationships with people in a context of low-intensity war are considerable challenges 
that any outsider attempting to work or do research in the region has to face. I was extremely fortunate to be able to count on the relationships, networks, and logisticsfrom transportation, to food and accommodation in communities, to security measuresthat DESMI has created and cultivated over almost 50 years of collaboration with peasant communities and other organizations in the region.

Another substantial benefit of having collaborated with DESMI was that I had access to a considerable number of Zapatista and non-Zapatista communities (about 60), to mestizo and indigenous peasants of different ages, genders, and ethnicities, and to the members of other local organizations. Without the support and accompaniment of DESMI staff it would have been impossible to access such a diverse range of actors, settings, and experiences. These diverse sources of information allowed me to analyze the development of these peasant communities at a regional scale and contextualize them in the framework of the contemporary indigenous movement in Chiapas — within which DESMI, the diocese of San Cristóbal, and the EZLN are key actors.

However, the drawback of having had access to so many communities is that this research consequently lacks in-depth, long-term ethnographic fieldwork conducted in individual communities. All of my visits to individual communities only lasted between one and four days - the length of visits was determined by the distance between San Cristóbal and the community — and most of them took place within the framework of DESMI's workshops. The number of times I visited each individual community is uneven and was determined by the logistics of DESMI's work. Several workshops with indigenous communities took place in the parishes (in the case of the theoretical 
workshops) or in one specific community (in the case of the empirical workshops). The communities in which meetings were held rotated from workshop to workshop but DESMI only organized encounters in those communities that were easy to access for all attendees. Therefore, there were several indigenous communities (whose members are represented in the interviews) that I never visited, some communities that I visited only once or twice, and other communities I visited several times.

This limited and uneven access to communities forced me to rely greatly on the information that communities' representatives shared during the workshops or in our interviews. In the case of those communities that I was unable to visit — where physical access would have required walking long distances - I tried to corroborate these representatives' information by asking them similar questions over several different workshops and complementing that information with DESMI's reports from previous visits to those communities. Despite the restrictions that limited physical access to some communities imposed on my research, the benefits of being able to talk with people from those remote communities in other locations greatly surpassed any disadvantage. It would have been simply impossible to talk to them outside the context of DESMI's workshops.

A different situation occurred in the three mestizo communities. Because all workshops were held inside these two communities, I was able to visit them on a regular basis. These visits were greatly facilitated by the fact that mestizo communities are generally located near roads and towns, and reaching them by car is easier than accessing indigenous communities. Moreover, those visits permitted direct observation of all the projects DESMI was contributing to in the community. This allowed me to directly 
corroborate the evolution of community projects such as vegetable gardens, composting, or mushroom production.

In addition to the communities I was able to access through DESMI, there were other communities I visited with Juan, including his own home community. Although these visits were in more intimate settings than DESMI's workshops-family or community events, or religious and spiritual ceremonies - I never spent a single night in those communities. Casual access by outsiders to Zapatista communities is restricted to specific events such as a family lunch, community celebrations, or minor ceremonies. Outsiders cannot spend the night in those communities without proper authorization from the community government.

The lack of ongoing, daily contact with community members and long-term observation inside individual communities prevented me from evaluating how peasants truly perceive their collaboration with DESMI and the effectiveness of specific projects focused on agroecology and food security. Without doubt, this research would have benefited from observing and asking peasants in a quotidian context about how they conceive and relate to the practices of organic agriculture, seed reproduction, and the preservation of the milpa system, among other issues. It would also have been beneficial for this research to hear peasants' opinions about the potentialities of the agroecological model while observing how they balance, on a daily basis, their commitment to organic agriculture — with its concomitant demands of time, labor, and expertise - with the need of households to assure a cash income. 
Finally, another important restriction that limited the gathering of more objective information about how peasants perceive DESMI and its work agenda was my role as a volunteer for DESMI. Community members identified me as a member of DESMI instead of as an "independent" researcher. DESMI encouraged this perception and I was always presented to community members as "a volunteer from Mexico City who will be collaborating with DESMI for some months," in the words of Mariano. Even the semistructured interviews at the end of my fieldwork were carried out under this identity. Having this role was likely a determinant factor influencing the kind of information peasants decided to share with me. However, although this identity could have prevented peasants from sharing more critical ideas, less "polite" or "enthusiastic" evaluations of DESMI's projects, or simply information that they do not consider of concern to DESMI, this identity also protected me from the widespread negative perceptions that communities — and other organizations' members as well— - have about academics such as anthropologists and ethnobotanists whose research contributes little to communities. ${ }^{1}$

As such, although this research lacks the specificity and meticulous detail that indepth, long-term participant and non-participant observation in one single setting would allow, it benefited substantially from a unique and privileged access to a rich diversity of informants, settings, and experiences. This diversity, which was determined by the particular dynamics and logistics of DESMI's work, allowed me to develop a regional case study rich in detail and complexity. This regional fieldwork turned out to be optimal for the study and analysis of organizations such as DESMI, the diocese of San Cristóbal, and the EZLN, whose projects, agendas, and goals transcend individual communities and 
aim to forge regional alliances and working networks. This research is also unique because I had access to an organization that, although almost invisible to outsiders, has substantially contributed to the making of the indigenous movement in Chiapas. This study also makes a valuable contribution to the existing literatures on both the Zapatista movement and on food and seed sovereignty, through an in-depth ethnographic case study based on this privileged access.

\section{A Note on Positionality}

It is impossible to argue that this research is not shaped by my own perceptions and political ideas about the Zapatista movement. I have closely followed this movement since I was 13 years old, and I have embraced as my own many of its precepts related to justice. In several ways, as I mentioned before, this movement has strongly shaped my own understandings about the world and social change. This means that I did not arrive in Chiapas with a detached mind, free of preconceptions that would allow me to objectively approach the subject of study.

In addition to my personal experiences in Zapatista territory—which are limited to several short visits between 1998 and 2002, and then this eight-month ethnographic study between 2015-2016 - there is another important factor that has directly influenced my perceptions about the EZLN. This movement is characterized by its strong and dynamic communication with civil society, which not only means that thousands of people from Mexico and across the world have visited Zapatista territory since 1994, but also that the EZLN has produced literally thousands of communiqués, declarations, essays, and literary stories; there are also several short films, and even a movie (Cortés 2009). To this 
prolific production of documents it is necessary to add the hundreds of books, academic studies, newspaper articles, opinion pieces, documentaries, websites, paintings, and songs that scholars, journalists, activists, and artists have produced in order to support, analyze, or discuss the EZLN. All of these documents can be seen as collectively constituting the record of the movement, a record that has been mainly written by the EZLN and its supporters.

Niels Barmeyer, an anthropologist and pro-Zapatista activist from Germany, notes that this self-portrait, or in his words discourse production, has strongly contributed to the idealization of the Zapatista movement by solidarity activists (2009: 214-236), and, I would add, solidarity scholars too. I am fully aware that this idealized image of the EZLN has strongly shaped my own understanding of the movement, an understanding that until my fieldwork relied much more on those documents- - which I have read, watched, and listened for 24 years now - than on direct experiences in the communities. In his book Developing Zapatista Autonomy (2009), Barmeyer writes a critical reflection about the relationship between the EZLN and solidarity activists that I think is accurate, taking my personal experience as a reference point. Although extensive, it is worth reproducing his ideas here because they reflect my own experiences in the field:

The protagonists of international solidarity have largely ignored these mechanisms of discourse production. A truly heterogeneous multitude, they exhibit a broad spectrum of worldviews and ideologies... But their ideologies do have a common denominator. In my view, this is the notion of the comunidad indigena, which is central to utopian projections of pro-Zapatista solidarity groups 
far and wide. In this imagined community, harmony reigns among the autochthonous inhabitants. Guided by ancient Mayan wisdom, gender equality, and deep respect for their natural environment, it is a matter of course that all their decisions are consensual. As most activists tend to lead lives of individualized city dwellers, an idealized Zapatista commune attracts them. Even if they do not attempt to realize it for themselves, they like the idea of contributing to its existence in that faraway place called Chiapas.

However, today's indigenous communities are historical products of colonialism, of the elites that have exploited their workforce, and last but not least of their inhabitants' own agency...these communities are far from being the primordial entities that many EZLN sympathizers imagine them to be. They are characterized neither by a special harmony among their inhabitants nor by a particular caring attitude toward the nature that surrounds them. Patriarchal structures are all-pervasive and even "consensual decisions" are often the results of undemocratic processes. Privacy and individual liberties that are taken for granted by most EZLN's solidarity activists from North America and Europe are almost nonexistent. Collective work, however, does indeed play an important role. Conflicts between individuals and interest groups are sometimes carried out violently and, contrary to the assumptions of most solidarity activists, political affiliation usually is not static but guided by pragmatism rather than loyalty...organic farming methods have indeed come into use recently to achieve higher yields with little cash input. However, the use of permaculture, nitrogen- 
producing vines, and compost instead of chemical fertilizers often constitutes not traditional knowledge but techniques taught to the campesinos by urban specialists in the context of recent development projects. Absurdly, the very organizations sponsoring such projects refer to imported knowledge such as organic farming methods and the use of certain medicinal plants as indigenous traditions in order to enlist new donors. For the supporters from a technicalized metropolis, the seeming primitiveness of a Zapatista village possesses romantic attraction. For the inhabitants it is a deficiency that needs to be remedied (2009: 220-221).

How do I balance the utopian self-delusion that seems to be inherent to pro-EZLN activists with my responsibilities as an independent, critical scholar? I think that the answer is that I feel more committed to the broader idea that independent, critical research is needed in order to trigger effective social change - a principle of what Erik O. Wright calls emancipatory social science (Wright 2010) — than to the Zapatista movement per se. Moreover, there are also other social movements and activist identities I feel even more committed to than Zapatismo, particularly the feminist, animal rights, and environmental social movements. In that sense, I recognize that although the Zapatista movement has fully embraced the feminist and environmental causes as its own, there are several structural limitations preventing the consolidation of these agendas. The question of animal rights, for example, is almost nonexistent in Zapatista communities, and it is fair to say that in most peasant communities in Mexico, including Zapatista communities, animals are severely mistreated. Can an environmentalist project be successful without 
considering the wellbeing of animals? I believe not. Is it possible to talk about gender equality when women are still in practice denied the right to land, or when girls lag far behind boys in school attendance or food intake? I do not think so.

I am not uncritical of the fact that gender equality and environmental preservation in Zapatista territory are still more an ideological declaration of principles than a solid reality. However, it is true that despite many difficulties - including open confrontations with critical feminists (Klein 2015: 217-255) — the EZLN has not abandoned those agendas and continues to put them at the center of the Zapatista movement. In other words, the fact that gender equality or organic agriculture in the milpa are not yet a concrete reality in Zapatista territory, does not entirely discredit the self-depicted image of the EZLN as a movement working toward gender equality and environmental conservation. Keeping these agendas alive - and more than alive, at the center of the public image of the movement and the multiple organizations working with it, including DESMI - is a permanent challenge that the EZLN imposes on its constituency. After my own experiences in the field, I would say that the EZLN and organizations such as DESMI measure their own achievements and failures in relation to those unfulfilled agendas. Those agendas are also a reminder of the difficult path that the movement has still to walk if it wants to consolidate its autonomous model of indigenous government in the long term.

I would like to conclude this dissertation with a quote by Alexis Shotwell from her book Against Purity: Living Ethically in Compromised Times, which offers an interesting perspective on the work of activists and social movements that outsiders - in 
this case scholars — should keep in mind when evaluating their achievements and failures:

"The point is to change the world, this world, and so the point is complicated, compromised, and impossible to conceptualize, let alone achieve alone. People doing movement work usually get lots of things wrong, which might not be such a problem-if the purpose of the work isn't to be right. Instead, our purpose is to contingently make it be that something that deserves a future has one" (2016: 196). 